UNIVERSIDADE DE BRASÍLIA

FACULDADE DE TECNOLOGIA

DEPARTAMENTO DE ENGENHARIA CIVIL E AMBIENTAL

\title{
CONTROLE DE VAZÕES OUTORGADAS: \\ ESTUDO DE CASO DA BACIA DO SÃO FRANCISCO
}

LEONARDO PERES ARAUJO PIAU

ORIENTADOR: SERGIO KOIDE

DISSERTAÇÃO DE MESTRADO EM TECNOLOGIA AMBIENTAL E RECURSOS HÍDRICOS

PTARH.DM-195/2016

Brasília/DF: DEZEMBRO/2016 
UNIVERSIDADE DE BRASÍLIA

FACULDADE DE TECNOLOGIA

DEPARTAMENTO DE ENGENHARIA CIVIL

CONTROLE DE VAZÕES OUTORGADAS:

ESTUDO DE CASO DA BACIA DO SÃO FRANCISCO

LEONARDO PERES ARAUJO PIAU

DISSERTAÇÃO SUBMETIDA AO DEPARTAMENTO DE ENGENHARIA CIVIL E AMBIENTAL DA FACULDADE DE TECNOLOGIA DA UNIVERSIDADE DE BRASÍLIA COMO PARTE DOS REQUISITOS NECESSÁRIOS PARA A OBTENÇÃO DO GRAU DE MESTRE EM TECNOLOGIA AMBIENTAL E RECURSOS HÍDRICOS.

APROVADA POR:

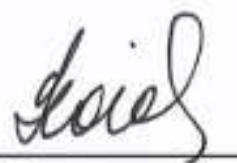

Prof. Sergio Koide, PhD (PTARH-UnB)

(Orientador)
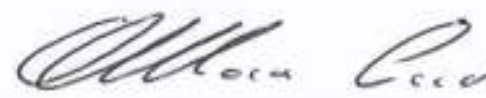

Prof. Oscar de Moraes Cordeiro Netto, Doutor (PTARH -UnB)

(Examinador Interno)

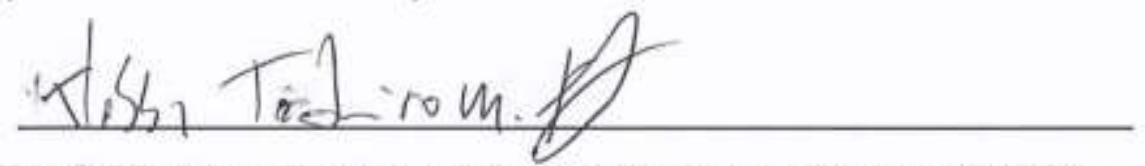

Prof. Klebber Teodoro Martins Formiga, Doutor (UFG)

(Examinador Externo)

BRASÍLIA/DF: DEZEMBRO/2016 


\section{FICHA CATALOGRÁFICA}

PIAU, L.P.A.

CONTROLE DE VAZÕES OUTORGADAS: ESTUDO DE CASO DA BACIA DO SÃO FRANCISCO. xix, 197p., 210 x 297 mm (ENC/FT/ UnB, Mestre, Tecnologia Ambiental e Recursos Hídricos, 2016). Dissertação de Mestrado - Universidade de Brasília. Faculdade de Tecnologia. Departamento de Engenharia Civil e Ambiental.
1. Controle
2. Monitoramento
3. Outorga
4. Sistema de suporte à decisão
I. ENC/FT/UnB
II. Título (série)

\section{REFERÊNCIA BIBLIOGRÁFICA}

PIAU, L.P.A. (2016). Controle das vazões outorgadas: estudo de caso da bacia do São Francisco. Dissertação de Mestrado em Tecnologia Ambiental e Recursos Hídricos, Publicação PTARH.DM-195/2016, Departamento de Engenharia Civil e Ambiental, Universidade de Brasília, Brasília, DF, 197p.

\section{CESSÃO DE DIREITOS}

NOME DO AUTOR: Leonardo Peres Araujo Piau.

TÍTULO: Controle de vazões outorgadas: estudo de caso da bacia do São Francisco

GRAU: Mestre

ANO: 2016

É concedida à Universidade de Brasília permissão para reproduzir cópias desta dissertação de mestrado e para emprestar ou vender tais cópias somente para propósitos acadêmicos e científicos. O autor reserva outros direitos de publicação e nenhuma parte dessa dissertação de mestrado pode ser reproduzida sem autorização por escrito do autor.

\footnotetext{
Leonardo Peres Araujo Piau

Brasília - DF - Brasil.
} 


\section{AGRADECIMENTOS}

A Deus, que me deu a oportunidade de santificar este trabalho, procurando fazê-lo com amor, para glória dEle; de santificar-me neste trabalho, crescendo em virtudes como a humildade, perseverança, paciência e ordem; de santificar os outros com este trabalho, por tê-lo oferecido nas intenções de familiares e amigos.

À Nossa Senhora de Guadalupe; mãe, guia, protetora, refúgio, consoladora, esperança nossa e sede de sabedoria.

À Francine, pela ternura, carinho e dedicação; por ser minha principal motivação para superar todas as dificuldades ao longo destes anos dedicados à dissertação.

A meus filhos, Paloma e Santiago, que me fazem querer ser uma pessoa melhor a cada dia; e ao Chiquinho, meu pequeno que está no céu e cuida de todos nós.

Aos familiares, pais, irmãos, cunhados, sobrinhos e agregados, pela companhia e apoio nos momentos de tristeza e alegria.

Aos amigos, em especial aos "Bancuebas" e aos "Matelitos", a quem pude contar nas horas difíceis e compartilhar os momentos de descontração.

À ANA, pela oportunidade e confiança depositada em minha pessoa, mesmo parecendo improvável o término do trabalho.

Ao Rubens e ao Bruno Collischonn, pela orientação e horas de ajuda no trabalho.

Aos colegas do PTARH, pelo aprendizado e pelo "desespero conjunto", que nos fez unir e tornar possível esse sonho.

Aos professores Oscar e Conceição, pela orientação e luz para trilhar o caminho.

Ao meu orientador, Prof. Koide, a quem muito admiro e estimo. 


\section{RESUMO}

A outorga de direito do uso da água é um instrumento da Política Nacional de Recursos Hídricos que possibilita estimar o consumo de água de forma indireta, mas pode se distanciar do real volume de água requerido pelo usuário de recursos hídricos outorgado. Pelo desenvolvimento deste trabalho, verificou-se que o controle das vazões por parte dos usuários outorgados pode auxiliar o instrumento da outorga a fim de aproximar o mundo legal ao mundo real de consumo, observado em campo. Além disso, atende ao normativo legal de obrigação dos usuários outorgados a realizarem o monitoramento das vazões apropriadas por estes.

Definiu-se uma classificação para o controle do uso de recursos hídricos, a partir de três estágios gradativos de monitoramento a serem exigidos aos usuários outorgados, a saber: monitoramento simplificado, onde o usuário pode adotar os valores de projeto para ter conhecimento do uso outorgado; monitoramento intermediário, em que se define um controle objetivo do tempo de utilização do ponto de interferência outorgado, mediante instalação de um dispositivo acumulador de tempo; e monitoramento avançado, com instalação de equipamento de medição de vazão que possa acumular o volume de água outorgado, além de envio de Declaração Anual de Uso de Recursos Hídricos, com os volumes mensais utilizados. Para chegar à referida classificação, foram criados índices absolutos e relativos para determinar a significância de usuários outorgados nos trechos onde estão localizados, bem como indicadores gerais de bacia para distribuição dos usuários nos três estágios de exigência. Para testar e chegar a valores finais desses índices, foi realizado estudo de caso utilizando dados reais de outorgas na bacia do rio São Francisco.

Em seguida, desenvolveu-se a etapa experimental do trabalho, focada na aquisição, instalação e funcionamento de diversos equipamentos de medição constantes de um projeto-piloto na bacia do ribeirão Pipiripau, com resultados de desempenho, operação, manutenção, vantagens, desvantagens e recomendações gerais de cada um dos equipamentos instalados.

Com os valores dos índices definidos do estudo de caso e os resultados dos equipamentos do estudo experimental, e tomando por base um sistema de suporte à decisão existente para auxílio à outorga, o denominado Sistema de Controle de Balanço Hídrico - SCBH, elaborado por Collischonn (2014), chegou-se nesse trabalho ao desenvolvimento de um fluxograma detalhado, representando um subsistema do SCBH, um "módulo auxiliar" chamado SCBH-Fiscalização. 


\begin{abstract}
Water Resources Use Rights Grant is an instrument of the National Water Resources Policy that enables to estimate the consumption of indirect water, but can distance himself from the real water required volume. Controlling the amount of the water required by users can assist the grant instrument in order to bring the legal world to the real world consumption.
\end{abstract}

The goal in this work was controlling the use of water resources, from three incremental stages of monitoring to be required to granted users: simplified monitoring, where the user can adopt the design values of pump; intermediate monitoring, which set a goal control the usage time of the interference given point by installing a device accumulates pain time; and advanced monitoring, with flow measurement equipment installation that may accumulate the volume of water granted in addition to sending Annual Statement of Use of Water Resources, the monthly volumes used. To get to that classification, it was necessary to create absolute and relative indices to determine the significance of granted users in the sections where they are located, To test and reach the final values of these indices was carried out case study using real data grants in the São Francisco river basin.

The experimental work's stage consisted in the acquisition, installation and operation of several constant measuring equipment of a pilot project in Pipiripau stream basin, with performance results, operation, maintenance, advantages, and disadvantages for each of the installed equipment.

With the values of the indexes defined the case study and the results of the experimental study equipment, and building on an existing decision support system to aid grant, called the Balance Control System Hydride - SCBH, elaborated by Collischonn (2014), was reached in this work to the development of a detailed flow chart, representing a subsystem of SCBH an "auxiliary module" called SCBH-Inspection. 


\section{SUMÁRIO}

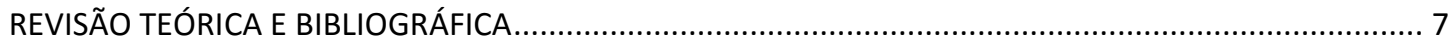

3.1 O USO DE RECURSOS HÍDRICOS E SEU MONITORAMENTO ……............................................. 7

3.1.1 O monitoramento dos recursos hídricos no âmbito legal brasileiro ......................................... 8

3.1.1.1 Exigências da ANA quanto ao monitoramento e medição ..............................................

3.1.1.2 Exigências dos órgãos gestores de recursos hídricos estaduais .....................................11

3.1.2 Dificuldades para normatização do monitoramento............................................................ 14

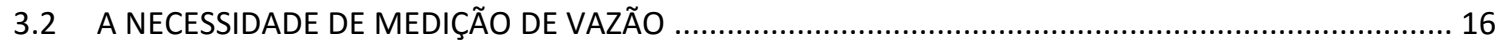

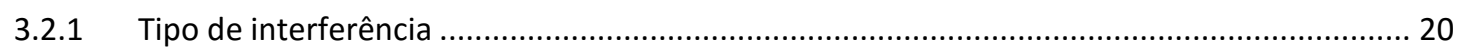

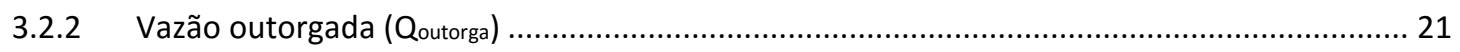

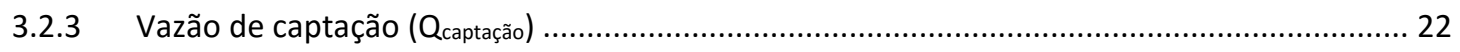

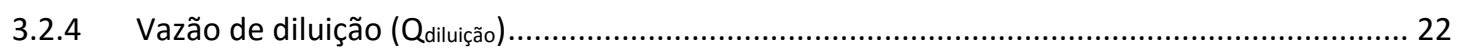

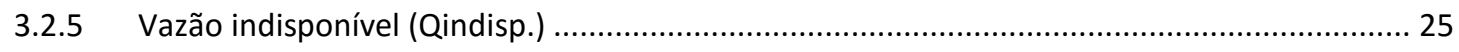

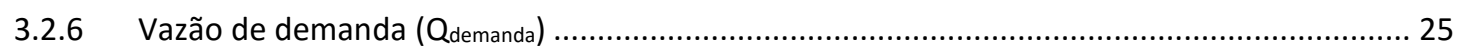

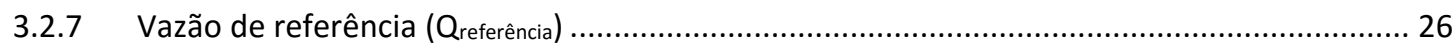

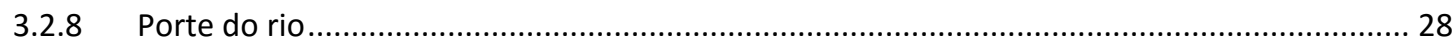

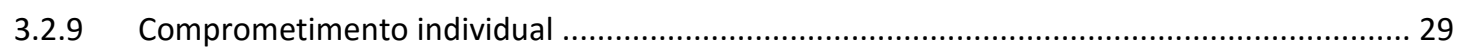

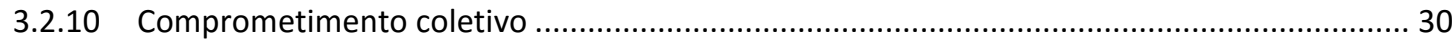

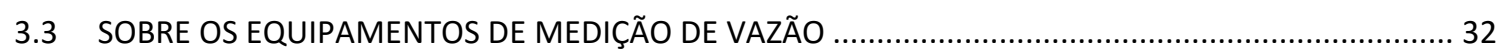

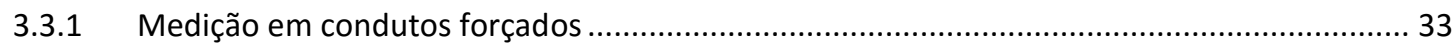

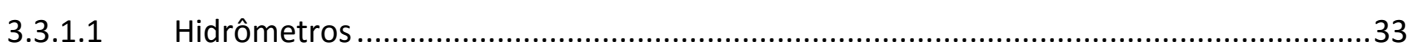

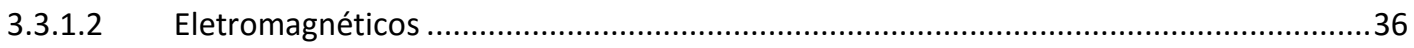

3.3.1.3 Ultrassônicos por tempo de trânsito ………………………………………………......39

3.3.1.4 Diferenciais de pressão ..............................................................................................4

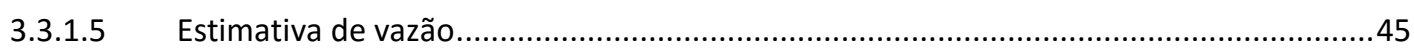

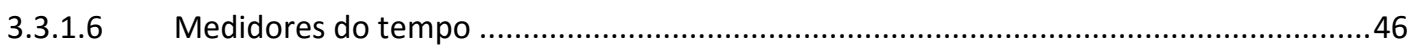

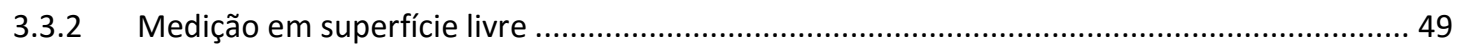

3.3.2.1 Medidor ultrassônico de vazão por Efeito Doppler: ……………………………….....50

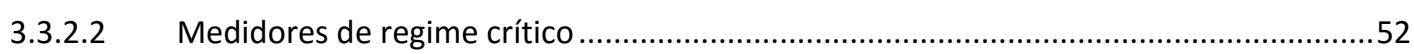

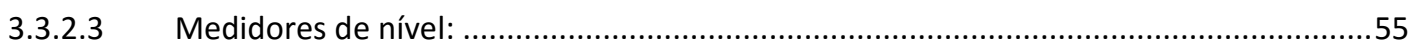



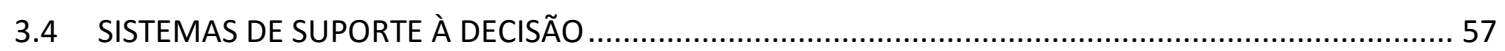

3.4.1 Sistemas de suporte à decisão específicos para a outorga .................................................... 61

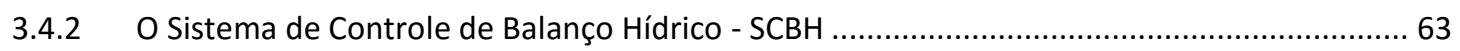






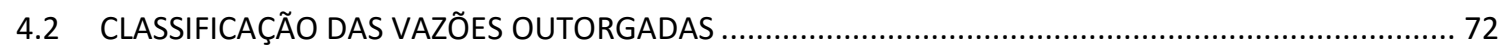



4.4 FLUXOGRAMA PARA POSSIBILITAR CONSTRUÇÃO DE SSD PARA CONTROLE DAS VAZÕES

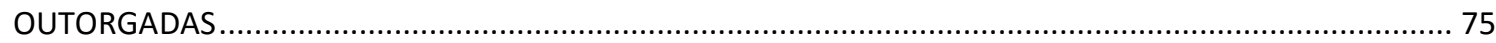

5 RESULTADOS E DISCUSSÃO

5.1 EQUIPAMENTOS DE MEDIÇÃO DE VAZÃO PARA CADA UM DOS NÍVEIS DE MONITORAMENTO

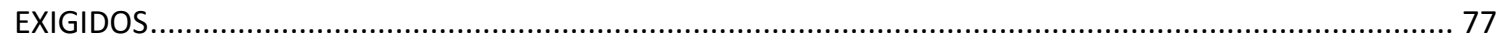

5.2 SISTEMATIZAÇÃO DE PROCEDIMENTOS PARA CLASSIFICAÇÃO DAS VAZÕES OUTORGADAS ........... 78

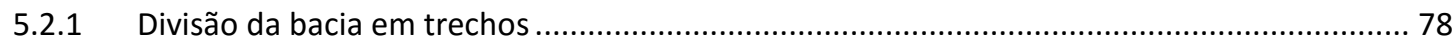

5.2.2 Vazões outorgadas e condições de demanda .................................................................... 78

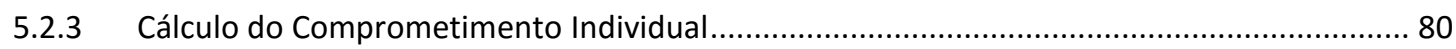

5.2.4 Cálculo do Comprometimento Coletivo ......................................................................... 81

5.2.5 Estabelecimento de níveis de exigência quanto ao monitoramento das vazões outorgadas. 81

5.2.5.1 Nível 1 - Monitoramento simplificado .................................................................. 82

5.2.5.2 Nível 2 - Monitoramento intermediário .....................................................................83

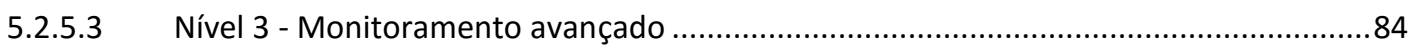

5.2.6 Criação de índices para classificação dos pontos de interferência outorgados ..................... 86

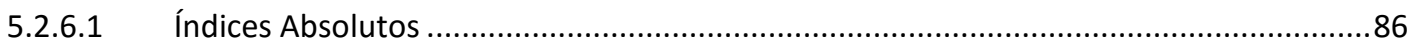

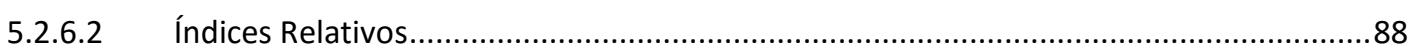

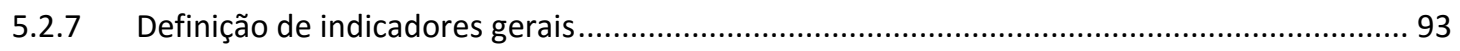

5.2.8 Classificação final dos pontos de interferência .................................................................... 98





5.3.2 Cálculos iniciais: Vazões de Demanda, Comprometimento Individual e Coletivo................. 108

5.3.3 Cálculo dos Índices Absolutos e Relativos ......................................................................... 112

5.3.3.1 Cenário 1: Sem índices absolutos, índices relativos mais restritivos ..........................112

5.3.3.2 Cenário 2: Sem índices absolutos, índices relativos menos restritivos ........................117

5.3.3.3 Cenário 3: Sem índices absolutos, índices relativos intermediários ............................119

5.3.3.4 Cenário 4 - Final: índices relativos intermediários, com índices absolutos.................121

5.3.4 Discussão dos resultados do estudo de caso............................................................... 125

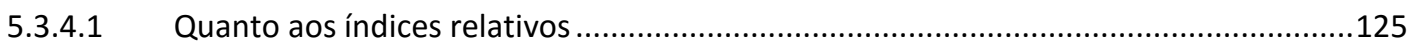

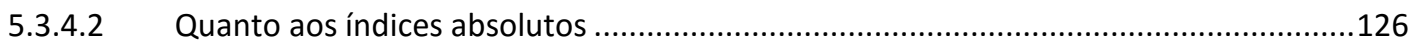

5.3.4.3 Quanto ao estabelecimento de valores únicos dos índices absolutos e relativos ........127

5.4 FLUXOGRAMA PARA POSSIBILITAR CONSTRUÇÃO DE SSD PARA CONTROLE DAS VAZÕES

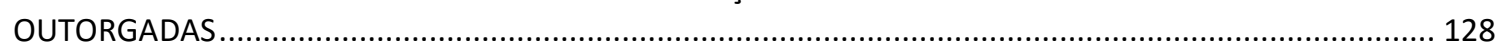

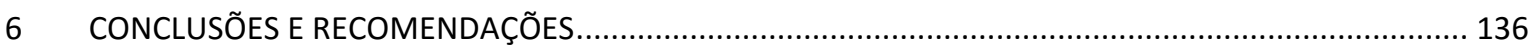

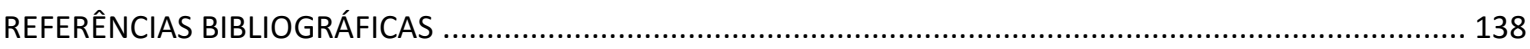


APÊNDICE A - EXIGÊNCIAS LEGAIS DOS ÓRGÃOS GESTORES ESTADUAIS QUANTO AO MONITORAMENTO DA VAZÃO OUTORGADA 147

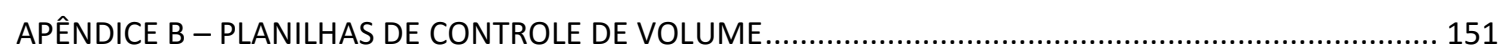

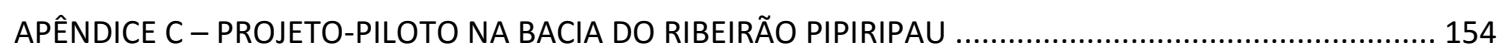



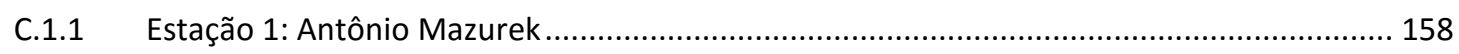

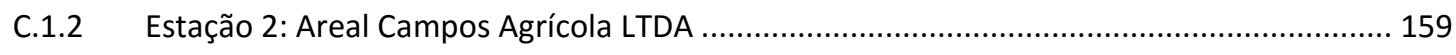

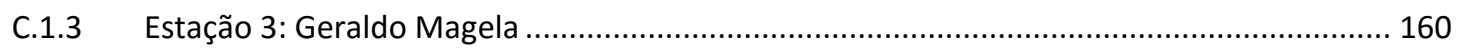

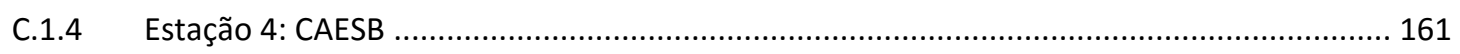

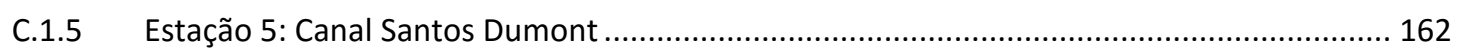

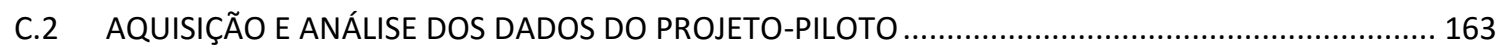

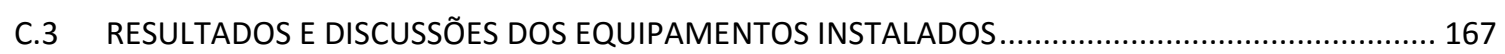

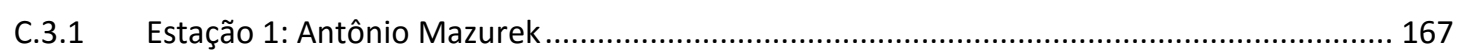



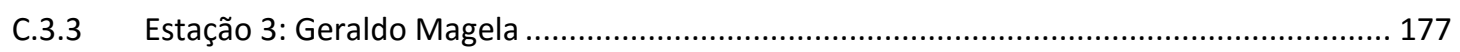



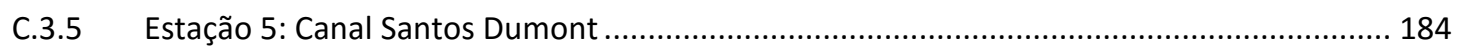

APÊNDICE D - TABELAS RESUMO DOS EQUIPAMENTOS DE MEDIÇÃO DE VAZÃO ………...................... 191 


\section{LISTA DE SÍMBOLOS, NOMECLATURA E ABREVIAÇÕES}

$\Sigma Q_{\text {montante }}$ somatório das vazões outorgadas a montante $\Sigma Q_{\text {demanda_trecho. }}$ somatório das vazões de demanda no trecho considerado $\gamma$ peso específico do fluido v. velocidade Área

ABNT. .Associação Brasileira de Normas Técnicas AC. Acre ADASA .Agência Reguladora de Águas e Saneamento do Distrito Federal AL Alagoas AM. .Amazonas ANA Agência Nacional de Águas AP Amapá

Art. Artigo

BA Bahia

CAESB .Companhia de Saneamento Ambiental do Distrito Federal CE Ceará

CF. .Constituição da República Federativa do Brasil CHESF. .Companhia Hidro Elétrica do São Francisco

CNRH .Conselho Nacional de Recursos Hídricos

COGERH. Companhia de Gestão de Recursos Hídricos do Estado do Ceará CODEVASF.......Companhia de Desenvolvimento dos Vales do São Francisco e do Parnaíba CONAMA. .Conselho Nacional do Meio Ambiente

D. .diâmetro nominal da tubulação

DAURH. ..Declaração Anual de Uso de Recursos Hídricos DBO .Demanda Bioquímica de Oxigênio

$\mathrm{DBO}_{5,20}$ .DBO a uma temperatura média de $20^{\circ} \mathrm{C}$, durante 5 dias

$\mathrm{DBO}_{\text {efluente...... }}$ .DBO tratada (ou não) do efluente doméstico ou industrial

$\mathrm{DBO}_{\text {permitida. }}$ ..DBO permitida para o corpo hídrico, dada pelo seu enquadramento $\mathrm{DBO}_{\text {natural}}$. .DBO do corpo hídrico, em suas condições naturais DF. ..Distrito Federal EMATER. ..Empresa de Assistência Técnica e Extensão Rural ES Espírito Santo 
$\mathrm{H}(\mathrm{ou} h)$ altura

ICC .Indicador de Comprometimento Coletivo ICC $_{\text {máx }}$ .Indicador de Comprometimento Coletivo Máximo

ICI .Indicador de Comprometimento Individual ICI máx .Indicador de Comprometimento Individual Máximo IGAM Instituto Mineiro de Gestão das Águas

INEMA .Instituto do Meio Ambiente e Recursos Hídricos ISO International Organization for Standardization L largura $1 / \mathrm{s}$. litros por segundo $\mathrm{m}$. metro $\mathrm{m}^{3}$ metro cúbico $\mathrm{m}^{3} / \mathrm{h}$ metro cúbico por hora .Maranhão MG Minas Gerais $\mathrm{mg} / \mathrm{l}$ miligramas por litro $\mathrm{mm}$. milímetro monit. monitoramento MS. Mato Grosso do Sul MT. Mato Grosso

$\mathrm{N} 1$ número de pontos de interferência classificados no $1^{\circ}$ estágio

$\mathrm{N} 2$ número de pontos de interferência classificados no $2^{\circ}$ estágio

N3 número de pontos de interferência classificados no $3^{\circ}$ estágio

$\mathrm{N}_{\text {total }}($ ou NT) número de pontos de interferência outorgados em toda a bacia NBR Norma Brasileira P1CI1.......índice de relevância do ICI $_{\text {máx }}$, em trechos de menor comprometimento, $1^{\circ}$ estágio P1CI2.......índice de relevância do ICI $_{\text {máx }}$ em trechos de menor comprometimento, $2^{\circ}$ estágio P2CI1........índice de relevância do $\mathrm{ICI}_{\text {máx }}$, em trechos de maior comprometimento, $1^{\circ}$ estágio P2CI2 ........índice de relevância do ICI $_{\text {máx }}$ em trechos de maior comprometimento, $2^{\circ}$ estágio PA Pará PB .Paraíba 

.índice de relevância do Indicador de Comprometimento Coletivo Máximo

PE. Pernambuco

PI. Piauí

PNRH ..Política Nacional de Recursos Hídricos

PR .Paraná pto. ponto

Q....... vazão

Q1..... .somatório das vazões de demanda dos pontos de interferência do $1^{\circ}$ estágio

Q2. .somatório das vazões de demanda dos pontos de interferência do $2^{\circ}$ estágio

Q3. ..somatório das vazões de demanda dos pontos de interferência do $3^{\circ}$ estágio

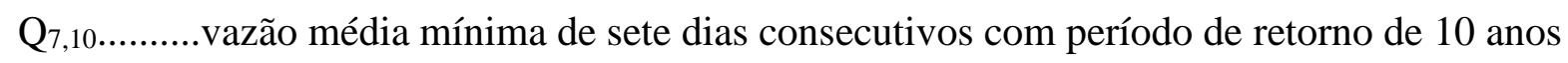
Q90..................vazão com garantia de 90\% de permanência dentro da série histórica de dados Q95..................vazão com garantia de 95\% de permanência dentro da série histórica de dados

Qacumulada..... ..vazão acumulada

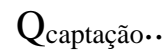
.vazão de captação

$\mathrm{Q}_{\text {demanda }}\left(\right.$ ou $\left.\mathrm{Q}_{\mathrm{dem}}\right)$ vazão de demanda

Q diluição .vazão de diluição

Qefluente...... .vazão de lançamento do efluente doméstico ou industrial Qindisp. ..vazão indisponível

$\mathrm{Q}_{\max }$ .vazão máxima instantânea

Qmáx_outorga. .vazão máxima outorgada

Qmed/dia ..vazão média diária

$\mathrm{Q}_{\text {med/mês }}$ .vazão média mensal

Qoutorga..... .vazão outorgada

Q referência ..vazão de referência

QAB1 .vazão absoluta mínima, $1^{\circ}$ estágio

QAB2 vazão absoluta máxima, $3^{\circ}$ estágio $\mathrm{Q}_{\text {total }}(\mathrm{ou} \mathrm{QT})$.... somatório de todas as vazões de demanda outorgadas na bacia $\mathrm{RJ}$ Rio de Janeiro $\mathrm{RN}$ Rio Grande do Norte

$\mathrm{RO}$ Rondônia

$\mathrm{RR}$ Roraima $\mathrm{R} \$$. preço em reais 

Secretaria do Meio Ambiente e dos Recursos Hídricos do Estado de Goiás tonelada

US\$ preço em dólares V... ..volume 


\section{LISTA DE FIGURAS}

Figura 3.1 - Mapa de classificação das Unidades Federativas do Brasil quanto às exigências legais para monitoramento dos usos outorgados

Figura 3.2 - Medidor velocimétrico tipo Woltmann (esq.), horizontal (meio) ou vertical (dir.) -

Cortesia: FAE Tecnologia

Figura 3.3 - Medidor velocimétrico tipo tangencial ou Woltmann para irrigação (esq.), horizontal (meio) ou vertical (dir.) - Cortesia: Ciasey

Figura 3.4 - Equipamentos eletromagnéticos de inserção (esq.) e carretel (dir.)

Figura 3.5 - Ultrassônico por tempo de trânsito clamp-on (esq.) e intrusivo (dir.) - Cortesia: GE

Panametrics 40

Figura 3.6 - Tubo Pitot (esq.) e Venturi (dir.) - Cortesia: Gustavo Carneiro 42

Figura 3.7 - Placas de orifício: seções transversais (esq.) e longitudinal no fluxo (dir.) - Cortesia: Nilson Taira 44

Figura 3.8 - Bocal de vazão: equipamento (esq.) e longitudinal no fluxo (dir.) - Cortesia: Prestserv 44

Figura 3.9 - Curva característica do sistema (esq.) e da bomba (dir.) - Cortesia: Gustavo Carneiro 45

Figura 3.10 - Ponto de funcionamento ou de operação - Cortesia: Gustavo Carneiro 46

Figura 3.11 - Horímetro analógico (esq.) e digital (dir.) - Cortesia: S\&E Instrumentos. 48

Figura 3.12- Chave de fluxo do tipo palheta (esq.) e pistão (dir.) - Cortesia: Nivetec 49

Figura 3.13- Ultrassônicos tipo Doppler em canais abertos (esq.) e dutos fechados (dir.) - Cortesia: Sontek. 51

Figura 3.14 - Medição a vau com ultrassônicos tipo Doppler (Flowtracker) 51

Figura 3.15 - Medição com ultrassônicos tipo Doppler em canais e rios de médio e grande porte, com embarcação (Acoustic Doppler Current Profiler - ADCP) 51

Figura 3.16 - Calha Parshall instalada (esq.) e calha Palmer-Bowlus (dir.) Cortesia: Inccer. 53

Figura 3.17 - Vertedouro retangular (esq.), triangular (centro) e trapezoidal (dir.) 54

Figura 3.18 - Sensor de pressão hidrostático (esq.), acoplado externamente (centro) ou submerso (dir.) - Cortesia: GE. 55

Figura 3.19 - Ultrassônico de nível: aparelho (esq.), trânsito pelo ar (dir.) Cortesia:

Endress+Hauser 56

Figura 3.20 - Estrutura típica de um sistema de suporte a decisão (Porto e Azevedo, 2002) ..... 59 xiv 
Figura 3.21 - Codificação otto - Cortesia ANA (2006). 65

Figura 3.22 - Bacias em que o SCBH foi implementado (Collischonn, 2014) ......................... 66

Figura 3.23 - Acesso ao SCBH via Web pelo endereço: http://scbh.ana.gov.br....................... 67

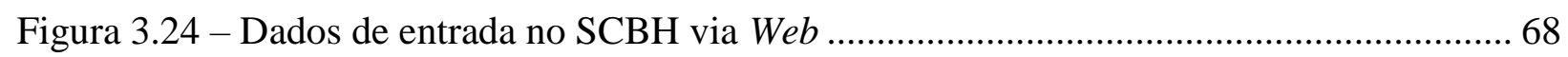

Figura 3.25 - Tela de identificação do manancial e município, detalhamento da demanda e regime a ser considerado, SCBH via Web. 68

Figura 3.26 - Tela com identificação do rio e município e detalhamento dos dados do lançamento de efluentes, SCBH via Web 69

Figura 3.27 - Tela com os resultados da análise em termos quantitativos, SCBH via Web ....... 70 Figura 3.28 - Tela com os resultados da análise em termos qualitativos, SCBH via Web ......... 70 Figura 4.1 - Sistematização do procedimento para classificação das vazões outorgadas ............ 75 Figura 5.1 - Fluxograma de entrada de uma vazão outorgada num trecho i, com classificação num dos três níveis de monitoramento pelos índices absolutos e relativos .93

Figura 5.2 - Bacia do São Francisco com as sub-bacias e os corpos de água 99

Figura 5.3- Representação dos trechos 1 a 3 (em azul escuro), localizados na sub-bacia do Alto São Francisco, Estado de Minas Gerais (Alto SF destacada em Verde Claro). 102 Figura 5.4 - Representação dos trechos 4 a 18 (em linhas cor azul claro e escuro), localizados na sub-bacia do Médio São Francisco (pintada em azul claro). 104 Figura 5.5 - Representação dos trechos 19 a 27 (em linhas cor azul escuro), localizados na subbacias do Médio (área em azul claro), Submédio (cinza) e Baixo São Francisco (amarelo) ..... 105 Figura 5.6 - Pontos de interferência outorgados pela ANA nos trechos 20 e 21, com destaque para os dados referentes à outorga de uso objeto da Resolução ANA 956/2013. 107 Figura 5.7 - Vazão máxima instantânea da declaração de uso constante no CNARH, como exemplificação de onde se extrai o $Q_{\text {captação }}$ 107 Figura 5.8 - Concentração máxima instantânea da DBO do efluente tratado, constante da declaração de uso no CNARH, como exemplificação de onde se extrai a DBO efluente ............... 108 Figura 5.9 - Fluxograma do SSD para classificação das outorgas de domínio da União da bacia do rio São Francisco 130

Figura C.1 - Localização das estações hidrométricas - Cortesia: Vector 157 Figura C.2 - Arquitetura geral do sistema com as 5 Estações de medição - Cortesia: Vector .. 157 Figura C.3 - Estação 1 Mazurek: tubulação de 300mm para pivô, com equip. instalados......... 158 Figura C.4 - Estação 2 - Areal: ponto de captação com tubulação de diâmetro de $75 \mathrm{~mm}$ e equipamentos instalados 159 
Figura C.5 - Estação 3-Geraldo Magela: tubulação de saída com diâm. 50mm e equip. instalados. 160

Figura C.6 - Estação 4 CAESB: tubulação de 700mm de diâmetro: acima, equipamento da CAESB já instalado; abaixo, dois equipamentos instalados pelo projeto piloto 161

Figura C.7 - Estação 5: Canal de Irrigação Santos Dumont: equipamentos instalados. 162

Figura C.8 - Mapa com as 5 Estações Hidrométricas (Fonte: http://ana.vector.com.br) 163

Figura C.9 - Tela principal da Estação Hidrométrica 1 - Mazurek 163

Figura C.10 - Gráfico e tabela dos dados de vazão instantânea - intervalo de 5 minutos - Estação Hidrométrica 1 - Mazurek, em 14/09/2014 (Fonte: http://ana.vector.com.br) 164

Figura C. 11 - Gráfico e tabela dos dados de volume totalizado - intervalo de 60 minutos - Estação Hidrométrica 1 - Mazurek, em 14/09/2014 (Fonte: http://ana.vector.com.br) 165

Figura C.12 - Figura demonstrativa da medição de vazão numa tubulação utilizando a pitometria (esq.) e tubo de Pitot tipo Cole (dir.). Cortesia: Vector 166

Figura C.13 - Figura demonstrativa do perfil de velocidades traçado com a pitometria (B), adotando-se uma velocidade média (C) para cálculo da vazão. Cortesia: Gustavo Carneiro .... 166 Figura C.14 - Gráfico dos dados de vazão instantânea - Estação Hidrométrica 1 - Mazurek, entre os dias 21 e 27/05/2014 (Fonte: http://ana.vector.com.br). 168 Figura C.15 - Gráfico dos dados de vazão instantânea - Estação Hidrométrica 1 - Mazurek, entre os dias 21 e 23/10/2015 (Fonte: http://ana.vector.com.br). 169

Figura C.16 - Estação 1 - Mazurek: Medição de vazão utilizando ultrassônico por tempo de trânsito, em 2 de julho de 2015 - vazão média: $157,1 \mathrm{~m}^{3} / \mathrm{h}$ 170

Figura C.17 - Estação 1 - Mazurek: Display do eletromagnético de carretel instalado na tubulação (acima, à esq.), retirado em ago/2014 para conserto (abaixo, à esq.) e reinstalado no painel (à direita)

Figura C.18 - Gráfico dos dados de vazão instantânea - Estação Hidrométrica 1 - Mazurek, entre os dias $1^{\circ}$ e 10/06/2014 (Fonte: http://ana.vector.com.br) ... 172

Figura C.19 - Estação 1 - Mazurek: Display do eletromagnético sem proteção (esq.) e com chapa de aluminío protegendo contra intempéries (dir.) 173

Figura C.20 - Gráfico dos dados de vazão instantânea - Estação Hidrométrica 2 - Areal, entre os dias 16 e 20/12/2013 (Fonte: http://ana.vector.com.br)

Figura C.21 - Estação 2 - Areal: equipamentos sem proteção (esq. - contorno em branco) e com proteção de chapa de alumínio (dir. - contorno em amarelo) 175

Figura C.22 - Estação 2 - Areal: retirada e limpeza do medidor de inserção 176 
Figura C.23 - Estação 2 - Areal: Gráfico da vazão instantânea x tempo, entre os dias 25/02 a 03/03/2015, com detalhe da chave de fluxo estar ligada de forma contínua (linha em preto). Fonte: http://ana.vector.com.br.

Figura C.24 - Gráfico dos dados de vazão instantânea - Estação Hidrométrica 3 - Magela, entre os dias 13 e 18/10/2015 (Fonte: http://ana.vector.com.br). 178

Figura C.25 - Estação 3 - Magela: detalhe da válvula de pressão instalada no final, para diminuição da vazão, para envio de água às estufas mais próximas. 179

Figura C.26 - Estação 3 - Magela: limpeza de filtro de disco (esq.). 180

Figura C.27 - Gráfico dos dados de vazão instantânea - Estação Hidrométrica 4 - CAESB, entre os dias $1^{\circ}$ e 5/11/2013 (Fonte: http://ana.vector.com.br)

Figura C.28 - Gráfico dos dados de vazão instantânea do ultrassônico por tempo de trânsito Estação 4 - CAESB, entre os dias 28/09 e 02/10/2015 (Fonte: http://ana.vector.com.br) ..... 182 Figura C.29 - Planilha com leituras de vazão instantânea do medidor eletromagnético carretel instalado na ETA Pipiripau - mês outubro de 2015 (Fonte: CAESB). 183 Figura C.30 - Gráfico dos dados de volume totalizado - Estação Hidrométrica 4 - CAESB, entre os dias $1^{\text {o }}$ e 30/11/2013 (Fonte: http://ana.vector.com.br) 183 Figura C.31 - Gráfico dos dados de vazão instantânea - Estação Hidrométrica 5 - Santos Dumont, entre os dias $1^{\mathrm{o}}$ e 17/12/2013 (Fonte: http://ana.vector.com.br) 185 Figura C.32 - Medição de vazão no canal Santos Dumont utilizando medidor ultrassônico doppler denominado Flowtracker, em 21/02/2014 (relatório de medição à direita) 186 Figura C.33 - Calha Parshall com maior nível d'água nos dois anos de operação, em 19 de fevereiro de 2015, sem afogamento 187

Figura C.34 - Localização de instalação dos equipamentos no canal Santos Dumont.............. 188 Figura C.35 - Vazamentos em juntas de dilatação entre a calha Parshall e o vertedouro ......... 189 Figura C.36 - Vertedouro em regime de operação normal (esq.), em 23/10/2015, e vertedouro afogado na $2^{\mathrm{a}}$ quinzena de fevereiro de 2015 (dir.), foto tirada em 19/02/2015 ....................... 189 Figura C.37 - Vertedouro sem a crista de alumínio (esq.), e com a crista reinstalada (dir.) ..... 189 Figura C.38 - Gráfico comparativo de medições do vertedouro com a calha Parshall, em julho de 2015. Círculo azul: retirada da chapa; círculo laranja: reinstalação da chapa. (Fonte: http://ana.vector.com.br) 190 


\section{LISTA DE TABELAS}

Tabela 3.1- Casos hipotéticos de disponibilidade hídrica em trechos de rio

Tabela 3.2- Critérios de outorga de direito de uso da água em alguns Estados brasileiros

(Benetti et al., 2003) 28

Tabela 3.3- Média de preços de hidrômetros Woltmann 36

Tabela 3.4- Média de preços de eletromagnéticos de carretel a bateria 37

Tabela 5.1 - Exigência para os usuários outorgados, para cada um dos três estágios de classificação quanto ao uso de recursos hídricos.... .85

Tabela 5.2 - Definição dos índices relativos para classificação dos três estágios .............. 92

Tabela 5.3- trechos da sub-bacia do Alto São Francisco (Estado de Minas Gerais) ......... 101

Tabela 5.4 - trechos da sub-bacia do Médio São Francisco................................................ 102

Tabela 5.5- trechos da sub-bacia do Médio, Submédio e Baixo São Francisco 105

Tabela 5.6 - Classificação dos pontos de interferência do trecho 1 - nascente do Rio São Francisco, da confluência com o rio Samburá até o Reservatório de 3 Marias

Tabela 5.7 - Classificação dos pontos de interferência localizados nos 9 trechos de menor porte - Cenário 1

Tabela 5.8 - Classificação dos pontos de interferência localizados nos 18 trechos de maior porte - Cenário 1

Tabela 5.9 - Classificação dos pontos de interferência localizados nos 9 trechos de menor porte - Cenário 2

Tabela 5.10 - Classificação dos pontos de interferência localizados nos 18 trechos de maior porte - Cenário 2

Tabela 5.11 - Classificação dos pontos de interferência localizados nos 9 trechos de menor porte - Cenário 3

Tabela 5.12 - Classificação dos pontos de interferência localizados nos 18 trechos de maior porte - Cenário 3

Tabela 5.13 - Classificação dos pontos de interferência localizados nos 9 trechos de menor porte - Cenário 4

Tabela 5.14 - Classificação dos pontos de interferência localizados nos 18 trechos de maior porte - Cenário 4

Tabela 5.15 - Distribuição do número de pontos de interferência nos três estágios de exigência quanto ao monitoramento - Cenário 4 123 
Tabela 5.16 - Distribuição das vazões outorgadas nos três estágios de exigência quanto ao

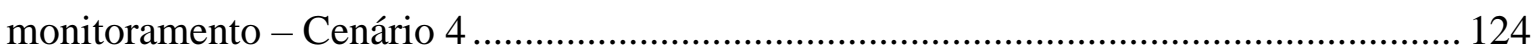

Tabela C.1 - Comparação entre medições de vazão no canal Santos Dumont .................. 186

Tabela D.1 - Tabela resumo dos equipamentos de medição de vazão para condutos forçados (tubulação sob pressão) 191

Tabela D.2 - Tabela resumo dos equipamentos de medição de vazão para superfície livre (canais abertos) 195

Tabela D.3 - Tabela resumo dos dispositivos acumuladores de tempo. 197 


\section{INTRODUÇÃO}

A palavra hidráulica significa "condução de água", formada do grego hydor (água) e aulos (tubo, condução). De uma maneira geral, a hidráulica compreende o estudo do comportamento da água e de outros líquidos, quer em repouso, quer em movimento (Azevedo Netto et al., 2002).

As aplicações da Hidráulica estão ligadas a diversas áreas onde há utilização dos recursos hídricos. Na área urbana, destacam-se os sistemas de abastecimento de água, esgoto e drenagem pluvial, bem como as instalações prediais. Na área rural, a hidráulica está presente nos sistemas de irrigação e drenagem. A hidráulica também se faz presente nas atividades de navegação, geração de energia e defesa contra inundações.

Outra área de estudos fortemente relacionada aos recursos hídricos é a Hidrologia. De uma maneira geral, a Hidrologia pode ser entendida como o estudo da água sobre a terra, sua ocorrência, distribuição e circulação, bem como suas propriedades e efeitos sobre o meio ambiente e a vida. Em uma definição mais restrita, a hidrologia passou a ser o estudo da parte terrestre do ciclo hidrológico, mais especificamente da precipitação e do escoamento (Santos et al., 2003).

Também há, na Hidrologia, diversas aplicações ligadas às áreas de projetos de recursos hídricos, desde as fases de planejamento e construção, até a operação e manutenção de reservatórios, usinas hidrelétricas, projetos de aquicultura, irrigação, navegação, indústria e abastecimento humano. Objetiva-se, com a Hidrologia, a observação, a medição, o processamento e a previsão de dados relacionados à ocorrência e à circulação da água.

Há uma atividade em comum que perpassa pela Hidráulica e pela Hidrologia: a Hidrometria. Na Hidráulica, Azevedo Netto et al. (2002) afirmam que a Hidrometria é a área responsável pela medida de variáveis como profundidade, variação no nível da água, seções de escoamento, pressões, velocidades e vazões ou descargas. Já Santos et al. (2003) destacam que a Hidrometria é a responsável pela medição das variáveis hidrológicas (precipitação, evapotranspiração, vazão e armazenamento). 
A primeira ideia que vem à mente, quando se fala em medir a variação de nível ou a vazão, é a medição em um rio. $\mathrm{Na}$ área da Hidrologia, os dados das medições de chuvas (pluviometria), níveis e vazões em campo, possibilitam a aplicação dos modelos matemáticos que permitem estimar as futuras chuvas e/ou vazões, aos eventos raros (estiagens e cheias) e quantificar as possibilidades do aproveitamento dos recursos hídricos.

Sendo assim, a hidrometria tem papel fundamental para o conhecimento e a previsão do regime de vazões de um determinado corpo d'água, a fim de que se possa planejar a quantidade de água disponível a ser ofertada. Isso porque a água doce tem-se tornado um recurso escasso para atender certas regiões, devido ao aumento populacional, à deterioração da qualidade e à diminuição da quantidade da água pelos impactos das atividades humanas sobre os recursos ambientais. Por isso, a gestão do uso da água e sua conservação são uns dos principais desafios do desenvolvimento sustentável (Carolo, 2007).

Sabendo que no Brasil a água é um bem público e que cabe ao Estado definir o ordenamento de sua utilização, a hidrometria é uma ferramenta importante para a base de dados de cada órgão gestor de recursos hídricos definir a quantidade de água que pode ser ofertada em determinado corpo d'água. Tendo a análise de disponibilidade hídrica em mãos, seu uso é permitido mediante a emissão da outorga de direito do uso da água, havendo, contudo, usos considerados insignificantes (definidos em leis, portarias e resoluções), que independem de outorga.

Carolo (2007) define a outorga como um instrumento de comando e controle, por meio do qual o Poder Público autoriza o uso da água em condições e prazos pré-estabelecidos. A outorga pode ser utilizada na mitigação ou na solução de conflitos pelo acesso à água, tendo em vista o uso múltiplo desse recurso natural.

Ora, diversos podem ser os usuários outorgados responsáveis pela demanda por água disponível, com diferentes finalidades de uso, como abastecimento humano e industrial, lançamento e dispersão de efluentes domésticos e industriais, geração de energia elétrica, irrigação, pecuária, aquicultura, mineração, dentre outros. Aliado a esses usos, deve ser ainda considerada a parcela de água referente à demanda ecológica. Se há monitoramento e controle do Poder Público da quantidade de água em determinado corpo d'água ofertada e disponível para uso, quem controla o outro lado, ou seja, a água retirada do rio pelos usuários? 
Para resposta a esse questionamento, surge uma parte da hidrometria, ligada à área da hidráulica, responsável pela medição de vazões em tubos (condutos forçados) e calhas ou canais (superfície livre) para averiguação das reais vazões utilizadas pelos usuários outorgados.

Os equipamentos de medição de vazão de tubos e canais existentes no mercado são normalmente utilizados pelos usuários para um controle interno da quantidade de água de sua produção. Como exemplo, verifica-se a importância de conhecer a quantidade de água para a produção de um determinado bem, quando a mesma é um insumo numa área industrial. Outro caso é o de saber a quantidade de água retirada para tratamento e utilização de químicos, na área de abastecimento público. Também, na irrigação, é importante a medição de água para auxiliar a maximização da produtividade de certa plantação.

Cabe aqui comentar a possibilidade de se estimar o consumo de água de forma indireta, relacionando a produção do bem com a necessidade de água. Esse é justamente o cálculo que o Poder Público utiliza para determinação da vazão outorgada. Como exemplo, na indústria de açúcar e álcool, o consumo médio é de $10 \mathrm{~m}^{3}$ de água para cada tonelada de cana esmagada. Entretanto, esse consumo pode variar de 2 a $20 \mathrm{~m}^{3}$ de água/ton. de cana, dependendo do tipo de usina, do percentual de produção de açúcar e álcool, da tecnologia de produção e do reuso da água (Almeida, 2009). Em outras palavras, no exemplo da indústria sucroalcooleira, a variação do consumo de água chega a ser de 10 vezes entre as usinas de menor consumo, para as de maior consumo.

A medição de forma indireta representa um indicativo de consumo, podendo ter uma grande variabilidade em termos de conhecer o quantitativo de água necessário para a produção de um determinado bem. Sendo assim, não pertence ao escopo do presente projeto, que está focado no real consumo da água, encontrado por meio da medição na forma direta, utilizando equipamentos de medição de vazão de água bruta.

No entanto, antes de se pensar na instalação de equipamentos para saber o quantitativo de água e, assim, chegar à demanda pelo uso da mesma, surge um questionamento anterior: é realmente necessário medir? Alternativamente, um simples controle ou monitoramento por parte dos usuários não é suficiente para o gerenciamento dos recursos hídricos? 
Pelo desenvolvimento deste trabalho, verifica-se que o controle das vazões por parte dos usuários outorgados depende de uma série de condições, como a localização e a condição individual ou coletiva dos usos, que levam à necessidade ou não da medição de vazões e, sendo necessário medir, quais tipos de equipamentos seriam recomendados.

Para controle e monitoramento de vazões outorgadas, desenvolveu-se uma metodologia para classificar as vazões em níveis gradativos de exigência quanto ao monitoramento, indo desde a simples declaração da capacidade instalada para captação ou lançamento, até a necessidade de instalar equipamento de medição e de informação do volume de água demandado ao órgão gestor outorgante.

Para verificar a aplicabilidade desta metodologia, foi utilizado como estudo de caso a bacia do rio São Francisco, tendo sido dívida em 27 trechos de rio e reservatórios de domínio da União, com condições de demanda e disponibilidade hídrica diversas

O presente trabalho apresenta a seguinte estrutura:

No Capítulo 2, são apresentados os objetivos geral e específicos.

O referencial teórico está contido no Capítulo 3. Esse capítulo é dividido em quatro partes, a primeira delas trata das bases conceituais do uso de recursos hídricos e monitoramento, com ênfase na parte legal do assunto. A segunda relata a necessidade da medição de vazão e as variáveis que influenciam na demanda pelo uso de recursos hídricos. Em sequência, na terceira parte são descritos os principais equipamentos de medição de vazão existentes no mercado, demonstrando o princípio de funcionamento, a aplicabilidade, a necessidade de manutenção e a precisão de medida de cada um. Na última parte são apresentados os conceitos relacionados ao sistema de apoio à decisão, com ênfase àqueles que tratam de outorga de direito do uso de recursos hídricos.

O Capítulo 4 traz a metodologia do trabalho, com as atividades a serem desenvolvidas.

No Capítulo 5, apresentam-se os resultados, tendo sido dividido em quatro partes. Inicialmente, definem-se quais equipamentos de medição de vazão são mais adequados para instalação, dependendo do tipo de uso, sendo tubulação fechada (condutos forçados) ou superfície 
livre (canais abertos). Em seguida, é elaborada uma sistematização de procedimentos para que se possa estabelecer um nível de importância para as vazões outorgadas, classificandoas em diferentes níveis de monitoramento em uma determinada bacia. Depois, realiza-se uma verificação dos procedimentos com dados reais de vazões outorgadas na bacia do rio São Francisco, como estudo de caso. Finalmente, elabora-se um fluxograma com os resultados do estudo de caso, de forma a possibilitar a construção de um sistema de suporte à decisão para controle de vazões outorgadas.

O Capítulo 6 contém as conclusões e as recomendações desta dissertação.

Como complementação no que se refere aos equipamentos de medição de vazão, apresentase em Apêndice uma etapa experimental do trabalho, que consiste na aquisição, instalação e funcionamento de diversos equipamentos de medição constantes de um projeto-piloto na bacia do ribeirão Pipiripau, com vistas a recomendação de equipamentos adequados para medição de vazão em canais livres e condutos forçados. 


\section{OBJETIVO}

\section{OBJETIVO GERAL:}

- Desenvolver procedimentos de classificação de vazões outorgadas, em níveis diferenciados, de forma a estabelecer alternativas de monitoramento.

\section{OBJETIVOS ESPECÍFICOS:}

- Elaborar uma metodologia para o monitoramento e medição das vazões outorgadas aos usuários de recursos hídricos de uma bacia, pela criação de indicadores que definem a significância dessas vazões.

- Testar a metodologia desenvolvida nos corpos hídricos de domínio da União da bacia do rio São Francisco, verificando as condições de monitoramento estipuladas aos usuários outorgados na referida bacia.

- Avaliar processos de medição de vazão para recomendação de equipamentos a serem instalados em tubulações fechadas e canais abertos. 


\section{REVISÃO TEÓRICA E BIBLIOGRÁFICA}

\subsection{O USO DE RECURSOS HÍDRICOS E SEU MONITORAMENTO}

Em nosso país, a Política Nacional de Recursos Hídricos - PNRH, preconizada pela lei ${ }^{\circ}$ 9.433, de 8 de janeiro de 1997, baseia-se em fundamentos de que a água é um bem de domínio público, sendo um recurso natural limitado e dotado de valor econômico (Brasil, 1997). O domínio público da água advém da Constituição da República Federativa do Brasil - CF, de 1988, preconizando nos Arts. 20, III e 26, I que as águas superficiais de lagos e rios e as subterrâneas constituem bens da União e dos Estados (Brasil, 1998).

No que diz respeito a ser um recurso limitado, os diversos usos da água - abastecimento humano, dessedentação animal, irrigação, indústria, geração de energia elétrica, aquicultura, navegação, lazer, etc. - podem ser concorrentes numa determinada região ou bacia. Há, portanto, uma necessidade de geri-los de modo a atender às demandas presentes e futuras de água (Silva e Monteiro, 2004).

O Poder Público, estadual ou federal, tem a responsabilidade por regular o uso dos recursos hídricos, ou seja, autorizar e verificar o uso de qualquer intervenção num corpo de água. Essa autorização, denominada de outorga de direito de uso de recursos hídricos, é um dos instrumentos criados pela PNRH. A outorga é um ato administrativo do Poder Público outorgante (União, Estados ou Distrito Federal), que faculta ao outorgado (usuário da água) o uso de recurso hídrico, em condições expressas no respectivo ato e por prazo determinado.

Cabe aqui um parêntesis para definir o domínio das águas: segundo a CF1988, as águas de domínio da União são aquelas que banham mais de um estado da Federação, fazem fronteira entre estados nacionais e com outros países. Também estão nessa condição as águas acumuladas em represas construídas com aporte de recursos da União e o Mar Territorial brasileiro, incluindo baías, enseadas e estuários, além das águas que cruzam território de domínio da União (Brasil, 1988). Dessa forma, são exemplos de mananciais cujas águas são de domínio da União: rio Paraná (Brasil, Paraguai e Argentina) e rio Paraíba do Sul (São Paulo, Minas Gerais e Rio de Janeiro). Por outro lado, são de domínio dos estados e do Distrito Federal as 
águas de rios e lagos que se encontram apenas em seus limites, bem como as águas subterrâneas. São exemplos: Rio Tietê (São Paulo), Lagoa dos Patos (Rio Grande do Sul) e Rio das Velhas (Minas Gerais).

Em relação ao poder outorgante, de acordo com a Lei 9984, de 19 de dezembro de 2000, a Agência Nacional de Águas - ANA tem a competência de outorgar o direito do uso dos recursos hídricos dos corpos de água de domínio da União (Brasil, 2000a). Em contrapartida, cada estado da Federação possui um órgão gestor responsável pela outorga de direito dos recursos hídricos pertencentes a seu estado.

\subsubsection{O monitoramento dos recursos hídricos no âmbito legal brasileiro}

Segundo o Art. 11 da Lei 9.433/97, um dos objetivos em relação ao regime de outorga é a necessidade de que seja assegurado um controle quantitativo e qualitativo dos usos da água (Brasil, 1997). Entende-se que tal controle quantitativo das vazões captadas e lançadas significa mais que permitir o uso de determinada quantidade de água (seja para captação da água bruta, seja para diluição de efluentes lançados) por meio do ato da outorga: envolve também o efetivo controle do cumprimento dessas outorgas.

E tal controle deve ser feito, tanto que a Lei 9.433, estabelece, em seu art. 49, como infrações de normas de utilização de recursos hídricos: "utilizar-se dos recursos hídricos ou executar obras ou serviços relacionados com os mesmos em desacordo com as condições estabelecidas na outorga" no inciso IV, além de "fraudar as medições dos volumes de água utilizados ou declarar valores diferentes dos medidos" no inciso VI (Brasil, 1997). Embora a referida Lei não cite, explicitamente, a medição dos volumes utilizados, ao considerar infração a sua fraude ou falsa informação, pressupõe, assim, que tais medições devam ou possam ser realizadas.

O primeiro comando legal relacionado ao monitoramento de vazão de uso de recursos hídricos adveio com a publicação pelo Ministério do Meio Ambiente, então responsável pela outorga de uso de recursos hídricos de domínio da União, da Instrução Normativa $n^{\circ} 4$, de 21 de junho de 2000 (Brasil, 2000b), que estabeleceu:

Art. 44. O outorgado deverá implantar e manter em funcionamento equipamentos de medição para monitoramento contínuo da vazão captada e lançada. 
Posteriormente, a Resolução no 16 do Conselho Nacional de Recursos Hídricos - CNRH, de 8 de maio de 2001, delibera sobre os critérios de outorga de direito de uso de recursos hídricos (Brasil, 2001), determinando:

Art. 31. "O outorgado deverá implantar e manter o monitoramento da vazão captada elou lançada e da qualidade do efluente, encaminhando à autoridade outorgante os dados observados ou medidos na forma preconizada no ato da outorga".

\subsubsection{Exigências da ANA quanto ao monitoramento e medição}

No âmbito da ANA, a partir da Resolução de Outorga ANA n ${ }^{\circ} 123$, de $1^{\circ}$ de setembro de 2002, as outorgas de direito de uso de recursos hídricos constam da seguinte exigência: " $O$ Outorgado deverá implantar e manter em funcionamento equipamentos de medição para monitoramento contínuo da vazão captada" (Brasil, 2002). Sendo assim, a ANA adota uma exigência mais restritiva que a Resolução $\mathrm{n}^{\circ} 16$ do CNRH, uma vez que estabelece a implantação de equipamento de medição ao usuário, não somente monitoramento da vazão.

Complementarmente, em relação ao encaminhamento de dados medidos, também preconizados na Resolução no 16 do CNRH, a Agência publica a Resolução nº 425/2004, onde estabelece a obrigatoriedade da instalação de sistema de medição (mais complexo e dispendioso) e do encaminhamento de uma Declaração Anual de Uso de Recursos Hídricos DAURH à ANA, contendo uma totalização mensal dos volumes medidos. De acordo com o inciso III do art. $2^{\circ}$ da referida Resolução, considera-se "sistema de medição" o conjunto de instalações, equipamentos, acessórios, instrumentos e dispositivos que registra e permite o monitoramento dos volumes retirados e lançados em um corpo hídrico (Brasil, 2004a).

A Resolução $n^{\circ}$ 425/2004, foi revisada e atualizada pela Resolução ${ }^{\circ} 782 / 2009$, em que a exigência do envio de informações fica restrita a usuários localizados em bacias críticas (constantes do Anexo I dessa Resolução) e com vazão de captação e/ou lançamento superiores a certo valor de vazão, dependendo da finalidade do uso. Exemplificando, em empreendimentos com as finalidades de indústria e de saneamento, o usuário cuja outorga prevê um valor de vazão captada superior a 20 1/s, ou lançada superior a 15 1/s, deve enviar à ANA os volumes mensais utilizados (Brasil, 2009). 
Em 2015, a Agência publicou a Resolução ANA n 603, de 26 de maio, atualizando a Resolução 782/2009 e estabelecendo um conceito mais abrangente de monitoramento dos usos outorgados que devem preencher a Declaração Anual de Uso de Recursos Hídricos DAURH e enviar à ANA (Brasil, 2015a). No Art. $4^{\circ}$ da Resolução, a ANA define como monitoramento:

I. O registro dos volumes de captação e/ou lançamento obtidos através de medição de pelo menos um dos seguintes parâmetros: velocidade do fluxo, vazão, volume ou nível d'água;

II. O registro dos volumes de captação e/ou lançamento obtidos através de medições indiretas ou estimativas, desde que haja aferição do tempo de funcionamento do sistema, ou consumo de energia;

III. O registro de dados obtidos por meio da análise de um ou mais dos seguintes parâmetros de qualidade do efluente: Demanda Bioquímica de Oxigênio - DBO, temperatura, nitrogênio e/ou fósforo.

A Agência ainda estabelece que os equipamentos a serem instalados pelos usuários outorgados, bem como as estimativas realizadas por estes, devem apresentar dados coerentes. Além disso, que deverá ser considerado o tipo e o porte do empreendimento para adequação dos sistemas de monitoramento, e que estes estarão sujeitos à avaliação da Agência.

Ainda em 2015, foi publicada a Resolução 632, definindo limites a serem observados temporariamente em algumas bacias de domínio da União, para obrigatoriedade de monitoramento e envio da Declaração Anual de Uso de Recursos Hídricos - DAURH (Brasil, 2015b). Em seguida, foram publicadas as Resoluções de $\mathrm{n}^{\circ}$ 126, 127, 128, 129, 130 e 131/2016, para as bacias dos rios Doce, Preto, Bezerra, Quarai, São Francisco, São Marcos e Verde Grande, respectivamente, estabelecendo vazões mínimas as quais devem ser monitorados os volumes outorgados e enviada a DAURH (Brasil, 2016).

Consequentemente, há uma preocupação da Agência em conhecer o volume de água utilizado pelos usuários outorgados, diferenciando os usos por bacia depende da bacia e porte do usuário. Mais que isso, percebe-se que há uma evolução no que diz respeito ao refinamento da atividade de fiscalização do uso de recursos hídricos, no que tange à definição de vazões específicas por bacia, a partir das quais os usuários outorgados são obrigados ao envio de informações. 
Entretanto, cabe aqui tecer uma crítica a respeito das obrigações impostas pela ANA: não há clareza nem critérios para definição do tipo de exigência quanto ao monitoramento que o usuário outorgado deve adotar. Num primeiro momento, a partir de 2003, a Agência estabelece que todos usuários por ela outorgados instalem equipamentos de medição de vazão. Depois, a partir da Resolução de 603/2015, diminui as restrições de exigência, e estabelece que os usuários mais significativos, diferenciados por consumo e por bacia, devem realizar monitoramento, que pode ser instalação de equipamento, ou até mesmo verificação indireta por consumo de energia.

Complementando, a Agência informa que o tipo de monitoramento a ser instalado deve ser avaliado, mas não detalha como, nem quem deve instalar. Pelo constatado, exige-se demais num primeiro momento, em 2003, e diminui-se o nível de exigência noutro momento posterior, em 2015, mas não se deixa claro como as outorgas devem atender às demandas relativas ao monitoramento.

\subsubsection{Exigências dos órgãos gestores de recursos hídricos estaduais}

Os órgãos gestores estaduais de recursos hídricos, em suas respectivas leis, decretos, portarias e resoluções, estabelecem distintas exigências quanto ao monitoramento da vazão utilizada pelos usuários outorgados, conforme se pode observar no Apêndice A desta dissertação. As exigências legais dos órgãos estaduais são resumidas a seguir:

- Não foi constatada exigência legal: AC, AP, ES, MA, MS, PB e PE (7 Estados);

- Monitorar a vazão ou instalar equipamento de medição: AL, CE, DF, MG, PA, RJ, RN, RR, RS, SC, SP (10 Estados + DF);

- Instalar equipamentos de medição e enviar dados ao órgão outorgante: AM, BA, GO, MT, PI, PR, RO, SE, TO (9 Estados). 


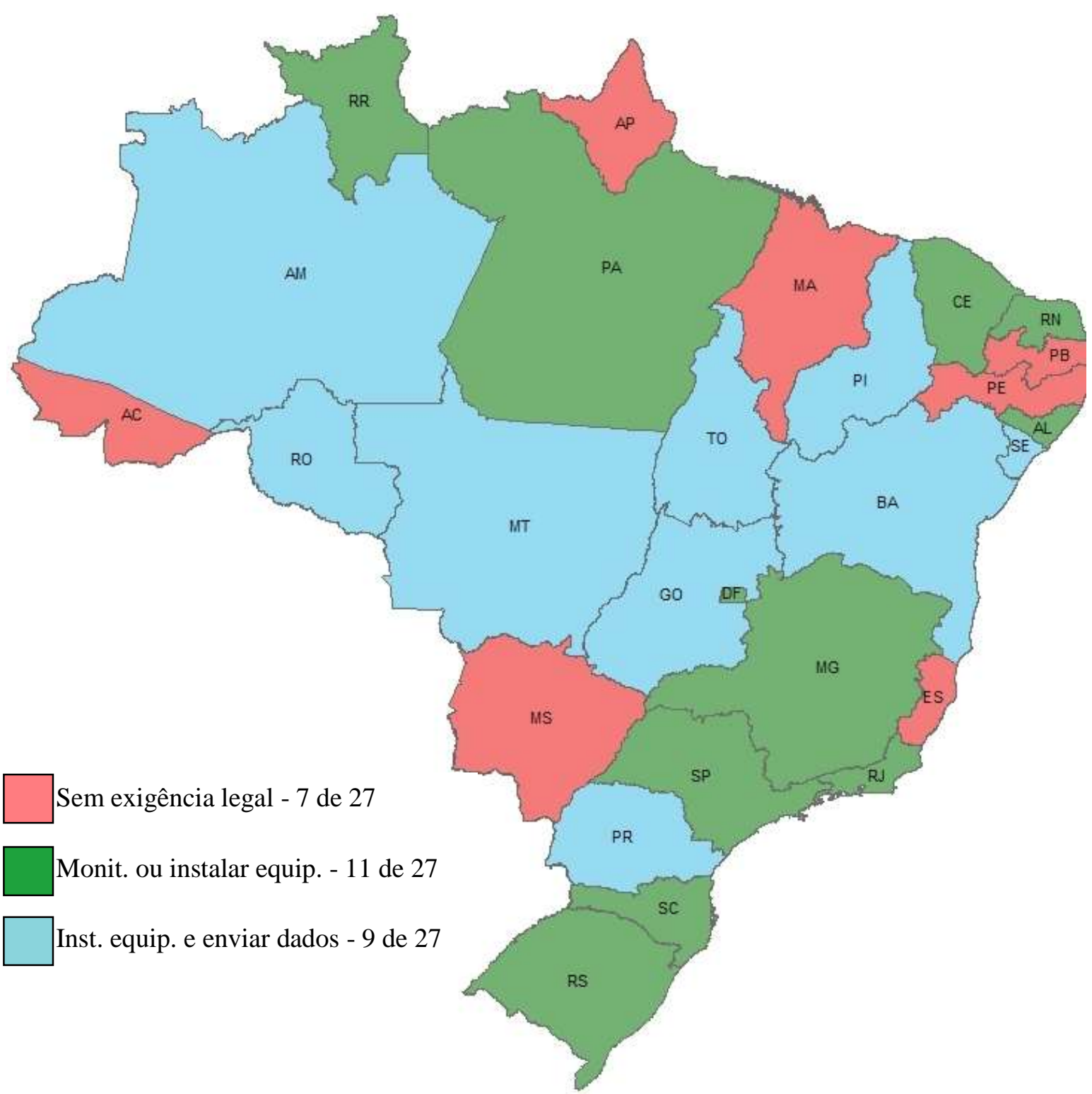

Figura 3.1 - Mapa de classificação das Unidades Federativas do Brasil quanto às exigências legais para monitoramento dos usos outorgados

Conforme pode ser observado pela figura acima, a maioria dos Estados, com destaque em verde e azul, possui exigência legal de, no mínimo, instalação de equipamentos hidrométricos ou monitoramento da vazão. Apesar de existirem essas obrigações em lei, alguns Estados, na prática, sequer implantaram efetivamente o instrumento da outorga de direito de uso de recursos hídricos. Exemplificando: segundo levantamento feito por Couceiro e Hamada (2011), nem todos os Estados da região Norte do Brasil realizam, de fato, a outorga de direito de uso. Além do mais, aqueles que implementaram esse instrumento, o realizam como um processo puramente burocrático, cartorial, sem que haja fiscalização e controle do uso. 
Em contrapartida, outros Estados já estão bastante avançados na questão do controle dos usos outorgados. O Ceará, pela falta de disponibilidade hídrica em seus mananciais, é o mais avançado deles, uma vez que essa unidade federativa já realiza a cobrança da água bruta, além da outorga. De acordo com o Decreto Estadual 30.629, de 19 de agosto de 2011, os usuários outorgados devem instalar hidrômetro volumétrico, aferido e lacrado por fiscais da Companhia de Gestão de Recursos Hídricos do Estado do Ceará - COGERH (órgão gestor estadual de recursos hídricos), ou realizar medições frequentes de vazões, onde seja inapropriada a instalação de hidrômetros convencionais. Podem também fazer estimativas indiretas de consumo, considerando uma série de fatores, como as dimensões das instalações dos usuários, os diâmetros das tubulações, a carga manométrica da adução, etc. (Ceará, 2011).

No DF, a Agência Reguladora de Águas e Saneamento do Distrito Federal - ADASA determina, na Resolução n 350/2006, que o outorgado realize medições diárias de vazão e faça envio das informações mensalmente à ADASA. Além disso, obriga que a medição em poços deva ser feita por hidrômetro e, nos demais usos, pode ser utilizado sistema de medição de vazão compatível ou dispositivo para medição do nível de água (Distrito Federal, 2006).

O Instituto Mineiro de Gestão das Águas - IGAM, pela Portaria nº 49/2010, determina aos usuários outorgados pelo Estado de Minas Gerais a instalação de equipamento de medição de vazão, tais como vertedouros, hidrômetros e outros, ou a instalação de equipamentos medidores de tempo de uso, tais como horímetros, dependendo da exigência estabelecida na outorga (Minas Gerais, 2010).

Já a Bahia segue a mesma linha adotada da ANA: exige que certos usuários, acima de um limite estabelecido na Instrução Normativa Ingá n ${ }^{\circ}$ 08-A/2009, devem instalar, operar e manter seu sistema de medição, e transmitir ao Instituto do Meio Ambiente e Recursos Hídricos (INEMA) a relação dos volumes medidos a cada mês (Bahia, 2010).

Em suma, de todas as unidades federativas brasileiras, três delas (CE, MG e DF) apresentam em sua legislação uma definição dos equipamentos de medição de vazão a serem utilizados. Entretanto, são bastantes vagas no sentido de permitirem qualquer sistema de medição, seja direto, por utilização de hidrômetros, seja indireto, por uso de horímetros ou estimativas de vazão. 
De qualquer forma, cristaliza-se assim o conceito que o usuário de recursos hídricos outorgado pela ANA e pela maioria dos órgãos gestores estaduais deve (no sentido de ter a obrigação de) monitorar a vazão que utiliza por meio de equipamentos de medição. Em alguns Estados e na ANA, além da necessidade de medição, há obrigação do envio dos dados medidos ao órgão gestor de recursos hídricos para controle e monitoramento.

\subsubsection{Dificuldades para normatização do monitoramento}

Conforme visto anteriormente, nas outorgas de direito de uso emitidas pela maioria dos órgãos gestores de recursos hídricos estaduais brasileiros e pela ANA, há uma obrigatoriedade imposta aos usuários para medição das vazões efetivamente captadas ou lançadas. Em alguns casos, há a necessidade de encaminhar os dados de medição, dependendo do ato estabelecido na outorga, do porte do usuário ou da bacia onde se localiza, de acordo com o estabelecido em cada legislação. Entretanto, apesar dessas exigências, somente CE, MG e DF regulamentam, de forma geral e sem aprofundamento da questão, quais tipos de medidores devem ser instalados pelos usuários.

Tal fato se deve à complexidade do tema, uma vez que, para que a fiscalização desses órgãos gestores possa de fato exercer o papel de controle dos usos outorgados, é essencial que os valores dos volumes declarados pelos usuários outorgados tenham confiabilidade. Em outras palavras, é necessária uma definição da adequabilidade na instalação, operação e manutenção dos equipamentos e sistemas de medição de vazão de água bruta instalados pelos usuários.

Exemplificando essa dificuldade de definição de equipamentos e de sistemas de medição, as seguintes variáveis podem influenciar nos resultados dos volumes de água apropriados pelos usuários, dependendo da escolha dos tipos a serem instalados:

- Em relação à forma de adução da água: pela Mecânica dos Fluidos, conforme Streeter (1977), a água pode ser aduzida por tubulação fechada (condutos sobre pressão) ou por superfície livre (canais e calhas). Para cada um desses tipos, existem equipamentos específicos para medição de água;

- Em relação à forma de medição: há equipamentos que medem a velocidade (v), e multiplicando pela área da seção $(\mathrm{A})$ fornecem a vazão do sistema $(\mathrm{Q}=\mathrm{v} \times \mathrm{A})$. Esses equipamentos podem possuir (ou não) registradores para acumulação dos dados ao 
longo do tempo (t), realizando assim apropriação do volume (V) de água utilizado $(\mathrm{V}=\mathrm{Q} \times \mathrm{t})$. Há também equipamentos que relacionam altura de lâmina d'água $(\mathrm{H})$ à vazão por fórmulas do tipo $\mathrm{Q}=\mathrm{a} \times \mathrm{H}^{\mathrm{b}}$, sendo "a" e "b" constantes. Há também registradores de tempo, que medem tão somente o período de funcionamento da captação de água;

- Em relação ao tipo de água (bruta ou tratada): Os hidrômetros, equipamentos de medição mais conhecidos, são fabricados para medir a água tratada que chega às residências. Há equipamentos apropriados para medição de água tratada, mas para medição de água bruta não são recomendados, pois as impurezas da água podem comprometer a medição ao longo do tempo (Ex: hidrômetros e pressão diferencial com tubo Pitot). Existem também equipamentos adequados para medição somente da água bruta, pois, na verdade, medem a velocidade das partículas sólidas presentes no fluxo. Finalmente, há equipamentos que podem ser utilizados para medição tanto da água bruta como da tratada;

- Em relação ao preço dos equipamentos: dependendo da precisão, tecnologia envolvida e diâmetro da tubulação, a variação de preços para aquisição dos equipamentos é considerável. De acordo com pesquisas de mercado, os preços dos medidores variam desde $\mathrm{R} \$ 30$ (horímetro mecânico) até $\mathrm{R} \$ 25.000$ (ultrassônico por tempo de trânsito);

- Em relação à precisão de medida: a precisão significa o grau de refinamento com que uma operação é executada ou uma medida é indicada. Segundo Pinto (2003), existe variação na precisão de medida dos equipamentos entre $0,5 \%$ a $15 \%$, dependendo da tecnologia adotada e forma de instalação;

- Em relação à forma de instalação: os equipamentos de medição podem apresentar valores discrepantes da realidade, se não forem instalados de forma adequada. Por isso, devem ser instalados segundo as instruções dos fabricantes.

Tendo em vista as variáveis apresentadas, para que haja eficiência no controle do uso de recursos hídricos outorgados pelo Poder Público, é premente a necessidade de se definirem, e de se mais bem conhecerem, os vários tipos de equipamentos de medição de vazão de água 
bruta disponíveis no mercado, suas tecnologias, métodos de instalação e adequabilidade em relação à operação, à manutenção e ao registro dos dados de vazão e volume de água.

Complementarmente, nas diversas ações fiscalizatórias dos órgãos gestores de recursos hídricos, para averiguação dos cumprimentos das condições estabelecidas nas respectivas outorgas de direito de uso, verifica-se, em campo, que a grande maioria dos usuários não dispõe de equipamento de medição de vazão instalado. Não havendo legislação específica sobre o tema, a maior parte dos órgãos gestores, em suas atividades de fiscalização, flexibiliza a obrigatoriedade de instalação de equipamentos. E quando exige, como é o caso da fiscalização na ANA, depende da interpretação pessoal de um fiscal, e não de uma norma definida pela instituição.

Por outro lado, segundo informações obtidas junto à ANA e aos órgãos gestores dos Estados da $\mathrm{BA}, \mathrm{CE}, \mathrm{MG}$ e do $\mathrm{DF}$, vários usuários outorgados entram em contato com as respectivas entidades outorgantes questionando qual equipamento devem instalar para cumprir as exigências estabelecidas na outorga, para atenderam aos padrões internacionais exigidos pelas normas ISO (International Organization for Standardization), por exemplo. À exceção do Ceará, que já tem um medidor volumétrico pré-estabelecido pela COGERH, as respostas da Agência e dos demais Estados são dadas de maneira informal pelos especialistas lotados na área de fiscalização, não havendo documento legal para respondê-los. Voltando ao Estado do Ceará, se o usuário outorgado quiser instalar qualquer outro tipo de medidor que não seja o pré-estabelecido pelo órgão gestor, passa pelo mesmo caso dos demais Estados, ou seja, não há norma legal que estabeleça qual medidor pode (ou não) ser instalado.

\subsection{A NECESSIDADE DE MEDIÇÃO DE VAZÃo}

Conforme explanado anteriormente, a ANA e a maioria dos órgãos gestores de recursos hídricos estaduais exigem que os usuários outorgados devam implantar e manter em funcionamento equipamentos de medição para monitoramento contínuo da vazão utilizada. Em contrapartida, o CNRH, órgão máximo que abrange os recursos hídricos de domínio estadual e da União, exige que o outorgado deva implantar um monitoramento da vazão captada e/ou lançada e da qualidade do efluente. Em outras palavras, se um usuário preenche uma caderneta com as horas de utilização de uma bomba e conhece o valor nominal máximo de vazão 
da bomba, monitora o volume utilizado e atende à exigência do CNRH, sem ter de necessariamente instalar equipamento de medição de vazão.

Antes de entrar no mérito de obrigar ou não o usuário outorgado a medir o volume outorgado, cabe evidenciar a diferenciação entre outorga e uso de recursos hídricos.

No ato da outorga, o órgão gestor de recursos hídricos autoriza um ou mais usuários a utilizar determinado volume de água, baseado nas informações de como o empreendimento irá funcionar. Nesse caso, utiliza-se um método indireto para o cálculo do consumo da água. Exemplificando, no caso da irrigação, essa estimativa é feita normalmente utilizando vários fatores, como o método adotado (aspersão, pivô, gotejamento, etc.), a precipitação e a evaporação na região, a área a ser irrigada, o tipo de cultura, dentre outros.

Já o uso de recursos hídricos é o real volume utilizado, podendo ser calculado de várias formas, como por medição de vazão feita por equipamento, acumulada a determinado tempo, ou por estimativa de volume considerando dados da bomba utilizada para captação, associada ao tempo de utilização da mesma.

Portanto, a vazão outorgada pode ser considerada um valor máximo a ser utilizado por meio de parâmetros indiretos, enquanto o uso de recursos hídricos é uma estimativa real do volume consumido.

Carolo (2007) afirma que a outorga é concedida pelo órgão gestor de recursos hídricos após avaliar a compatibilidade entre as demandas hídricas existentes e a disponibilidade hídrica (oferta) do corpo de água, levando em conta as finalidades do uso e os impactos causados nos recursos hídricos.

Sendo assim, no que tange ao órgão gestor para emissão de novas outorgas, considera-se a disponibilidade de água existente levando em conta os volumes já outorgados. No entanto, a realidade pode se apresentar bem diferente do mundo legal. Por exemplo: pode haver usuário outorgado que sequer utilize uma gota de água. Se ainda estiver na fase de planejamento e instalação de seu empreendimento, o usuário está amparado legalmente pela Resolução 16 do CNRH, de 2001, estabelecendo que qualquer usuário outorgado tem prazo de dois anos para início da implantação do empreendimento objeto da outorga (Brasil, 2001). 
Complementando o exemplo acima, dependendo da bacia, em casos de escassez de água no trecho, o quantitativo outorgado pode ser realocado para outros usos, passado o período de dois anos da outorga. Infere-se, nessa situação em específico, uma especulação do empreendimento outorgado, vindo a obter vantagens futuras por possuir uma propriedade "com outorga". Daí a importância de o órgão gestor conhecer o real uso, não somente àquele outorgado.

Ainda na linha de regiões com escassez hídrica, pode ser que o usuário solicite um valor outorgado inferior ao que realmente utiliza, valor esse que "passaria" pelo crivo de alocação de água determinado pelo órgão gestor ou comitê de bacia dessas regiões. Daí, é mais importante ainda o controle do uso, uma vez que essa água a mais realmente captada pelo usuário, e não prevista legalmente, não estará disponível para outros usuários a jusante.

Outro caso que pode ocorrer é o de um usuário solicitar um volume outorgado bem superior ao que realmente irá utilizar, com fim de conseguir um maior financiamento bancário. Nos empreendimentos de irrigação, por exemplo, onde um banco exija que o empreendedor apresente a outorga de direito de uso para liberação do financiamento para aquisição de maquinários, o empreendedor apresenta outorga com valor superior ao que realmente vai utilizar para receber o financiamento, e não implementa de fato o que foi planejado.

Do raciocínio traçado, delineiam duas importâncias para o órgão gestor em se conhecer o real uso da água em determinada região: saber se o volume outorgado para cada usuário está de acordo com a realidade do seu uso, de forma particular, e quanto das demandas hídricas naquela região corresponde ao total outorgado, de maneira geral.

Surgem então as seguintes questões: quando o usuário precisa medir o volume utilizado? E se precisa medir, qual deve ser o instrumento recomendado para realizar as leituras de vazão? Antes de responder essas perguntas, imaginem-se quatro situações hipotéticas, onde determinado usuário solicita outorga para captação de 1 1/s:

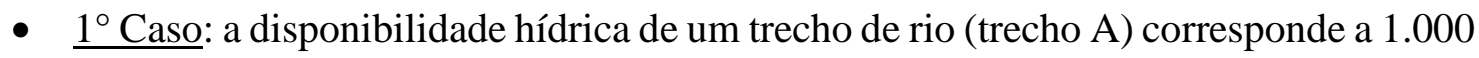
1/s, não havendo outros usuários no trecho citado.

- $\quad \underline{2}$ Caso: a disponibilidade hídrica de um trecho de rio (trecho B) corresponde a 100 1/s, não havendo outros usuários no trecho citado. 
- $\quad \underline{3^{\circ} \text { Caso: }}$ a disponibilidade hídrica de um trecho de rio (trecho C) também corresponde a 100 l/s, só que já existem outros usuários outorgados no trecho, totalizando 89 1/s de vazão outorgada. Acrescentando 1 1/s do novo pedido, tem-se 90 1/s de vazão autorizada para captação.

- $4^{\circ}$ Caso: a disponibilidade hídrica de um trecho de rio (trecho D) corresponde a 10 1/s, não havendo outros usuários no trecho citado.

Em resumo, pode-se construir a seguinte tabela:

Tabela 3.1- Casos hipotéticos de disponibilidade hídrica em trechos de rio

\begin{tabular}{|c|r|r|r|r|r|}
\hline $\begin{array}{c}\text { Trecho } \\
\text { do rio }\end{array}$ & $\begin{array}{c}\text { Disponibilidade } \\
\text { hídrica }\end{array}$ & $\begin{array}{c}\text { Vazão já } \\
\text { outorgada }\end{array}$ & $\begin{array}{c}\text { Novo pedido } \\
\text { de outorga }\end{array}$ & $\begin{array}{c}\text { Total de uso } \\
\text { no trecho }\end{array}$ & $\begin{array}{c}\text { Comprometimento } \\
\text { de uso no trecho (\%) }\end{array}$ \\
\hline Trecho A & $1.000 \mathrm{l} / \mathrm{s}$ & -- & $11 / \mathrm{s}$ & $11 / \mathrm{s}$ & $0,1 \%$ \\
\hline Trecho B & $100 \mathrm{l} / \mathrm{s}$ & -- & $11 / \mathrm{s}$ & $11 / \mathrm{s}$ & $1,0 \%$ \\
\hline Trecho C & $100 \mathrm{l} / \mathrm{s}$ & $891 / \mathrm{s}$ & $11 / \mathrm{s}$ & $901 / \mathrm{s}$ & $90,0 \%$ \\
\hline Trecho D & $10 \mathrm{l} / \mathrm{s}$ & -- & $11 / \mathrm{s}$ & $11 / \mathrm{s}$ & $10,0 \%$ \\
\hline
\end{tabular}

A partir da tabela 3.1, verifica-se que não há outros usos nos trechos A, B e D, e o pedido de outorga de 1 1/s de um usuário nesses trechos irá ser influenciado pelo porte do rio. No trecho A, de maior porte, a captação de 1 1/s compromete $0,1 \%$ de uso; no trecho $\mathrm{B}$, de porte intermediário entre $\mathrm{A}$ e $\mathrm{D}$, compromete $1,0 \%$ do uso; e no trecho $\mathrm{D}$, de menor porte, $10 \%$ do uso fica comprometido. Nesses três trechos, pode-se averiguar que, individualmente, há mais importância em se conhecer o real uso do usuário instalado no trecho $\mathrm{D}$ do que o no trecho B e do que no trecho A. Pode-se denominar essa influência como comprometimento individual.

Já fazendo uma comparação entre os trechos B e C percebe-se que a disponibilidade hídrica é a mesma, de 100 1/s. O que difere é que em B não há usos outorgados e que em C há 89 1/s outorgados; com a entrada do novo usuário serão 90 1/s. Tem-se aqui o caso de um comprometimento coletivo do trecho a ser analisado.

Seria necessária uma exigência de instalação de equipamento de medição de vazão no trecho A, ou mesmo no trecho B? Não seria razoável exigir somente que o usuário do possa monitorar sua vazão captada? Já no trecho $\mathrm{C}$, que tem usos outorgados próximos à disponibilidade hídrica, não é pertinente a instalação de um equipamento de medição para conhecer o real 
uso dos principais empreendimentos ali outorgados? Por fim, no trecho D, como determinado usuário já compromete o uso individualmente de forma significativa, não é interessante exigir a instalação de equipamento para melhor conhecimento do uso?

As respostas às perguntas anteriormente feitas passam por uma análise das variáveis que compõem um sistema de oferta e demanda de um corpo hídrico, e de como essas se relacionam para verificar a necessidade do controle de vazões. Apresenta-se, a seguir, a definição de cada uma dessas variáveis.

\subsubsection{Tipo de interferência}

Em relação à captação, o usuário de recursos hídricos pode retirar a água de um corpo d'água de duas formas: por bombeamento ou por gravidade. No $1^{\circ}$ caso, há utilização de energia para a retirada da água, pela utilização de motor movido a energia elétrica ou combustível (diesel), com trecho de tubulação fechada (conduto sob pressão). Já no $2^{\circ}$ caso, a gravidade faz com que a água seja transportada a outro lugar dentro da propriedade do usuário, normalmente por um canal, denominado canal de chamada.

Independentemente da maneira como é captada, depois a água será aduzida (levada) à sua destinação final de duas formas: por tubulação fechada (condutos sobre pressão), aproveitando a energia do bombeamento, ou por superfície livre (canais e calhas).

Em relação ao lançamento, cabe primeiramente distinguir o lançamento pontual do difuso. Um lançamento é considerado pontual quando se restringe a um simples ponto, de modo que seja possível determinar a sua localização. Efluentes de Estações de Tratamento de Esgotos e descargas industriais são fontes pontuais. Já os lançamentos difusos caracterizam-se, por sua vez, por estarem distribuídos ao longo da superfície do solo, apresentando múltiplos pontos de descarga resultantes do escoamento em áreas urbanas e agrícolas (Souza et al., 2009). Também são considerados lançamentos não pontuais aqueles que não apresentam um ponto de lançamento específico, sendo despejados ao longo das margens dos rios ou lagos (Meneses e Tucci, 2003).

Nesta dissertação, os lançamentos difusos não serão considerados, pois não há como precisar a localização do ponto e, portanto, não há como medir. 
Sendo assim, considerando a tipologia dos lançamentos pontuais, normalmente o corpo d'água receptor está num nível mais baixo que o esgoto produzido (doméstico ou industrial), sendo conduzido pontualmente por um canal (superfície livre). Há também a possibilidade de os resíduos domésticos ou industriais serem conduzidos por tubulação fechada, até para evitarem o mau cheiro, sendo que essa tubulação normalmente não se encontra sob pressão, ou seja, comporta-se como um conduto livre.

Em relação ao tipo de interferência, o que importa é saber se, na captação, adução ou lançamento, como se dá a condução da água, seja por superfície livre ou por conduto forçado. Em resumo, tem-se:

$$
\text { Ponto de interferência }\left\{\begin{array}{c}
\text { Captação }\left\{\begin{array}{c}
\text { Superfície livre } \\
\text { Conduto sob pressão }
\end{array}\right. \\
\text { Lançamento pontual\{Superfície livre }
\end{array}\right.
$$

\subsubsection{Vazão outorgada (Qoutorga)}

Qoutorga é a vazão outorgada pelo órgão gestor de recursos hídricos, podendo ser de captação ou de lançamento. Diferentes valores podem ser considerados por determinado órgão gestor para deferir uma outorga de direito de uso, dependendo do tempo. Para melhor elucidação, toma-se como exemplo um irrigante que capta água bruta utilizando uma bomba com capacidade máxima de vazão prevista para 100 l/s, 12 horas/dia, 15 dias/mês. Com esses dados, podem ser definidos três tipos de vazão:

- Vazão máxima instantânea $\left(\mathrm{Q}_{\max }\right)$ : corresponde ao valor de vazão da capacidade máxima instalada. No exemplo, $\mathrm{Q}_{\max }=100$ 1/s.

- Vazão média diária $\left(\mathrm{Q}_{\mathrm{med} / \mathrm{dia}}\right)$ : é a vazão média captada ao longo do dia. Pelo exemplo, seria $\mathrm{Q}_{\mathrm{med} / \mathrm{dia}}=\mathrm{Q}_{\max } \times(12 \mathrm{horas} / \mathrm{dia} / 24$ horas $)=50$ l/s.

- Vazão média mensal ( $\left.Q_{\text {med/mês }}\right)$ é a vazão média captada ao longo do mês. Pelo exemplo, seria $\mathrm{Q}_{\mathrm{med} / \mathrm{mês}}=\mathrm{Q}_{\mathrm{med} / \mathrm{dia}} \times(15 \mathrm{dias} / \mathrm{mês} / 30 \mathrm{dias})=25 \mathrm{l} / \mathrm{s}$. 
Há, também, a questão da sazonalidade, que influencia em duas coisas: necessidade ou não de captação, dependendo do mês, e maior ou menor vazão captada, dependendo da demanda para produção.

Em termos de outorga, pode-se levar em conta o número de horas por dia de uso, e outorgar ao usuário uma vazão média diária. Dependendo da finalidade, com destaque para a irrigação, pode-se levar em conta também a sazonalidade, e outorgar a vazão média mensal (Bof et al., 2009).

Assim, a vazão outorgada pode ser considerada como a máxima instantânea, a média diária ou a média mensal. O máximo valor outorgado seria então:

$\mathrm{Q}_{\text {máx_outorga }}=\mathrm{Q}_{\text {máx }} \geq \mathrm{Q}_{\text {média_diária }} \geq \mathrm{Q}_{\text {média_mensal }}$

\subsubsection{Vazão de captação (Qcaptação)}

Essa variável trata do volume de água do rio que o usuário de recursos hídricos vai se apropriar em termos quantitativos, dado um determinado período de tempo. Em outras palavras, é a vazão de captação retirada do corpo d'água para consumo próprio.

Entretanto, para dimensionamento da tubulação ou canal para adução da água bruta, devese levar em conta a $\mathrm{Q}_{\max }$ vista no subitem acima, pois essa é a vazão capaz de retirar a água para o sistema, independentemente do tempo de funcionamento. Essa deve ser a vazão a ser considerada para aquisição e instalação do equipamento, se necessário. Dessa forma, para o presente trabalho, levando em conta que se considera o real uso, que pode ser superior ao outorgado, para definição quanto a uma possível instalação de equipamento de medição, a vazão de captação sempre será maior ou igual à outorgada $\left(\mathrm{Q}_{\text {captação }} \geq \mathrm{Q}_{\text {outorga }}\right)$. Explicitando melhor, a vazão de captação será equivalente à máxima instantânea constante no processo de cadastramento ou de outorga, e equivalente à capacidade de instalação do sistema. Assim:

$$
\mathrm{Q}_{\text {captação }}=\mathrm{Q}_{\text {máx_outorga }}=\mathrm{Q}_{\mathrm{máx}}
$$

\subsubsection{Vazão de diluição (Qdiluição)}

O ponto de interferência pode ser de captação, conforme visto anteriormente, ou de lançamento. No $2^{\circ}$ caso, considera-se a vazão de diluição de efluentes ( $\left.Q_{\text {diluição }}\right)$ como a parcela 
referente ao aspecto qualitativo da água. No gerenciamento de recursos hídricos, há o princípio de permitir o lançamento no corpo hídrico de uma carga máxima de poluentes, de modo que, após diluição pelo trecho de rio ou corpo d'água receptor, a qualidade da água no referido corpo d'água permaneça satisfatória. Essa condição satisfatória deve ser estabelecida para cada parâmetro relacionado à qualidade da água (Cruz, 2001).

Salim et al. (2007) definem a vazão de diluição (Q diluição) como a parcela da vazão comprometida pela emissão de determinado despejo, de forma que, após o lançamento, a concentração de cada parâmetro de qualidade de água seja igual ou inferior à concentração permitida para o trecho do curso de água.

Cabe aqui distinguir, em termos legais e de autorização, o lançamento de efluentes e a vazão de diluição. No Brasil, o lançamento em si é passível de autorização do órgão ambiental. As características da outorga de direito de uso, definidas pelo órgão gestor de recursos hídricos, de fato, não autorizam o lançamento de efluentes, mas sim o uso da água para fins de diluição dos efluentes, apropriando-se de vazões disponíveis no corpo de água para tal finalidade. Sendo assim, cabe à outorga autorizar a utilização da água do corpo receptor para diluição de efluentes e ao licenciamento ambiental autorizar a atividade de lançamento (Garcia, 2011).

Quanto aos parâmetros a serem analisados na avaliação da outorga para diluição de efluentes, Salim et al. (2007) estabelecem que devam ser considerados os poluentes que representem impactos mais significativos na bacia, ou seja, aqueles que utilizam maior quantidade de água para o decaimento ou a diluição. A avaliação do pleito de outorga deve se concentrar nos poluentes de maior impacto, enquanto que o licenciamento tem de se preocupar com todos os poluentes que impactam os usos designados. Neves (2005) corrobora que cabe à outorga garantir a disponibilidade hídrica, sendo que o licenciamento, instrumento posterior à outorga, supõe que essa disponibilidade na bacia seja suficiente para transportar os poluentes lançados.

Outra questão a ser respondida na avaliação de pleitos de outorga consiste na escolha dos parâmetros de qualidade a serem adotados. Segundo Kelman (1997), como existem muitos parâmetros, pode-se fazer um balanço para cada um deles e considerar a demanda qualitativa 
apenas a maior delas. Entretanto, o autor reconhece que, nesse tipo de abordagem, seria necessária a avaliação da disponibilidade hídrica para cada poluente, uma vez que nem todos os parâmetros seguem a mesma tendência.

Como o parâmetro adotado para análise dos pedidos de outorga nos órgãos gestores estaduais e na ANA é a Demanda bioquímica de Oxigênio - DBO, esse será o parâmetro a ser escolhido para cálculo da vazão de diluição nesta dissertação. Complementa-se aqui a escolha da DBO pelo fato desse parâmetro ser representativo de esgotos domésticos e um dos elementos mais presentes nos diferentes tipos de efluentes industriais.

Sendo assim, o cálculo para a vazão de diluição segue a fórmula proposta por Kelman (1997) e utilizada pelos órgãos gestores de recursos hídricos:

$$
\mathrm{Q}_{\text {diluição }}=\mathrm{Q}_{\text {efluente }} \times \frac{\left(\mathrm{DBO}_{\text {efluente }}-\mathrm{DBO}_{\text {permitida }}\right)}{\mathrm{DBO}_{\text {permitida }}-\mathrm{DBO}_{\text {natural }}}
$$

Onde:

Qdiluição = vazão de diluição de efluentes $(\mathrm{em} \mathrm{1/s} \mathrm{ou} \mathrm{m³/h);}$

Qefluente = vazão de lançamento do efluente doméstico ou industrial (em 1/s ou m³/h);

DBOefluente $=$ DBO tratada (ou não) do efluente doméstico ou industrial (em mg/l);

DBOpermitida $=$ DBO permitida para o corpo hídrico, dada pelo seu enquadramento; e

DBOnatural = DBO do corpo hídrico, em suas condições naturais.

Vale observar que a vazão de lançamento do efluente a ser considerada no presente trabalho $\left(Q_{\text {efluente }}\right)$ também é igual ou superior à vazão outorgada $\left(Q_{\text {efluente }} \geq Q_{\text {outorga }}\right)$. Assim, a $Q_{\text {efluente }}$ a ser considerada aqui é a capacidade instalada pelo sistema para lançamento do efluente, ou a vazão máxima instantânea $\left(Q_{\text {efluente }}=Q_{\text {máx }}\right)$, por ser a necessária para avaliar um possível tipo de equipamento a ser instalado para medição, conforme visto no subitem anterior.

Cabe observar que o valor da DBOpermitida pode variar para cada trecho de rio ou corpo d'água a ser analisado, e depende do enquadramento do referido parâmetro, visando o atendimento às metas estabelecidas e de acordo com classes de uso preconizadas na Resolução do Conselho Nacional do Meio Ambiente - CONAMA no 357, de 17 de março de 2005 (Brasil, 2005). O enquadramento é definido pelo Conselho Nacional de Recursos Hídricos ou pelos Conselhos Estaduais, dependendo da dominialidade do corpo hídrico. Não havendo 
resolução dessas entidades que definem o enquadramento do corpo hídrico, o mesmo é enquadrado pelos órgãos gestores estaduais como classe 2 , com $\mathrm{DBO}_{\text {permitida }}=5 \mathrm{mg} / \mathrm{l}$, conforme Resolução CONAMA 357/2005.

Pode-se outorgar uma DBO média do efluente tratado, que será menor ou igual à máxima medida ou estipulada no processo de outorga, a depender do tipo de efluente. Uma vez que para o presente trabalho se objetiva distinguir o real uso do uso outorgado, para estabelecimento de controle do referido uso, então também será considerada a DBOefluente como o máximo instantâneo constante no processo de cadastro ou outorga, ou seja, $\mathrm{DBO}_{\text {efluente }}=$ DBO máx_instantânea.

Finalizando, a vazão de diluição aqui definida será sempre igual ou superior aos parâmetros médios outorgados:

$$
\mathrm{Q}_{\text {diluição }}=\mathrm{Q}_{\text {máx_outorga }}=\mathrm{Q}_{\text {máx }}
$$

\subsubsection{Vazão indisponível (Qindisp.)}

Em termos qualitativos, a vazão da qual o usuário efetivamente se apodera para diluição de efluentes é denominada vazão indisponível, e corresponde à soma da vazão de diluição com a vazão do efluente lançado (Collischonn, 2014). Portanto, a vazão indisponível, também chamada de carga poluente, pode ser expressada pela seguinte equação:

$$
\mathrm{Q}_{\text {indisp. }}=\mathrm{Q}_{\text {efluente }}+\mathrm{Q}_{\text {diluição }}
$$

A vazão indisponível a ser considerada nesta dissertação será sempre igual ou superior aos parâmetros médios outorgados e corresponderá aos valores máximos instantâneos:

$$
\mathrm{Q}_{\text {indisp. }}=\mathrm{Q}_{\text {máx_outorga }}=\mathrm{Q}_{\text {máx }}
$$

\subsubsection{Vazão de demanda $\left(Q_{\text {demanda }}\right)$}

Essa variável trata do volume de água do rio que o usuário de recursos hídricos vai se apropriar, dado um determinado período de tempo. Em outras palavras, é a vazão utilizada pelo 
usuário para consumo próprio. $\mathrm{O}$ ponto de interferência pode ser de captação ou de lançamento, conforme explanado nos itens anteriores. Sendo assim, a vazão de demanda $Q_{\text {demanda }}$ pode ser expressa pela seguinte equação:

$\mathrm{Q}_{\text {demanda }}=\mathrm{Q}_{\text {captação }}$ (pto. de captação) ou $\mathrm{Q}_{\text {demanda }}=\mathrm{Q}_{\text {indisp. }}$ (pto. de lançamento)

Vale aqui lembrar que a definição da vazão de demanda a ser considerada no presente trabalho será igual ou superior aos parâmetros outorgados, pois levará em conta a capacidade instalada do sistema ou os valores máximos instantâneos:

$$
\mathrm{Q}_{\text {demanda }}=\mathrm{Q}_{\text {máx_outorga }}=\mathrm{Q}_{\text {máx_instantânea }}
$$

\subsubsection{Vazão de referência ( $Q$ referência)}

Silva et al. (2006) expressam que a vazão de referência (Qreferência) é uma variável que representa o limite superior de utilização da água em um determinado curso d'água. Em termos legais, a Resolução CONAMA 357/2005 define Qreferência como a vazão do corpo hídrico utilizada como base para o processo de gestão, tendo em vista o uso múltiplo das águas e a necessária articulação das instâncias do Sistema Nacional de Meio Ambiente - SISNAMA e do Sistema Nacional de Gerenciamento de Recursos Hídricos - SINGRH (Brasil, 2005).

Na prática, os órgãos gestores de recursos hídricos aplicam o critério de vazão de referência como definição da disponibilidade hídrica (oferta de água) que pode ser outorgada aos usuários, levando em conta também uma parcela correspondente à demanda ecológica pela água. A aplicação desse critério se constitui em procedimento adequado para a proteção dos rios, pois as alocações para derivações são feitas, geralmente, a partir de uma vazão de base de pequeno risco (Harris et al., 2000).

No caso das águas superficiais, pode ser considerado, para cada trecho de rio, um determi-

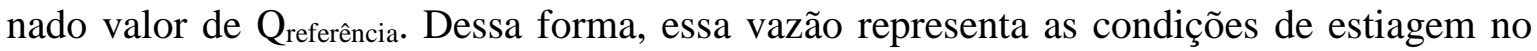
trecho de rio e serve de balizamento para avaliação do comprometimento hídrico. Q $\mathrm{Q}_{\text {referência }}$ é definida a partir de estudos hidrológicos específicos para cada bacia, considerando-se as condições hidrológicas e a infraestrutura existentes, com reservatórios. 
No Brasil, cada estado tem adotado critérios particulares pragmáticos para o estabelecimento das vazões de referência para outorga sem, no entanto, apresentar justificativas da adoção desses valores (Silva et al., 2006). Em geral, utilizam-se as seguintes vazões obtidas dos estudos hidrológicos de cada bacia:

- $\mathrm{Q}_{7,10}$ - Vazão média mínima de sete dias consecutivos com período de retorno de 10 anos;

- $\mathrm{Q}_{90}$ - Vazão com garantia de $90 \%$ de permanência dentro da série histórica de dados observada;

- Q95 - Vazão com garantia de 95\% de permanência dentro da série histórica de dados observada.

Em bacias com reservatórios e açudes, a vazão de permanência natural se modifica, sendo também chamada de vazão de regularização. A vazão regularizada pode ser entendida como a quantidade média anual de água que pode ser fornecida por um açude com uma determinada segurança de tempo.

Como exemplificação, segue tabela com os critérios de outorga adotados por alguns Estados brasileiros, utilizando $\mathrm{Q}_{7,10}$, $\mathrm{Q}_{90}$ e vazão regularizada. 
Tabela 3.2- Critérios de outorga de direito de uso da água em alguns Estados brasileiros (Benetti et al., 2003).

\begin{tabular}{|c|c|c|c|}
\hline Estado & $\begin{array}{l}\text { Vazão } \\
\text { referencial }\end{array}$ & Critério de outorga ${ }^{*}$ & $\begin{array}{l}\text { Vazão ecológica } \\
\text { indiretamente estabelecida }\end{array}$ \\
\hline PR & $7 Q_{10}$ & $50 \%$ da vazão referencial & $50 \%$ da $7 Q_{10}$ \\
\hline \multirow[t]{4}{*}{ MG } & \multirow{4}{*}{$-Q_{10}$} & $30 \%$ da vazão referencial em cursos de água usıais & $70 \%$ da $7 Q_{10}$ \\
\hline & & Quando o interessado promover regularização, olimite podeń ser supenor & \\
\hline & & descle que sejamantida uma vaz̃o residual de $70 \%$ da vazão referencial & \\
\hline & & $\begin{array}{l}\text { Poderão ser adotadas vazões residuais inferiores a } 70 \% \text { quando for } \\
\text { de interesse público e não causar prejuizos a terceiros }\end{array}$ & $\begin{array}{l}\text { Exceção à regra, quando } \\
\text { for do interesse público }\end{array}$ \\
\hline \multirow[t]{2}{*}{$\mathrm{PE}$} & & $\begin{array}{l}80 \% \text { da vazão referencial quando não houver barramento, ou quando } \\
\text { houver barramento em cursos de águra perenes }\end{array}$ & $20 \% \mathrm{da} \mathrm{Q}_{90}$ \\
\hline & $Q_{90}$ diário & $\begin{array}{l}95 \% \text { da vazão referencial quando houver barramento em cursos de } \\
\text { água intermitentes }\end{array}$ & $5 \%$ da $Q_{90}$ \\
\hline \multirow[t]{8}{*}{$\mathrm{BA}$} & & $80 \%$ da vazão referencial quando não houver barramento ou quando & $20 \% \mathrm{da} \mathrm{Q}_{90}$ \\
\hline & & $\begin{array}{l}\text { houver barramento em cursos de água perenes } \\
95 \% \text { da vazão referencial gurando houver barramento em cursos de }\end{array}$ & \\
\hline & & agua intermitentes & $5 \% \mathrm{da} \mathrm{Q}_{90}$ \\
\hline & & $\begin{array}{l}\text { Quando o suprimento for para abastecimento humano, o percentual } \\
\text { pode atingir } 95 \% \text { da vazão referencial }\end{array}$ & \\
\hline & & No caso de vazòes regulanzadas por reservatórios, a vazio residual de $20 \%$ & $20 \% \mathrm{da} \mathrm{Q}_{90}$ \\
\hline & & da vazão referencial deve escoar para jusante por descarga de fundo & \\
\hline & & ou por quakquer outro dispositivo que não inclua bombas de recalque & \\
\hline & & $\begin{array}{l}\text { Nenhum usuário individualmente receberá outorga superior a 20\% } \\
\text { da vazão referencial em um dado manancial }\end{array}$ & \\
\hline $\mathrm{PB}$ & Vazão regularizada & $90 \%$ da vazão referencial & $10 \% \mathrm{da} \mathrm{Q}_{90}$ \\
\hline $\mathrm{RN}$ & com $90 \%$ de & $90 \%$ da vazão referencial & $10 \%$ da $Q_{90}$ \\
\hline $\mathrm{CE}$ & garantia & $\begin{array}{l}90 \% \text { da vazão referencial em cursos de águra com barramento; em } \\
\text { lagos ou lagoas, } 33 \% \text { da vazão referencial }\end{array}$ & $10 \%$ ou $67 \%$ da $Q_{90}$ \\
\hline
\end{tabular}

\subsubsection{Porte do rio}

O porte do manancial pode ser considerado um fator importante pela capacidade de reservação de água, sendo utilizado como critério para definir as vazões a serem outorgadas aos usuários.

Collischonn\&Lopes (2009) criaram um sistema de suporte à decisão para análise de outorgas na bacia do rio Paraná, denominado Sistema de Controle de Balanço Hídrico (SCBH), tendo sido aprimorado por Collischonn (2014). Nesse sistema, o porte do rio é levado em conta, sendo feitas considerações gradativas para as vazões dos usuários de recursos hídricos:

- Em rios de menor porte, onde é maior a possibilidade dos diversos usuários ligarem suas bombas de forma praticamente simultânea, são consideradas, para fins de análise de outorga, as vazões máximas instantâneas dos usuários;

- Em rios de maior porte, esse procedimento pode ser considerado excessivamente conservador, sendo mais adequado o uso de médias diárias, pois o amortecimento 
natural decorrente da propagação das vazões no rio acaba por diminuir o impacto de captações mais distantes;

- Em grandes reservatórios (ex. Furnas, Marimbondo), adota-se o uso da vazão média mensal, pois estes possuem alta capacidade de regularização.

De qualquer forma, no SCBH, a escala temporal de análise é de livre escolha do técnico que analisa a outorga (Collischonn, 2014).

Levar em consideração a temporalidade da vazão pode ser um critério interessante e menos conversador para análise das vazões a serem outorgadas. Entretanto, para a medição de vazão, é importante o alcance da capacidade instalada no empreendimento, ou seja, Qmax. Só se pode chegar ao real valor utilizado pelos usuários com equipamentos que permitam medir a vazão máxima instantânea. Sendo assim, para a presente dissertação, adotar-se-á Q $\mathrm{Q}_{\max }$ como a vazão a ser utilizada para critérios de medição, conforme descrito em 3.2.2.

Finalizando, é importante que o porte do rio seja levado em conta como critério para definição de significância do conhecimento real do uso. Isso porque, um empreendimento de certa magnitude pode influenciar em termo de vazão de consumo num trecho onde o porte do rio é pequeno, e em outro trecho onde o porte do rio é maior, com maior capacidade de diluição.

\subsubsection{Comprometimento individual}

O comprometimento individual é a relação entre duas variáveis: a vazão outorgada ao usuário com a vazão de referência do trecho de rio ou reservatório. Representa, assim, o quanto um usuário individual usa da disponibilidade hídrica local. Intuitivamente, quanto maior o comprometimento individual, maior a necessidade de controle real do uso derivado individualmente. Sendo assim, em termos percentuais, apresenta-se o Indicador de Comprometimento Individual (ICI) como:

$$
\mathrm{ICI}=\mathrm{ICI}_{\text {outorga }}=\frac{\mathrm{Q}_{\text {outorga }}}{\mathrm{Q}_{\text {referência }}}
$$

Cabe aqui explicitar que um órgão gestor não concederá outorga a um usuário com vazão superior à vazão de referência por ele adotado. Assim, $0 \leq \mathrm{ICI}_{\text {outorga }} \leq 100 \%$. 
O ICI é um indicador adotado como critério para análise de outorgas pelo SCBH, conforme descrito em Collischonn (2014). A Resolução ANA nº 1041, de 19 de agosto de 2013, que define os critérios para análise de balanço hídrico em pedidos de outorga na ANA, adota o comprometimento individual como um indicador para critério de outorga (Brasil, 2013). No caso da Agência, adota-se que os pedidos de outorga devem ser restituídos ou indeferidos, nos casos em que o indicador comprometimento individual seja superior a $20 \%$.

Uma vez que a vazão de demanda ( $Q_{\text {demanda }}$ - item 3.2.6) corresponde à vazão de captação ou à vazão indisponível (lançamento) correspondente aos valores máximos instantâneos, então para o presente trabalho será considerado que um Indicador de Comprometimento Individual Máximo ( ICI $_{\text {máx }}$ ) como uma relação estabelecida entre a vazão de demanda e a vazão de referência, sendo este maior ou igual ao comprometimento individual outorgado. Tem-se então:

$$
\mathrm{ICI}_{\text {máx }}=\mathrm{ICI}_{\text {demanda }}=\frac{\mathrm{Q}_{\text {demanda }}}{\mathrm{Q}_{\text {referência }}}
$$

Neste caso, apesar de ser um valor relativo, teoricamente ICI $_{\text {máx }}$ pode ser maior que 1, pois a vazão de demanda, representada pela máxima instantânea, pode ser superior à outorgada e, dependendo do local instalado, superior à vazão de referência.

\subsubsection{Comprometimento coletivo}

O comprometimento coletivo representa o quanto o corpo hídrico está efetivamente comprometido com todos os usos consuntivos em um determinado trecho. Tomando a vazão de outorgada (Qoutorga), e somando a ela todas as demais vazões outorgadas a montante $\sum \mathrm{Q}_{\text {montante }}$, apresenta-se o Indicador de Comprometimento Coletivo (ICC), que representa a relação desse coletivo de vazões outorgados no trecho com a vazão de referência. Em termos percentuais, tem-se:

$$
\text { ICC }=\text { ICC }_{\text {outorga }}=\frac{Q_{\text {outorga }}+\sum Q_{\text {montante }}}{Q_{\text {referência }}}
$$

Nesse caso, a ideia é que, em bacias ou regiões onde já exista um comprometimento coletivo considerável, ou seja, onde a situação da bacia se encontra em situação de pouca disponibilidade hídrica restante, é natural que seja necessário um maior controle dos usos outorgados para averiguação do real uso da água na bacia. 
Enquanto o indicador de comportamento individual (ICI) representa o quanto um usuário representa, em termos percentuais, o comprometimento em um determinado trecho de rio ou manancial, o indicador de comportamento coletivo (ICC) representa o somatório de todas as vazões demandadas pelos usuários nesse trecho.

Collischonn (2014) também adota o indicador de comprometimento coletivo (ICC) como critério para análise de outorgas pelo SCBH. Da mesma forma, a Resolução ANA nº 1041, de 19 de agosto de 2013, também adota o ICC como um indicador para critério de outorga. No caso da Agência, esse indicador é o mais importante para gerenciamento quantitativo, representando o quanto o corpo hídrico está efetivamente comprometido com usos consuntivos em um determinado trecho (Brasil, 2013).

Seguindo a mesma lógica do ICI, um órgão gestor não concederá outorga a um usuário onde o trecho já esteja comprometido com valor superior à vazão de referência, ou seja, onde o ICC $>1$. Entretanto, há casos de outorgas condicionadas às sazonalidades, ou seja, se o rio estiver em condições favoráveis, na época de cheia, o usuário tem o direito de uso de se apropriar de vazões superiores às de época de seca, como é o caso das outorgas emitidas pela ANA para os rios Verde Grande, Verde Pequeno, Quaraí e Javaés, por exemplo. Mas na época de seca, devem diminuir as vazões apropriadas de forma tal que as vazões coletivas outorgadas num trecho não se ultrapasse a à vazão de referência, ou seja, em condições de estiagem, será obedecida a relação $0 \leq \mathrm{ICC}_{\text {outorga }} \leq 100 \%$.

Da mesma forma que se estabeleceu para o comprometimento individual, será considerado para o coletivo um Indicador de Comprometimento Coletivo Máximo (ICCmáx) como uma relação estabelecida entre a vazão de demanda do usuário e as demais vazões de demanda a montante com a vazão de referência, sendo este maior ou igual ao comprometimento coletivo outorgado. Tem-se então:

$$
\mathrm{ICC}_{\text {máx }}=\mathrm{ICC}_{\text {demanda }}=\frac{\mathrm{Q}_{\text {demanda }}+\sum \mathrm{Q}_{\text {montante }}}{\mathrm{Q}_{\text {referência }}}
$$

Neste caso, teoricamente $\mathrm{ICC}_{\text {máx }}$ pode ser maior que 1 , pelos mesmos argumentos explicados para o ICI máx. 


\subsection{SOBRE OS EQUIPAMENTOS DE MEDIÇÃO DE VAZÃO}

A vazão ou descarga, numa determinada seção, corresponde ao volume do líquido que atravessa essa seção na unidade de tempo (Azevedo Netto et al., 2002). A determinação dessa grandeza em uma das principais áreas da hidrometria. No Sistema Internacional de Unidades (SI), a vazão é expressa em $\mathrm{m}^{3} / \mathrm{s}$, que é comumente usada para expressar a vazão em rios de médio e grande porte. Na prática, para as medições de derivações para abastecimento de água, obras de irrigação, consumo industrial, e outras, utilizam-se as unidades $1 / \mathrm{s} \mathrm{ou} \mathrm{m} 3^{3} / \mathrm{h}$.

A medição de vazão pode ser feita de forma direta ou indireta. No $1^{\circ}$ caso, determina-se a grandeza vazão pela variação do volume em determinado tempo, ou seja, $\mathrm{Q}=\Delta \operatorname{Vol} / \Delta$ t. São dois os métodos utilizados para medição direta da vazão:

- Método volumétrico: baseia-se no tempo gasto para que um determinado fluxo de água ocupe ou escoe de um recipiente de volume conhecido, sendo a vazão expressa por: $\mathrm{Q}=\mathrm{V} / \mathrm{t}$ (Ramos, 2006). A aplicabilidade desse método em campo fica restrita aos casos de pequenas descargas, como fontes, riachos, bicas e canalizações de pequeno diâmetro (Azevedo Netto et al., 2002), onde há condições de canalizar e coletar toda água num recipiente de volume conhecido por um determinado período de tempo. Na prática, esse método é utilizado em laboratório de hidráulica para calibração de outros equipamentos, sendo que os recipientes para realização desses ensaios são tanques de grandes dimensões. Além dos tanques, são necessárias balanças de grande precisão para a determinação do peso da massa líquida (Frangipani, 2007).

- Método gravimétrico: consiste na pesagem de um determinado volume de água obtido em um determinado intervalo de tempo, t. O peso obtido é convertido em volume, através do peso específico do líquido (Ramos, 2006). Nesse caso, a vazão é dada por: $\mathrm{Q}=\left(\mathrm{P}_{2}-\mathrm{P}_{1}\right) / \gamma \times \mathrm{t}$, onde $\mathrm{P}_{1}$ é o peso inicial, $\mathrm{P}_{2}$ é o peso final e $\gamma$ é o peso específico do fluido. Na prática, o método gravimétrico é utilizado em laboratórios especializados para calibração de equipamentos, tal qual o método volumétrico.

Os equipamentos de medição usualmente calculam a vazão de forma indireta, ou seja, medese a velocidade média da seção transversal e multiplica-se pela área da mesma. Assim, temse: $\mathrm{Q}=\mathrm{v} \times \mathrm{A}$. 
A seguir, apresentam-se os processos ou métodos de medição existentes, classificando-os segundo o regime de escoamento: em conduto forçado (sob pressão, em conduto fechado) e à superfície livre (à pressão atmosférica, por gravidade ou em canal aberto). Foi escolhida tal divisão pelo fato de a captação dos usuários de recursos hídricos ser realizada por um desses dois regimes de escoamento.

\subsubsection{Medição em condutos forçados}

Os condutos forçados são dutos no qual o fluido escoa à plena seção e sob pressão. Os condutos de seção circular são chamados de tubos ou tubulações, e representam a maioria dos dutos que levam a água bruta bombeada do corpo d'água até a área de produção do usuário de recursos hídricos.

\subsubsection{Hidrômetros}

Azevedo Netto et al. (2002) definem os hidrômetros como aparelhos destinados à medição da quantidade de água que escoa em intervalos de tempo relativamente longos. São comumente utilizados para medir o consumo de água das instalações prediais e industriais. Podem ser classificados como hidrômetros velocimétricos (ou taquimétricos) e volumétricos.

Frangipani (2007) relata que os hidrômetros velocimétricos se baseiam em um rotor de várias pás montadas em ângulos (turbinas), diretamente ou perpendicularmente ao fluxo. A velocidade de rotação da turbina é proporcional à vazão. Já os volumétricos têm como princípio de funcionamento a passagem do fluido através de câmaras de volume perfeitamente conhecido. O próprio fluido faz a movimentação dessas câmaras, sendo o volume obtido por mecanismos que fazem a contagem do número de vezes que as câmaras se enchem e esvaziam.

Segundo Azevedo Netto et al. (2002), os hidrômetros de velocidade são mais baratos, mais simples, de reparações mais fáceis e menos sensíveis às impurezas da água. Já os hidrômetros de volume são mais precisos e mais sensíveis, indicando consumos muito pequenos. Por outro lado, os de velocidade são menos exatos e menos sensíveis, não medindo vazões muito 
pequenas, fora da faixa de utilização recomendada pelo fabricante. Os medidores volumétricos são mais caros e sofrem, sensivelmente, com eventuais impurezas na água, sendo que suas reparações são mais difíceis. Portanto, neste trabalho, consideram-se, para fins de aplicação, somente os hidrômetros velocimétricos ou taquimétricos, uma vez que essa análise se restringe a aplicações em água bruta, captada diretamente em corpos d'água superficiais que apresentam impurezas.

Os hidrômetros velocimétricos podem ser classificados em três categorias: do tipo monojato, multijato e Woltmann. Nos medidores monojato, a turbina é acionada por um único jato de água, que a atinge de modo tangencial. Já os medidores multijatos são os mais utilizados no Brasil, e possuem na câmara de medição orifícios ou fendas que fazem com que a turbina seja acionada tangencialmente por vários jatos de água. Silva (2008) relata que os hidrômetros do tipo monojato e multijato são largamente utilizados em micromedição, que pode ser entendida como a medição do volume consumido pelos clientes da companhia de saneamento, ou seja, em água tratada, com diâmetros de entrada normalmente inferiores a 50mm.

Entre os medidores taquimétricos, cabe um destaque para o hidrômetro do tipo Woltmann (vide figura 3.2). Recebe essa denominação em homenagem ao Eng. Reinhard Woltmann que, em 1790, introduziu o uso de molinetes nas medições de rios e canais. Tem seu funcionamento baseado num "molinete" ou turbina instalado dentro de um conduto fechado, atuando o fluxo na direção axial em relação ao eixo do molinete e, dependendo de sua posição de instalação em relação ao fluxo, são denominados verticais ou horizontais. São medidores de boa exatidão, baixa perda de carga e robustez. Ainda segundo Silva (2008), normalmente são fabricados em bitolas iguais ou acima de $50 \mathrm{~mm}$, para usuários industriais ou comerciais. Sendo assim, pelas últimas características descritas, os hidrômetros de velocidade do tipo Woltmann são os que mais se adéquam ao perfil dos usuários de recursos hídricos que captam água bruta. 

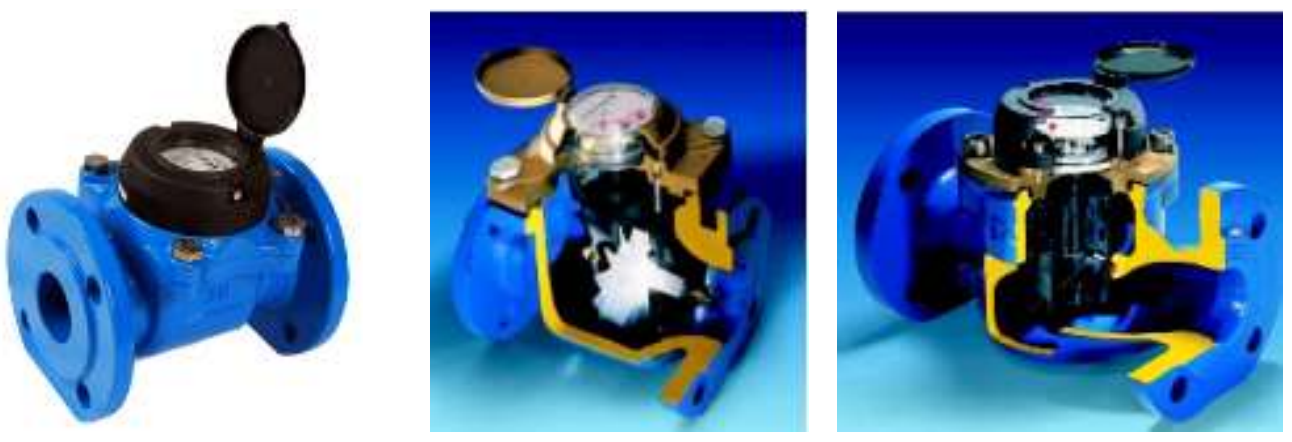

Figura 3.2 - Medidor velocimétrico tipo Woltmann (esq.), horizontal (meio) ou vertical (dir.) - Cortesia: FAE Tecnologia

Uma variação do hidrômetro Woltmann é o denominado hidrômetro tangencial, ou hidrômetro Woltmann para irrigação, que difere do primeiro pela turbina estar localizada na parte superior da cavidade onde passa a água, tendo menos contato com as partículas sólidas. Segundo três fabricantes pesquisados - Ciasey, Diehl e Hidrometer - esses hidrômetros tangenciais tem efetiva medição com até 30\% sólido em suspensão na água.
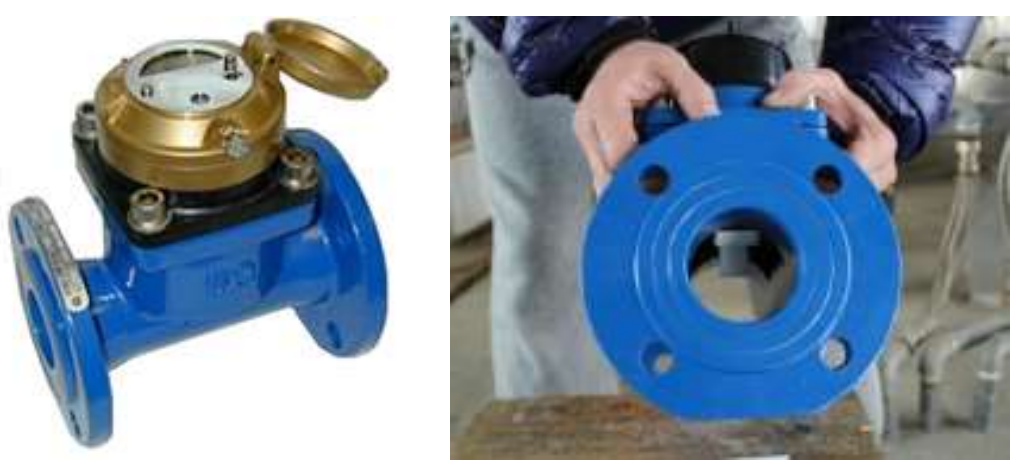

Figura 3.3 - Medidor velocimétrico tipo tangencial ou Woltmann para irrigação (esq.), horizontal (meio) ou vertical (dir.) - Cortesia: Ciasey

Todos os medidores velocimétricos apresentam o inconveniente de necessitarem de manutenção constante devido ao funcionamento através de peças mecânicas em contato direto com o fluido, sendo necessária verificação periódica de seus mecanismos móveis. Por outro lado, possuem custos relativamente baixos para tubulações de pequeno diâmetro e são fáceis de instalar. Cabe também informar que, nos catálogos dos fabricantes dos medidores Woltmann, recomenda-se a instalação de filtro de linha para diminuição das impurezas, quando utilizado em água bruta. 
As dimensões dos medidores Woltmann e tangencias variam de 50 a $300 \mathrm{~mm}$ e apresentam custos diretamente proporcionais ao seu diâmetro. Foi realizada cotação de preços com três fabricantes, sendo apresentado abaixo a média dos preços (em dólares):

Tabela 3.3- Média de preços de hidrômetros Woltmann

\begin{tabular}{|r|r|r|}
\hline Diâmetro nominal (em mm) & Preço (em US\$) & Preço (em R\$) - 14/04/2015 \\
\hline 50 & 500 & 1.500 \\
\hline 80 & 980 & 2.940 \\
\hline 100 & 1.140 & 3.420 \\
\hline 150 & 1.300 & 3.900 \\
\hline 200 & 1.480 & 4.440 \\
\hline 250 & 1.750 & 5.250 \\
\hline 300 & 3.120 & 9.360 \\
\hline
\end{tabular}

Tanto Pinto (2003) como Frangipani (2007) relatam que os hidrômetros do tipo Woltmann apresentam precisão variada de acordo com o intervalo das vazões de funcionamento, desde a vazão mínima, passando pela vazão nominal, até a vazão de sobrecarga, chegando de \pm 2 a $\pm 5 \%$. Já no catálogo de fabricantes, a curva de erro mostra que em vazões mínimas pode chegar a $-5 \%$ e, em vazões máximas, a +2\%. Guimarães (2007) realizou experimento com Woltmann instalado em água bruta e encontrou valores entre $-1 \%$ e $+2,6 \%$. Pela variação de valores, considera-se, em média, uma precisão de medida de $7 \%$.

\subsubsection{Eletromagnéticos}

O princípio básico dos medidores eletromagnéticos é semelhante ao de um gerador elétrico. Baseiam-se no princípio descoberto por Michael Faraday em 1831, em que o movimento de um fluido condutor atravessando um campo magnético induz uma tensão (Frangipani, 2007). A tensão $\tau$ pode ser expressa como $\tau=\mathrm{d} \times \lambda \times v$, onde $\mathrm{d}$ é a densidade do fluido, $\lambda$ a distância entre os eletrodos e $v$ a velocidade do fluido. Sendo $\lambda$ uma distância conhecida e $d$ uma constante (a água é um líquido incompressível), a tensão $\tau$ que se forma entre os eletrodos é diretamente proporcional à velocidade $v$ do fluido. A medida é então transmitida à unidade eletrônica, remota ou incorporada ao tubo medidor, que a transmite via sinal elétrico até a unidade de armazenamento de dados.

Comercialmente, são fabricados dois tipos de medidores eletromagnéticos para medição de vazão em condutos forçados: o do tipo carretel e o de inserção. Em relação aos eletromagnéticos de carretel, Lamon (2006) apresenta diversas vantagens para sua utilização, tais 
como: não obstrui o escoamento, não introduz perda de carga ao sistema, não possui partes móveis em contato com o fluido, sinal de saída linear e proporcional à velocidade do escoamento, alta sensibilidade gerando larga faixa de medição, alta precisão $( \pm 0,25 \%)$. Pinto (2003) afirma que a precisão varia de $\pm 0,15 \%$ a $\pm 0,5 \%$. Michalski (2001) realizou experimento denominado moving stream method (método de fluxo de movimento), estimando erro de medição em torno de 1\%. Consultando catálogos dos fabricantes Isoil, Yokogawa e Incontrol, verifica-se que o erro varia em $\pm 0,5 \%$. Considera-se, em média, uma precisão de medida de $1 \%$.

Pelos especialistas e hidrometristas, os eletromagnéticos de carretel podem ser considerados o melhor e mais confiável medidor de vazão para condutos forçados disponíveis atualmente no mercado, desde que se respeitem os critérios de instalação conforme recomendações de cada fabricante, sendo sempre necessário manter trechos retos a montante e a jusante do medidor, proporcionais ao diâmetro da tubulação, para tranquilizar as linhas de fluxo no perfil de escoamento da seção. Esses medidores ainda apresentam a vantagem adicional de possuírem custo de manutenção praticamente nulo. Há modelos que utilizam energia, e outros que funcionam com bateria interna.

Por outro lado, apresentam custos relativamente altos em relação a tecnologias mais baratas, variando diretamente com o diâmetro aplicado. Comercialmente, este equipamento é fabricado na faixa de diâmetros entre 50 e $1800 \mathrm{~mm}$. Segue tabela de preços levantada pela cotação feita com dois fabricantes, com funcionamento a bateria:

Tabela 3.4- Média de preços de eletromagnéticos de carretel a bateria

\begin{tabular}{|r|r|r|}
\hline $\begin{array}{c}\text { Diâmetro } \\
(\mathrm{em} \mathrm{mm})\end{array}$ & $\begin{array}{c}\text { Preço } \\
\text { (em US\$) }\end{array}$ & $\begin{array}{c}\text { Preço (em R\$) } \\
14 / 04 / 2015\end{array}$ \\
\hline 50 & 4.090 & 12.270 \\
\hline 80 & 4.300 & 12.900 \\
\hline 100 & 4.390 & 13.170 \\
\hline 150 & 4.840 & 14.520 \\
\hline 200 & 5.600 & 16.800 \\
\hline 250 & 7.170 & 21.510 \\
\hline 300 & 7.900 & 23.700 \\
\hline 350 & 8.640 & 25.920 \\
\hline 400 & 9.270 & 27.810 \\
\hline 450 & 11.080 & 33.240 \\
\hline
\end{tabular}

\begin{tabular}{|r|r|r|}
\hline $\begin{array}{r}\text { Diâmetro } \\
(\mathrm{em} \mathrm{mm})\end{array}$ & $\begin{array}{c}\text { Preço } \\
\text { (em US\$) }\end{array}$ & $\begin{array}{c}\text { Preço (em R \$) } \\
14 / 04 / 2015\end{array}$ \\
\hline 500 & 12.340 & 37.020 \\
\hline 600 & 13.970 & 41.910 \\
\hline 700 & 16.780 & 50.340 \\
\hline 800 & 19.480 & 58.440 \\
\hline 900 & 23.450 & 70.350 \\
\hline 1000 & 28.160 & 84.480 \\
\hline 1200 & 44.030 & 132.090 \\
\hline 1400 & 69.510 & 208.530 \\
\hline 1600 & 89.270 & 267.810 \\
\hline 1800 & 114.400 & 343.200 \\
\hline
\end{tabular}


Sua instalação requer que a linha esteja parada para que o tubo medidor possa ser conectado no local adequado. Além disso, torna-se necessário instalar peças hidráulicas adicionais, tais como flanges e juntas de expansão, caixas de concreto e blocos de ancoragem para proteção da linha e dos medidores e requer uma instalação elétrica bem cuidada, tendo-se especial atenção ao sistema de proteção contra surtos e descargas atmosféricas (aterramento).

Em relação ao medidor eletromagnético por inserção, funciona pelo mesmo princípio do anterior (Lei de Faraday), mas fazem medição de vazão num único ponto da tubulação, e deve ser um fator K para estimativa da velocidade média. Os eletrodos do medidor de inserção são inseridos na tubulação através de uma luva ou em TAP previamente instalado na tubulação. Há medidores no mercado brasileiro capazes de serem instalados com a tubulação em carga, sem necessidade de parar o fluxo para sua instalação. Pelo fato de os eletrodos estarem bem mais próximos uns dos outros, comparativamente aos medidores de carretel, esses medidores sofrem mais com interferências ou sujeira nos eletrodos. Dessa maneira, conforme descrito em catálogo de fabricantes, requerem manutenção, com inspeção e limpeza periódica dos eletrodos.

Os medidores por inserção apresentam a vantagem de que um mesmo medidor pode ser instalado em tubulações de diferentes tamanhos, podendo chegar a tubulações de $1.800 \mathrm{~mm}$ de diâmetro, assim como o carretel. Outra vantagem é que não variam de preço de acordo com o aumento do diâmetro da tubulação. Pela cotação com dois fabricantes, o preço de aquisição e instalação é de US\$ 9.750, ou R\$ 29.250 (em 14/04/2015). Em comparação com a tabela 3.2, verifica-se que o custo do medidor eletromagnético tipo carretel é mais econômico, comparativamente ao medidor eletromagnético de inserção, até o diâmetro de 400 mm. Acima dessa bitola, a tecnologia de medição por inserção torna-se mais econômica. Segue figura representativa de instalação, numa mesma tubulação, de um medidor eletromagnético de carretel e outro de inserção. 


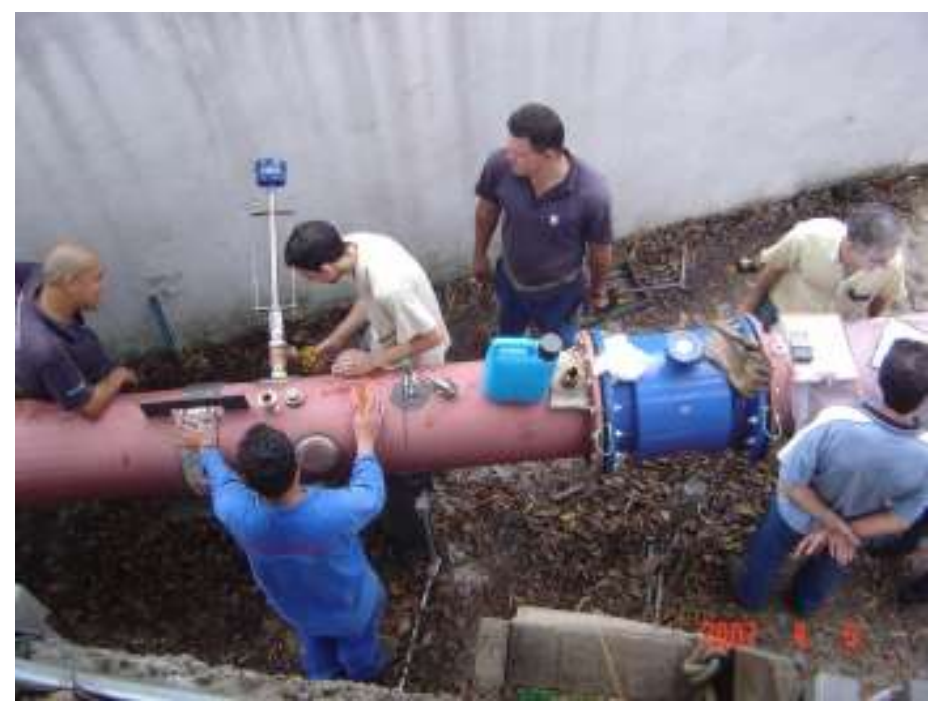

Figura 3.4 - Equipamentos eletromagnéticos de inserção (esq.) e carretel (dir.)

Os medidores de inserção fornecem sinal elétrico análogo aos de carretel, apresentando as mesmas necessidades na instalação. Entretanto, apresentam também menor precisão em relação aos de carretel, da ordem de 3 a 5\% (Lamon, 2006). Já os catálogos de dois fabricantes apresentam erro de medida variando entre $\pm 1 \%$.

Cabe aqui descrever que, de acordo com os fabricantes, deve-se tomar cuidado na inserção da haste dos eletrodos no conduto, pois declinações e posicionamentos equivocados podem comprometer a medição das velocidades do fluido.

\subsubsection{Ultrassônicos por tempo de trânsito}

O princípio físico de operação dos medidores de velocidade ultrassônicos baseia-se na propagação de ondas de ultrassom, emitidas nas frequências de $100 \mathrm{kHz}$ a $3 \mathrm{MHz}$ aplicadas no meio líquido. A velocidade sônica de propagação é uma característica própria de cada fluido e é função da densidade do mesmo, estando nas faixas de 800 a 2000 m/s (Lamon, 2006). O medidor ultrassônico pode ser de dois tipos: Doppler e tempo de trânsito (transit time). Comercialmente, os equipamentos ultrassônicos por efeito Doppler são fabricados para medição de escoamentos de superfície livre, sendo tratados em outro subitem.

Pinto (2003) descreve o método de medição de vazão tipo diferença de tempo de trânsito (transit time difference) como o método no qual a velocidade média do fluido pelo trajeto 
acústico (v) é determinada a partir da diferença do tempo de trânsito de dois sinais ultrassônicos, viajando de montante para jusante e vice-versa, cobrindo a mesma distância no fluxo do fluido. Como o diâmetro da tubulação é também uma variável conhecida, obtêm-se a vazão correspondente. Pinto (2003) também afirma que podem ser empregados em praticamente todos os tipos de água bruta, com desvio de precisão típica de \pm 1 a $2 \%$. Já Lamon (2006) relata um valor maior na faixa de erro de medição, variando de \pm 1 a $5 \%$.

Há duas formas de medição utilizando o ultrassônico por tempo de trânsito: clamp-on, onde os transdutores são instalados externamente à tubulação; e intrusivo, onde o equipamento já se encontra instalado numa tubulação pré-fabricada e flangeada, e corta-se um pedaço a tubulação antiga para a instalação do equipamento (vide figura a seguir). O intrusivo tem o inconveniente de parar a produção, seccionar a tubulação antiga e instalar o equipamento. Em compensação, a medição é mais precisa, pois o sinal ultrassônico atravessa diretamente pelo fluido; não há interferência causada pela espessura da tubulação e possíveis incrustações, como há no clamp-on. Lynnworth \& Liu (2006) fizeram um amplo estudo, com medições em tubulações de diâmetros distintos, e chegaram a resultados de precisão de $\pm 1 \%$ usando clamp-on e $\pm 0,5 \%$ pelo método intrusivo.
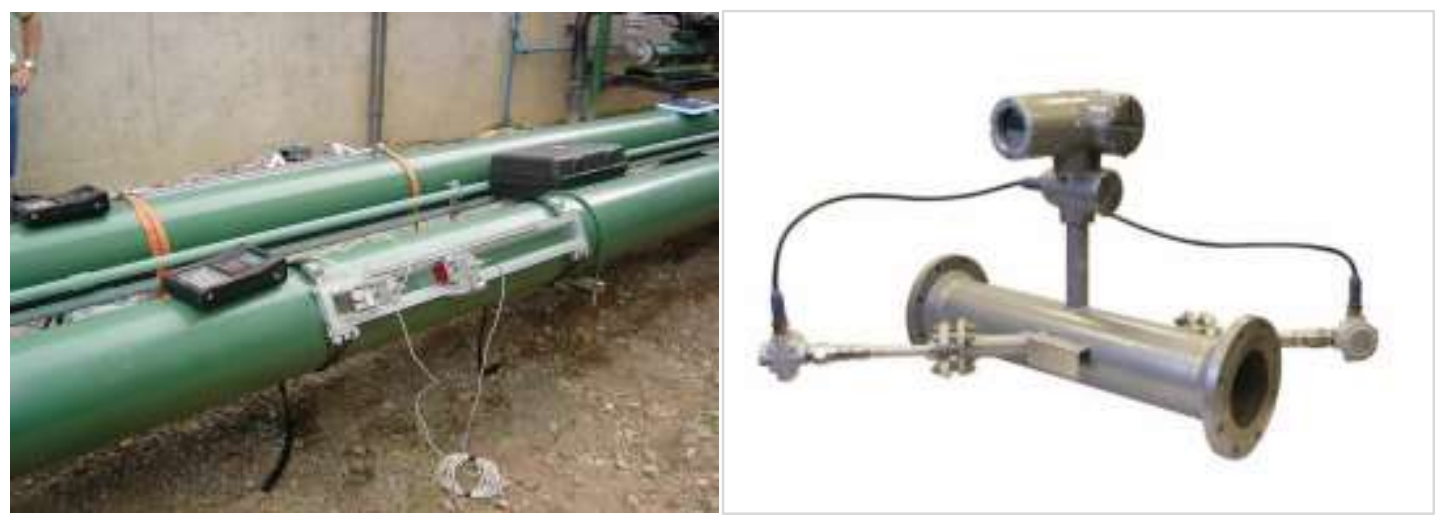

Figura 3.5 - Ultrassônico por tempo de trânsito clamp-on (esq.) e intrusivo (dir.) - Cortesia: GE Panametrics

Analogamente aos medidores eletromagnéticos, os medidores ultrassônicos por tempo de trânsito requerem instalações criteriosas mantendo-se trechos retos de tubulação, recomendados pelos fabricantes, a montante e a jusante do medidor. Os custos para aquisição e instalação desse equipamento giram em torno de US\$17.000 (R\$51.000 - 14/05/2014), de 
acordo com apreçamento feito com três fabricantes - Lamon, Incontrol e Conaut - e não dependem do diâmetro da tubulação.

\subsubsection{Diferenciais de pressão}

A melhor forma de compreender o funcionamento dos medidores diferenciais de pressão é pela aplicação da Equação de Bernoulli entre dois pontos, entre os quais tenha sido inserida uma perda de carga no sistema (Frangipani, 2007):

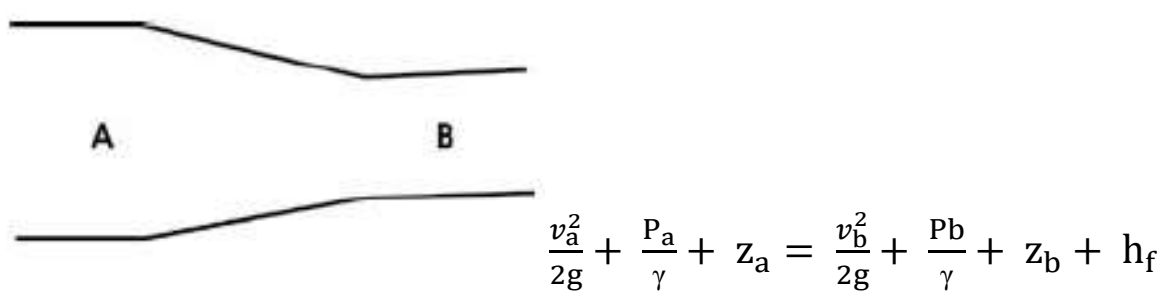

Supondo-se que os pontos A e B tenham a mesma cota e estejam suficientemente próximos, a diferença de pressão entre eles será proporcional apenas à diferença de velocidades médias do fluxo em A e B. Sendo assim, a determinação do volume de fluido que atravessa uma seção conhecida é feita por meio do diferencial de pressão entre dois pontos, formulando-se a equação geral dos medidores diferenciais: $\mathrm{Q}=\mathrm{K} \times \sqrt{ } \Delta \mathrm{P}$, sendo $\mathrm{Q}$ a vazão, $\mathrm{K}$ uma constante do medidor; e $\Delta \mathrm{P}$ o diferencial de pressão.

Frangipani (2007) relata que o valor da constante " $K$ " engloba correções devidas à seção de escoamento, aceleração da gravidade, deformações da curva de velocidades, perdas de carga no interior do medidor entre outras, sendo essa constante determinada em laboratórios ou em ensaios em campo.

São diversos os equipamentos existentes no mercado que utilizam o método diferencial de pressão para realizar medição de vazão. Os principais equipamentos são listados abaixo, com breve explanação de funcionamento, preço e precisão de medida:

Tubo Pitot e Venturi: Segundo Lamon (2006), em 1732, Henri de Pitot realizou a medição da velocidade em águas correntes, mais precisamente no rio Sena, utilizando uma versão esquemática do que hoje se conhece como Tubo de Pitot. Assim como o medidor Venturi, a medição da velocidade no escoamento se dá através da diminuição da pressão proporcional 
ao aumento da velocidade, através da redução do diâmetro, numa determinada seção. Por se tratar de um tubo com diâmetro muito menor do que o da seção onde se pretende medir a vazão, introduzido na mesma com uma extremidade recurvada em direção ao fluxo, a diferença de pressão sentida entre o interior do tubo Pitot e a tubulação, denominada h (vide Figura 3.5), será igual a $v^{2} / 2 \mathrm{~g}$, onde $v$ é a velocidade do fluxo na seção e g é a aceleração da gravidade. Assim sendo, conhecendo-se os diâmetros de ambos os tubos (Pitot e canalização), fica fácil determinar a vazão no ponto. Vale lembrar que é preciso introduzir um coefíciente de correção "c" na fórmula, de acordo com cada tubo Pitot, que deve ser aferido no campo. A medição então será obtida pela fórmula: $v=c \times \sqrt{ }(2 \times g \times h)$
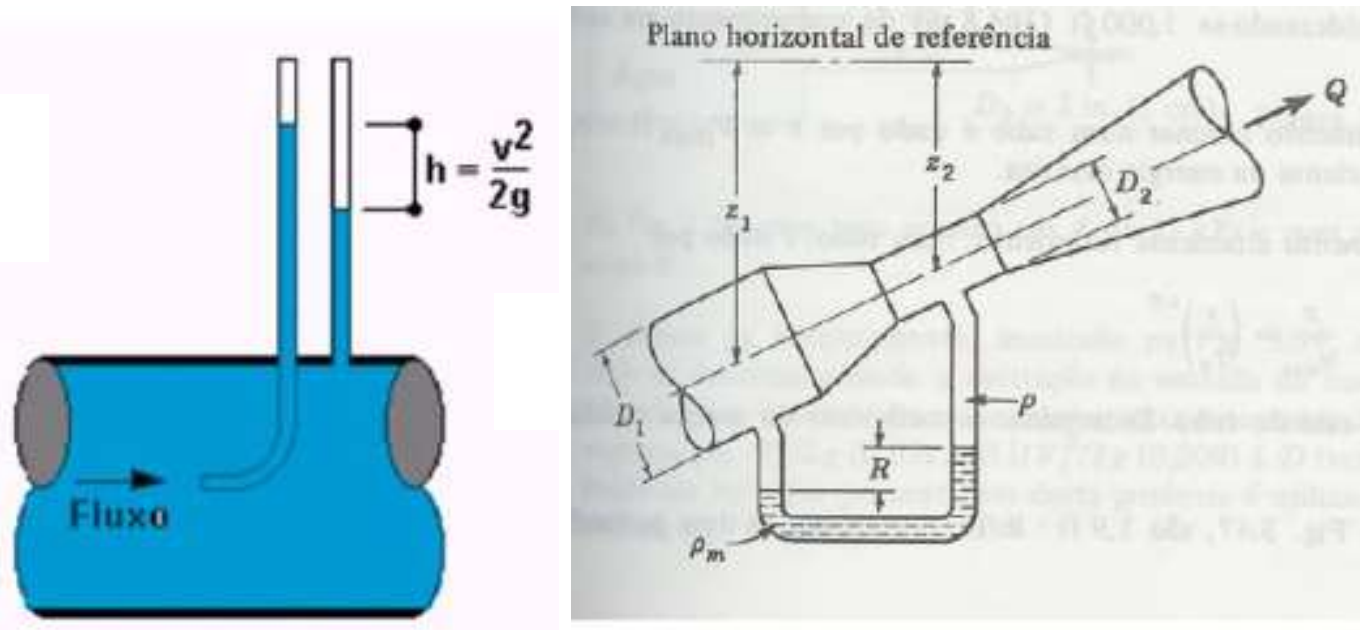

Figura 3.6 - Tubo Pitot (esq.) e Venturi (dir.) - Cortesia: Gustavo Carneiro

O tubo de Pitot pode também ser empregado em escoamento de superfície livre. Entretanto, somente leva a bons resultados no caso de correntes de grande velocidade e, sendo assim, mais empregados nas canalizações fechadas (Azevedo Netto, 2002). Além disso, por se tratar de um elemento primário sujeito a deformações ou entupimentos ao longo do tempo, o tubo deve receber inspeções e manutenções periódicas por especialistas, de maneira a garantir a confiabilidade da medição. Caso contrário, corre-se o risco das medições apresentarem desvios inaceitáveis, mesmo para casos de pequenos consumos, caso haja entupimento, obstrução ou desalinhamento do tubo, problemas normalmente difíceis de serem detectados sem manutenção periódica. 
Já o medidor Venturi foi inventado por Clemens Herschel em 1881. O nome Venturi originase do nome de um filósofo italiano que foi o primeiro hidráulico a experimentar tubos divergentes (Azevedo Netto, 2002). É um aparelho utilizado para medir vazões dentro de tubulações consistindo de um tubo com uma entrada cônica afunilando-se até uma garganta de menor diâmetro, chamada de bocal (entre $1 / 4$ e 3/4 do diâmetro da tubulação). Após o bocal, segue um trecho gradualmente divergente denominado difusor. Mede-se a queda de pressão entre o início do aparelho e o bocal e, através da equação de Bernoulli, obtêm-se: $\mathrm{Q}=\mathrm{k} \times \mathrm{m}$ $\times \sqrt{ } \Delta \mathrm{h}$, onde: $\mathrm{Q}$ a vazão; $\mathrm{k}$ o fator de correção do tubo Venturi; $\mathrm{m}$ uma constante dependente da aceleração da gravidade e das áreas das seções da tubulação e do bocal; $\Delta$ h a diferença de pressão.

Segundo recomendações dos fabricantes, o Venturi exige um trecho reto de tubulação a montante em pelo menos seis vezes o diâmetro da tubulação e todos devem ser aferidos antes de utilizados como elementos de medição.

A precisão desses equipamentos está relacionada à composição de dois elementos: o elemento primário, constituído pelo próprio tubo que provoca o diferencial de pressão, e o elemento secundário, formado pelos demais dispositivos que registram a vazão e totalizam o volume. Segundo Lamon, os erros do elemento primário são da ordem de $\pm 0,75 \%$. Já Frangipani (2007) discorre que a exatidão de tubos Venturi está diretamente relacionada ao seu projeto e cuidados construtivos, variando de valores de $1 \%$ até $4 \%$.

Comercialmente, o tubo de Pitot é mais requisitado, e utilizado em medições de vazão por companhias de saneamento. Consultando dois fabricantes - Lamon e Smar - o tubo de Pitot foi orçado em US\$12.500 ( $\mathrm{R} \$ 37.500$ - 14/05/2014), incluindo elemento secundário que faz a leitura da vazão, a bateria; e não depende do diâmetro da tubulação. O Venturi é mais utilizado em laboratórios de hidráulica e não foi possível conseguir cotação de preços aos fabricantes consultados.

Placas de orifício: o diferencial de pressão é formado pela passagem do fluido através de um orifício feito em uma placa, formando um estrangulamento na seção, conforme demonstrado na Figura 3.7. Existem três tipos de placas: as de orifício concêntrico, excêntrico e segmental, dependendo da posição do orifício em relação à seção (vide Figura 3.7). Azevedo Netto (2002) afirma que o diâmetro do orifício deve estar compreendido entre 30 e $80 \%$ do 
diâmetro da canalização. Valores inferiores a 30\% correspondem a perdas excessivas; superiores a $80 \%$ não permitem boa precisão. Em geral, variam entre 50 e $70 \%$ do diâmetro da tubulação.

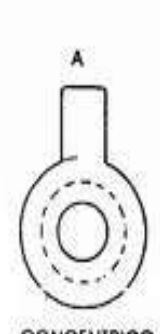

CONCENIRICO

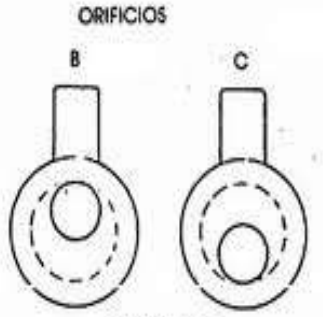

EXCENTRICO

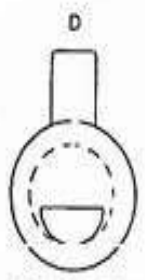

SEGMENIADO

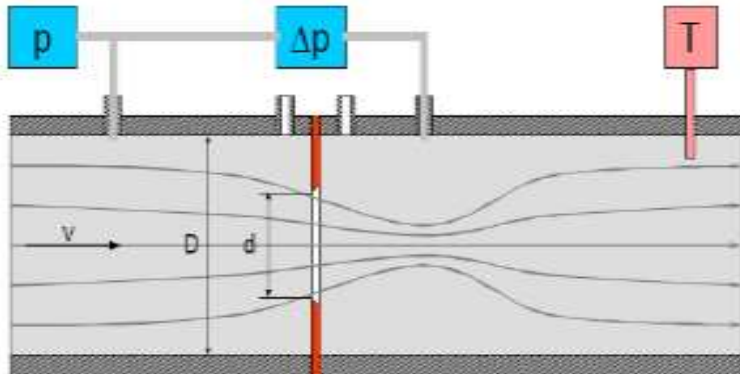

Figura 3.7 - Placas de orifício: seções transversais (esq.) e longitudinal no fluxo (dir.) Cortesia: Nilson Taira

Frangipani (2007) descreve que a exatidão das placas de orifício varia conforme os critérios de projeto utilizados, podendo variar de $0,5 \%$ até $4 \%$, apresentando relação direta com o diâmetro do furo.

Bocais: os chamados bocais de vazão têm sua característica intermediaria entre a placa de orifício e o tubo Venturi, sendo que a perda de carga residual e o custo de fabricação ficam entre esses dois elementos primários. O perfil de entrada é projetado de forma a guiar a veia até atingir a seção estrangulada do elemento de medição, seguindo uma curva elíptica ou pseudoelíptica (Vide Figura 3.8). São bastante utilizados nas indústrias para medição de vapor com alta velocidade. Azevedo Netto et al. (2002) relatam que o erro de medida varia entre 2 e $5 \%$.
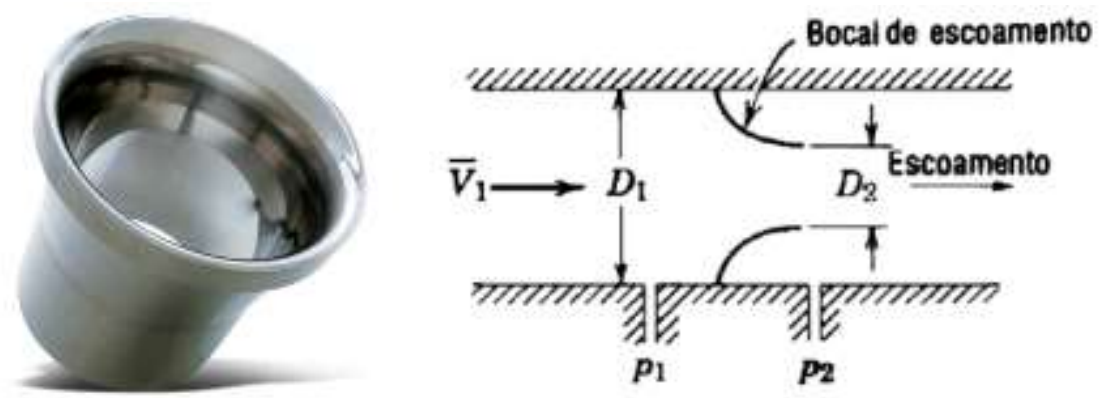

Figura 3.8 - Bocal de vazão: equipamento (esq.) e longitudinal no fluxo (dir.) - Cortesia: Prestserv

Para aquisição e instalação da placa de orifício e do bocal de vazão, o fator mais importante é o diâmetro da tubulação. Comercialmente, o bocal vazão é fabricado para diâmetros menores, de $5080 \mathrm{~mm}$, e as placas de orifício são mais utilizadas para diâmetros a partir de 
100mm. Após consulta, foi fornecido somente o preço de venda de bocal de vazão de $80 \mathrm{~mm}$, com medidor eletrônico secundário, US\$2.900 (R \$8.700 - 14/04/2015).

\subsubsection{Estimativa de vazão}

Em hidráulica, pode-se estimar a vazão de funcionamento de uma bomba por meio da elaboração de duas curvas: a curva do sistema e a curva da bomba.

A curva característica do sistema (vide Figura 3.9) é traçada levando em conta a altura necessária para vencer o desnível do ponto de captação ao ponto onde se quer que a água alcance (altura geométrica), acrescida das perdas de carga que compõem todo sistema. Essa altura total requerida, também denominada altura manométrica, é uma função crescente da vazão, uma vez que o aumento da mesma provoca um aumento das perdas de carga na tubulação. Assim, a equação do sistema pode ser descrita como $\mathrm{H}_{\mathrm{m}}=\mathrm{H}_{\mathrm{g}}+\mathrm{K}$. Q $\mathrm{Q}^{\mathrm{n}}$ (Porto, 2006), onde $\mathrm{H}_{\mathrm{m}}=$ Altura manométrica (altura requerida pelo sistema); $\mathrm{H}_{\mathrm{g}}=$ Altura geométrica (desnível a ser vencido); $\mathrm{Q}=$ vazão; $\mathrm{K}$ e $\mathrm{n}=$ constantes com valores positivos que definem a perda de carga no sistema.

Para a curva característica da bomba (vide Figura 3.9), a altura total de elevação não é constante com a vazão a ser recalcada, mas é função dela, inversamente proporcional ao aumento da vazão (Porto, 2006). Ou seja, quanto mais água (maior a vazão) se quer bombear, menor a altura que a bomba consegue lançar. Dessa forma, quando a bomba opera em conjunção com um sistema de tubulações, a energia fornecida pela bomba é igual à energia requerida pelo sistema, para a vazão bombeada.

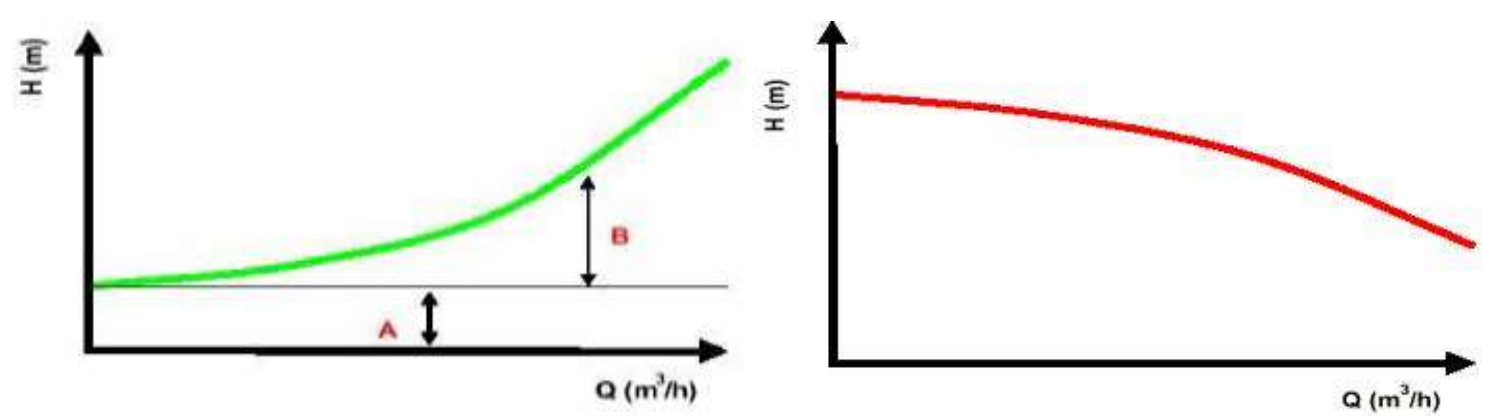

Figura 3.9 - Curva característica do sistema (esq.) e da bomba (dir.) - Cortesia: Gustavo Carneiro 
Normalmente, a solução é obtida graficamente com a sobreposição da curva característica do sistema à curva da bomba fornecida pelos fabricantes, conforme representado na figura a seguir. O cruzamento dessas curvas é denominado ponto de funcionamento ou de operação (Porto, 2006).

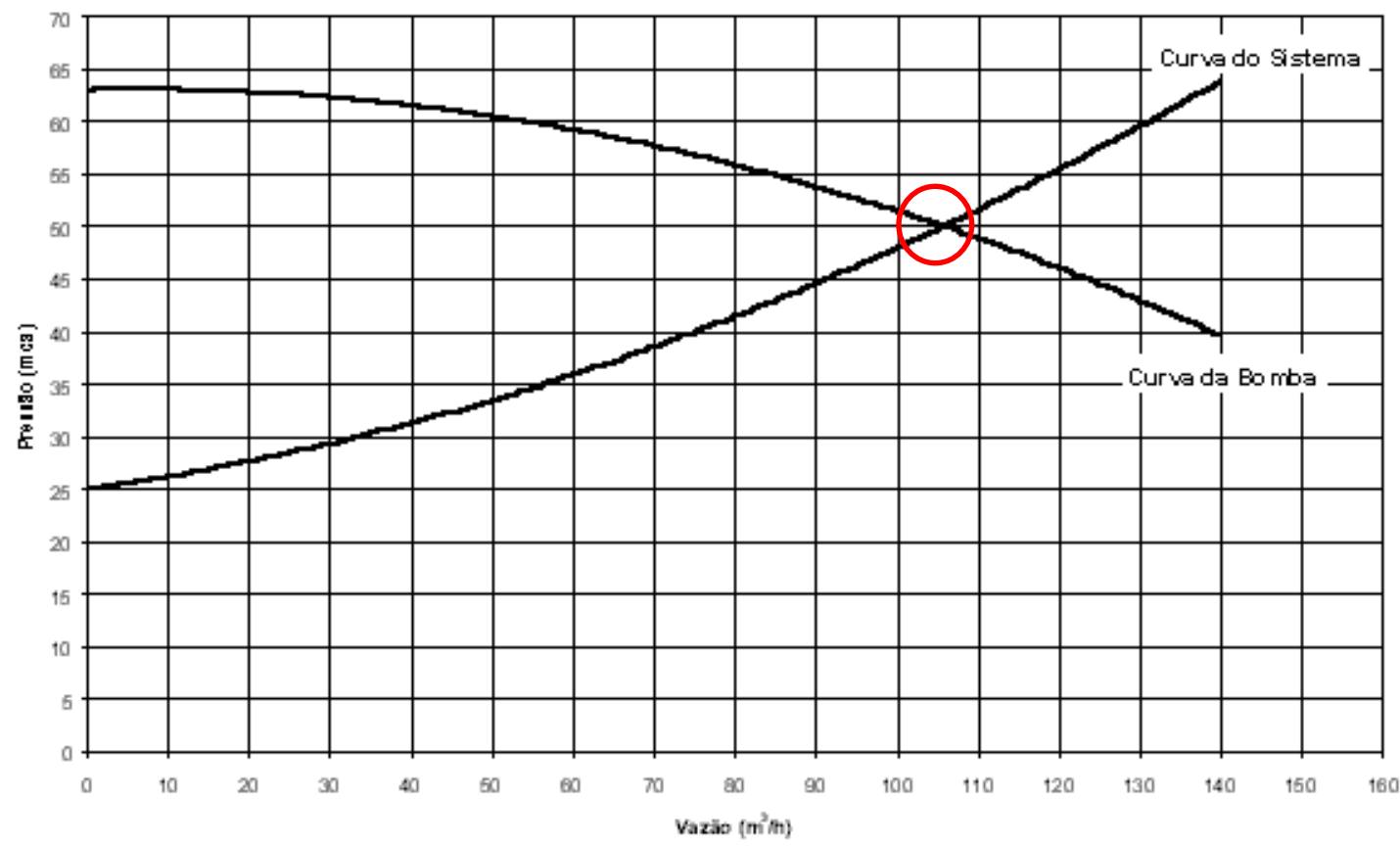

Figura 3.10 - Ponto de funcionamento ou de operação - Cortesia: Gustavo Carneiro

Nesse processo, não há medição de vazão: simplesmente faz-se uma estimativa da vazão de funcionamento, sendo que essa vazão possui um limite superior definido pela vazão nominal da bomba fornecida pelo fabricante. Dessa forma, não há como definir uma precisão de valor, mas se tem uma noção da grandeza do valor, o que pode ser razoável para usos de menor porte.

\subsubsection{Medidores do tempo}

Os equipamentos realizam medições de vazão instantâneas e, associados a um armazenador de dados, totalizam a vazão num determinado intervalo de tempo para obtenção do volume utilizado. Em geral, acoplados ao equipamento ou a um mostrador eletrônico próximo, podese visualizar a vazão instantânea e o volume total captado. 
No caso onde não há instalação do medidor de vazão, pode-se fazer a estimativa pela curva da bomba. Por outro lado, para monitorar o tempo de funcionamento da bomba, pode-se simplesmente anotar em uma caderneta a hora de ligar e desligar a bomba. Entretanto, esse tipo de monitoramento está ligado a erros humanos: informação não segura (pode ser alterada), perda ou esquecimento da anotação.

Em usuários de menor porte, onde se estabelece um limite de vazão (que pode ser a vazão nominal da bomba), torna-se importante chegar ao total de volume utilizado (horas/dias, dias/mês) por meio da instalação dos medidores de tempo: horímetro ou chave de fluxo. $\mathrm{O}$ horímetro está ligado ao tempo de funcionamento do conjunto motor-bomba. A chave de fluxo se relaciona à passagem ou não do fluxo de água pelo conduto.

Horímetro: também conhecido como temporizador, o horímetro é um dispositivo que indica o número de horas trabalhadas pelo motor ou equipamento, acumulando esse tempo de trabalho. É amplamente utilizado em indústrias, ideal para indicar o momento em que as manutenções preventivas devem ser realizadas.

Dois tipos de horímetros são encontrados no mercado: eletromecânicos (analógicos) ou digitais microprocessados, cuja leitura mostra frações de horas. Conforme demonstrado na Figura 3.11, esses aparelhos possuem um micromotor que, uma vez energizado, movimenta um conjunto numerador que mostra, em horas e centésimos de hora, o tempo durante o qual o totalizador ficou alimentado. Como não possuem nenhum sistema de reset para retornar a indicação a ZERO, o tempo indicado é o valor acumulado de vários intervalos de tempo de trabalho.

Pode-se encontrar no mercado horímetros com faixa de preço variando desde US\$30 (analógicos, mais baratos) a US\$200 (digitais, mais caros). Além do baixo custo de aquisição e instalação, os horímetros são de construção compacta e robusta e têm boa resistência a condições adversas, como intempéries (Pinto, 2003). Entretanto, por estarem ligados à parte elétrica, uma descarga maior de energia pode danificar os aparelhos, deixando de realizar a contagem do tempo e necessitando de proteção contra descargas. 

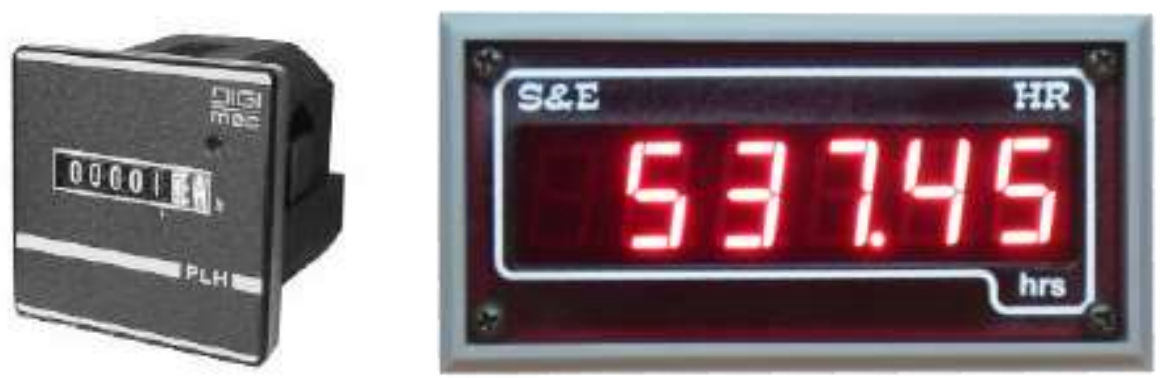

Figura 3.11 - Horímetro analógico (esq.) e digital (dir.) - Cortesia: S\&E Instrumentos

Chave de fluxo: esse instrumento tem a função de detectar se uma tubulação apresenta ou não fluxo em seu interior. Pode, ainda, acusar se houve aumento ou queda da vazão em relação a um valor pré-estabelecido. As chaves de fluxo são amplamente utilizadas pelos setores de ar condicionado, equipamentos para refrigeração e automação de bombas. Sua função principal é a de detectar se há passagem de fluxo de ar ou água, atuando na maioria das vezes como um dispositivo complementar de segurança e proteção para ligar ou desligar alarmes, motores, máquinas, sinalização em painéis de controle, etc.

Para aplicabilidade da chave de fluxo como medidor de tempo, a mesma deverá ser conectada a um armazenador ou contador, podendo ser do tipo data logger, que irá armazenar as informações de forma binária (0 não passa fluxo, 1 passa). Existem dois tipos de chave de fluxo no mercado: do tipo palheta e do tipo pistão.

A chave de fluxo do tipo palheta é composta basicamente por um invólucro, onde se encontra o contato elétrico e o sistema mecânico de acionamento, uma pequena haste e uma palheta de metal. Essa palheta tem a função de detectar a presença de fluxo no interior do tubo ao se opor ao seu movimento, provocando a atuação do contato. Uma mola localizada no interior do invólucro e conectada à haste faz com que a palheta retorne à posição original na ausência de fluxo. O interior do invólucro está totalmente isolado da parte em contato com o meio (palheta). Como vantagem, além de diferentes tamanhos de palheta, esse equipamento não necessita de alimentação elétrica para sua operação.

Os fabricantes recomendam a instalação da chave de fluxo em um trecho reto da tubulação de pelo menos 5 x D.I. (cinco vezes o diâmetro interno) a montante e a jusante. Além disso, sua instalação não deve ocorrer próxima a válvulas, curvas, reduções ou qualquer outro obstáculo que possa comprometer o desenvolvimento normal do fluxo, ou seja, ocorrência de 
refluxo que neutraliza a ação da chave ou oscilação que provoca o liga-desliga contínuo. Pode ser instalada em tubulações verticais, tanto com fluxo ascendente como descendente. Encontram-se chaves de fluxo do tipo palheta com faixa de preço variando desde US\$100 a US\$300.

Na chave de fluxo do tipo pistão, a passagem do líquido pelo sensor provoca o deslocamento preciso de um pistão magnético que detecta aumento ou diminuição do fluxo. Foi desenvolvida para uso nas áreas de ar condicionado, segurança de incêndio, indústrias químicas, mecânicas e plásticas, assim como no controle de tratamento de água de piscina ou em qualquer situação em que se necessite ligar ou desligar um equipamento na presença ou não de fluxo. Os valores de preço no mercado variam de US\$150 a US\$700.
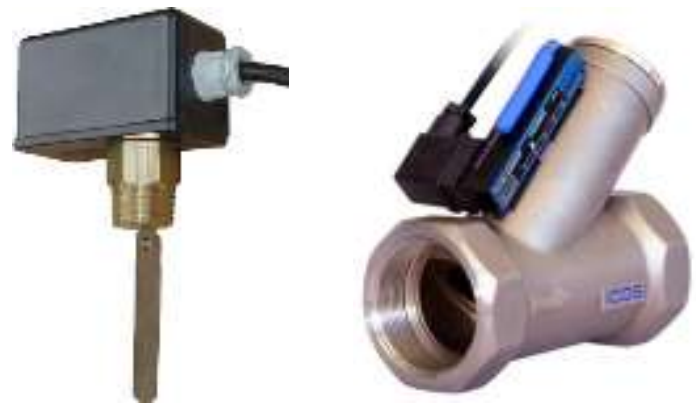

Figura 3.12- Chave de fluxo do tipo palheta (esq.) e pistão (dir.) - Cortesia: Nivetec

De uma maneira geral, por questões de preço e aplicabilidade para verificação do fluxo de água em bombas, a utilização de chave de fluxo do tipo palheta é mais vantajosa que a de pistão. Além disso, a chave do tipo palheta é produzida pelos principais fabricantes de equipamentos de medição no Brasil, como a Conaut, Incontrol e Nivetec.

As vantagens da chave de fluxo são: fácil instalação, não necessita de alimentação elétrica, quase não precisa de manutenção. Como desvantagens, tem-se: necessidade de haver trecho reto na tubulação para correta instalação, não totaliza o tempo de passagem do fluxo e deve estar acoplada a um armazenador, o que faz aumentar seu custo.

\subsubsection{Medição em superfície livre}

Um escoamento com superfície livre tem como fronteira superior a superfície livre do próprio líquido, em contato com a atmosfera ou outro meio gasoso, como é o caso das calhas e 
dos canais. Pode ocorrer, também, em condutos fechados onde o líquido não preenche totalmente a seção. Em qualquer um dos casos, a linha de pressão do escoamento, também denominada linha piezométrica, coincide com o perfil da superfície livre, estando submetida somente à pressão atmosférica.

\subsubsection{Medidor ultrassônico de vazão por Efeito Doppler:}

O efeito Doppler foi descoberto em 1842 e é utilizado em sistemas de radar (no ar) e sonar (na água), além de estudos médicos e biológicos (Lamon, 2006). O processo baseia-se no fato de que a quantidade e qualidade tonal, ou da frequência, variam em relação a um observador estático quando o alvo está parado ou em movimento (para esse caso, o fluido cuja vazão será medida). Quando a emissão ultrassônica é projetada no fluido, necessariamente com partículas sólidas em suspensão, uma parte dessa frequência é refletida (pelas partículas) de volta para o sensor, que o detecta com uma frequência ligeiramente diferente da original, pelo fato dessas partículas estarem em movimento, com velocidade igual à do fluido. Esse desvio de frequência (denominado desvio Doppler) é diretamente proporcional à velocidade do escoamento.

Suas limitações devem-se ao fato de que o fluido em escoamento deve, necessariamente, apresentar sólidos em suspensão ou bolhas de ar (que, eventualmente, podem ser injetadas em água limpa) e velocidade de escoamento suficiente para manter esses sólidos ou bolhas dispersas e em movimento da corrente (sem decantação). Podem, entretanto, medir a vazão em tubulações parcialmente cheias. Pinto (2003) recomenda a instalação desses medidores apenas para medições de vazão em condutos forçados ou de superfície livre escoando água bruta, efluentes industriais ou esgotos domésticos, todos com sólidos em suspensão ou bolhas de ar.

São diversos os tipos de equipamentos por efeito Doppler, que podem medir vazão em canais e tubos, instalados de forma fixa, conforme Figura 3.13 a seguir. Podem também serem aparelhos portáteis, utilizados para medição a vau em pequenos rios ou canais (vide Figura 3.13). Finalmente, esses equipamentos podem ser acoplados a uma embarcação para medição de vazão em rios de médio e grande porte, de acordo com a Figura 3.14. 

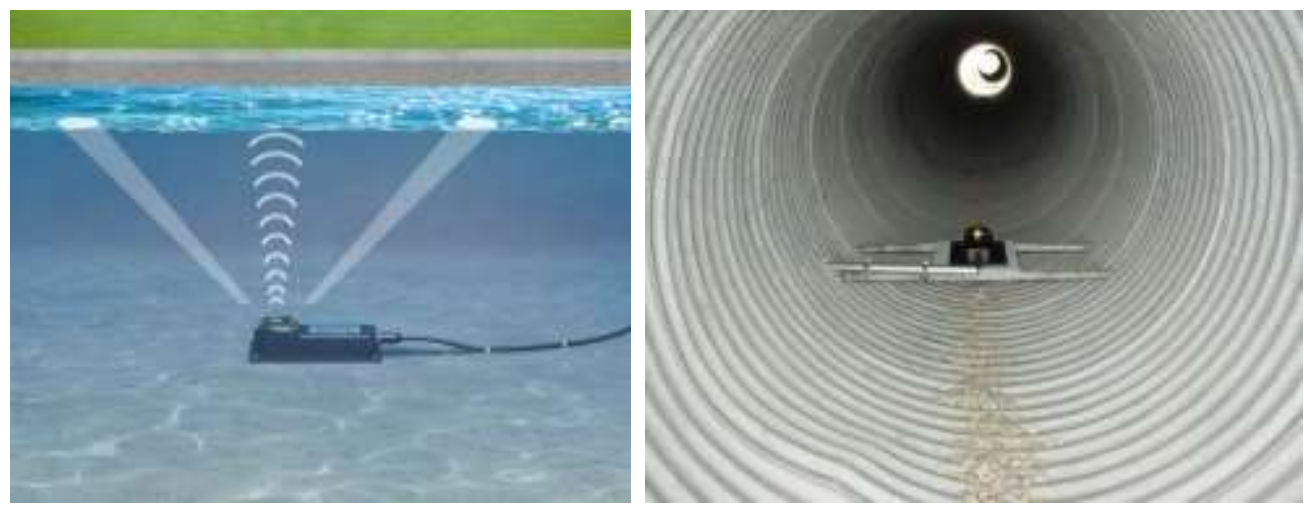

Figura 3.13- Ultrassônicos tipo Doppler em canais abertos (esq.) e dutos fechados (dir.) Cortesia: Sontek
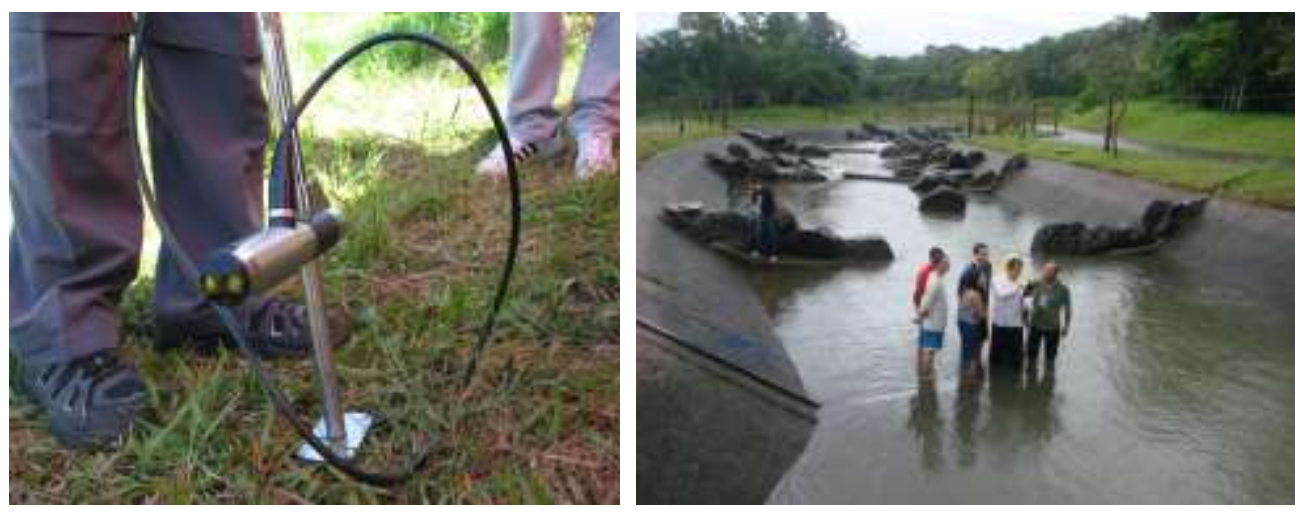

Figura 3.14 - Medição a vau com ultrassônicos tipo Doppler (Flowtracker)
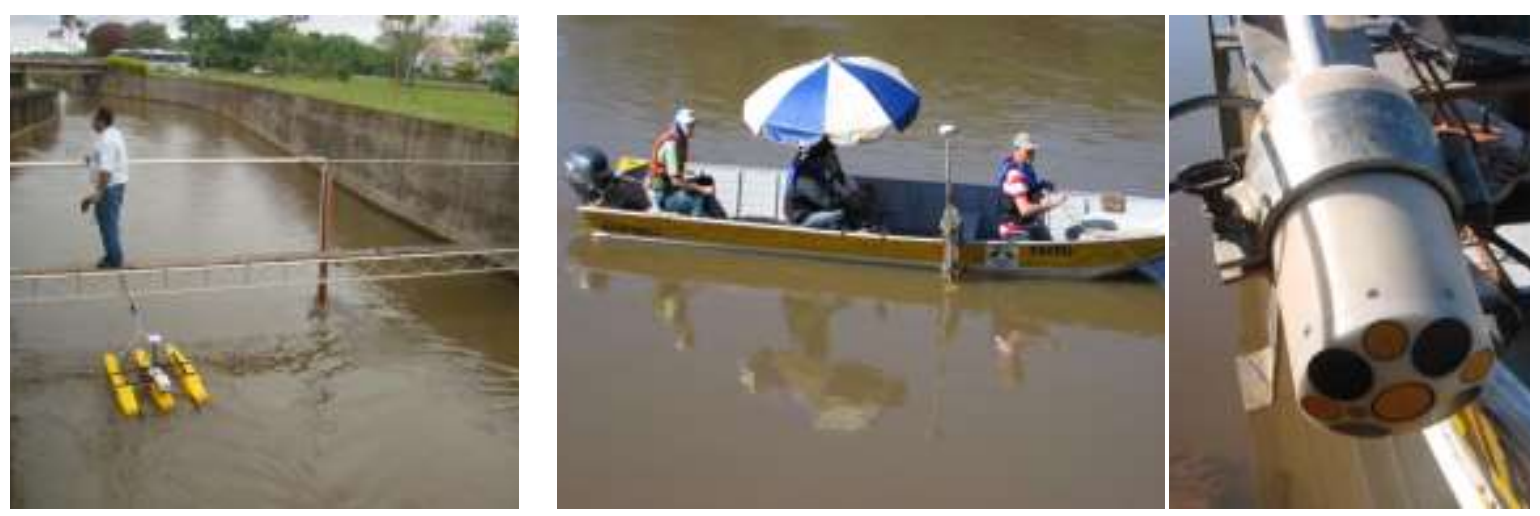

Figura 3.15 - Medição com ultrassônicos tipo Doppler em canais e rios de médio e grande porte, com embarcação (Acoustic Doppler Current Profiler - ADCP)

Os critérios de instalação desses medidores devem receber a mesma atenção descrita para os medidores de tempo de trânsito e eletromagnéticos, inclusive no que tange à necessidade de trechos retos de tubulação a montante e a jusante do sensor. Sua precisão pode variar de $1 \%$ a 5\%, dependendo das características do fluido, da velocidade do escoamento, diâmetro da tubulação e do fabricante (Lamon, 2006). Fluidos muito concentrados podem impedir a penetração das ondas ultrassônicas, impossibilitando a medição. 
Em consulta aos fabricantes Argonaut e Nivetec, o ultrassônico doppler instalado, com o dispositivo eletrônico secundário, custa US\$8.700 (R \$26.100 - 14/04/2015).

\subsubsection{Medidores de regime crítico}

Os medidores de regime crítico consistem num simples estrangulamento adequado da seção, no rebaixo ou no alteamento do fundo, ou ainda numa combinação dessas singularidades, capaz de ocasionar o regime livre de escoamento (Azevedo Netto et al., 2002).

A Calha Parshall, idealizada em 1918 por R.L. Parshall, engenheiro do Serviço de Irrigação do Departamento de Agricultura dos EUA, constitui-se de um canal de seção retangular com uma seção convergente, seguida de uma estrangulada e outra divergente. Essa calha não apresenta arestas vivas nem obstáculos consideráveis ao escoamento do fluido, sendo excelente para medições tanto de água bruta quanto esgotos e efluentes.

Frangipani (2007) alerta sobre o cuidado de especificar o medidor de acordo com a vazão a ser medida, sendo a referência de suas dimensões a largura na seção estrangulada, denominada pela letra "W" e instalar o medidor ultrassônico de nível (esse medidor secundário será abordado posteriormente) no local exato recomendado pelo fabricante. A determinação desse nível, representado pela letra "H”, fornece a vazão diretamente pela fórmula genérica para esses medidores determinada por: $\mathrm{Q}=\lambda . \mathrm{H}^{\mathrm{n}}$, sendo $\lambda$ e $\mathrm{n}$ constantes em função de $\mathrm{W}$.

Os fabricantes recomendam a instalação da calha em regiões sem turbulências na seção inicial, a fim de evitar prejuízo para os valores de medição. Os limites práticos dos medidores Parshall vão de W=1" e Qmín= 0,11 1/s até W=10’ e Qmáx = 5660 1/s. Há diversos fabricantes disponíveis no Brasil, sendo grande a diversidade de materiais empregados na sua construção. Especificamente, as calhas em Poliéster Reforçado com Fibra de Vidro (PRFV) vêm sendo bastante utilizadas, apresentando custos acessíveis, resistência química e mecânica, e facilidade na construção (vide Figura 3.15). As calhas Parshall têm precisão de medida em torno de $1 \%$ (Lamon, 2006).

As calhas Palmer-Bowlus funcionam de maneira muito semelhante às calhas Parshall. No entanto, apresentam seção semicircular, ideais para instalação direta em tubulações, sem necessidade de construção de canais retangulares (vide figura 3.16). Podem ser fornecidas com 
as extremidades flangeadas, com pontas de tubo para conexão com luva de correr ou lisa, conforme instalação no campo. São majoritariamente fabricadas em PRFV e dispõem de larga faixa de medições, determinadas pelo diâmetro " $\mathrm{D}$ ", desde $\mathrm{D}=4$ " e $\mathrm{Q}=3,28 \mathrm{l} / \mathrm{s}$ até $\mathrm{D}$ $=48$ " e $\mathrm{Q}=1769,51$ 1/s. Apresentam precisão de 3\% (Lamon, 2006), sendo recomendadas para escoamentos em superfície livre em tubulações circulares (tipo "meia-cana”). As recomendações quanto à escolha da dimensão, material e instalação da Calha Palmer-Bowlus seguem os mesmos princípios descritos para a Calha Parshall.
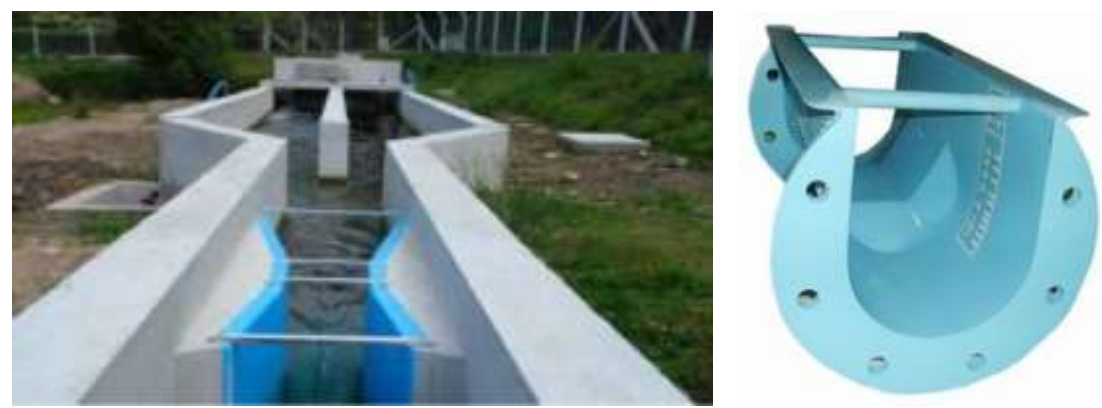

Figura 3.16 - Calha Parshall instalada (esq.) e calha Palmer-Bowlus (dir.) Cortesia: Inccer

O preço da calha Parshall varia de acordo com o tamanho do canal a ser instalado. Foi apreçado somente o valor da calha apropriada para um canal de 1 metro de largura, que instalada custa US\$3.300 (R\$9.900 - 14/04/2015).

Assim como as calhas supracitadas, os vertedouros são medidores de regime crítico capazes de medir a vazão por meio do conhecimento da altura da lâmina d'água no mesmo. Essa medição pode ser feita com um medidor ultrassônico de nível, relatado a seguir. Igualmente, basta entrar como a medida da altura da lâmina d'água, denominada "h", na fórmula do vertedouro e obtém-se a vazão escoada pela seção. Existem vários tipos de vertedouros, sendo mais comuns os retangulares, as triangulares e os trapezoidais.

É preferível a utilização de vertedouros que tenham sido bastante experimentados, com sua equação conhecida e consagrada (Frangipani, 2007). Deve-se atentar para que o escoamento seja livre, as bordas bem talhadas, na posição horizontal, sendo que toda a água deve escoar unicamente pelo vertedouro. A medida de h deve ser feita a montante do vertedor, de acordo com a recomendação técnica para o tipo escolhido. 
Vertedouros Trapezoidais: Segundo Porto (2006), existem diversas fórmulas para o cálculo da vazão em vertedouros retangulares de parede fina, sendo a mais usual a fórmula de Francis, onde $\mathrm{Q}=1,838 \times \mathrm{L} \times \mathrm{h}^{3 / 2}$, sendo $\mathrm{L}$ a largura do vertedouro e $\mathrm{h}$ a carga medida a montante do mesmo. Para o caso de vertedouros com contrações laterais, a fórmula deve ser corrigida de acordo com o número de contrações. Deve-se ter o cuidado para que seja permitido ao ar circular livremente sob a lâmina vertente, caso contrário a vazão medida será inferior a real devido à contração da veia líquida causada pelo arraste desse ar. Foi apreçado o valor de aquisição e instalação de um vertedouro retangular de soleira delgada para um canal com 1 metro de largura: US\$2200 (R \$6.600 - 14/04/2015).

Vertedouros Trapezoidais: Cipoletti determinou o vertedouro trapezoidal com inclinação de 1:4 em suas faces de forma a compensar o arraste de ar. Dessa maneira, calcula-se a vazão diretamente pela fórmula de Francis (Porto, 2006).

Vertedouros Triangulares: Porto (2006) recomenda a utilização de o vertedouro triangular com ângulo de $90^{\circ}$ entre suas faces. É excelente para vazões reduzidas e obtêm-se o cálculo da vazão por meio da fórmula de Thomson: $\mathrm{Q}=1,40 \times \mathrm{h}^{5 / 2}$.
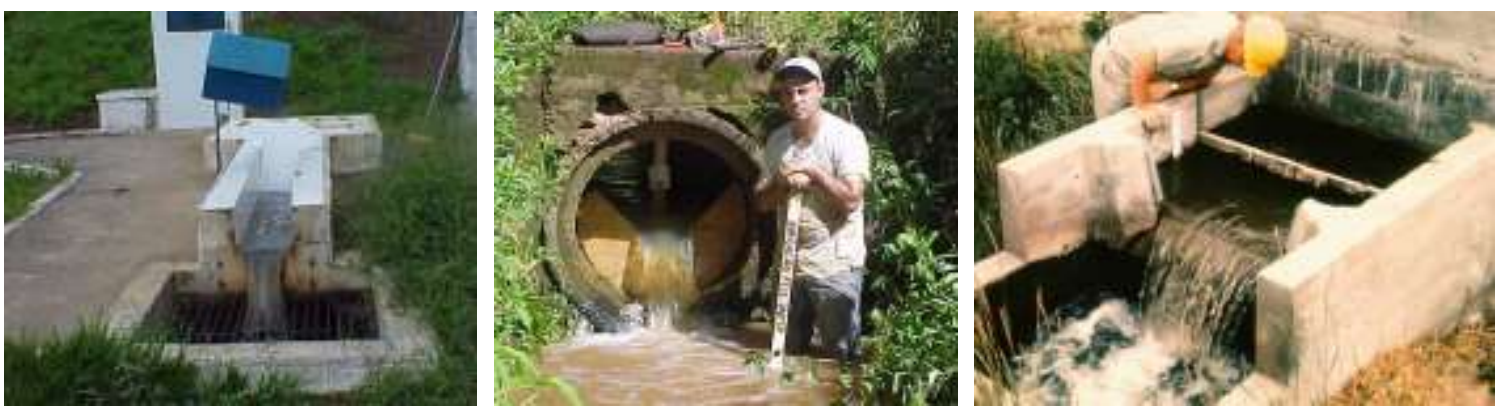

Figura 3.17 - Vertedouro retangular (esq.), triangular (centro) e trapezoidal (dir.)

Outros vertedouros: Podem ainda ser utilizados outros tipos tais como circulares, tubulares ou tipo Sutro, observando o conhecimento prévio das equações relativas a cada um, instalando-os e/ou construindo-os criteriosamente. É possível comprar vertedouros prontos de diversos fabricantes, principalmente em PRFV, desde que especificadas as vazões mínimas, médias e máximas de escoamento. Os vertedouros são alternativas mais simples e econômicas, se comparados às calhas Parshall e Palmer-Bowlus, cabendo selecionar aquele mais adequado a cada situação e instalar o medidor de nível na distância correta e recomendada. 


\subsubsection{Medidores de nível}

Os medidores de nível são equipamentos eletrônicos instalados em conjunto com as calhas Parshall e os vertedouros, sendo utilizados como auxiliares a esses medidores, e responsáveis pela leitura do nível d'água em intervalos de tempos pré-definidos, a fim de gerar uma totalização volumétrica do fluxo de água que passa pelos medidores de regime crítico. Podem ser classificados, basicamente, em dois tipos: os transdutores sob pressão e os sensores sem contato com a água.

Transdutores sob pressão: também denominados de sensores hidrostáticos, esses medidores de nível são compostos por uma membrana sensível e um sensor acoplados a um circuito eletrônico, encapsulados na extremidade de um cabo. Os transdutores determinam o nível através da medida da pressão da coluna de água, podendo o sensor estar diretamente submerso ou acoplado externamente (vide figura a seguir). A pressão é medida pela resistência elétrica gerada pelo sensor, em intervalos de tempo ajustáveis, por meio do circuito eletrônico, obtendo-se o nível d'água naquele momento. Em consulta aos fabricantes GE e Nivetec, o sensor de pressão custa, em média, US\$800 (R \$2.400 - 14/04/2015).
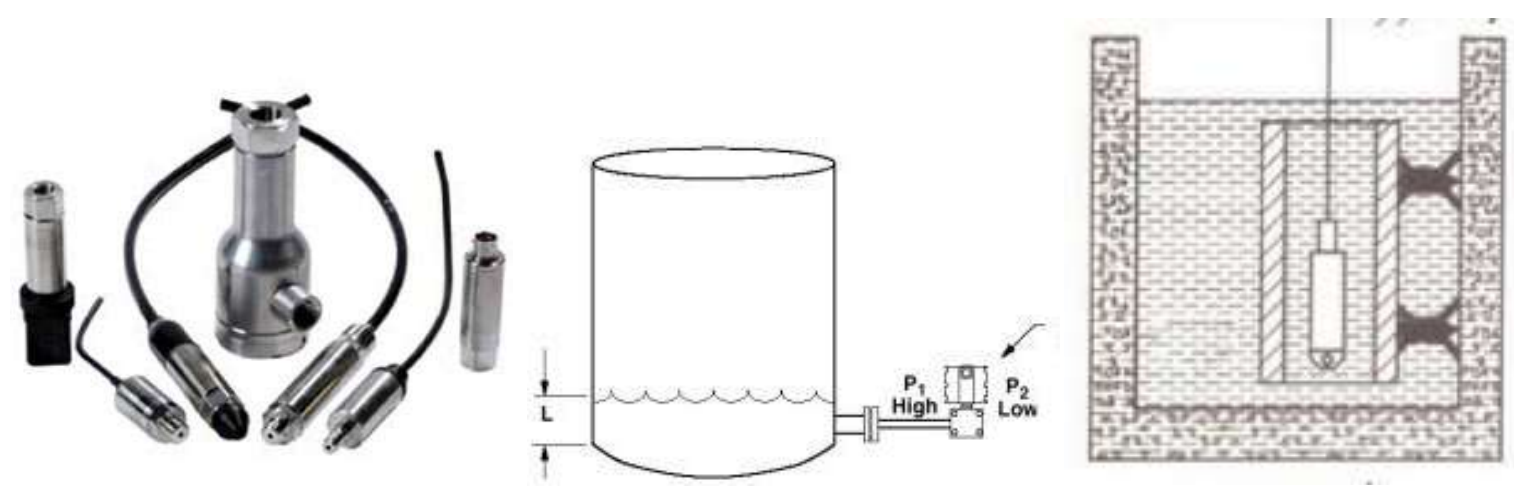

Figura 3.18 - Sensor de pressão hidrostático (esq.), acoplado externamente (centro) ou submerso (dir.) - Cortesia: GE

Sensores sem contato com a água: para leitura do nível d'água sem contato com o meio, o princípio mais utilizado comercialmente é o medidor ultrassônico. Esse equipamento, eletrônico micro processado, é capaz de registrar a distância entre sua face inferior e um material qualquer pela emissão e recepção de pulsos de ultrassom refletidos no material. Como vantagens desse medidor, tem-se:

- Não apresenta partes móveis nem contato algum com o fluido medido; 
- Custo relativamente baixo, se comparado aos outros equipamentos ultrassônicos. Foi orçado valor médio de US\$1.200 (R\$3.600) em consulta a três fabricantes;

- Alta precisão (em torno de 0,25\%, segundo informações dos fabricantes);

- Permitem montagem integral (sensor e transmissor) ou remota, conforme necessidade local;

- Versáteis em termos de faixa de medição (até $25 \mathrm{~m}$ para líquidos);

- Facilidade de conexão com um Data Logger através de sinal analógico ou de rede, diretamente do transmissor ao referido equipamento de armazenamento de dados.
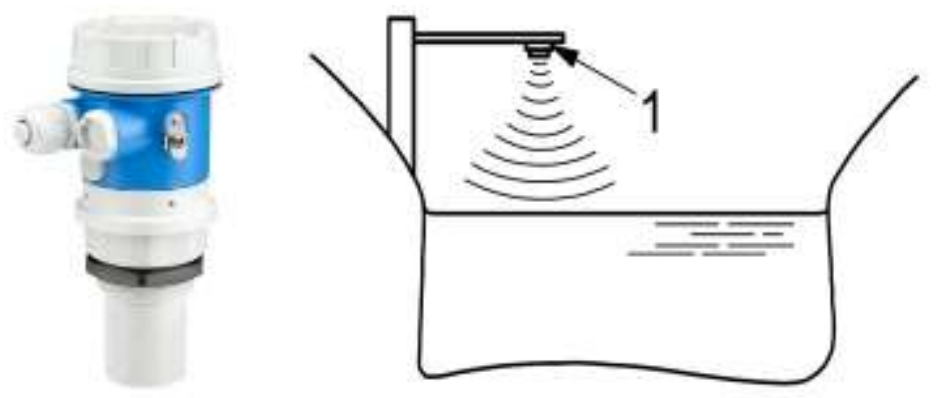

Figura 3.19 - Ultrassônico de nível: aparelho (esq.), trânsito pelo ar (dir.) Cortesia: Endress+Hauser

\subsubsection{Normatização dos equipamentos}

De uma maneira geral, todos os instrumentos aqui descritos, desde que adquiridos por meio de fabricantes ou representantes estabelecidos no Brasil e reconhecidos pelo mercado, seguem as normas da ISA - International Society of Automation.

No Brasil, as normas que regulamentam os instrumentos de medição de vazão, nível e pressão, assim como toda instrumentação industrial são as da ABNT, Associação Brasileira de Normas Técnicas, sempre prevalecendo a última edição. No caso de inexistência de norma ABNT, as que regularizam são as internacionais, ISA (Instrumentation, Systems and Automation Society), IEC (International Electrotechnical Commission), IEEE (Institute of Electrical and Electronics Engineers), NEMA (National Eletrictrical Manufactorers Association), e ASTM (American Society for Testing and Materials). Como referência, todas as normas de equipamento de medição são publicadas pela ISO (International Organization for Standardization). 
No Brasil, no que tange às medições de vazão, as normas elaboradas pela ABNT e em vigor são traduções publicadas. Seguem as normas em vigor relacionadas ao tema:

- $\quad$ ABNT NBR 10396:1988: Medidores de vazão de fluidos - Classificação;

- $\quad$ ABNT NBR 10977:1989: Medidor de vazão de fluidos - Terminologia;

- ABNT NBR ISO 4185:2009: Medição de vazão de líquidos em dutos fechados Método gravimétrico;

- ABNT NBR ISO 5167-1:2008: Medição de vazão de fluídos por dispositivos de pressão diferencial, inserido em condutos forçados de seção transversal circular. Parte 1: Princípios e requisitos gerais;

- ABNT NBR ISO 5167-1:2008: Medição de vazão de fluídos por dispositivos de pressão diferencial, inserido em condutos forçados de seção transversal circular. Parte 2: Placas de orifício;

- ABNT NBR ISO 6817:1999: Medição de vazão de líquido condutivo em condutos fechados - Método utilizando medidores de vazão eletromagnéticos;

- ABNT NBR ISO 9104:2000: Medição de vazão de fluidos em condutos fechados Métodos para avaliação de desempenho de medidores de vazão eletromagnéticos para líquidos;

- $\quad$ ABNT NBR ISO 9826:2008: Medição de vazão de líquido em canais abertos - Calhas Parshall e SANIIRI;

- ABNT NBR ISO3846:2011: Hidrometria - Medição de vazão em canal aberto utilizando vertedores retangulares de soleira espessa.

\subsection{SISTEMAS DE SUPORTE À DECISÃO}

A abordagem da necessidade de medição e da exigência quanto às vazões outorgadas, ou seja, da fiscalização do uso de recursos hídricos em si, envolve várias questões:

- Demanda pela água (vazão outorgada, se é captação ou lançamento, etc.);

- Oferta da água (localização do empreendimento, vazões de referência, etc.);

- Classificação do uso (comprometimentos individual e coletivo, nível de significância);

- Nível de exigência quanto à classificação: se há necessidade de instalar equipamento;

- Tipos de monitoramento a serem exigidos ou equipamentos a serem instalados. 
Observa-se, dessa forma, que propostas de soluções para abordagem do tema exigem grande complexidade, uma vez que o mesmo trata de inúmeras variáveis e incertezas. Sendo assim, torna-se necessário adotar uma abordagem sistêmica para encontrar soluções satisfatórias ao problema decisório.

Lanna (2002) conceitua a abordagem sistêmica à abstração, ou simplificação, de um problema complexo, de tal maneira que apenas sejam mantidas as informações mais relevantes para sua solução.

Dooge (1973 apud Tucci, 1998) conceitua sistema como qualquer estrutura, esquema, ou procedimento, real ou abstrato, que, em um dado tempo de referência, interrelaciona-se com uma entrada, causa ou estímulo de energia ou informação e uma saída, efeito ou resposta de energia ou informação.

Já o processo de tomada de decisão é a atividade de analisar alternativas e escolher uma delas. Porto et al. (2002) relatam que a teoria de decisão procura formalizar e tornar mais objetiva a escolha entre muitas alternativas em um ambiente de incertezas. Como tomar decisão é fazer uma escolha entre ações, é preciso primeiro identificar essas possíveis ações (variáveis de decisão) em uma lista de decisões exaustivas e mutuamente exclusivas (Lindley, 1998).

Scott Morton (1971 apud Loucks, 1995), no início da década de 1970, deu início aos chamados Sistemas de Suporte à Decisão - SSD, quando delineou os principais conceitos envolvidos num sistema denominado por ele próprio como Sistema de Decisões Gerenciais. Esse sistema compreendia estruturas computacionais interativas que tinham o objetivo de auxiliar os responsáveis pela tomada de decisões a utilizar dados e modelos para solucionar problemas não muito bem delineados.

Porto e Azevedo (2002) conceituam os sistemas de suporte a decisão como sistemas constituídos por bases de dados e modelos matemáticos que, interagindo entre si, propiciam, através de uma interface gráfica, o diálogo entre o tomador de decisões e o computador. A Figura 3.19 apresenta a estrutura típica de um sistema de suporte a decisão: 


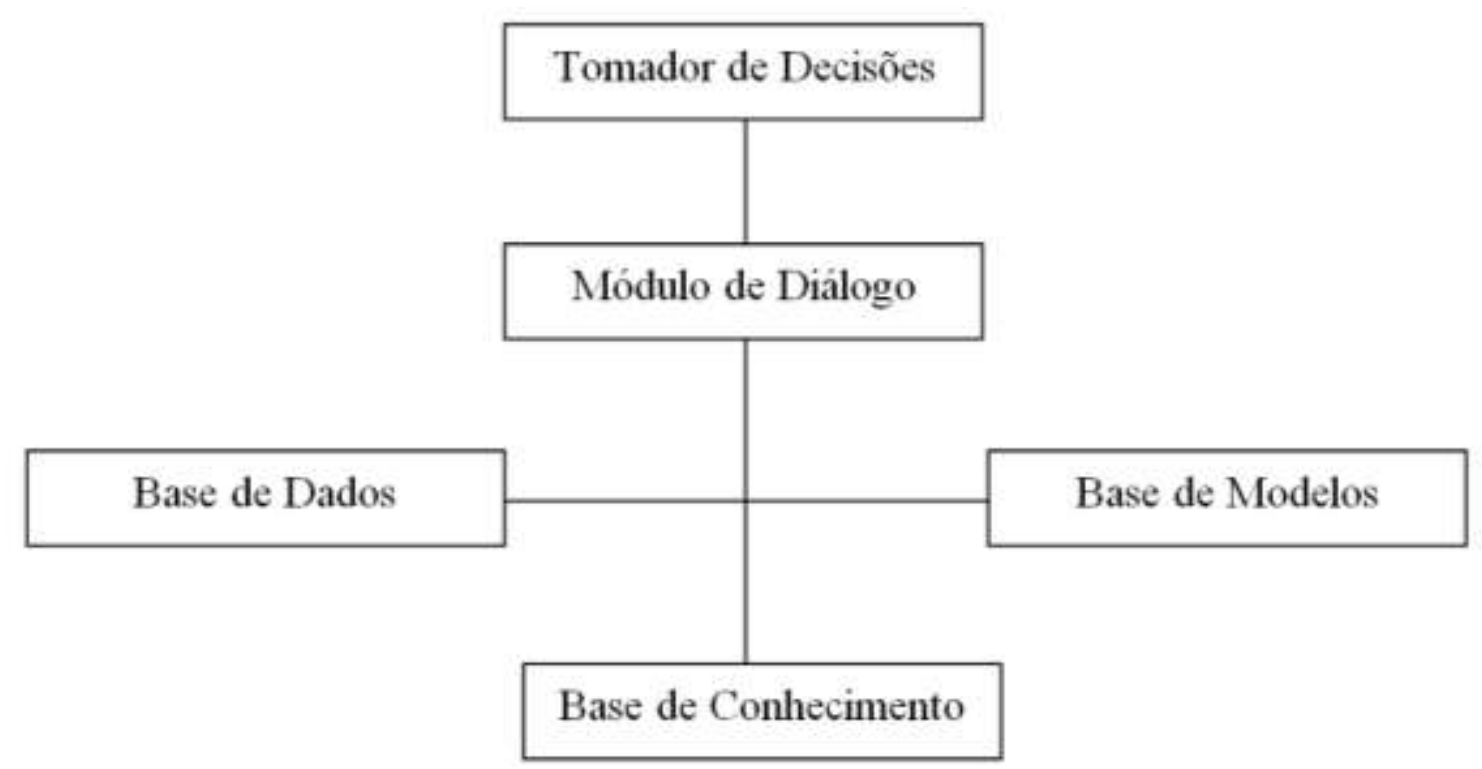

Figura 3.20 - Estrutura típica de um sistema de suporte a decisão (Porto e Azevedo, 2002)

De acordo com a figura acima, um SSD apresenta os seguintes componentes (Porto e Azevedo, 2002):

- Base de Dados: reúne e gerencia as informações do sistema;

- Base de Modelos: contém os modelos utilizados no sistema para atendimento a solução do problema;

- Base de Conhecimentos: conhecimentos que implicam na experiência de especialistas, permitindo geralmente a incorporação de informações que não são passíveis de tratamento pelos módulos anteriores;

- Módulo de Diálogo: responsável pela comunicação do usuário com o computador.

Um conceito importante abordado por Rodrigues (2005) é que a função principal de um SSD seja analisar os fatores envolvidos e oferecer subsídios que auxiliem a tomada de decisão. Complementando, Collischonn (2014) enfatiza que um SSD seja um sistema de apoio, e não de tomada de decisão. Assim, as saídas do sistema devem ser na forma de gráficos, mapas, tabelas ou indicadores de fácil interpretação, e possuir flexibilidade suficiente para não engessar a tomada de decisão.

Cruz (2004) ressalta que um SSD deve possuir um conjunto de recursos em diálogo, dados e construção de modelos, equilibrado e facilmente utilizável por usuários não técnicos. Sendo assim, seu desenvolvimento parte do pressuposto de uma interface autoexplicativa, 
priorizando a interatividade entre o sistema e o operador, bem como possibilitando a adaptabilidade e flexibilidade às alterações no ambiente.

Segundo Alter (1980), as principais características de um SSD são a interatividade entre o usuário e a máquina, a acessibilidade - devem ser de fácil uso - e a flexibilidade, a fim de poder se adaptar às necessidades das diversas situações.

Como características principais, Cruz (2004) elenca os seguintes aspectos de um SSD:

- Utilizam modelos ou técnicas analíticas, combinados com funções tradicionais, a fim de acessar e recuperar as informações;

- Concentram-se de forma mais específica em recursos que facilitem seu uso para pessoal não especializado em computação, com ênfase interativa e amigável;

- Possibilitam a adaptação a mudanças no ambiente e na abordagem à tomada de decisões utilizada pelo usuário.

No que tange aos SSD's no âmbito do planejamento e gerenciamento de recursos hídricos, tendo em vista as diversas variáveis envolvidas, pode-se utilizar as ferramentas desses sistemas de apoio para estruturar os complexos problemas existentes, de modo a propiciar tomadas de decisões mais rápidas e precisas (Cruz, 2001).

Almeida (2006) relata que um SSD na área de recursos hídricos é composto, em geral, por três componentes: um banco de dados, um conjunto de modelos e interfaces de acesso. Relata que, por meio dessas interfaces, o usuário realiza simulações na busca de um gerenciamento e planejamento racional dos recursos hídricos. Exemplificando, simulações hidrológicas que tratem da água em qualidade e quantidade, podem ser realizadas com os SSD's para diversos fins, como alocação de água ou disponibilidade para outorga. Daí a necessidade de um conjunto de modelos, módulos de diálogos e informações armazenadas em bancos de dados. 


\subsubsection{Sistemas de suporte à decisão específicos para a outorga}

Verifica-se que, no Brasil, existem diversos trabalhos na área de recursos hídricos que propõem sistemas de suporte à decisão para análise de outorgas. A seguir, será elencada, em ordem cronológica, uma família de SSD's que trata de temas como disponibilidade e alocação de água, significância dos usos consuntivos em uma determinada região, com vistas a auxiliar os processos decisórios relativos à outorga de direito do uso de recursos hídricos. As ferramentas e modelos contidos nesses sistemas constituem uma base para montagem do SSD desenvolvido na presente dissertação.

Ferraz e Braga (1998) desenvolveram um SSD para outorga, em caráter experimental, para a bacia do rio Corumbataí (SP). Um aspecto interessante é que esse sistema contempla, além do aspecto quantitativo, o aspecto qualitativo da outorga para diluição de efluentes.

Silveira et al. (1998) apresentam um SSD bastante abrangente para outorga na bacia hidrográfica do rio Santa Maria (RS), levantando em conta um subsistema de cadastro de usuários na bacia (disponibilidade hídrica).

Pereira, P. R. G. (2000) desenvolveu um SSD para análise dos pleitos de outorga denominado DAFNE, com aplicação para o caso da bacia do Lago Descoberto (DF/GO). O trabalho foi concebido em três módulos: o $1^{\circ}$ caracteriza sistema de forma geral, indicando os critérios de alocação de água; o $2^{\circ}$ corresponde ao balanço hídrico, ou seja, verifica as disponibilidades do recurso água versus as demandas pelo seu uso; e o $3^{\circ}$ faz um controle das outorgas por meio de registro das informações relevantes do sistema e dos usuários, renovando-as a cada solicitação ou renovação de outorga.

Santana et. al (2002) elaboraram um SSD utilizando como ferramenta a planilha MS Excel®, tendo como estudo base a bacia do rio das Fêmeas (BA). Nesse sistema, o balanço hídrico é feito por afluentes, e cada um destes afluentes corresponde a uma nova aba na planilha, o que torna a caracteriza uma topologia hídrica relativamente simples.

Matos (2004) aprimorou o SSD desenvolvido por Pereira (2000), tendo formulado o sistema DAFNE 0.97/2003, incorporando na análise de pleitos de outorga, levando-se em conside- 
ração os aspectos de qualidade da água. O trabalho incluiu novos testes numa bacia hidrográfica de características socioeconômicas e hidrológicas diferentes, a bacia do rio Jacuípe, localizada no estado da Bahia.

Rodrigues (2005) concebeu o sistema denominado SSD-RB, constituído pelo modelo de outorga e cobrança pelo uso da água RM1, elaborado pela própria Rodrigues (2000), e pelo modelo de qualidade das águas QUAL2E. A ferramenta foi aplicada à bacia do rio Jundiaí, afluente do rio Tietê, localizado no Estado de São Paulo.

Porto et al. (2005) criaram o sistema Acquanet, originado do MODSIM (Roberto, 2002). O Acquanet representa o sistema de recursos hídricos por meio de nós (reservatórios, demandas e confluências) e arcos (trechos de rios, canais e adutoras), tendo sido aplicado principalmente para sistemas de reservatórios.

Brigagão (2006) desenvolveu um aplicativo a ser incorporado ao Acquanet, capaz de auxiliar, sob o ponto de vista econômico ou financeiro, um processo de tomada de decisão relacionado à cobrança, à outorga ou ao enquadramento. $\mathrm{O}$ estudo de caso escolhido para este aplicativo foi a bacia da barragem do Descoberto no Distrito Federal.

Marques (2006) criou um SSD denominado Aquora, que diferencia pelo fato da operação do sistema ser possibilitada via internet, em modo multiusuário. O sistema é integrado em rede, e baseia-se na estruturação de um acervo das informações necessárias à gestão de outorgas, em um banco de dados simples e online, aplicado à bacia do rio Doce.

Ravanello (2007) elaborou uma adaptação do Acquanet, denominada OutorgaLS, voltada para outorga de uso da água, tendo sido incorporadas facilidades de uso em relação ao Acquanet. Para verificação do funcionamento dessa aplicação, tomou a bacia hidrográfica do rio Ibicuí-RS para estudo.

Lima (2007) criou um sistema de apoio mais abrangente, denominado Riverhelp!, utilizado como ferramenta para auxiliar no planejamento e gerenciamento integrado de bacias hidrográficas. Esse SSD inclui ferramentas de análise que permitem considerar fatores ambientais, econômicos e sociais, além das funções para auxiliar os processos de outorga. Ele é composto por quatro módulos principais, com código aberto baseado na tecnologia OpenMI, 
o que permite aos usuários alterar e incluir funções. Foi aplicado como estudo e análise para as Bacias Hidrográficas dos Rios Piracicaba, Capivari e Jundiaí.

Collischonn\&Lopes (2009) criaram um sistema de suporte à decisão para análise de outorgas na bacia do rio Paraná. Denominado Sistema de Controle de Balanço Hídrico (SCBH), esse sistema foi desenvolvido em Matlab 2006 e é capaz de realizar análises do impacto de captações de água e de lançamentos de efluentes na disponibilidade hídrica existente, bem como de identificar trechos de rios críticos.

Pereira (2010) desenvolveu um sistema de suporte à decisão para outorga de captação de água, tomando como estudo de caso a bacia do rio dos Sinos-RS. Uma característica interessante desse SSD é a integração do mesmo com um sistema de informação geográfica (SIG), tornando mais visual o comprometimento hídrico e mais didática a tomada de decisão.

Finalizando, Collischonn (2014) aprimorou o Sistema de Controle de Balanço Hídrico SCBH criado em 2009, que foi desenvolvido inicialmente em linguagem Matlab e consistia de um sistema local. O novo sistema funciona em computadores individuais ou em grupos de computadores conectados a um mesmo servidor institucional, em linguagem PHP com banco de dados SQL Server. Este SSD vem sendo utilizado na prática para análise de outorgas na Agência Nacional de Águas e em alguns órgãos gestores estaduais e será detalhado a seguir.

\subsubsection{O Sistema de Controle de Balanço Hídrico - SCBH}

O SCBH permite analisar a interferência conjunta de outorgas para captações e lançamentos em bacias com vários domínios e, consequentemente, com participação de vários tomadores de decisão, permitindo uma efetiva integração do gerenciamento de recursos hídricos (Collischonn, 2014).

Um dos propósitos desse sistema foi compatibilizar o domínio (administração) dos recursos hídricos, entre os Estados e a União. Isso porque a lei das águas preveja entre seus fundamentos que a unidade de gestão dos recursos hídricos seja a bacia hidrográfica, a Constituição Federal dividiu em cursos d'água, e não em bacias hidrográficas, a administração do uso da água. 
O produto a ser fornecido pelo SCBH são os indicadores de comprometimento, onde o ICI é o indicador de comprometimento individual, ICC é o indicador de comprometimento coletivo, descritos nos itens 3.2.5 e 3.2.6 anteriores.

Collischonn (2014) descreve que, com base na interpretação dos indicadores, o tomador de decisão dá o encaminhamento adequado ao pedido de outorga. Por exemplo, em alguns órgãos gestores, os comprometimentos individual e coletivo não podem superar, digamos, $20 \%$ e $80 \%$ da vazão de referência. É também por meio do indicador que o tomador de decisão avalia o cumprimento a eventuais normativos referentes a vazões mínimas a serem mantidas no rio.

Para cálculo dos indicadores ICI e ICC, o SCBH extrapola a vazão de referência do ponto onde esta é conhecida (a estação de monitoramento) para o local onde se deseja estima-la (o novo ponto de captação). Isto pode ser feito por meio de uma relação de áreas de drenagem ou uma regionalização de vazões.

Continuando, o balanço hídrico entre demandas e disponibilidade hídrica no SCBH é feito por trechos de rio. Um trecho é a feição da hidrografia situada entre duas confluências. A discretização do sistema por trechos implica que, a cada trecho, corresponde uma única vazão de referência. Dentro de um mesmo trecho, não é possível distinguir qual usuário está a montante e a jusante. Tudo se passa como se todos usuários estivessem no exutório do trecho. Para uma base hidrográfica suficientemente densa, esta discretização não causa maiores problemas.

Da mesma forma, a apresentação dos resultados de indicadores de comprometimento corresponderá ao trecho onde o usuário se encontra, não sendo possível calcular comprometimentos coletivos distintos para usuários em um mesmo trecho.

As informações de cada trecho são armazenadas no SCBH segundo uma metodologia para classificação de cursos d'água conhecida como ottocodificação, desenvolvida pelo engenheiro Otto Pfaffstetter, do extinto DNOS. Ela classificação consiste na atribuição de algarismos inteiros a cada sub-bacia, sendo que os algarismos pares são atribuídos às quatro maiores sub-bacias (em área de drenagem), em ordem crescente de jusante para montante. 
Já os algarismos ímpares são atribuídos às chamadas interbacias, ou bacias incrementais, situadas entre as sub-bacias principais (ANA, 2006 apud Collischonn, 2014). A Figura a seguir mostra um exemplo de codificação de sub-bacias:

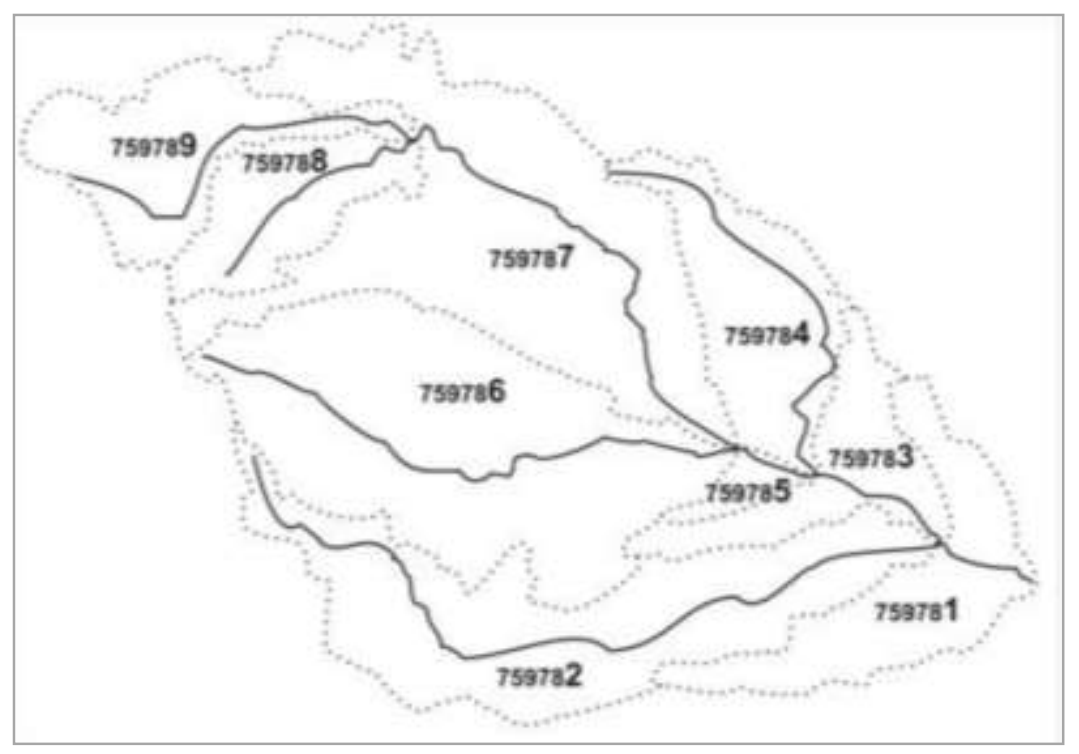

Figura 3.21 - Codificação otto - Cortesia ANA (2006)

A versão local do SCBH, desenvolvida em MATLAB, foi aplicada às bacias do São Francisco, Paraná (exceto bacia do São Marcos), Piranhas-Açu, Paraíba do Sul, Tocantins e Doce. Já a versão Web do SCBH está disponível para a bacia do rio Uruguai, em conjunto com a bacia da Lagoa Mirim, bacia do rio São Marcos (DF/GO/MG), bacia do rio Preto (DF/GO/MG), bacia do Itapecuru (MA), além de um sistema dedicado aos reservatórios de domínio da União no semiárido nordestino (Collischonn, 2014). O endereço para acesso do SCBH na versão Web é http://scbh.ana.gov.br. A Figura a seguir mostra as bacias em que o sistema foi implementado. 


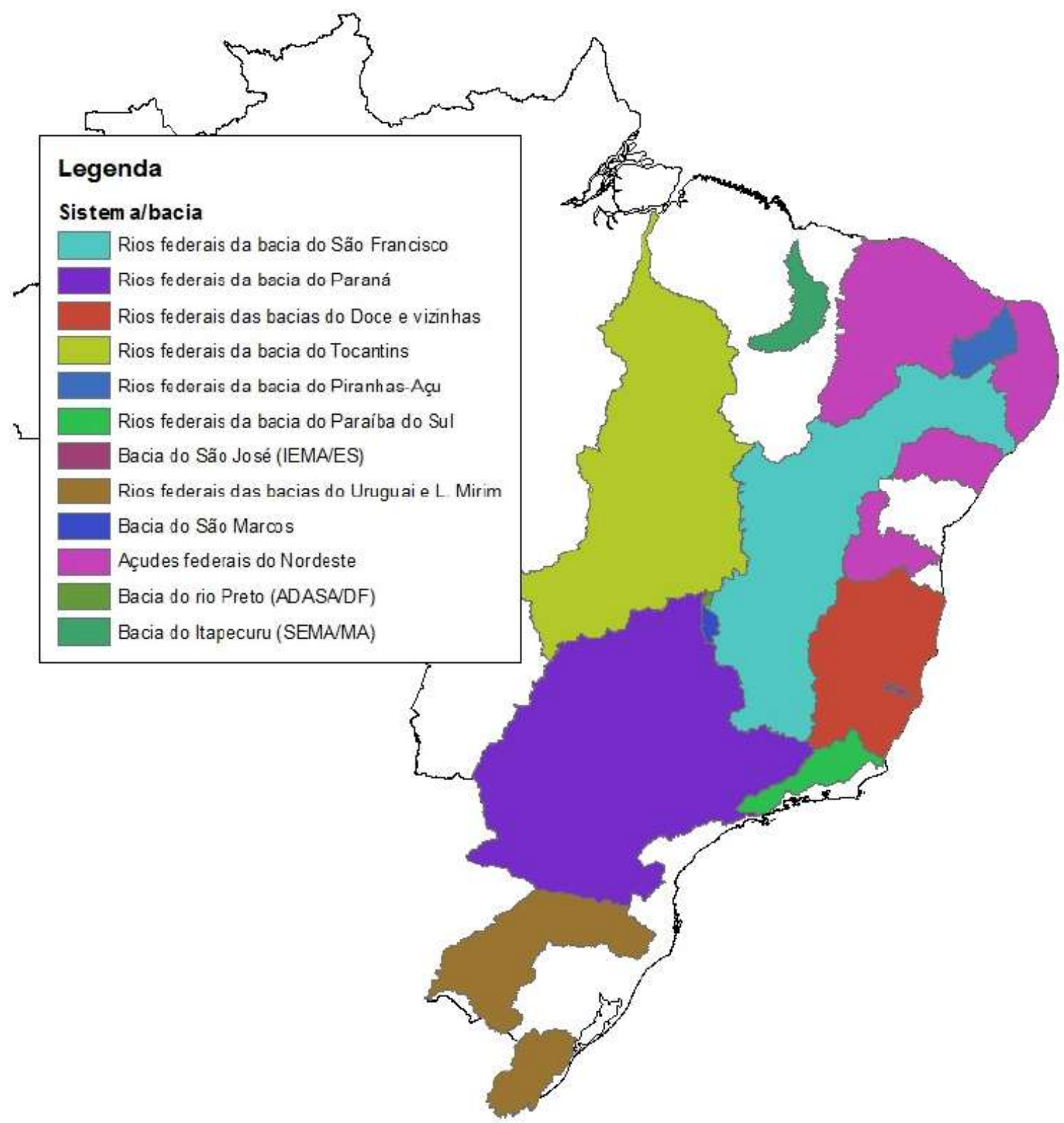

Figura 3.22 - Bacias em que o SCBH foi implementado (Collischonn, 2014)

A versão inicial do SCBH, em linguagem MATLAB, já está sendo adotada pela ANA e por alguns órgãos gestores estaduais para análise de outorgas, nas bacias supracitadas. A inovação desse SSD se dá na versão $W e b$, no que diz respeito ao tipo de usuário que pode acessar o sistema e obter resposta quanto ao uso de recursos hídricos a ser outorgado.

Explicitando melhor, na tela inicial, o sistema pergunta se o acesso está sendo realizado por usuário interno ou externo. Por usuário interno entende-se um analista de algum órgão gestor que use o SCBH e que possua permissões de acesso para tal, inserindo login e senha. Este usuário irá inserir os dados de um requerimento de outorga, e o sistema irá fornecer informações para a tomada de decisão no que tange a conceder (ou não) a autorização do uso de 
recursos hídricos. A partir dos dados de resposta do sistema, o usuário poderá emitir um parecer favorável (ou não) à outorga de direito de uso solicitada.

Já o usuário externo é o público em geral, notadamente potenciais usuários de água ou profissionais da área. O público externo pode consultar se há disponibilidade hídrica no trecho para que o ponto solicitado possa ser outorgado. Ou seja, o usuário externo pode utilizar o sistema para verificação no que tange à possibilidade de seu requerimento de outorga ser aceito. Essa verificação preliminar sobre a disponibilidade hídrica de um dado manancial serve como planejamento ao usuário de recursos hídricos no que tange à solicitação do seu pedido de outorga.

Collischonn (2014) enfatiza a importância ao acesso de usuários externos, potenciais usuários de água, no que tange a conferir transparência ao gerenciamento de recursos hídricos, uma vez que permite ao usuário se familiarizar com os critérios para tomada de decisão, além de antecipar e evitar conflitos futuros. Além disto, esta versão externa também evita uma sobrecarga aos próprios analistas, que frequentemente têm que responder a este tipo de consulta informal.

Demonstra-se, a seguir, a versão Web do SCBH. Após a informação inicial sobre o usuário, podendo ser interno (com login e senha) ou externo, abre-se uma janela para selecionar qual das bacias se deseja fazer a análise de disponibilidade hídrica (vide Figura abaixo):

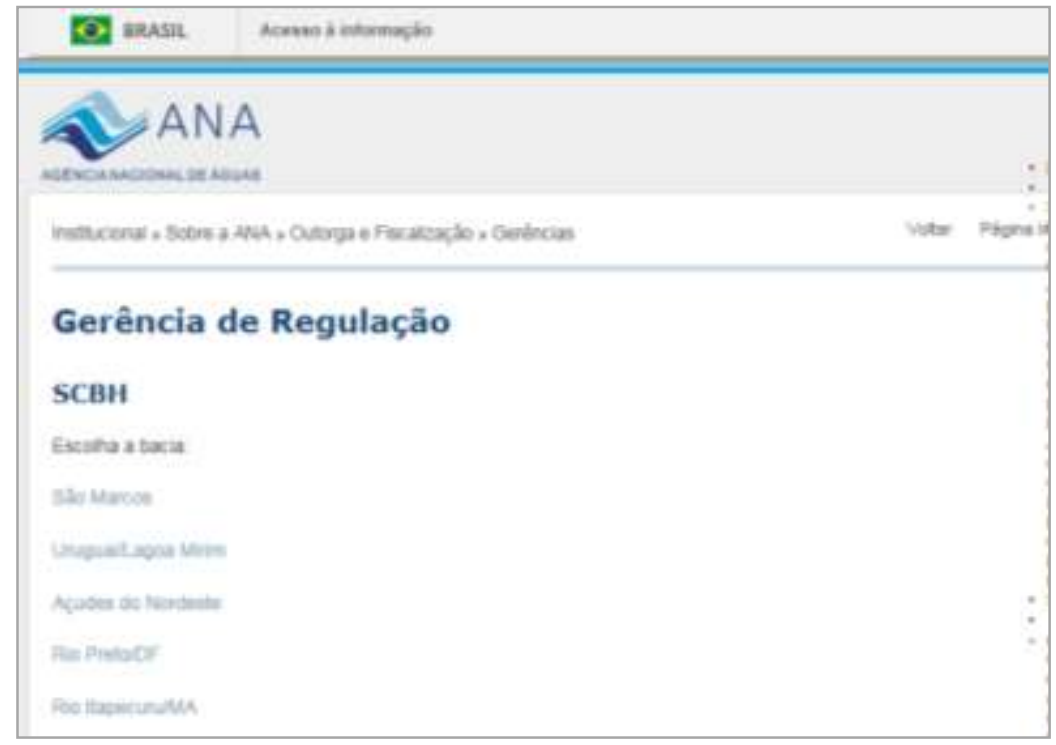

Figura 3.23 - Acesso ao SCBH via Web pelo endereço: http://scbh.ana.gov.br. 
Supondo que tenha sido escolhida a bacia do rio Uruguai, o sistema solicita as seguintes informações para entrada de dados: nome do usuário, número do processo, tipo de interferência (captação ou lançamento), vazão máxima e regime de operação ( $n^{\circ}$ de horas/dia e $n^{\circ}$ de dias/mês), e as coordenadas da interferência (latitude e longitude). Como exemplo, tomou-se uma coordenada conhecida no próprio rio Uruguai e considerou-se uma vazão de $500 \mathrm{~m}^{3} / \mathrm{h}$, sendo captação de água, conforme figura a seguir:

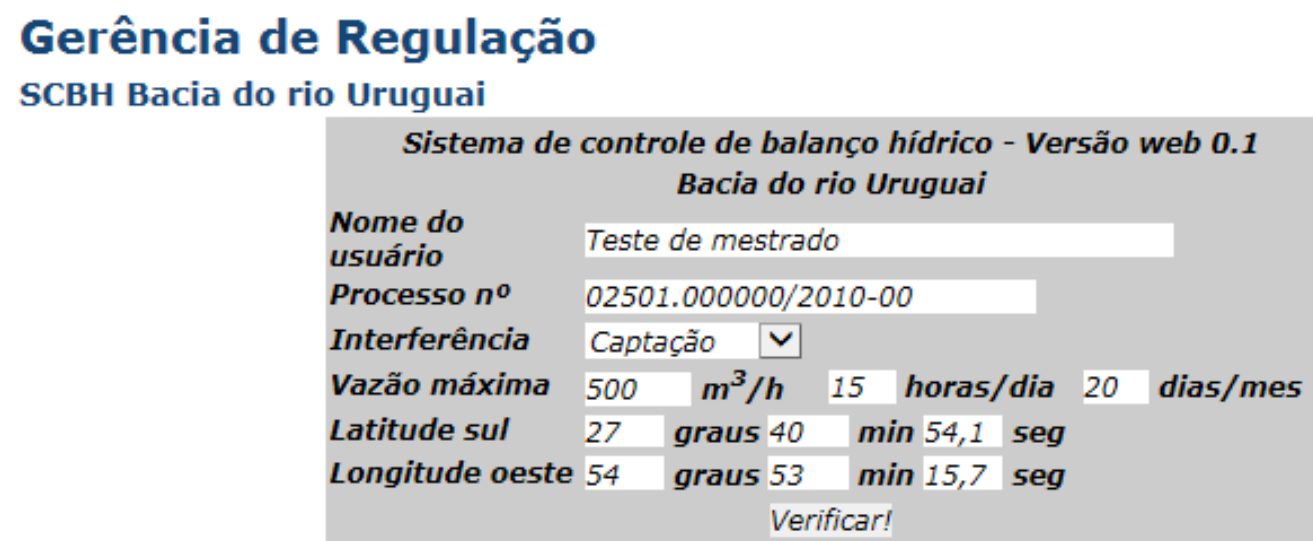

Figura 3.24 - Dados de entrada no SCBH via Web

O SCBH verifica as coordenadas geográficas pela ottocodificação e, consultando os códigos nos respectivos bancos de dados, o sistema obtém o município em que se localiza, bem como o nome do manancial e o domínio das águas (se estadual ou federal), conforme figura a seguir.



Figura 3.25 - Tela de identificação do manancial e município, detalhamento da demanda e regime a ser considerado, $\mathrm{SCBH}$ via $\mathrm{Web}$ 
Além da verificação da localização, o SCBH apresenta uma tabela com os valores de vazão máxima em todos os meses, podendo estes valores serem alterados. No fim da janela, solicita qual regime a ser considerado para cálculo da disponibilidade hídrica: vazão máxima instantânea, média diária, média mensal ou média anual (vide Figura anterior).

Outra tela aparece se o tipo de interferência for de lançamento, de acordo com Figura a seguir. Além da vazão máxima, as informações solicitadas em interferências de lançamento são os parâmetros de qualidade da água do efluente: Temperatura $\left({ }^{\circ} \mathrm{C}\right), \mathrm{DBO}(\mathrm{mg} / \mathrm{l})$, Nitrogênio Total (mg/l) e Fósforo Total (mg/l).



Figura 3.26 - Tela com identificação do rio e município e detalhamento dos dados do lançamento de efluentes, SCBH via Web

Finalizando, o SCBH realiza o balanço hídrico com as demais demandas da bacia e o cálculo dos Indicadores de Comprometimento Individual (ICI) e Coletivo (ICC). Em função dos indicadores, o sistema já emite um parecer prévio, indicando que o pedido de outorga pode ou não ser atendido. 


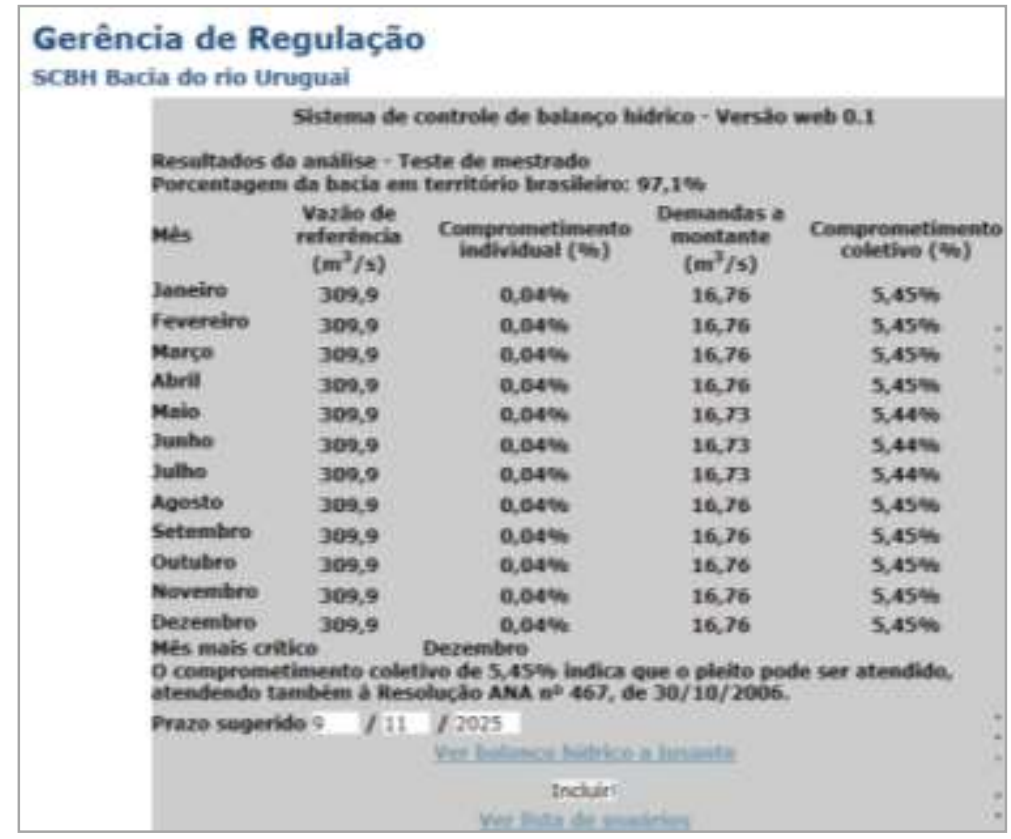

Figura 3.27 - Tela com os resultados da análise em termos quantitativos, SCBH via Web

Se o ponto de interferência for de lançamento, serão apresentadas as vazões de diluição segundo os parâmetros de qualidade, a vazão indisponível no trecho, bem como o cálculo dos Indicadores de Comprometimento Individual (ICI) e Coletivo (ICC).

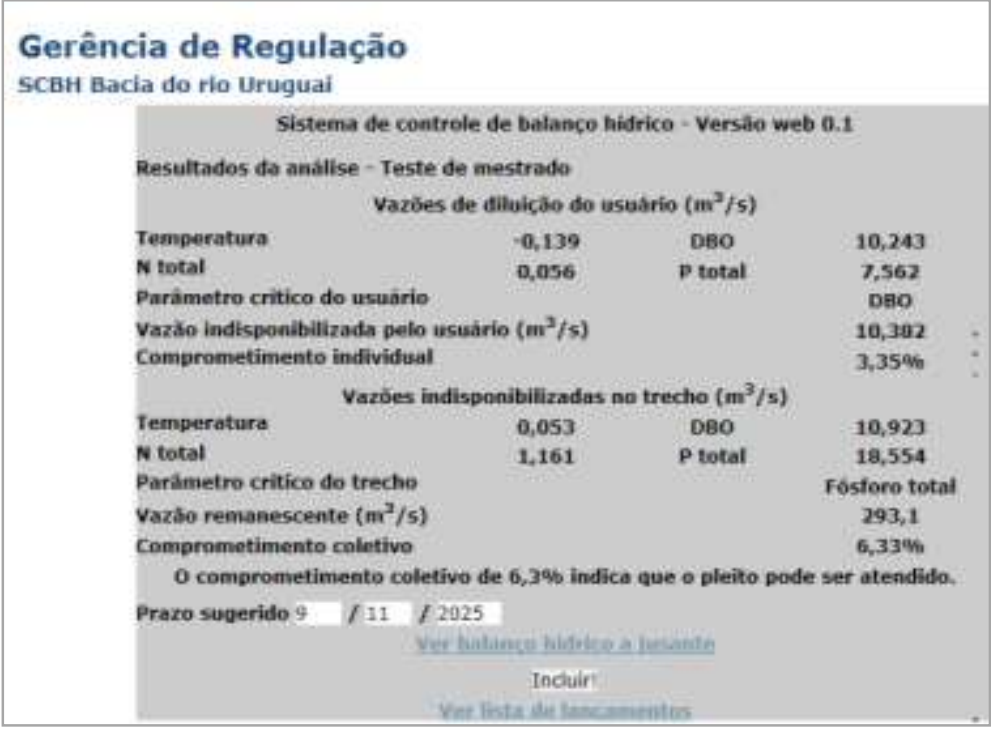

Figura 3.28 - Tela com os resultados da análise em termos qualitativos, SCBH via Web

Se estiver de acordo com a análise, o usuário interno, representado pelo órgão gestor, pode clicar em “incluir”. Para o público externo, representado pelo potencial usuário de recursos hídricos, o botão "incluir" não está habilitado. Com isso, sendo o analista do órgão gestor a utilizar, o novo usuário já será incluído no banco de usuários, e futuras análises o levarão em conta. 


\section{METODOLOGIA}

A metodologia desenvolvida procura estabelecer um nível de importância para vazões outorgadas numa determinada bacia e, a partir daí, definir um tipo de monitoramento com níveis de exigência diferenciados para que se tenha um controle dos referidos usos outorgados, inclusive recomendando quais equipamentos de medição de vazão são mais adequados para instalação.

Para tanto, a metodologia ora apresentada para desenvolvimento deste trabalho envolveu a consecução de quatro etapas principais:

(i) Definição de quais equipamentos de medição de vazão são mais adequados para instalação, dependendo do tipo de uso, sendo tubulação fechada (condutos forçados) ou superfície livre (canais abertos);

(ii) Sistematização de procedimentos para que se possa estabelecer um nível de importância para as vazões outorgadas, classificando-as em diferentes níveis de monitoramento em uma determinada bacia;

(iii) Verificação dos procedimentos com dados reais de vazões outorgadas na bacia do rio São Francisco, como estudo de caso; e

(iv) Elaboração de um fluxograma com os resultados do estudo de caso, de forma a possibilitar a construção de um sistema de suporte à decisão para controle de vazões outorgadas.

Apresenta-se, a seguir, a descrição de cada um desses processos:

\subsection{EQUIPAMENTOS DE MEDIÇÃO DE VAZÃO}

Para o controle e monitoramento das vazões outorgadas, é importante o conhecimento dos processos de medição de vazões em superfícies livres e condutos forçados. Dessa forma, realizou-se trabalho experimental na bacia hidrográfica do ribeirão Pipiripau (DF/GO), verificando o funcionamento de equipamentos de medição de vazão instalados em usuários outorgados na bacia. 
Foram construídas 5 estações hidrométricas (de medição de vazão) de uso de recursos hídricos, 4 em tubulações sob pressão e 1 em canal aberto, contemplando a instalação, automação, operação, manutenção, análise comparativa e a verificação da eficiência de diversos equipamentos de medição de vazão e volume de água bruta.

Complementando a parte experimental, considerou-se os estudos teóricos e o referencial bibliográfico constante do item 3.3 - "Sobre os equipamentos de medição".

Dessa forma, possibilitou-se a verificação de funcionamento, preço, desempenho, operação, manutenção, vantagens, desvantagens e recomendações gerais de cada um dos equipamentos de medição de vazão estudados na revisão teórica e bibliográfica e pesquisados na parte experimental do projeto.

Essa caracterização dos equipamentos é dinâmica e depende de constante atualização em função dos medidores disponíveis no mercado. O estudo dá subsídios à escolha dos equipamentos em função das exigências determinadas pela classificação das vazões outorgadas, conforme item 4.2 a seguir.

\subsection{CLASSIFICAÇÃO DAS VAZÕES OUTORGADAS}

Para que se possa estabelecer um nível de importância para as vazões outorgadas, foi elaborada uma sistematização de procedimentos, levando-se em conta inicialmente a questão da localização dessas vazões outorgadas, e em consequência disso, as condições de oferta, ou seja, de disponibilidade hídrica ligada à região dessas vazões.

Para tanto, dividiu-se os corpos d'água de uma bacia ou sub-bacia em trechos, podendo cada trecho ser um rio, ou um afluente de rio, ou um reservatório, levando em conta que a disponibilidade hídrica num determinado trecho influencia outro trecho subsequente. A referida disponibilidade, para cada trecho, foi representada por uma determinada vazão de referência Qreferencia (i), vazão esta considerada como limite superior de utilização da água em um determinado curso d'água. 
Verificaram-se então as condições de demanda, representadas pelas vazões outorgadas, sendo considerados aspectos quantitativos, levando em conta as vazões de captação, e qualitativos, tendo como principal parâmetro a $\mathrm{DBO}_{5,20}$, para cálculo da carga orgânica e das vazões de diluição.

Para cada uma das vazões outorgadas, foi relacionado um comprometimento individual, conforme visto no item 3.2.9, sendo este uma relação entre a vazão outorgada ao ponto de interferência com a vazão de referência no trecho de rio. Representa, neste caso, a significância individualizada da vazão outorgada na disponibilidade hídrica do trecho.

Já o comprometimento coletivo, tal qual visto no item 3.2.10, representa o quanto o corpo hídrico está efetivamente comprometido com todos os usos consuntivos em um determinado trecho. Para esse segundo aspecto, tomou-se a influência de todas as vazões outorgadas no trecho i, bem como as demais vazões outorgadas nos trechos anteriores. Sendo assim, em bacias onde já exista um comprometimento coletivo, ou seja, onde a situação da bacia se encontra em situação de pouca disponibilidade hídrica ou situações de conflito, verificou-se a necessidade de um maior controle dos usos outorgados para averiguação do real uso da água na bacia.

Partindo então do comprometimento individual de cada uma das vazões outorgadas num determinado trecho, e do comprometimento coletivo como um todo, tratou-se em seguida de definir um de controle dos usos outorgados por meio de exigências para estabelecimento de um monitoramento do seu uso, de forma gradativa, a depender da significância que a vazão outorgada demanda para cada trecho. Assim, quanto mais significante for a vazão outorgada no trecho, maior a exigência para controle do uso, tendo sido classificadas em níveis de exigência distintos, com maior rigor quanto ao tipo de monitoramento.

Levando em conta os conceitos de verificação do comprometimento individual de cada vazão outorgada no trecho, do comprometimento coletivo instaurado nesse trecho, e partindo da necessidade de estabelecer níveis distintos de exigência para cada vazão outorgada, de acordo com o referido comprometimento, foram criados índices relativos, estabelecendo uma razão entre cada uma das vazões outorgadas em determinado trecho i com a vazão de referência, tanto de forma individual, quanto de forma coletiva. Tais índices individuais e 
coletivos serviram para estabelecer uma classificação final de cada vazão outorgada num determinado trecho i, em relação a um nível de exigência para monitoramento dessa vazão.

Além dos índices relativos, foram também estabelecidos índices absolutos, de forma a possibilitar uma classificação quanto ao nível de controle e monitoramento de cada vazão outorgada pelo seu valor em si, independente do trecho onde está localizada.

Entretanto, os índices absolutos e relativos foram criados somente para classificar as vazões outorgadas, havendo então necessidade de estabelecer valores numéricos para os mesmos. Dessa forma, definiram-se indicadores gerais baseados no percentual de volume outorga e de número de vazões outorgadas por trecho, para verificar a distribuição das vazões outorgadas, em termos de número e de valor de volume, finalizando a sistematização de procedimentos para classificação das vazões outorgadas.

A Figura 4.1 apresenta uma sistematização do procedimento para classificação das vazões outorgadas, segundo sua significância em uma determinada bacia:

Divisão da bacia em trechos, podendo ser rios, afluentes ou reservatórios (condições de oferta)

Sistematização das vazões outorgadas nos trechos (condições de demanda)

Cálculo do Comprometimento Individual de cada uma das vazões outorgadas nos trechos

Cálculo do Comprometimento Coletivo de cada trecho
$\begin{gathered}\text { Estabelecimento de níveis de exigência quanto ao monitoramento, } \\ \text { para definição de diferentes tipos de controle das vazões outorgadas }\end{gathered}$
Criação de índices absolutos e relativos para classificação das vazões outorgadas
nos níveis de exigência de monitoramento estabelecidos
Definição de indicadores gerais para estabelecer valores numéricos para
os índices absolutos e relativos criados, e possibilitar a classificação
de cada vazão outorgada numa determinada categoria de monitoramento
Classificação final de cada vazão outorgada em um dos níveis de
exigência de monitoramento estabelecidos


Figura 4.1 - Sistematização do procedimento para classificação das vazões outorgadas

\subsection{ESTUDO DE CASO DA BACIA DO SÃO FRANCISCO}

Para teste e verificação dos procedimentos para classificação das vazões outorgadas, trabalhou-se com dados reais de trechos de domínio da União (condições de oferta) e vazões outorgadas (condições de demanda) da bacia do rio São Francisco, como estudo de caso deste trabalho.

A bacia do rio São Francisco foi escolhida por possuir trechos com diferentes características (afluentes, reservatórios, calha do rio, etc.), possibilitando então encontrar valores numéricos para os índices relativos, de forma a melhor adequar as vazões outorgadas, nos diferentes trechos, aos indicadores gerais.

Para tanto, foram criados diferentes cenários, reajustando valores para os índices absolutos e relativos, até encontrar resultados próximos aos indicadores gerais de volume e número de vazões estabelecidos nos procedimentos anteriores, levando à classificação final das vazões outorgadas da bacia do São Francisco, objeto do estudo de caso.

\subsection{FLUXOGRAMA PARA POSSIBILITAR CONSTRUÇÃO DE SSD PARA CONTROLE DAS VAZÕES OUTORGADAS}

Finalizando, com os resultados numéricos do estudo de caso da bacia do rio São Francisco, apresentou-se um fluxograma detalhado de forma a possibilitar a construção de um sistema de suporte de decisão para controle das vazões outorgadas, levando em conta diferentes níveis de exigência quanto ao monitoramento de vazões outorgadas em uma determinada bacia, classificando as vazões outorgadas segundo sua significância no trecho, tanto em termos individuais, como em termos coletivos, e estabelecendo a necessidade de instalação de equipamentos de medição.

O fluxograma partiu de um SSD existente para definição de outorgas, o Sistema de Controle de Bacias Hidrográficas - SCBH - elaborado por Collischonn (2014). Com as informações de oferta e demanda existentes na bacia do São Francisco, objeto do estudo de caso, foram 
definidas atividades adicionais ao SSD de outorga, sendo estas atividades um subsistema denominado "SCBH fiscalização".

Como resposta, para cada vazão outorgada na bacia do São Francisco, o fluxograma indicou um tipo de monitoramento a ser definido, recomendando os equipamentos mais adequados para instalação. 


\section{RESULTADOS E DISCUSSÃO}

De acordo com os procedimentos definidos na Metodologia, apresentam-se os resultados em quatro partes:

- Definição dos equipamentos de medição de vazão mais adequados para instalação em condutos forçados e canais abertos;

- Sistematização de procedimentos para classificação das vazões outorgadas e definição de diferentes tipos de monitoramento;

- Verificação dos procedimentos com dados reais de vazões outorgadas na bacia do rio São Francisco, como estudo de caso;

- Elaboração de fluxograma para possibilitar a construção de um sistema de suporte à decisão para controle de vazões outorgadas.

\subsection{EQUIPAMENTOS DE MEDIÇÃO DE VAZÃO PARA CADA UM DOS NÍVEIS DE MONITORAMENTO EXIGIDOS}

Como atividade relacionada ao controle dos usos outorgados, foram elaboradas tabelas com os equipamentos de medição de vazão, contendo informações quanto à aquisição, instalação, operação e manutenção, recomendações gerais, vantagens e desvantagens.

A elaboração dessas tabelas baseou-se em estudos experimentais com equipamentos de medição de vazão instalados na bacia do ribeirão Pipiripau, estudos estes apresentados no Apêndice $\mathrm{C}$ do presente trabalho. Além dos estudos práticos realizados com trabalho de campo, foram agregadas informações obtidas em pesquisa, constantes das referências bibliográficas, e consulta aos fabricantes dos referidos equipamentos de medição.

As tabelas contemplam a classificação do ponto de interferência em um dos três níveis de monitoramento, ou seja, são apresentadas tabelas com equipamentos para cada um dos três níveis de exigência, constantes do Apêndice D desta dissertação. 


\subsection{SISTEMATIZAÇÃO DE PROCEDIMENTOS PARA CLASSIFICAÇÃO DAS VAZÕES OUTORGADAS}

Conforme descrito no item 4.2 da Metodologia, foram desenvolvidos os procedimentos para classificação das vazões outorgadas, com base nas características da bacia em estudo e na importância absoluta e relativa das referidas vazões. O detalhamento de cada um desses procedimentos é apresentado a seguir:

\subsubsection{Divisão da bacia em trechos}

O primeiro passo do trabalho é a delimitação de uma área, a fim de que se possa estabelecer as informações de disponibilidade hídrica e, por conseguinte, as condições de oferta.

São realizados estudos de vazões outorgadas em águas superficiais, e a área de estudo pode ser um rio, um trecho de rio ou um reservatório. O importante é que nessa região esteja estabelecida uma disponibilidade hídrica, dada por uma vazão de referência, num determinado trecho i - Qreferencia (i), vazão esta considerada que representa o limite superior de utilização da água em um determinado curso d'água, podendo ser, por exemplo, a Q 7,10 (vazão média mínima de sete dias consecutivos com período de retorno de 10 anos), a Q90 ou a Q95 (vazões com garantia de 90 e 95\%, respectivamente, de permanência dentro da série histórica de dados observada).

\subsubsection{Vazões outorgadas e condições de demanda}

A demanda é caracterizada por vazões outorgadas no trecho, que podem ser de captação ou de lançamento. Para cada um dos pontos de interferência relacionados a essas vazões, será associado um valor de vazão de demanda $\mathbf{Q}_{\text {demanda, em 1/s. }}$.

Para cada ponto de captação, $Q_{\text {demanda }}$ corresponde aos dados de vazão máxima instantânea outorgada, em 1/s. Cabe aqui lembrar que o valor máximo instantâneo, normalmente representado pela capacidade nominal do sistema, se diferencia das vazões de análise para a outorga. De fato, a vazão outorgada pelos órgãos gestores de recursos hídricos, em geral, é representada pela vazão média de captação ou lançamento, podendo ser a média diária ou a 
média mensal. No entanto, levando-se em conta a necessidade de medição e o valor real apropriado pelo usuário, este valor pode ser maior ou igual ao outorgado.

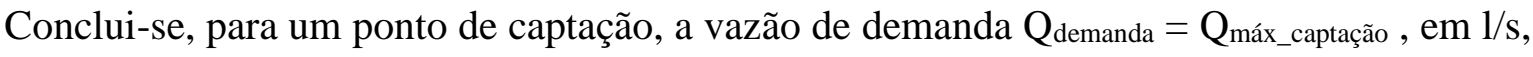
sendo $Q_{\text {máx_captação }} \geq Q_{\text {outorgada. }}$

Para cada ponto de lançamento, deve-se levar em conta a denominada vazão de diluição, representada pela quantidade de água no corpo hídrico necessária para diluir o efluente lançado. O cálculo da vazão de diluição adotado no presente trabalho segue a fórmula proposta por Kelman (1997) e utilizada pelos órgãos gestores de recursos hídricos, adaptada para valores máximos instantâneos. Assim:

$$
\mathrm{Q}_{\text {máx_diluição }}=\mathrm{Q}_{\text {máx_efluente }} \times \frac{\left(\mathrm{DBO}_{\text {máx_efluente }}-\mathrm{DBO}_{\text {permitida }}\right)}{\mathrm{DBO}_{\text {permitida }}-\mathrm{DBO}_{\text {natural }}}
$$

Em que:

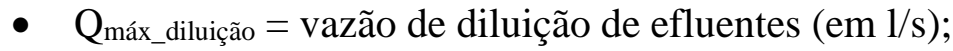

- Qmáx_efluente = vazão máxima de lançamento do efluente doméstico ou industrial (em 1/s), definida pela capacidade máxima instalada do sistema. No mesmo caso da captação, esta vazão é maior ou igual à outorgada, uma vez que, para os parâmetros de outorga, pode-se levar em conta a média diária ou a média mensal;

- $\mathrm{DBO}_{\text {máx_efluente }}=\mathrm{DBO}_{5,20}$, ou seja, Demanda Bioquímica de Oxigênio, medida durante um período de 5 dias a uma temperatura de $20^{\circ} \mathrm{C}$, sendo esta a concentração máxima do efluente doméstico ou industrial outorgado e lançado do rio (tratado ou não), medida em mg/l;

- $\quad \mathrm{DBO}_{\text {permitida }}=\mathrm{DBO}_{5,20}$ permitida para o corpo hídrico, dada pelo seu enquadramento. Ex: para um corpo hídricos enquadrado na classe 2, a DBO permitida corresponde a $5 \mathrm{mg} / \mathrm{l}$

- $\mathrm{DBO}_{\text {natural }}=\mathrm{DBO}_{5,20}$ natural do trecho de rio (mg/l). Admite-se, no presente trabalho, o mesmo valor adotado pelos órgãos gestores de recursos hídricos para outorgas de diluição, sendo $\mathrm{DBO}_{\text {natural }}=1 \mathrm{mg} / \mathrm{l}$, valor este definido por Klein (1962) apud von Sperling (1998), para um rio bastante limpo, decorrente somente de matéria orgânica oriunda de folhas e galhos de árvore, peixes mortos, fezes de animais, etc. 
Após o cálculo da vazão de diluição, para um ponto de lançamento calcula-se a vazão indisponível máxima instantânea, somando a vazão máxima instantânea do efluente lançado $\left(\mathrm{Q}_{\text {máx_efluente }}\right)$ com a vazão de diluição máxima instantânea $\left(\mathrm{Q}_{\text {máx_diluição }}\right)$ :

$$
\mathrm{Q}_{\text {máx_indisp. }}=\mathrm{Q}_{\text {máx_efluente }}+\mathrm{Q}_{\text {máx_diluição }}
$$

As vazões outorgadas pelos órgãos gestores correspondem à vazão indisponível, e não a vazão de diluição. Lembrando que está sendo considerado, para o presente trabalho, os valores máximos instantâneos de vazão, podendo estes serem iguais ou superiores aos valores outorgados. Portanto, Qmáx_indisponível $\geq$ Q indisponível_outorgado.

Concluindo, para pontos de lançamento, as vazões de demanda $\mathrm{Q}_{\text {demanda }}$ correspondem às

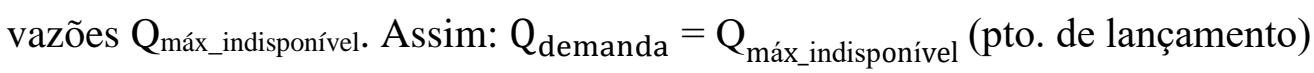

No que diz respeito aos dados da demanda, são levados em conta a questão da propagação das vazões outorgadas nos trechos anteriores. Ou seja, para cada trecho de rio, com determinada vazão de referência $Q_{\text {referencia }}(i)$, está associado, além das vazões outorgadas no próprio trecho i, consideradas neste trabalho como vazões de demanda $\mathrm{Q}_{\text {demanda }}(\mathrm{i})$, as vazões de demanda outorgadas nos trechos anteriores, ou seja, $\sum_{1}^{\mathrm{i}-1} \mathrm{Q}_{\text {demanda }}(\mathrm{n})$, podendo ser denominado somatório das vazões de montante $\left(\Sigma Q_{\text {montante }}\right)$.

O importante é que, num trecho i específico, o armazenamento de vazões de demanda outorgadas deve possibilitar a entrada de novas vazões. Além disso, que essas novas vazões de demanda outorgadas, inseridas num determinado trecho i, sejam somadas às vazões de montante $\left(\Sigma \mathrm{Q}_{\text {montante }}\right)$ dos trechos subsequentes $(\mathrm{i}+\mathrm{n})$, de forma a contemplar a propagação das demandas nos demais trechos da bacia.

\subsubsection{Cálculo do Comprometimento Individual}

Para cada ponto de interferência, seja de captação ou lançamento, tendo sido calculado a $\mathrm{Q}_{\text {demanda }}$ e sabendo qual o trecho em que o referido ponto está localizado, ou seja, sabendo a vazão de referência $Q_{\text {referencia }}$ do trecho i, tem-se:

$$
\mathrm{ICI}_{\text {máx }}=\mathrm{ICI}_{\text {demanda }}=\frac{\mathrm{Q}_{\text {demanda }}}{\mathrm{Q}_{\text {referência }}(\mathrm{i})}
$$


Tem-se, então a variável denominada Indicador de Comprometimento Individual Máximo (ICImáx). Este indicador é adimensional e corresponde ao comprometimento individual de cada ponto de interferência no trecho i, levando em conta que a vazão de demanda é a vazão máxima instantânea.

\subsubsection{Cálculo do Comprometimento Coletivo}

Tendo sido feito o cálculo do $\mathrm{ICI}_{\max }$ para cada uma das vazões de demanda outorgadas num trecho i, o próximo passo é o cálculo do Indicador de Comprometimento Coletivo Máximo (ICC $\left.\mathbf{C}_{\text {máx }}\right)$. Este indicador também é adimensional e corresponde ao comprometimento coletivo no trecho i, sendo alterado para cada vazão outorgada que seja inserida no referido. Leva em conta não só as vazões de demanda no trecho i, mas também as vazões de demanda dos trechos de montante. Uma vez que o cálculo das vazões de demanda está associado às vazões máximas instantâneas, então também é denominado "máximo". Calcula-se, então, para cada trecho:

$$
\mathrm{ICC}_{\text {máx }}=\frac{\sum_{1}^{\mathrm{i}-1} \mathrm{Q}_{\text {demanda }}(\mathrm{n})+\sum \mathrm{Q}_{\text {demanda }}(\mathrm{i})}{\mathrm{Q}_{\text {referência }}(\mathrm{i})}=\frac{\sum \mathrm{Q}_{\text {montante }}+\sum \mathrm{Q}_{\text {demanda }}(\mathrm{i})}{\mathrm{Q}_{\text {referência }}(\mathrm{i})}
$$

\subsubsection{Estabelecimento de níveis de exigência quanto ao monitoramento das vazões outorgadas}

Como definição inicial para atendimento à necessidade de controle dos usos outorgados, parte-se do pressuposto da Resolução $n^{\circ}$ 16/2001 do CNRH, de que todo usuário outorgado deve implantar e manter o monitoramento da vazão captada e/ou lançada e da qualidade do efluente.

A necessidade de monitoramento do uso, por parte do outorgado, é condição para obtenção de seu direito de uso. A razoabilidade dessa exigência de monitoramento do uso outorgado vai ao encontro de atingir um dos objetivos da PNRH, preconizado no inciso II do Art. $2^{\circ}$ da lei 9.433/1997, que tem como meta utilização racional e integrada dos recursos hídricos, com vistas ao desenvolvimento sustentável (Brasil, 1997).

Dessa forma, tomando um ponto outorgado em um determinado rio, trecho de rio ou reservatório, com uma mesma vazão de referência, definem-se exigências para estabelecimento 
de um monitoramento do seu uso, de forma gradativa, a depender da significância do ponto no trecho. Assim, quanto mais significante for o ponto outorgado no trecho, maior a exigência para controle do uso.

Para monitoramento do uso de recursos hídricos outorgado, a fim de se conhecer o real uso em campo, devem ser controlados, com maior ou menor precisão: a vazão, o tempo de funcionamento, e a $\mathrm{DBO}_{5,20}$, quando se tratar de outorga de diluição.

Cabe aqui mencionar que deve ser levada em conta a sazonalidade como critério para autorização do uso, conforme recomendado por Cruz (2001) e Rosa de Oliveira et al. (2013). Tal fato permite uma melhor utilização do recurso, alocando mais água nos meses de maior disponibilidade e menos nos meses mais críticos.

Leva-se então à autorização de um volume mensal outorgado, que leva em conta a vazão outorgada em 1/s, multiplicada pelo $\mathrm{n}^{\circ}$ de horas/dia e pelo $\mathrm{n}^{\circ}$ de dias/mês. No que diz respeito então ao controle do uso e fins de comparação, o monitoramento a ser exigido tem como resposta final o volume mensal utilizado ou apropriado pelo outorgado.

A seguir, definem-se três níveis gradativos para controle do uso outorgado, onde as vazões outorgadas num trecho i serão classificadas, levando em conta a vazão, o tempo e, por consequência, o volume, além da $\mathrm{DBO}_{5,20}$ do efluente, caso de lançamento.

\subsubsection{Nível 1 - Monitoramento simplificado}

Nesse $1^{\circ}$ nível, exige-se que os dados relativos aos parâmetros outorgados sejam simplesmente os declarados pelo usuário. Tem-se que a vazão máxima de captação ( $Q_{\text {máx_captação) ou }}$ do efluente lançado ( $\left.Q_{\text {máx_efluente }}\right)$, necessários para o cálculo da vazão de demanda ( $\left.Q_{\text {demanda }}\right)$, podem ser os estabelecidos na capacidade nominal do sistema, ou seja, declarados pelo usu-

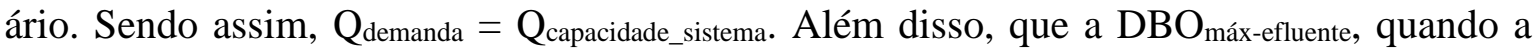
vazão outorgada for de lançamento, também seja um valor de projeto, declarado. Já o tempo de funcionamento do sistema mensal ( $\left.\mathrm{T}_{\text {mensal }}\right)$ pode ser estabelecido por meio de anotações de horas de uso/dia e de dias/mês, totalizando a estimativa mensal de uso, ou seja, $T_{\text {estimado. }}$ 
O volume mensal apropriado pelo usuário de recursos hídricos, relativa à vazão outorgada, corresponde a uma estimativa da vazão de demanda multiplicado pelas horas de funcionamento mensal anotadas. Assim:

$\mathbf{V}_{\text {mensal_1}{ }^{\circ} \text { nível }}=\mathbf{Q}_{\text {capacidade_sistema }} \times T_{\text {estimado }}$

$\mathrm{V}_{\text {mensal_1 }} 1^{\circ}$ nível $=$ volume mensal utilizado, $1^{\circ}$ nível de exigência, em $\mathrm{m}^{3} / \mathrm{mês}$;

$\mathrm{Q}_{\text {capacidade_sistema }}=$ vazão máxima (valor de projeto, capacidade do sistema);

$\mathrm{T}_{\text {estimado }}=$ anotação de horas/dia e de dias/mês de funcionamento.

Para facilitar e ordenar as informações a serem obtidas, e bem como sistematizá-las, o usuário outorgado deve manter registrados os volumes mensais, de forma a obter, ao longo do ano, dados do volume anual apropriado.

\subsubsection{Nível 2 - Monitoramento intermediário}

O $2^{\circ}$ estágio se caracteriza por um nível de exigência maior, com valores medidos. A vazão de demanda $\left(\mathrm{Q}_{\text {demanda }}\right)$ deve ser obtida por meio de um equipamento que faça uma medição instantânea no ponto de interferência, com frequência mínima anual ( $\left.Q_{\text {medida_anual }}\right)$, diferentemente do $1^{\circ}$ estágio que pode ser considerada somente a vazão de projeto. De forma similar, em termos qualitativos, a concentração máxima de $\mathrm{DBO}_{5,20}$ de lançamento pode ser obtida por dados de auto monitoramento ou por laboratório, com frequência mínima anual, sendo capaz de aproveitar os dados já exigidos na licença ambiental.

No que diz respeito ao tempo de funcionamento do sistema instalado, deve haver um monitoramento objetivo de utilização, não somente anotação das horas de funcionamento. Para tanto, requer que seja instalado um horímetro ou uma chave de fluxo, capaz de informar o período de funcionamento do sistema $\left(\mathrm{T}_{\text {registrado }}\right)$. Concluindo, o volume mensal apropriado pelo usuário de recursos hídricos, relativo ao ponto de interferência, corresponde a uma vazão máxima medida, podendo ser pontual (frequência mínima anual), multiplicada pelas horas de funcionamento mensal registradas por contador de tempo. Ou seja:

$\mathbf{V}_{\text {mensal_2 }}{ }^{\circ}$ nível $=$ Qmedida_anual $\mathbf{x}$ T $\mathbf{T}_{\text {registrado }}$

$\mathrm{V}_{\text {mensal_2 } 2^{\circ} \text { nível }}=$ volume mensal utilizado, $2^{\circ}$ nível de exigência, em $\mathrm{m}^{3} / \mathrm{mês}$;

Qmedida_anual = vazão instantânea máxima (medida, frequência mínima anual);

$\mathrm{T}_{\text {registrado }}=$ horímetro ou chave de fluxo, ou também equipamento de medição, em $\mathrm{h}$. 
Assim como nos usuários enquadrados no $1^{\circ}$ nível, para o $2^{\circ}$ nível as informações de volumes mensais devem ser registradas, de forma a obter, ao longo do ano, dados do volume anual apropriado.

\subsubsection{Nível 3 - Monitoramento avançado}

Nesse $3^{\circ}$ estágio, o usuário deverá instalar um medidor de vazão no ponto de interferência, capaz de realizar a totalização volumétrica demandada pelo referido ponto, pela integralização da vazão instantânea multiplicada pelo tempo de funcionamento.

A instalação do medidor deverá ser de acordo com o tipo de interferência, e seguir as recomendações dos fabricantes. No caso do ponto de lançamento, o usuário deverá possuir os dados de $\mathrm{DBO}_{5,20}$ feitos por auto monitoramento ou por laboratório, com frequência mínima mensal, podendo ser os dados exigidos na licença ambiental.

$V_{\text {mensal_3 }}{ }^{\circ}$ nível $=V_{\text {calculado_equipamento }}=Q_{\text {medida_contínua }} \times T_{\text {registrado. }}$

$\mathrm{V}_{\text {mensal_} 3^{\circ} \text { nível }}=$ volume mensal utilizado, $3^{\circ}$ nível de exigência, em $\mathrm{m}^{3} / \mathrm{mês}$;

$\mathrm{Q}_{\text {medida_contínua }}=$ vazão instantânea medida pelo equipamento, $\mathrm{em} \mathrm{m}^{3} / \mathrm{h}$;

$\mathrm{T}_{\text {registrado }}=$ tempo registrado pelo equipamento de medição (totalizador), em $\mathrm{h}$.

No $3^{\circ}$ nível, além da questão de instalação de equipamento medidor de vazão com totalização volumétrica, os valores de volumes mensais registrados devem ser enviados ao órgão gestor outorgante, sendo este envio de frequência anual. Uma vez que se exige a instalação de um equipamento de medição, e que o usuário represente uma maior significância se comparado aos de $1^{\circ}$ e $2^{\circ}$ nível, tanto em termos individuais, quanto em termos coletivos, é razoável que os dados medidos pelo equipamento sirvam para verificação da compatibilidade entre o volume outorgado e o real uso em campo.

Cabe informar que já é adotado, para alguns estados, uma declaração anual contendo os volumes mensais apropriados, denominada Declaração Anual de Uso de Recursos Hídricos (DAURH). Então, como exigência para pontos outorgados que se enquadrem no $3^{\circ}$ nível será adotado o envio, com periodicidade anual, da DAURH. 
Em bacias com problemas reais de conflito pelo uso de recursos hídricos, como por exemplo as bacias do Paraíba do Sul e do Piracicaba, Capivari e Jundiaí nos anos de 2015 e 2016, podem ser estabelecidas mais exigências para as vazões outorgadas e classificadas no nível 3. Isso se deve ao fato da necessidade dos órgãos gestores de recursos hídricos conhecerem a real demanda em períodos mais curtos, como os períodos de seca, e poder fazer um planejamento e estabelecer restrições de uso que minimizem o prejuízo dos usuários outorgados.

Dessa forma, para a contabilização, registro e até mesmo envio dos dados de vazão medidos, além de possuírem o equipamento instalado, as vazões outorgadas no nível 3 em condições críticas devem instalar um data logger capaz de armazenar os dados medidos e transmitir ao órgão gestor, numa periodicidade mensal, se assim o exigir.

Resumindo, segue tabela comparativa entre os estágios criados, com detalhe das atividades de monitoramento do uso estabelecidos como exigência para cada um dos três estágios:

Tabela 5.1 - Exigência para os usuários outorgados, para cada um dos três estágios de classificação quanto ao uso de recursos hídricos

\begin{tabular}{|c|c|c|c|c|}
\hline $\begin{array}{c}\text { Exigência a } \\
\text { ser estabele- } \\
\text { cida }\end{array}$ & $\begin{array}{c}1^{\circ} \text { Nível: } \\
\text { Monitoramento } \\
\text { Simplificado }\end{array}$ & $\begin{array}{c}2^{\circ} \text { Nível: } \\
\text { Monitoramento } \\
\text { Intermediário }\end{array}$ & $\begin{array}{c}3^{\circ} \text { Nível: } \\
\text { Monitoramento } \\
\text { Avançado }\end{array}$ & $\begin{array}{c}3^{\circ} \text { Nível*: } \\
\text { Monitoramento } \\
\text { Avançado em } \\
\text { bacias críticas }\end{array}$ \\
\hline $\begin{array}{l}\text { Tempo de } \\
\text { utilização }\end{array}$ & $\begin{array}{l}\text { Estimativa (ano- } \\
\text { tação das horas } \\
\text { de uso) }\end{array}$ & $\begin{array}{l}\text { Medidor de } \\
\text { tempo (horímetro } \\
\text { ou chave de } \\
\text { fluxo) }\end{array}$ & $\begin{array}{l}\text { Medidor de vazão } \\
\text { com totalizador } \\
\text { de volume }\end{array}$ & $\begin{array}{l}\text { Armazenamento } \\
\text { em data logger }\end{array}$ \\
\hline $\begin{array}{l}\text { Medição da } \\
\text { vazão (cap- } \\
\text { tação ou lan- } \\
\text { çamento) }\end{array}$ & $\begin{array}{l}\text { Valor de projeto } \\
\text { (capacidade ins- } \\
\text { talada) }\end{array}$ & $\begin{array}{l}\text { Valor medido por } \\
\text { equipamento (fre- } \\
\text { quência anual) }\end{array}$ & $\begin{array}{l}\text { Valor medido por } \\
\text { equipamento ins- } \\
\text { talado (contínuo) }\end{array}$ & $\begin{array}{l}\text { Valor medido } \\
\text { por equipamento } \\
\text { e armazenado } \\
\text { em data logger }\end{array}$ \\
\hline $\begin{array}{l}\text { Volume men- } \\
\text { sal de água } \\
\text { consumido }\end{array}$ & $\begin{array}{l}V_{\text {mensal 1ํóvel }}= \\
Q_{\text {capac-sistema }} \mathrm{X} \\
\mathrm{T}_{\text {estimado }}\end{array}$ & $\begin{array}{l}\mathrm{V}_{\text {mensal_2} 2^{\circ} \text { nível }}= \\
\mathrm{Q}_{\text {med-anual }} \mathrm{X} \mathrm{T}_{\text {regis- }} \\
\text { trado }\end{array}$ & $\begin{array}{l}\mathrm{V}_{\text {mensal_3onível }}= \\
\mathrm{V}_{\text {calculado-equip. }}= \\
\mathrm{Q}_{\text {contínua }} \mathrm{X} \mathrm{T}_{\text {registrado }}\end{array}$ & $\begin{array}{l}\mathrm{V}_{\text {mensal_3} 3^{\circ} \text { nível }}= \\
\mathrm{V}_{\text {calculado-equip. }}= \\
\mathrm{Q}_{\text {contínua }} \mathrm{X} \mathrm{T}_{\text {armaze- }} \\
\text { nado_logger }\end{array}$ \\
\hline $\begin{array}{l}\text { DBO má- } \\
\text { xima }\end{array}$ & Valor de projeto & $\begin{array}{l}\text { Medido (frequên- } \\
\text { cia mínima anual) }\end{array}$ & $\begin{array}{l}\text { Medido (frequên- } \\
\text { cia mínima men- } \\
\text { sal) }\end{array}$ & $\begin{array}{l}\text { Medido (fre- } \\
\text { quência mínima } \\
\text { mensal) }\end{array}$ \\
\hline $\begin{array}{l}\text { Envio de in- } \\
\text { formações } \\
\text { ao órgão } \\
\text { gestor }\end{array}$ & $\begin{array}{l}\text { Não há necessi- } \\
\text { dade }\end{array}$ & $\begin{array}{l}\text { Não há necessi- } \\
\text { dade }\end{array}$ & $\begin{array}{l}\text { Envio dos volu- } \\
\text { mes mensais me- } \\
\text { didos (frequência } \\
\text { anual - DAURH) }\end{array}$ & $\begin{array}{l}\text { Envio dos volu- } \\
\text { mes mensais } \\
\text { medidos (fre- } \\
\text { quência mensal } \\
\text { - se necessário) }\end{array}$ \\
\hline
\end{tabular}




\subsubsection{Criação de índices para classificação dos pontos de interferência outorgados}

Tomando a região espacial definida por um rio, trecho de rio ou reservatório, um trecho i, com determinada $Q_{\text {referência }}(\mathrm{i})$, bem como as vazões outorgadas nesse trecho, e partindo da definição de três níveis para classificação os pontos quanto ao monitoramento (simplificado, intermediário e avançado), criam-se índices, como critérios específicos, para realizar a classificação desses pontos em um dos três níveis gradativos de exigência. Para criação desses índices de classificação, consideram-se dois aspectos:

- Em termos absolutos: deve-se levar em conta valores mínimos e máximos de vazão de cada ponto de interferência outorgado, para estabelecimento comparativo de significância de uso;

- Em termos relativos: deve ser considerada a região onde o empreendimento está instalado, que possui uma certa vazão de referência, a fim de verificar o comprometimento individual do usuário no local, e levar em conta também qual o comprometimento coletivo instaurado nessa região.

Sendo assim, levando em conta a questão da localização do ponto, e valores de mínimo e máximo, estabelecem-se três índices para classificação do ponto de interferência em termos absolutos e cinco índices em termos relativos. Esses índices vão levar em conta os conceitos anteriormente descritos de Comprometimento Individual e Comprometimento Coletivo.

Esses índices servem para classificar as vazões outorgadas devendo, portanto, serem encontrados valores numéricos. A seguir, apresentam-se os índices, separando-os em termos absolutos e relativos, com definição para cada um deles, estipulando valores numéricos iniciais, tomados como exemplo para definição de critérios de outorga.

\subsubsection{1 Índices Absolutos}

Os índices absolutos levam em conta critérios quantitativos de vazão dos pontos outorgados, além do porte do rio. Separam os pontos outorgados num dos três níveis de classificação pela vazão de demanda de cada um deles em termos de mínimo e máximo. Os pontos outorgados com menor vazão de demanda são classificados no $1^{\circ}$ nível (Monitoramento Simplificado), em termos de mínimo, e os pontos com maior vazão de demanda são classificados 
nos outros dois níveis (Intermediária e Avançado), em termos de máximo. Seguem as definições de cada um dos índices:

QAB1 - relacionado a uma vazão absoluta mínima, este parâmetro serve como referência para classificar um usuário no $1^{\circ}$ estágio. Sendo assim, se a vazão de demanda do ponto de interferência for menor que QAB1, o ponto de interferência pertencerá ao $1^{\circ}$ estágio (monitoramento simplificado).

$$
\mathrm{Q}_{\text {demanda }}<\mathrm{QAB} 1 \rightarrow 1^{\circ} \text { Estágio (Monitoramento Simplificado) }
$$

Como exemplo para definição de valores absolutos de mínimo, para classificação de vazões outorgadas diretamente no Estágio 1 - monitoramento simplificado, toma-se como referência medições de vazão realizadas na prática, em usuários de menor porte. Nas medições de vazão realizadas pela equipe de fiscalização da ANA entre 2004 e 2014, em condutos forçados, utilizando equipamento ultrassônico de vazão por tempo de trânsito, tem-se uma limitação do diâmetro da tubulação para ser efetuada uma correta medição, que deve ser maior ou igual a 3" (75mm). Levando em conta medições em usuários com tubulações de 75 a $100 \mathrm{~mm}$, com captação por bomba com motor de 7,5 a $15 \mathrm{cv}$, verificou-se que, para interferências deste porte, as vazões variam de 5 a 15 1/s. Para usuários outorgados deste porte, até em regiões de conflito, constatou-se em trabalhos realizados pela fiscalização ser mais importante ter o conhecimento de quantas interferências há, e se estão ativas ou não, do que os reais valores de vazão utilizados. Ou seja, apesar de se constituírem vazões outorgadas, não seria necessário ao usuário imputar uma exigência de monitoramento intermediário (horímetro), muito menos avançado (instalação de equipamento), sendo suficiente que ele faça um monitoramento simplificado para que se tenha ciência do funcionamento. Dessa forma, tomando um valor intermediário entre as vazões de menor porte verificadas em campo, adota-se QAB1 = 10 1/s. Ou seja, neste cenário, uma vazão outorgada é classificada automaticamente para Estágio 1 - Simplificado quando $Q_{\text {demanda }}<101 / \mathrm{s}$.

$\underline{\text { QAB2 }}$ - relacionado a uma vazão absoluta máxima, este parâmetro serve como referência para classificar uma vazão outorgada diretamente no $3^{\circ}$ estágio. Sendo assim, se $\mathrm{Q}_{\text {demanda }} \geq$ QAB2, o ponto de interferência deverá ter monitoramento avançado com instalação de equipamento de medição de vazão. Dessa maneira, do índice QAB2 tem-se:

$$
\mathrm{Q}_{\text {demanda }}>\mathrm{QAB} 2 \rightarrow 3^{\circ} \text { Estágio (Monitoramento avançado) }
$$


O valor absoluto máximo QAB2 enquadra um usuário outorgado diretamente no monitoramento de nível 3, ou seja, deve instalar equipamento de medição e enviar informações de consumo ao órgão gestor. Estipula-se uma classificação direta no último nível de monitoramento, independentemente do local instalado, simplesmente pela vazão outorgada.

Para definição de um valor inicial para este índice, tomou-se como exemplo os perímetros de irrigação outorgados à CODEVASF na bacia do rio São Francisco. De acordo com levantamento realizado por Pereira et al (2011), tomando uma média das vazões outorgadas aos perímetros de irrigação na referida bacia, adota-se QAB2 $=500$ 1/s. Dessa forma, quando $\mathrm{Q}_{\text {demanda }}>5001 / \mathrm{s}$, uma vazão outorgada é classificada automaticamente no Nível 3 - Monitoramento Avançado, com instalação de equipamento de medição, independente das condições locais. A ideia nesse caso é estabelecer que uma vazão outorgada é significativa pelo seu valor em si, independente da região, e que um usuário com $\mathrm{Q}_{\text {demanda }}$ superior a 5001/s deve realizar um monitoramento objetivo do uso outorgado pela instalação de um equipamento de medição de vazão e, além disso, tem condições de fazê-lo, pelo porte do empreendimento.

\subsubsection{2 Índices Relativos}

Tendo sido definidos os limites absolutos, para classificação direta das vazões outorgadas num dos três estágios, sendo de mínimo para o Estágio 1, e de máximo para os Estágios 2 e 3, os valores outorgados que estão entre os limites de mínimo e máximo absoluto são classificados por valores relativos.

Os índices absolutos, portanto, já levam à classificação de algumas vazões num trecho i a serem classificadas no $1^{\circ}$ Nível (Simplificado), tendo em vista valores outorgados abaixo do mínimo absoluto QAB1; e no $3^{\circ}$ Nível (Avançado) por vazões de outorga acima do máximo absoluto QAB2. O restante das vazões outorgadas, entre QAB1 e QAB2, são classificadas por índices relativos, que vão levar em conta o Comprometimento Individual (relação entre a vazão de demanda do ponto e a vazão de referência do trecho i), e Comprometimento Coletivo (relação entre todas as vazões outorgadas no trecho i com a vazão de referência do mesmo).

$\mathrm{QAB} 1 \leq \mathrm{Q}_{\text {demanda }} \leq \mathrm{QAB} 2 \rightarrow$ Verificação com base em valores relativos 
Para melhor visualização, a faixa para classificação da vazão de demanda em termos absolutos e relativos é expressa graficamente a seguir:

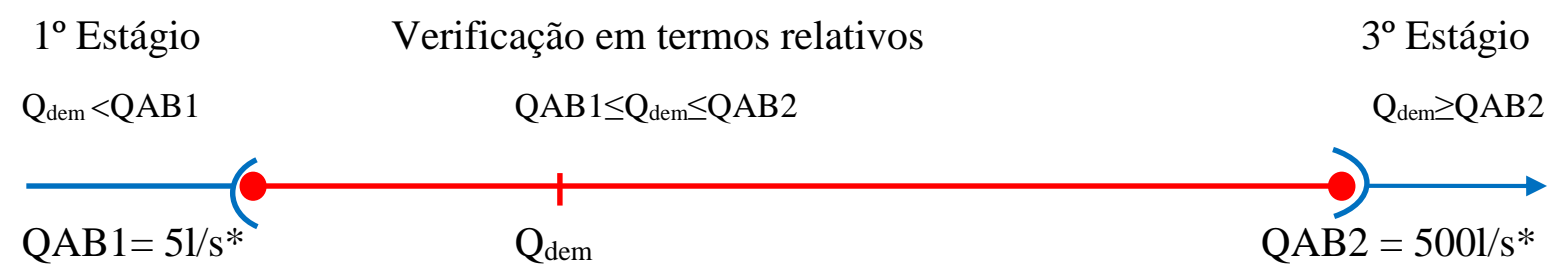

* Valores absolutos iniciais e citados como exemplo, a serem verificados posteriormente A verificação do estágio, em termos relativos, será de acordo com a comparação da vazão de demanda $\left(\mathrm{Q}_{\text {demanda }}\right)$ do ponto de interferência com a vazão de referência $\mathrm{Q}_{\text {referencia }}(\mathrm{i})$ do trecho. De acordo com o Indicador de Comprometimento Individual Máximo (ICI máx ) calculado para cada ponto de interferência, e o Indicador de Comprometimento Coletivo Máximo $\left(\mathrm{ICC}_{\text {máx }}\right)$ calculado para cada trecho i, tem-se:

$\underline{\mathbf{P C C}}$ - índice de relevância do Indicador de Comprometimento Coletivo Máximo ( ICC $\left._{\text {máx }}\right)$ do trecho. Se $\mathrm{ICC}_{\max }<\mathrm{PCC}$, o trecho do rio se encontra com comprometimento coletivo menos relevante. Por outro lado, se $\mathrm{ICC}_{\max } \geq \mathrm{PCC}$, o trecho se encontra com comprometimento coletivo mais acentuado.

Quanto a exemplos de valores numéricos para representação do índice coletivo PCC, podese levar em consideração os critérios para outorga adotados nos Manuais de Outorga da ANA e dos seguintes Estados Brasileiros:

- Manual de Outorga da ANA: constante do Anexo I da Resolução ANA nº 1041, de 19 de agosto de 2013, prevê a situação de comprometimento coletivo normal, para análise de outorga, quando a disponibilidade hídrica se encontra abaixo de 70\%; na situação de alerta, se está no intervalo entre 70 e 100\%; e crítica, se está acima de $100 \%$ (Brasil, 2013).

- Manual de Outorga da Secretaria de Meio-Ambiente e Recursos Hídricos do Estado de Goiás (Semarh/GO): considera a situação de disponibilidade hídrica normal quando está abaixo de 50\%; em situação de alerta no intervalo entre 50 e 80\%; moderadamente crítico entre 80 e $100 \%$; e altamente crítico quando for maior que $100 \%$ (Goiás, 2012). 
- Manual de Outorga da Secretaria de Estado de Meio-Ambiente e Desenvolvimento sustentável de Minas Gerais (Semad/MG): adota um critério mais conservador e prevê que, para emissão de outorgas, o limite máximo de comprometimento da disponibilidade hídrica deve estar em 30\%, e acima disto deve ser atendido somente em casos de uso prioritário, ou seja, de abastecimento humano e dessedentação animal (Minas Gerais, 2010).

Pelos critérios adotados para outorga, um valor de Indicador de Comprometimento Coletivo com maior relevância seria em torno de $50 \%$. Ou seja, para análise de fins para outorga, considera-se que um rio acima de 50\% da vazão de referência outorgada já deve ter um olhar especial, em termos de comprometimento do uso. Poderia ser adotado, inicialmente, valores mais conservadores, forçando que os trechos tenham um maior comprometimento coletivo com valores menores que 50\%. Pode-se adotar, por exemplo, $\mathrm{PCC}=0,3$. Em outras palavras, o Indicador de Comprometimento Coletivo $\mathrm{ICC}_{\text {máx }}<30 \%$ teria menor relevância num trecho de rio $\mathrm{i}$, e $\mathrm{ICC}_{\max } \geq 30 \%$ seria considerado um trecho com comprometimento coletivo mais relevante.

A partir desse índice PCC, que está relacionado ao comprometimento coletivo, verifica-se a classificação das vazões outorgadas por índices relacionados ao comprometimento individual ICI $_{\text {máx }}$, relacionando-as à vazão de referência $Q_{\text {referência }}(\mathrm{i})$. Assim:

- $\quad$ Para rios com comprometimento de menor relevância $\left(\mathrm{ICC}_{\max }<\mathrm{PCC}\right)$ :

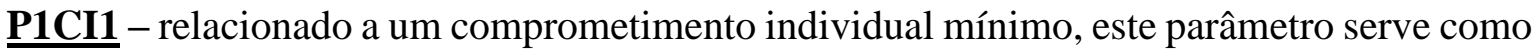
referência para classificar uma vazão outorgada no $1^{\circ}$ estágio, em rios de menor comprome-

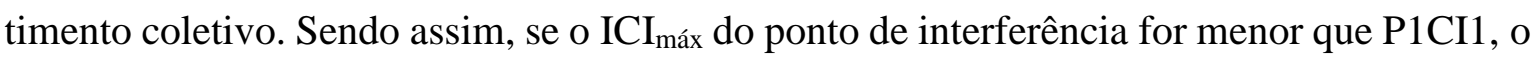
ponto de interferência pertencerá ao $1^{\circ}$ estágio (monitoramento simplificado).

$$
\mathrm{ICI}_{\text {máx }}<\mathrm{P} 1 \mathrm{CI} 1 \rightarrow 1^{\circ} \text { Estágio (Monitoramento Simplificado) }
$$

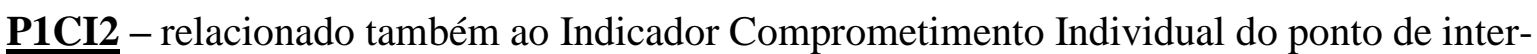
ferência, serve como parâmetro para definição entre o $2^{\circ}$ estágio (monit. intermediário) e o $3^{\circ}$ estágio (monit. avançado), em rios de menor comprometimento coletivo. Sendo assim, se o ICI $\mathrm{I}_{\text {máx }}$ do ponto de interferência for menor que P1CI2, a vazão outorgada pertencerá ao $2^{\circ}$ estágio, se for maior ou igual a P1CI2, será classificada no $3^{\circ}$ estágio. 


$$
\begin{gathered}
\mathrm{P} 1 \mathrm{CI} 1 \leq \mathrm{ICI}_{\text {máx }}<\mathrm{P} 1 \mathrm{CI} 2 \rightarrow 2^{\circ} \text { Estágio (Monitoramento Intermediário) } \\
\mathrm{ICI}_{\text {máx }} \geq \mathrm{P} 1 \mathrm{CI} 2 \rightarrow 3^{\circ} \text { Estágio (Monitoramento Avançado) }
\end{gathered}
$$

- $\quad \underline{\text { Para rios com comprometimento de maior relevância }}\left(\mathrm{ICC}_{\max } \geq \mathrm{PCC}\right)$ :

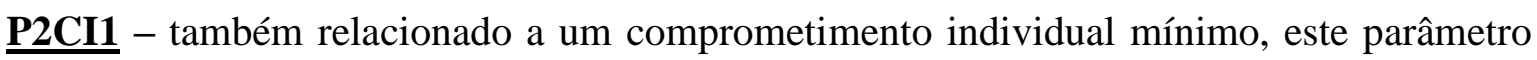
serve como referência para classificar uma vazão outorgada no $1^{\circ}$ estágio, em rios de maior comprometimento coletivo. Sendo assim, se o ICI $_{\text {máx }}$ do ponto de interferência for menor que P2CI1, a vazão outorgada pertencerá ao $1^{\circ}$ estágio (monitoramento simplificado).

$$
\mathrm{ICI}_{\text {máx }}<\mathrm{P} 2 \mathrm{CI} 1 \rightarrow 1^{\circ} \text { Estágio (Monitoramento Simplificado) }
$$

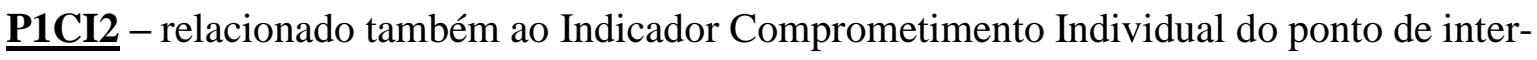
ferência, serve como parâmetro para definição entre o $2^{\circ}$ estágio (monit. intermediário) e o $3^{\circ}$ estágio (monit. avançado), em rios de maior comprometimento coletivo. Sendo assim, se o ICI máx da vazão outorgada for menor que P1CI2, o ponto de interferência pertencerá ao $2^{\circ}$ estágio, se for maior ou igual a P1CI2, a vazão será classificada no $3^{\circ}$ estágio.

$$
\begin{gathered}
\mathrm{P} 2 \mathrm{CI} 1 \leq \mathrm{ICI}_{\text {máx }}<\mathrm{P} 2 \mathrm{CI} 2 \rightarrow 2^{\circ} \text { Estágio (Monitoramento Intermediário) } \\
\mathrm{ICI}_{\text {máx }} \geq \mathrm{P} 2 \mathrm{CI} 2 \rightarrow 3^{\circ} \text { Estágio (Monitoramento Avançado) }
\end{gathered}
$$

No que tange aos índices relativos individuais (P1CI1, P1CI2, P2CI1 e P2CI2), não há referências para definição de valores iniciais como exemplos. Comparando aos critérios para definição de outorgas, somente no Manual de Outorga da ANA prevê que o limite para outorga individual a um usuário é de $20 \%$. Sendo assim, poder-se-ia partir de valores de exemplo mais conservadores, bem inferiores a 0,2 (20\%), adotando, como exemplo, P1CI1 = $0,002(0,2 \%)$ e P1CI2 = 0,01 (1\%).

Assim, um ponto de interferência localizado num trecho de menor comprometimento coletivo ( $\mathrm{ICC}_{\text {máx }}<30 \%$ ), já seria passível de monitoramento intermediário ( $2^{\circ}$ estágio) com ICImáx $\geq 0,2 \%$, e de instalar equipamento de medição ( $3^{\circ}$ estágio) com $\operatorname{ICI}_{\text {máx }} \geq 1 \%$. Já num trecho de maior comprometimento coletivo $\left(\mathrm{ICC}_{\text {máx }} \geq 30 \%\right)$, poderiam ser adotados valores pela metade dos de menor comprometimento para classificação entre os estágios, ou seja, $\mathrm{P} 2 \mathrm{CI} 1=0,001(0,1 \%)$ e P2CI2 $=0,005(0,5 \%)$. Seguindo esses valores, num trecho com maior comprometimento coletivo, uma vazão outorgada seria classificada no nível de moni- 
toramento intermediário ( $2^{\circ}$ estágio) com ICI $_{\text {máx }} \geq 0,1 \%$, e de instalar equipamento de medição ( $3^{\circ}$ estágio) com ICI $_{\text {máx }} \geq 0,5 \%$. A seguinte tabela demonstra a combinação dos índices relativos:

Tabela 5.2 - Definição dos índices relativos para classificação dos três estágios

\begin{tabular}{|c|l|c|c|}
\hline $\begin{array}{c}\text { Indicador de } \\
\begin{array}{c}\text { Comprometi- } \\
\text { mento Coletivo } \\
\text { Máximo }\end{array}\end{array}$ & \begin{tabular}{c}
$|c|$ \\
$1^{\circ}$ Estágio \\
\cline { 2 - 4 }
\end{tabular} & $\begin{array}{c}2^{\circ} \text { Estágio } \\
\text { Monit. Simplificado }\end{array}$ & $\begin{array}{c}3^{\circ} \text { Estágio } \\
\text { Monit. Avançado }\end{array}$ \\
\hline $\mathrm{ICC}_{\max }<30 \%$ & $\mathrm{ICI}_{\max }<0,2 \% *$ & $0,2 \% * \leq \mathrm{ICI}_{\max }<1 \% *$ & $\mathrm{ICI}_{\max } \geq 1 \% *$ \\
\hline $\mathrm{ICC}_{\max } \geq 30 \%$ & $\mathrm{ICI}_{\max }<0,1 \% *$ & $0,1 \% * \leq \mathrm{ICI}_{\max }<0,5 \% *$ & $\mathrm{ICI}_{\max } \geq 0,5 \% *$ \\
\hline
\end{tabular}

* Valores relativos citados como exemplo, a serem obtidos posteriormente

Cabe aqui explicitar que os parâmetros PCC, P1CI1, P1CI2, P2CI1 e P2CI2 estão relacionados aos indicadores de Comprometimento Individual (ICI máx) e Coletivo ( ICC $_{\text {máx }}$ ). Serão definidos, no presente trabalho, em termos percentuais da vazão de demanda do ponto de interferência em relação à vazão de referência do trecho i.

Finalizando, de acordo com os parâmetros outorgados, tendo sido calculada a vazão de demanda de uma vazão outorgada $\mathrm{Q}_{\text {demanda }}$ e conhecida a vazão de referência $\mathrm{Q}_{\text {referencia }}$ (i) do trecho, e levando em conta os índices absolutos e relativos criados apresenta-se, a seguir, em forma de fluxograma, a classificação de uma vazão outorgada num dos três níveis de exigência quanto ao monitoramento. 


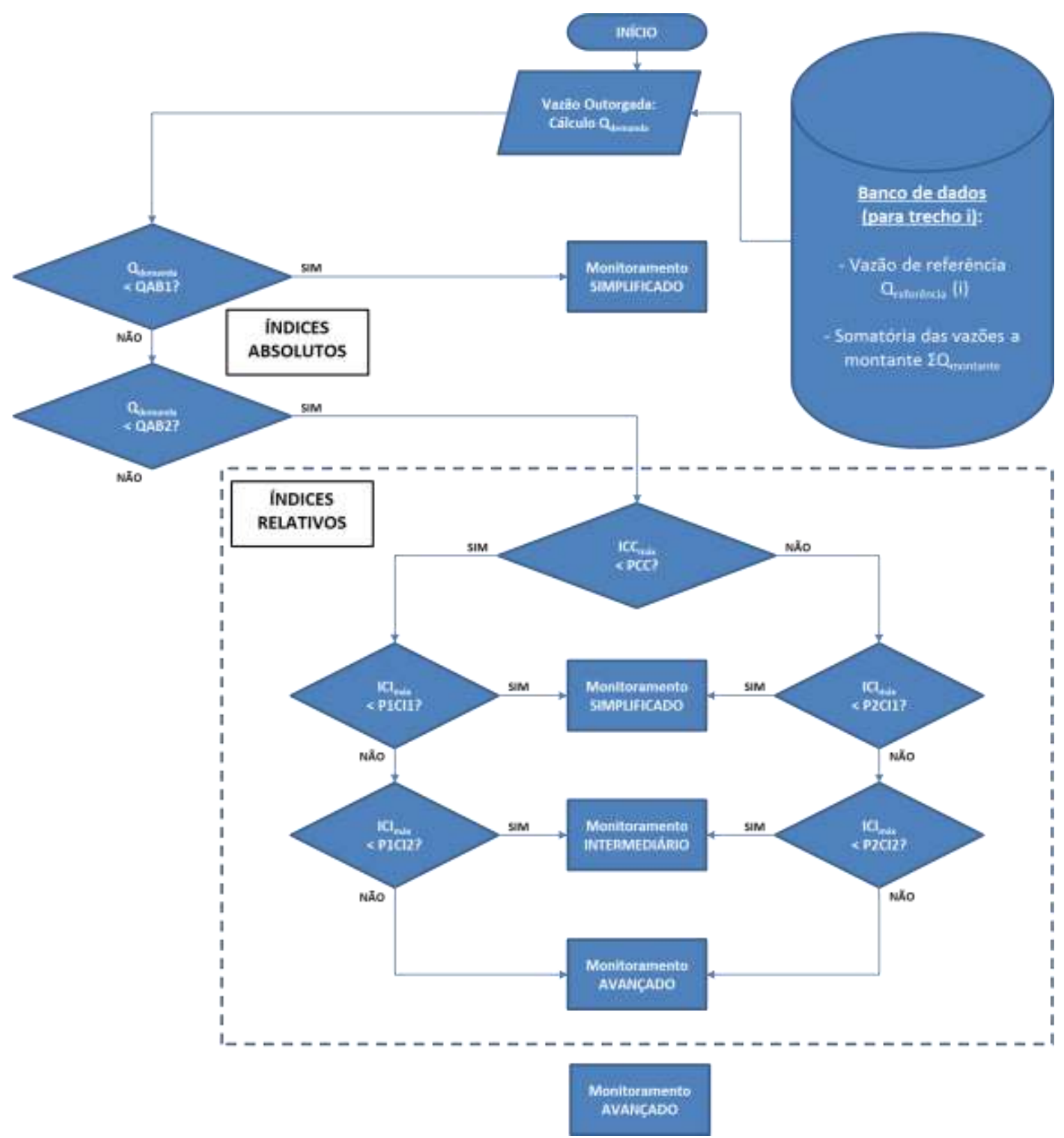

Figura 5.1 - Fluxograma de entrada de uma vazão outorgada num trecho i, com classificação num dos três níveis de monitoramento pelos índices absolutos e relativos

\subsubsection{Definição de indicadores gerais}

Conforme visto anteriormente, foram estipulados índices absolutos (QAB1 e QAB2) e índices relativos (PCC, P1CI1, P1CI2, P2CI1 e P2CI2), para possibilitar a classificação dos pontos de interferência num dos três estágios gradativos de exigência quanto ao monitoramento: Simplificado, Intermediário e Avançado. No entanto, para que esses índices possam ser utilizados, é necessária a obtenção numérica dos valores dos mesmos. Para os índices absolutos, 
obtêm-se valores de vazão, em m³/h; para os índices relativos, valores percentuais, variando de 0 a 1 , ou de 0 a $100 \%$.

Para alcançar o resultado numérico desses índices, é necessário, inicialmente, que se tenha os dados de oferta em determinado trecho de rio ou reservatório, referentes à vazão de referência ( $Q_{\text {referencia }}$ ), em 1/s. Além deste, são requeridos os dados de demanda, que consistem nas vazões de outorga dos pontos de interferência localizados num trecho de rio (ou reservatório) determinado, somados às Demandas Bioquímicas de Oxigênio $\mathrm{DBO}_{5,20}$ do efluente, no caso dos pontos de lançamento, para cálculo das vazões de demanda $\left(\mathrm{Q}_{\text {demanda }}\right)$ de cada um dos pontos, em 1/s. Por conseguinte, é também exigido o somatório das vazões de demanda dos trechos de montante $\left(\Sigma \mathrm{Q}_{\text {montante }}\right)$.

De posse desses dados, definem-se Indicadores Gerais para encontrar valores numéricos para os índices absolutos (QAB1 e QAB2) e para os índices relativos (PCC, P1CI1, P1CI2, P2CI1 e P2CI2). Com a determinação dos índices, uma vazão outorgada pode ser classificada no nível 1 - Monitoramento Simplificado, nível 2 - Monitoramento Intermediário ou nível 3 Monitoramento Avançado.

Várias formas podem ser utilizadas para criação desses indicadores. Uma vez que a organização espacial adotada para o presente trabalho se dá para cada trecho i, onde se possui dados das vazões outorgadas, optou-se por criar indicadores gerais que relacionem duas variáveis: os valores das vazões de demanda $\mathrm{Q}_{\text {demanda }}$ outorgadas em i, bem como o quantitativo $\mathrm{N}$ de vazões outorgadas no referido trecho, sendo que cada vazão outorgada corresponde a um ponto de interferência, podendo ser de captação ou lançamento.

Antes da apresentação dos indicadores, utilizando o conceito de vazão de demanda ( $\left.Q_{\text {demanda }}\right)$ e o número de pontos de interferência $\mathrm{N}$ relacionados às vazões outorgadas, bem como os três níveis de controle de monitoramento definidos para classificação das vazões (Nível 1 Monitoramento Simplificado, 2 - Intermediário e 3 - Avançado), elencam-se as seguintes variáveis:

$\Sigma Q_{\text {dem }} \mathbf{T}(\mathbf{i})$ - somatório de todas as vazões de demanda outorgadas num trecho i;

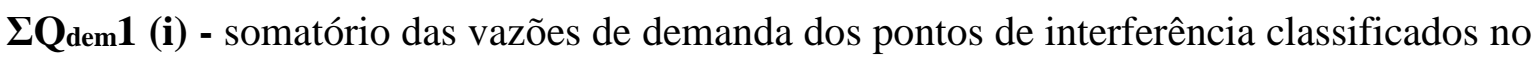
$1^{\circ}$ estágio (monitoramento simplificado); 
$\Sigma Q_{\text {dem2 }}$ (i) - somatório das vazões de demanda dos pontos de interferência classificados no $2^{\circ}$ estágio (monitoramento intermediário);

$\boldsymbol{\Sigma} \mathbf{Q}_{\text {dem3 }} \mathbf{3}$ (i) - somatório das vazões de demanda dos pontos de interferência classificados no $3^{\circ}$ estágio (monitoramento avançado);

NT (i) - número total de pontos relacionados às vazões outorgadas num trecho i;

N1 (i) - número de vazões classificadas no $1^{\text {o }}$ estágio (Monit. Simplificado);

N2 (i) - número de vazões classificadas no $2^{\circ}$ estágio (Monit. Intermediário);

N3 (i) - número de vazões classificadas no $3^{\circ}$ estágio (Monit. Avançado).

Sabendo que: $\Sigma Q_{\operatorname{dem}} 1$ (i) $+\Sigma Q_{\operatorname{dem}} 2$ (i) $\Sigma Q_{\operatorname{dem}} 3$ (i) $=\Sigma Q_{\operatorname{dem}} \mathrm{T}$ (i)

$$
\mathrm{N} 1(\mathrm{i})+\mathrm{N} 2(\mathrm{i})+\mathrm{N} 3(\mathrm{i})=\mathrm{NT}(\mathrm{i})
$$

Traça-se, com a criação dos indicadores, um caminho reverso do fluxograma apresentado na Figura 4.2. Naquele fluxograma, a partir dos dados dos usuários de um determinado trecho de rio e dos índices absolutos e relativos, chega-se à classificação das vazões outorgadas em um dos três estágios de monitoramento. Como ainda não se tem os valores numéricos dos índices, a partir de dados concretos de oferta e demanda de determinado trecho, bem como dos Indicadores Gerais apresentados a seguir, possibilita-se encontrar esses valores para os índices absolutos e relativos.

\section{$\underline{1^{\circ} \text { Indicador - Controle objetivo do monitoramento }}$}

A ideia central desse indicador é que o órgão gestor de recursos hídricos tenha uma maximização do controle dos volumes reais utilizados, frente ao volume total outorgado aos usuários de recursos hídricos de uma determinada bacia.

Dos três estágios de classificação estipulados, observa-se que os usuários outorgados que estiverem no $1^{\circ}$ estágio não serão exigidos um controle objetivo da vazão e da $\mathrm{DBO}_{5,20}$ (lançamento), pois poderão informar somente os valores de projeto, uma vez que serão aceitos somente os valores declarados numa planilha.

Já os usuários pertencentes ao $2^{\circ}$ estágio possuirão um controle objetivo do tempo de uso, pela exigência de instalação de horímetro ou similar, bem como da vazão e da $\mathrm{DBO}_{5,20}$, pela medição desses parâmetros pelo menos uma vez por ano. 
Os usuários do $3^{\circ}$ estágio já possuem um controle ainda maior, por instalarem equipamentos que meçam a vazão de forma instantânea e que totalizem o tempo. Em termos qualitativos, deverão realizar medições mensais de $\mathrm{DBO}_{5,20}$. Além disso, os usuários ainda serão obrigados a enviar ao órgão gestor o volume total utilizado.

Uma vez que os usuários a serem classificados nos estágios 2 e 3 deverão ter um monitoramento objetivo do uso outorgado, tomando então as vazões de demanda dos pontos de interferência classificados nesses dois estágios, $\Sigma Q_{\operatorname{dem}} 2$ (i) e $\Sigma Q_{\operatorname{dem}} 3$ (i), deve-se buscar, com esse $1^{\circ}$ indicador geral, que o somatório das vazões classificadas nesses estágios 2 e 3 tenham um percentual significativo em relação ao total podendo ser, por exemplo, maior ou igual a $80 \%$ da vazão de demanda total outorgada na bacia. Assim:

$$
\Sigma \mathrm{Q}_{\operatorname{dem}} 2(\mathrm{i})+\Sigma \mathrm{Q}_{\operatorname{dem}} 3(\mathrm{i}) \geq 0,8 \times \Sigma \mathrm{Q}_{\operatorname{dem}} \mathrm{T}(\mathrm{i})
$$

\section{$\underline{2^{\circ} \text { Indicador - Verificacão do real uso outorgado }}$}

Para esse indicador, busca-se que tenha uma maximização da verificação, por parte do órgão gestor de recursos hídricos, do real uso por ele outorgado.

A verificação parte do pressuposto que o órgão gestor tenha em mãos os dados reais da vazão de demanda dos pontos de interferência. Uma vez que esses dados dos volumes reais utilizados são exigidos aos usuários pertencentes ao $3^{\circ}$ estágio (monitoramento avançado), então deve-se buscar, para este indicador, que o somatório das vazões de demanda dos pontos de interferência classificados no $3^{\circ}$ estágio $(\mathrm{Q} 3)$ tenham um percentual mínimo em relação à vazão de demanda total outorgada num determinado trecho de rio. Pode-se ensejar, por exemplo, que as vazões outorgadas e classificadas no $3^{\circ}$ nível representem pelo menos 405 do total outorgado no trecho. Tem-se, dessa forma:

$$
\Sigma \mathrm{Q}_{\mathrm{dem}} 3(\mathrm{i}) \geq 0,4 \times \Sigma \mathrm{Q}_{\mathrm{dem}} \mathrm{T}(\mathrm{i})
$$

\section{$\underline{3^{\circ} \text { Indicador - Otimização do trabalho de fiscalização }}$}


Conforme visto anteriormente, aos usuários do $3^{\circ}$ estágio exige-se a aquisição e instalação correta de um medidor de vazão, a coleta e análise mensal da Demanda Bioquímica de Oxigênio (quando o ponto de interferência for de lançamento), e o envio desses dados reais utilizados ao órgão outorgante.

No trabalho de fiscalização do uso de recursos hídricos, deve-se atentar para o fato de que, uma vez imposta uma norma de instalação de equipamento de vazão e exigida aos usuários o envio dos dados medidos, então esses dados devem passar por uma análise por parte do órgão gestor, senão não há o porquê de se onerar os outorgados para obtenção e envio dessas informações.

Face à série de atividades envolvidas em torno de exigências aos usuários pertencentes ao $3^{\circ}$ estágio, este indicador busca minimizar o número de usuários classificados nesse estágio. Explicitando melhor, este indicador objetiva que o número de usuários classificados no $3^{\circ}$ estágio seja limitado a um número máximo de usuários, para evitar uma quantidade excessiva de atividades fiscalizatórias para o órgão gestor de recursos hídricos outorgante.

Esse indicador representa, de uma forma geral, uma realidade observada nas outorgas de direito de uso de recursos hídricos emitidas pelos órgãos gestores: uma parcela menor de usuários (entre 5 e 15\%) é responsável pela maioria do volume outorgado nas bacias (entre 70 e 90\%). Como exemplos, pode-se citar a calha do rio Paraíba do Sul, onde 80 dos 729 usuários (11\%) possuem 86\% do volume outorgado, de acordo com Barcellos et al. (2011); na bacia do rio Doce, $75 \%$ do total outorgado foi concedido a $12 \%$ dos usuários (Dalfior\&Sado, 2013); na bacia do rio São Francisco, Vera (2014) verificou que 10\% dos usuários são responsáveis por $96 \%$ do volume outorgado na bacia.

Deve-se buscar, portanto, com este indicador, que o número de vazões classificadas no $3^{\circ}$ estágio - N3 (i) - tenha um percentual menor em relação número total de vazões outorgadas - NT (i). Pode-se estipular, por exemplo, um valor de até $10 \%$ do total. Além disso, levando em conta os outros 2 indicadores anteriormente apresentados, que essa parcela menor de usuários outorgados num trecho, tenham uma representatividade significativa em termos de volume outorgado. Assim:

$$
\mathrm{N} 3(\mathrm{i}) \leq 0,10 \times \mathrm{NT} \text { (i) }
$$




\subsubsection{Classificação final dos pontos de interferência}

Os três níveis de exigência criados (Monitoramento Simplificado, Intermediário e Avançado) para o controle dos usos outorgados num determinado rio, trecho de rio ou reservatório servem como classificação final das vazões outorgadas.

De acordo com os parâmetros outorgados, calcula-se a vazão de demanda do ponto $Q_{\text {demanda }}$

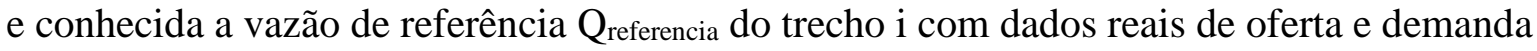
da bacia do rio São Francisco, como estudo de caso a ser apresentado no capítulo seguinte.

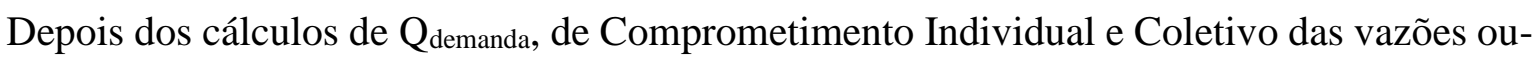
torgadas no estudo de caso, e levando em conta os valores iniciais estabelecidos para os índices absolutos (QAB1 e QAB2) e índices relativos (PCC, P1CI1, P1CI2, P2CI1 e P2CI2), vistos no item 4.6, verifica-se de uma maneira global, para todos os trechos da bacia objeto do estudo de caso, se as vazões outorgadas atendem aos três indicadores gerais:

$\underline{1^{\mathrm{o}} \text { Indicador - Controle objetivo do monitoramento: }} \Sigma \mathrm{Q}_{\mathrm{dem}} 2(\mathrm{i})+\Sigma \mathrm{Q}_{\mathrm{dem}} 3(\mathrm{i}) \geq 0,8 \times \Sigma \mathrm{Q}_{\mathrm{dem}} \mathrm{T}(\mathrm{i})$ $\underline{2^{\circ} \text { Indicador - Verificação do real uso outorgado: }} \Sigma \mathrm{Q}_{\operatorname{dem}} 3$ (i) $\geq 0,4 \times \Sigma \mathrm{Q}_{\operatorname{dem}} \mathrm{T}$ (i)



Cabe aqui explicar que os índices absolutos independem do trecho onde está localizado. Eles simplesmente classificam uma diretamente uma vazão outorgada em termos de mínimo e máximo: quando $\mathrm{Q}_{\text {demanda }}<\mathrm{QAB} 1 \rightarrow 1^{\circ}$ Estágio (Monitoramento Simplificado) e $\mathrm{Q}_{\text {demanda }}$ $\geq$ QAB3 $\rightarrow 3^{\circ}$ Estágio (Monitoramento avançado).

\subsection{ESTUDO DE CASO: A BACIA DO SÃO FRANCISCO}

Para controle e monitoramento de pontos de interferência outorgados, verifica-se a necessidade de determinação dos valores numéricos dos índices absolutos e relativos, definidos para classificação desses pontos num dos três estágios gradativos de monitoramento: Simplificado, Intermediário e Avançado. 
A fim de se alcançar este objetivo, faz-se necessária a escolha de dados reais de usuários outorgados, como estudo de caso. Obteve-se então junto à Agência Nacional de Águas dados reais de usuários outorgados por aquela Agência, divididos em 27 trechos de rio e reservatórios de domínio da União, com condições de oferta definidas pela vazão de referência Q95 (vazão com garantia de 95\% de permanência dentro da série histórica de dados observada), sistema este adotado pela ANA. Todos os trechos estão localizados na bacia do rio São Francisco, contemplando 1760 pontos de interferência outorgados, com os dados de outorga atualizados em novembro de 2015.

A bacia do rio São Francisco é subdividida em quatro sub-bacias, compreendendo o Alto São Francisco, Médio São Francisco, Submédio São Francisco e Baixo São Francisco. Essa divisão foi elaborada pelos desníveis dos terrenos que direcionam a água das áreas mais altas para as mais baixas. A seguir, apresenta-se uma figura com os corpos hídricos de domínio da União pertencentes à bacia do São Francisco, bem como as sub-bacias:

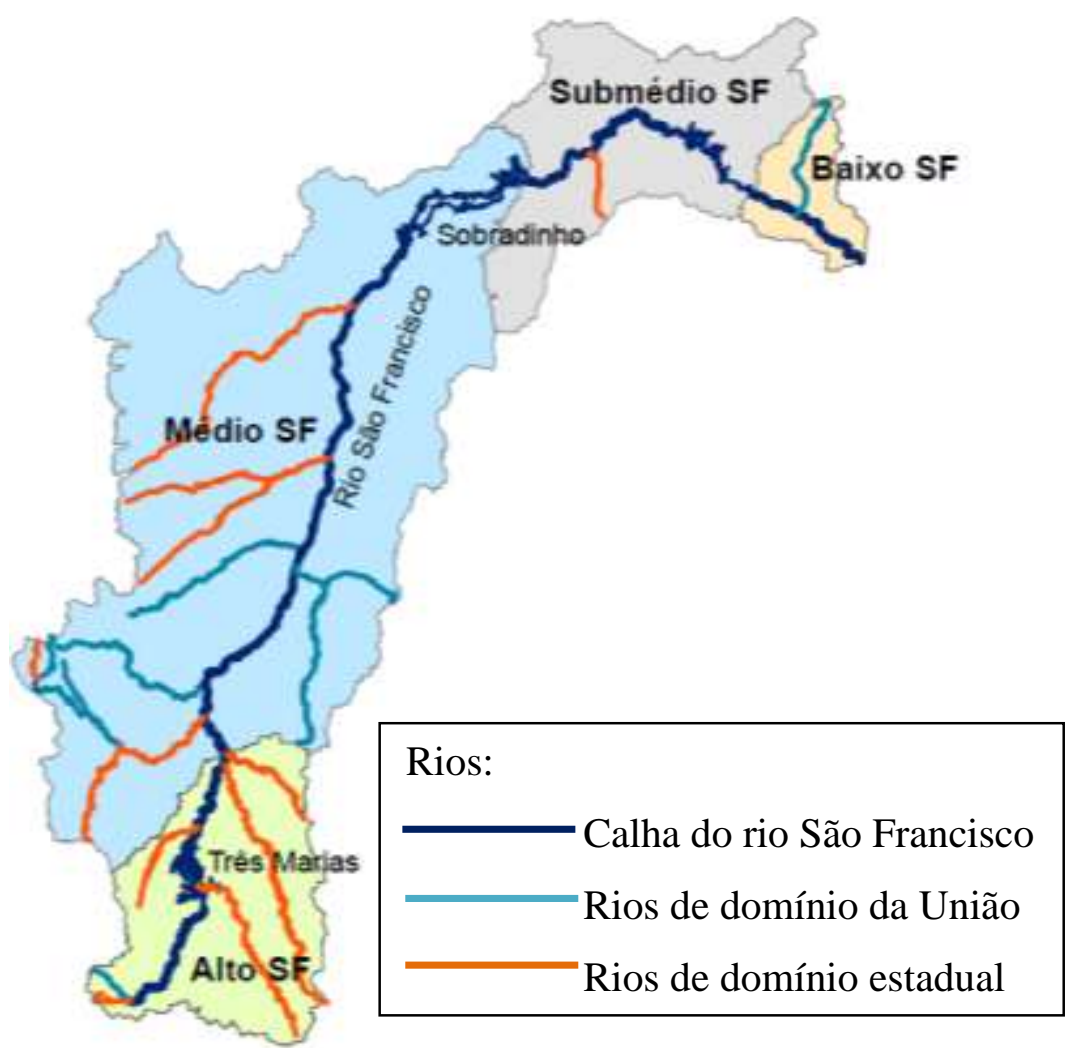

Figura 5.2 - Bacia do São Francisco com as sub-bacias e os corpos de água

A bacia do São Francisco foi escolhida para este trabalho, tendo em vista sua representatividade em diversos aspectos, elencados a seguir: 
- Quanto ao porte dos rios e reservatórios: dos 27 trechos objetos do estudo de caso para a bacia do SF, 9 são referentes aos rios Bezerra, Preto, Urucuia, Carinhanha, Verde Grande e Verde Pequeno e o reservatório de UHE Queimado, com vazão de referência menor que 50.000 1/s. Em contrapartida, os outros 18 trechos possuem vazões de referência superiores a 150.000 l/s, sendo 13 destes constituintes da calha do rio São Francisco, e mais 5 reservatórios, a saber: Três Marias, Sobradinho, Itaparica, Moxotó/Paulo Afonso e Xingó;

- Quanto à variabilidade dos pontos de interferência: dos 1760 pontos de interferência outorgados nos 27 trechos de domínio da União, 1691 são pontos de captação e 69 são pontos de lançamento, com vazões individuais que variam desde 4 1/s, vazão mínima outorgável na bacia, definida pelo Comitê do São Francisco mediante Resolução CNRH n 113, de 10 de junho de 2010 (Brasil, 2010a) até 60.000 1/s, que corresponde à outorga emitida pela ANA para a Codevasf, pelo uso de recursos hídricos referente ao projeto Baixio de Irecê;

- Quanto à disponibilidade hídrica dos trechos: os trechos escolhidos apresentam uma variação desde $2 \%$ de comprometimento hídrico até $145 \%$. Vale comentar que os trechos com mais de 100\% de comprometimento na bacia do São Francisco compreendem os rios Verde Pequeno e Verde Grande. Nesses corpos hídricos, apesar de existir comprometimento coletivo superior a 100\%, a ANA outorga sob condições especiais, com alocação negociada de água e restrições de uso em períodos de estiagem.

\subsubsection{Obtenção dos dados}

Em primeiro, para definição da disponibilidade hídrica de cada um dos 27 trechos objetos de estudo do estudo de caso, foram obtidas junto à ANA as vazões de referência ( $Q_{\text {referencia }}$ ) por meio de utilização do SCBH da bacia do São Francisco, desenvolvido por Collischonn (2014). Vale comentar que esses dados do SCBH são os adotados pela Agência para verificação da disponibilidade hídrica nas principais bacias cuja outorga é de sua responsabilidade, inclusive a do São Francisco. 
De acordo com a Resolução ANA n ${ }^{\circ}$ 1041, de 19 de agosto de 2013, as vazões de referência adotadas para os corpos de água de domínio da União são definidas para três situações (Brasil, 2013):

- Em trechos de rios em condições naturais: vazão natural com alta permanência no tempo (Q95), obtida de regionalização ou a partir de estações de monitoramento próximas;

- Dentro de reservatórios: Q95 do rio no local do barramento, quando o reservatório pertence ao Sistema Integrado Nacional (SIN) ou vazão regularizada, em outros reservatórios;

- A jusante de reservatórios de regularização: vazão mínima do reservatório logo a montante, acrescida da $\mathrm{Q}_{95}$ do trecho incremental.

Cabe aqui informar que a ANA disponibiliza, para algumas bacias e reservatórios, via web (http://scbh.ana.gov.br/), o acesso ao sistema de balanço hídrico adotado por ela, de tal forma que qualquer usuário pode entrar e verificar, informando dados quantitativos e qualitativos, se há disponibilidade de água no trecho escolhido. Entretanto, para a bacia do São Francisco, ainda não há essa disponibilização.

Os dados de disponibilidade hídrica dos trechos, ou seja, as vazões de referência ( $Q_{\text {referencia }}$ ) foram obtidas com acesso de login e senha de usuário interno da Agência (órgão gestor). A numeração dos trechos foi escolhida de montante para jusante na bacia, por questões de organização de trabalho, a fim de localizar os pontos de interferência com vazões outorgadas por meio do programa Arc Gis.

Além das vazões de referência ( $\mathrm{Q}_{\text {referencia }}$ ), para cada trecho foram obtidos pelo SCBH as vazões outorgadas nos trechos de montante ou anteriores ( $\left.\Sigma Q_{\text {montante }}\right)$, uma vez que o referido SSD utiliza esses dados para cálculo dos indicadores de comprometimento coletivo (ICC).

Apresentam-se, a seguir, tabelas com os dados dos trechos objetos de estudo, contendo para cada um dos mesmos: localização (rio ou reservatório), as vazões outorgadas à montante ou nos trechos anteriores ( $\left.\Sigma Q_{\text {montante }}\right)$, vazão de referência ( $Q_{\text {referencia }}$ ), e o número dos pontos de interferência outorgados que se localizam no referido trecho.

Tabela 5.3- trechos da sub-bacia do Alto São Francisco (Estado de Minas Gerais) 


\begin{tabular}{|r|c|l|r|r|r|}
\hline $\begin{array}{c}\mathbf{N}^{\mathbf{0}} \\
\text { Trecho }\end{array}$ & Sub-bacia & \multicolumn{1}{|c|}{ Localização } & $\begin{array}{c}\mathbf{\Sigma} \text { Qmontante } \\
(\mathbf{l} / \mathbf{s})\end{array}$ & $\begin{array}{c}\mathbf{Q}_{\text {referencia }} \\
(\mathbf{l} / \mathbf{s})\end{array}$ & $\begin{array}{c}\mathbf{N}^{\mathbf{0}} \text { ptos de } \\
\text { interferência }\end{array}$ \\
\hline 1 & $\begin{array}{c}\text { Alto SF } \\
\text { (MG) }\end{array}$ & $\begin{array}{l}\text { Rio São Francisco, da confluência com o } \\
\text { rio Samburá até o Res. 3 Marias }\end{array}$ & 2.511 & 21.641 & 29 \\
\hline 2 & $\begin{array}{c}\text { Alto SF } \\
(\mathrm{MG})\end{array}$ & $\begin{array}{l}\text { Reservatório de Três Marias, formado } \\
\text { pelo barramento do rio São Francisco }\end{array}$ & 6.552 & 155.000 & 57 \\
\hline 3 & $\begin{array}{c}\text { Alto SF } \\
\text { (MG) }\end{array}$ & $\begin{array}{l}\text { Rio São Francisco, de jusante do Reserva- } \\
\text { tório de Três Marias até a confluência com } \\
\text { o rio das Velhas }\end{array}$ & 8.578 & 350.100 & 53 \\
\hline
\end{tabular}

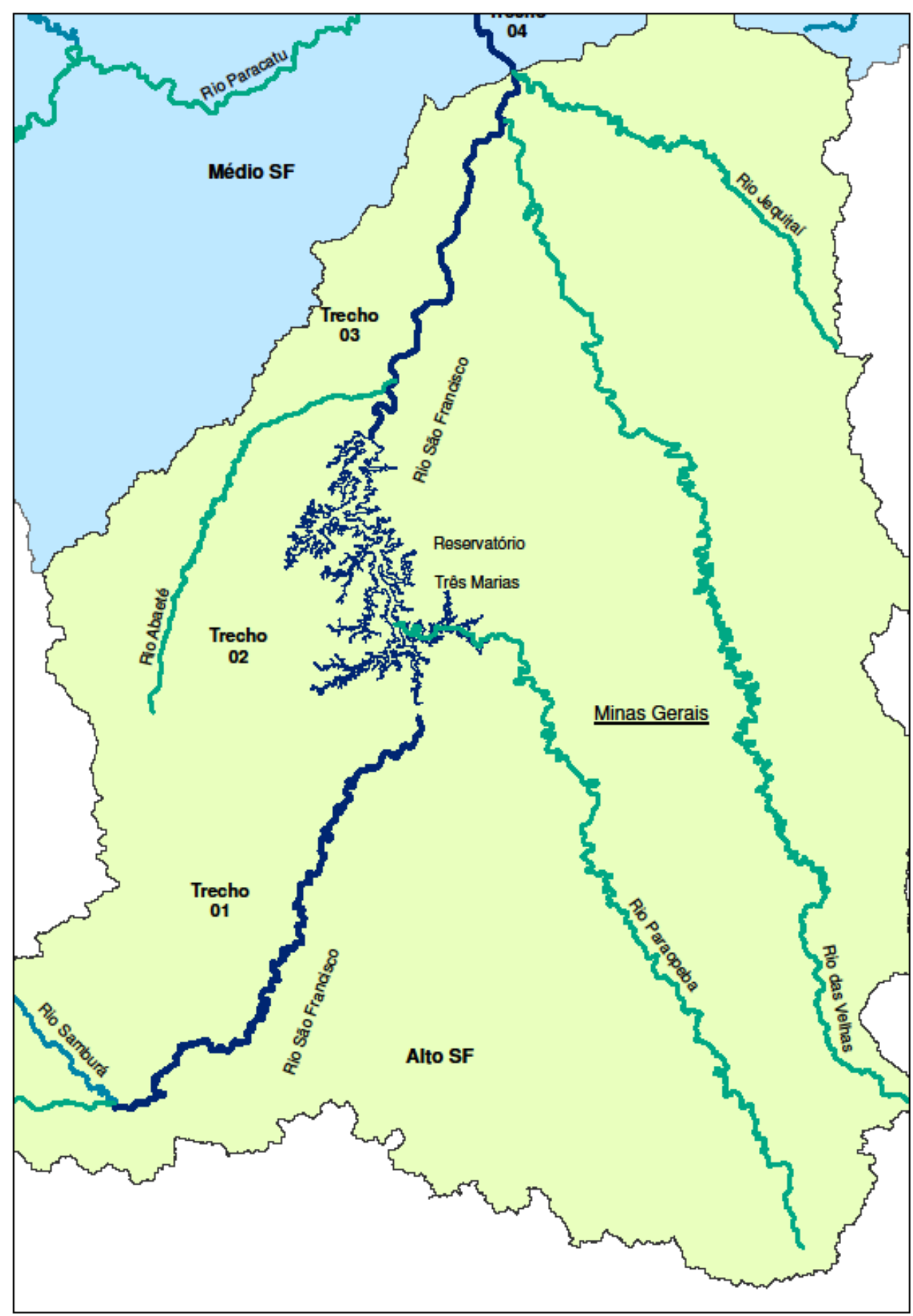

Figura 5.3- Representação dos trechos 1 a 3 (em azul escuro), localizados na sub-bacia do Alto São Francisco, Estado de Minas Gerais (Alto SF destacada em Verde Claro)

Tabela 5.4- trechos da sub-bacia do Médio São Francisco 


\begin{tabular}{|c|c|c|c|c|c|}
\hline $\begin{array}{c}\mathbf{N}^{\circ} \\
\text { Trecho }\end{array}$ & Sub-bacia & Localização & \begin{tabular}{|c|}
$\Sigma Q_{\text {montante }}$ \\
$(\mathbf{l} / \mathbf{s})$
\end{tabular} & \begin{tabular}{|c|}
$\begin{array}{c}Q_{\text {referencia }} \\
(\mathbf{l} / \mathbf{s})\end{array}$ \\
\end{tabular} & $\begin{array}{r}\mathrm{N}^{\mathrm{o}} \text { ptos de } \\
\text { nterferência }\end{array}$ \\
\hline 4 & $\begin{array}{l}\text { Médio SF } \\
\text { (MG) }\end{array}$ & $\begin{array}{l}\text { Rio São Francisco, da confluência com rio } \\
\text { das Velhas (divisa Alto/Médio SF) até a } \\
\text { confluência com o rio Paracatu }\end{array}$ & 35.451 & 396.100 & 11 \\
\hline 5 & $\begin{array}{l}\text { Médio SF } \\
(\mathrm{DF} / \mathrm{GO})\end{array}$ & $\begin{array}{l}\text { Rio Bezerra, da nascente até foz (deságue } \\
\text { no rio Preto) }\end{array}$ & 203 & 4.000 & 23 \\
\hline 6 & $\begin{array}{c}\text { Médio SF } \\
(\mathrm{DF} / \mathrm{GO} / \mathrm{MG})\end{array}$ & $\begin{array}{l}\text { Reservatório de UHE Queimado, formado } \\
\text { pelo barramento do rio Preto }\end{array}$ & 323 & 20.000 & 43 \\
\hline 7 & $\begin{array}{l}\text { Médio SF } \\
\text { (GO/MG) }\end{array}$ & $\begin{array}{l}\text { Rio Preto, de jusante do reservatório UHE } \\
\text { Queimado até a confluência com o Ribeirão } \\
\text { Roncador }\end{array}$ & 4.320 & 11.225 & 38 \\
\hline 8 & $\begin{array}{l}\text { Médio SF } \\
\text { (GO/MG) }\end{array}$ & $\begin{array}{l}\text { Rio Preto, da confluência com Ribeirão } \\
\text { Roncador até a foz (deságua no Rio Para- } \\
\text { catu) }\end{array}$ & 4.482 & 18.600 & 42 \\
\hline 9 & $\begin{array}{l}\text { Médio SF } \\
\text { (MG) }\end{array}$ & $\begin{array}{l}\text { Rio São Francisco, da confluência com rio } \\
\text { Paracatu até a confluência com rio Urucuia }\end{array}$ & 73.591 & 451.200 & 10 \\
\hline 10 & $\begin{array}{l}\text { Médio SF } \\
\text { (GO/MG) }\end{array}$ & $\begin{array}{l}\text { Rio Urucuia, da nascente até a foz (deságue } \\
\text { no Rio São Francisco) }\end{array}$ & 132 & 26.400 & 54 \\
\hline 11 & $\begin{array}{l}\text { Médio SF } \\
\quad(\mathrm{MG})\end{array}$ & $\begin{array}{l}\text { Rio São Francisco, da confluência com o rio } \\
\text { Urucuia até a confluência com o rio Verde } \\
\text { Grande }\end{array}$ & 91.757 & 478.900 & 60 \\
\hline 12 & $\begin{array}{l}\text { Médio SF } \\
\text { (MG/BA) }\end{array}$ & $\begin{array}{l}\text { Rio Verde Grande, da nascente até a foz } \\
\text { (deságue no Rio São Francisco) }\end{array}$ & 323 & 3.300 & 131 \\
\hline 13 & $\begin{array}{l}\text { Médio SF } \\
\text { (MG/BA) }\end{array}$ & $\begin{array}{l}\text { Rio Verde Pequeno, da nascente até a foz } \\
\text { (deságue no Rio Verde Grande) }\end{array}$ & 78 & 800 & 45 \\
\hline 14 & $\begin{array}{l}\text { Médio SF } \\
\text { (MG/BA) }\end{array}$ & $\begin{array}{l}\text { Rio São Francisco, da confluência com o rio } \\
\text { Verde Grande até a confluência com o rio } \\
\text { Carinhanha }\end{array}$ & 218.323 & 530.650 & 13 \\
\hline 15 & $\begin{array}{l}\text { Médio SF } \\
\text { (MG/BA) }\end{array}$ & $\begin{array}{l}\text { Rio Carinhanha, da nascente até a foz (desá- } \\
\text { gue no Rio São Francisco) }\end{array}$ & 601 & 31.800 & 27 \\
\hline 16 & $\begin{array}{l}\text { Médio SF } \\
\quad \text { (BA) }\end{array}$ & $\begin{array}{l}\text { Rio São Francisco, da confluência com o rio } \\
\text { Carinhanha até a confluência com o rio Cor- } \\
\text { rente }\end{array}$ & 235.525 & 550.100 & 22 \\
\hline 17 & $\begin{array}{l}\text { Médio SF } \\
\text { (BA) }\end{array}$ & $\begin{array}{l}\text { Rio São Francisco, da confluência com o rio } \\
\text { Corrente até confluência com o rio Alegre }\end{array}$ & 274.553 & 595.553 & 23 \\
\hline 18 & $\begin{array}{l}\text { Médio SF } \\
\text { (BA) }\end{array}$ & $\begin{array}{l}\text { Rio São Francisco, da confluência com o rio } \\
\text { Alegre até a confluência com o rio Grande }\end{array}$ & 289.247 & 622.629 & 12 \\
\hline
\end{tabular}




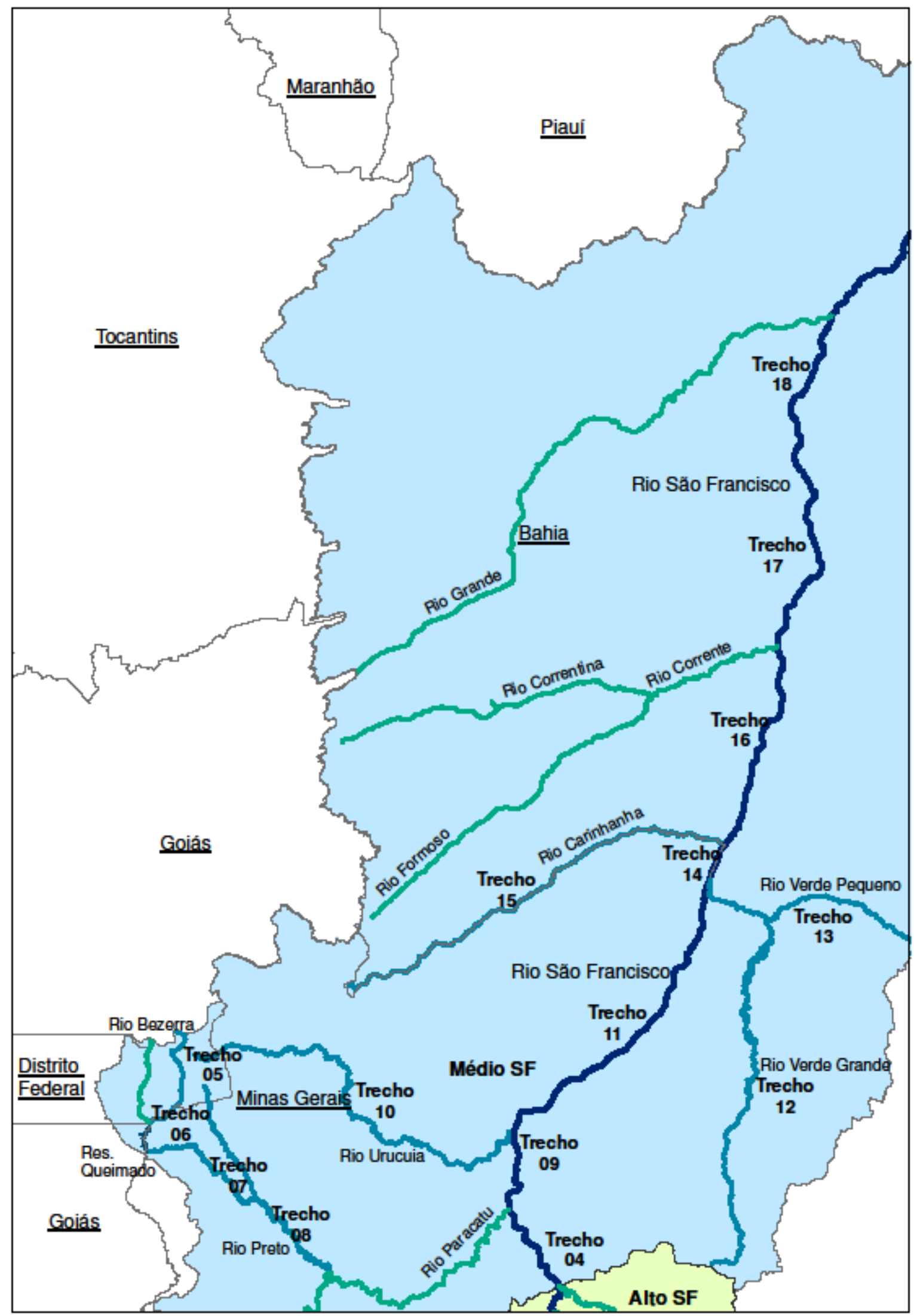

Figura 5.4 - Representação dos trechos 4 a 18 (em linhas cor azul claro e escuro), localizados na sub-bacia do Médio São Francisco (pintada em azul claro) 
Tabela 5.5- trechos da sub-bacia do Médio, Submédio e Baixo São Francisco

\begin{tabular}{|c|c|c|c|c|c|}
\hline $\begin{array}{c}\mathbf{N}^{\circ} \\
\text { Trecho }\end{array}$ & Sub-bacia & Localização & $\begin{array}{c}\Sigma Q_{\text {montante }} \\
(\mathbf{l} / \mathbf{s})\end{array}$ & $\begin{array}{c}Q_{\text {referencia }} \\
(\mathbf{l} / \mathbf{s})\end{array}$ & $\begin{array}{l}\mathbf{N}^{0} \text { ptos de } \\
\text { interferência }\end{array}$ \\
\hline 19 & $\begin{array}{l}\text { Médio SF } \\
\text { (BA) }\end{array}$ & $\begin{array}{l}\text { Rio São Francisco, da confluência com o rio } \\
\text { Grande até o reservatório de Sobradinho }\end{array}$ & 397.026 & 717.869 & 19 \\
\hline 20 & $\begin{array}{l}\text { Médio SF } \\
\text { (BA) }\end{array}$ & $\begin{array}{l}\text { Reservatório de Sobradinho, formado pelo } \\
\text { barramento do rio São Francisco }\end{array}$ & 430.075 & 758.934 & 185 \\
\hline 21 & $\begin{array}{l}\text { SubMédio SF } \\
\text { (BA/PE) }\end{array}$ & $\begin{array}{l}\text { Rio São Francisco, jusante do reserv. de So- } \\
\text { bradinho até confluência com rio Caraca }\end{array}$ & 430.460 & $800.000 *$ & 283 \\
\hline 22 & $\begin{array}{l}\text { SubMédio SF } \\
\text { (BA/PE) }\end{array}$ & $\begin{array}{l}\text { Rio São Francisco, da confluência com o rio } \\
\text { Caraca até o reservatório de Itaparica }\end{array}$ & 430.845 & $800.000 *$ & 114 \\
\hline 23 & $\begin{array}{l}\text { SubMédio SF } \\
\text { (BA/PE) }\end{array}$ & $\begin{array}{l}\text { Reservatório de Itaparica, formado pelo bar- } \\
\text { ramento do rio São Francisco }\end{array}$ & 494.415 & $800.000^{*}$ & 345 \\
\hline 24 & $\begin{array}{l}\text { SubMédio SF } \\
\text { (BA/PE) }\end{array}$ & $\begin{array}{l}\text { Reservatórios de Moxotó e Paulo Afonso, } \\
\text { formados pelo barramento do rio SF }\end{array}$ & 501.545 & $800.000^{*}$ & 36 \\
\hline 25 & $\begin{array}{l}\text { SubMédio SF } \\
\text { (BA/AL/SE) }\end{array}$ & $\begin{array}{l}\text { Reservatório de Xingó, formado pelo barra- } \\
\text { mento do rio São Francisco }\end{array}$ & 503.195 & $800.000 *$ & 15 \\
\hline 26 & $\begin{array}{l}\text { Baixo SF } \\
\text { (AL/SE) }\end{array}$ & $\begin{array}{l}\text { Rio São Francisco, jusante do reservatório } \\
\text { de Xingó até confluência com o rio Ipanema }\end{array}$ & 505.615 & $800.000 *$ & 14 \\
\hline 27 & $\begin{array}{l}\text { Baixo SF } \\
\text { (AL/SE) }\end{array}$ & $\begin{array}{l}\text { Rio São Francisco, da confluência com o rio } \\
\text { Ipanema até a foz (mar) }\end{array}$ & 534.545 & $800.000^{*}$ & 56 \\
\hline
\end{tabular}

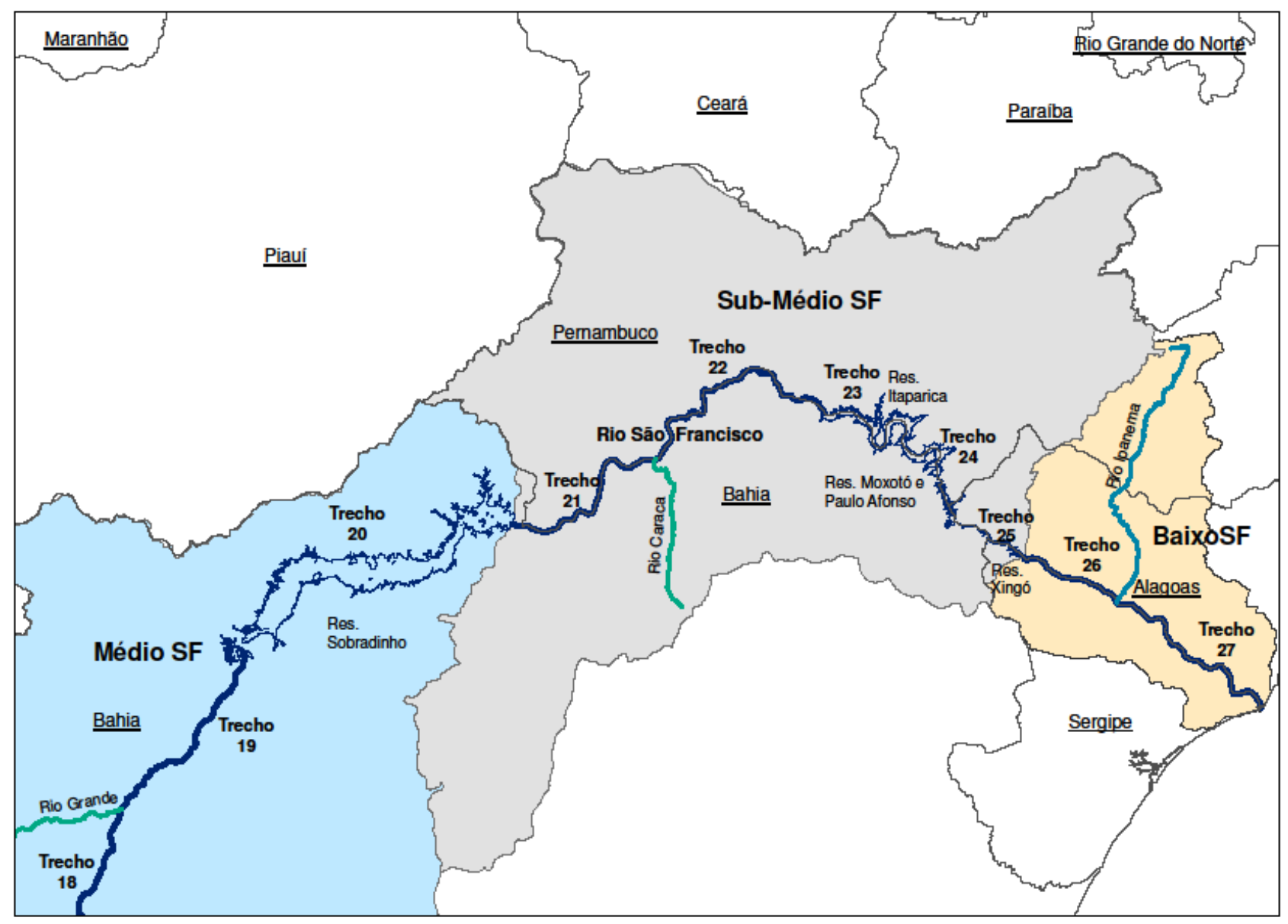

Figura 5.5 - Representação dos trechos 19 a 27 (em linhas cor azul escuro), localizados na sub-bacias do Médio (área em azul claro), Submédio (cinza) e Baixo São Francisco (amarelo) 
* A vazão de referência dos trechos finais do rio São Francisco, a partir do reservatório de Sobradinho, corresponde à descarga mínima instantânea autorizada pela ANA aos reservatórios a jusante do referido reservatório. A bacia do rio São Francisco vem enfrentando condições hidrológicas adversas desde 2013, com vazões e chuvas abaixo da média (ANA, 2016). De 2013 para cá, a ANA tem autorizado diminuição na vazão defluente, que estava inicialmente em $1.300 \mathrm{~m}^{3} / \mathrm{s}$ e diminuiu por último para $800 \mathrm{~m}^{3} / \mathrm{s}$, de acordo com a Resolução ANA n 1492, de 18 de dezembro de 2015 (Brasil, 2015).

Os dados dos usuários outorgados pela ANA são públicos e estão disponíveis na internet, pelo link: http://www2.ana.gov.br/Paginas/institucional/SobreaAna/uorgs/sof/geout.aspx. Para o presente trabalho, selecionou-se as outorgas emitidas até novembro de 2015, tendo sido identificados e selecionados 1561 usuários outorgados na bacia do rio São Francisco.

Em seguida, acessou-se o Cadastro Nacional de Usuários de Recursos Hídricos (http://cnarh.ana.gov.br/) para obter informações relativas aos pontos de interferência destes 1561 usuários outorgados, tendo sido identificados 1760 pontos de interferência outorgados nos 27 trechos na bacia do SF, todos de domínio da União. Lembrando que cada usuário pode ter mais de um ponto outorgado pela ANA.

De posse da localização do ponto, da vazão máxima instantânea de captação ou lançamento, e de qualidade de água (no caso, do parâmetro DBO) de cada um desses pontos de interferência, organizou-se os dados de demanda dos pontos de interferência outorgados em planilha do Excel.

Para cada ponto de interferência outorgado, foram obtidos os seguintes dados:

- Localização geográfica no trecho: com a definição dos 27 trechos da bacia do São Francisco, utilizou-se o Mapa de Outorgas de Direito de uso - ANA, contido no Sistema Nacional de Informações sobre Recursos Hídricos (www.snirh.gov.br), para verificar a localização de cada ponto de interferência outorgado pela ANA na bacia do São Francisco, conforme exemplificação dos trechos 20 e 21 apresentados na figura a seguir: 


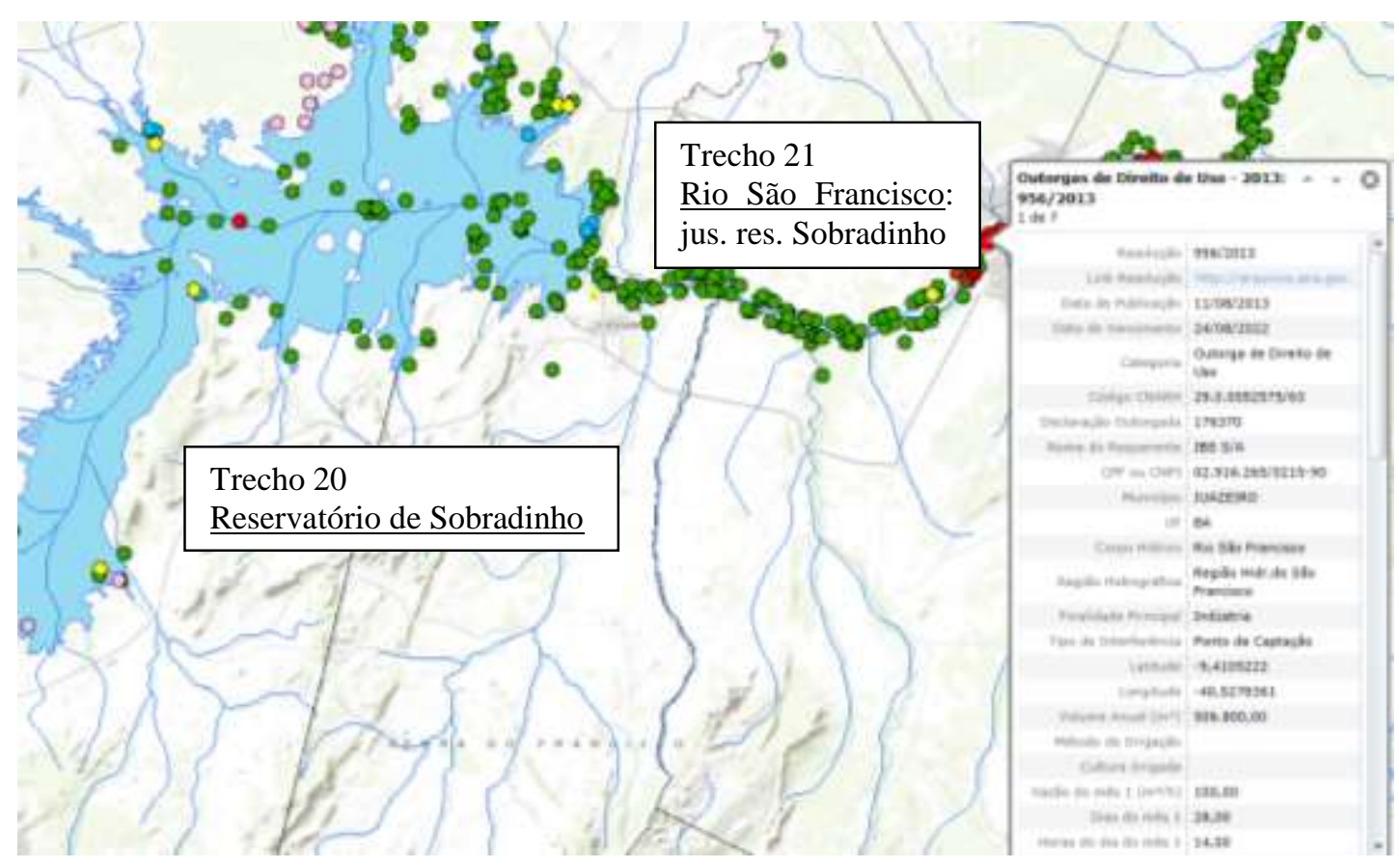

Figura 5.6 - Pontos de interferência outorgados pela ANA nos trechos 20 e 21, com destaque para os dados referentes à outorga de uso objeto da Resolução ANA 956/2013

- $\quad$ Vazão de captação: Sendo o ponto de interferência outorgado como captação, considerou-se $\mathbf{Q}_{\text {captação }}$ vazão máxima instantânea outorgada para a captação $\left(\mathrm{m}^{3} / \mathrm{h}\right)$, verificando no Cadastro Nacional de Usuários de Recursos Hídricos a capacidade instalada do usuário. Nota: a ANA outorga uma vazão média, de funcionamento, sendo que a capacidade instalada do funcionamento é maior ou igual à vazão média. Conforme pode ser observado na Figura abaixo, que corresponde aos dados da outorga do ponto de captação Eixo Norte da Transposição do São Francisco, a vazão média outorgada corresponde a $66408 \mathrm{~m}^{3} / \mathrm{h}$, sendo que a capacidade instalada, considerada como Qmáx_captação, é igual a 95040m³/h.

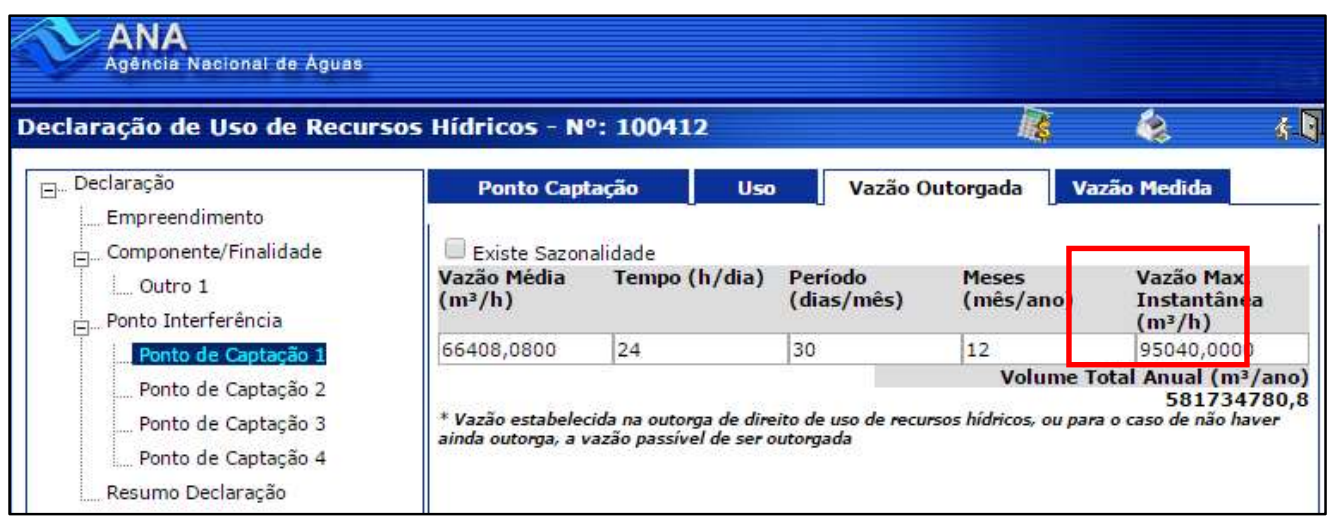

Figura 5.7 - Vazão máxima instantânea da declaração de uso constante no CNARH, como exemplificação de onde se extrai o Qcaptação 
- $\quad$ Demanda Bioquímica de Oxigênio do Efluente Tratado: para um ponto de interfe-

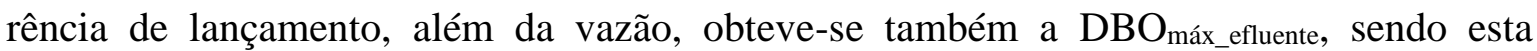
$\mathrm{DBO}_{5,20}$, ou seja, Demanda Bioquímica de Oxigênio, medida durante um período de 5 dias a uma temperatura de $20^{\circ} \mathrm{C}$, correspondendo à concentração máxima instantânea do efluente tratado, constante da declaração de uso no CNARH, outorgada pela ANA, em mg/l, conforme apresentada na figura abaixo:

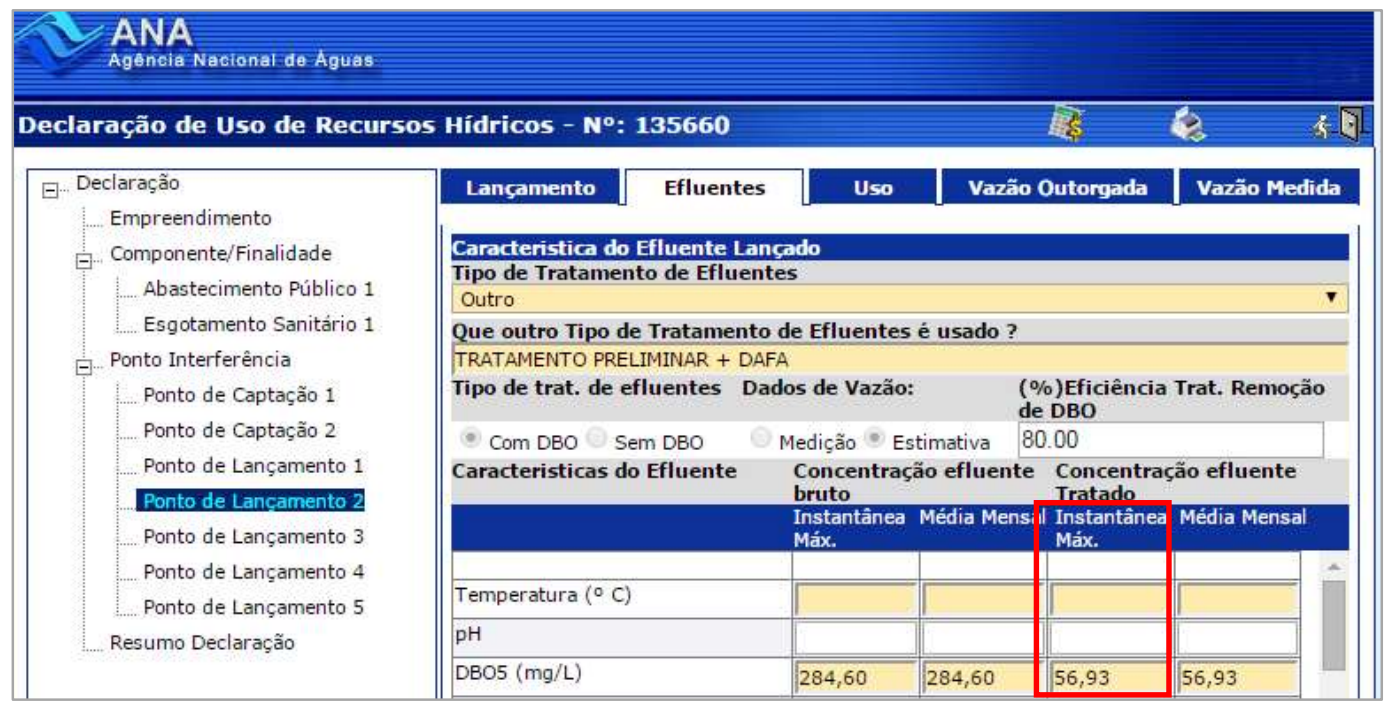

Figura 5.8 - Concentração máxima instantânea da DBO do efluente tratado, constante da declaração de uso no CNARH, como exemplificação de onde se extrai a $\mathrm{DBO}_{\text {efluente }}$

\subsubsection{Cálculos iniciais: Vazões de Demanda, Comprometimento Individual e Coletivo}

Vazão de Demanda: para cada vazão outorgada de captação, $\mathbf{Q}_{\text {demanda }}=\mathbf{Q}_{\text {máx-captação. }}$ Para as vazões de lançamento, calcula-se inicialmente a vazão de diluição. Assim:

$\mathrm{Q}_{\text {máx_diluição }}=\mathrm{Q}_{\text {máx_efluente }} \times \frac{\left(\mathrm{DBO}_{\text {máx_efluente }}-\mathrm{DBO}_{\text {permitida }}\right)}{\mathrm{DBO}_{\text {permitida }}-\mathrm{DBO}_{\text {natural }}}$, dado:

Qmáx-efluente = vazão máxima instantânea outorgada para o lançamento $\left(\mathrm{m}^{3} / \mathrm{h}\right)$, verificando no Cadastro Nacional de Usuários de Recursos Hídricos a capacidade instalada do usuário, conforme visto anteriormente.

$\mathbf{D B O}_{\text {permitida }}=\mathrm{DBO}_{5,20}$ permitida para o trecho, dada pelo seu enquadramento. Na bacia do São Francisco, o Comitê de Bacia Hidrográfica do São Francisco, por intermédio da Deliberação CBHSF N ${ }^{\circ}$ 12, de 30 de julho de 2004 (Brasil, 2004), adotou o valor de 5mg/l, correspondente à classe 2, como $\mathrm{DBO}_{5,20}$ permitida. Sendo assim, adotou-se a $\mathbf{D B O} \mathbf{O}_{\text {permitida }}=\mathbf{5}$ mg/l para o presente trabalho; 
DBOefluente = Concentração máxima instantânea do efluente tratado, constante da declaração de uso no CNARH e outorgada pela ANA, obtida conforme descrição anterior, em mg/l;

DBO $_{\text {natural }}=\mathrm{DBO}_{5,20}$ natural do trecho $(\mathrm{mg} / \mathrm{l})$. Conforme descrito no item 4.2, adotou-se a DBOnatural $=1 \mathrm{mg} / \mathbf{l}$ para o presente trabalho.

- $\quad$ Vazão indisponível: Somando a vazão máxima instantânea do efluente lançado com a vazão de diluição máxima instantânea, obteve-se a vazão indisponível máxima instantânea:

$$
\mathrm{Q}_{\text {máx_indisp. }}=\mathrm{Q}_{\text {máx_efluente }}+\mathrm{Q}_{\text {máx_diluição }}
$$

Qdemanda: finalizando a organização dos dados por ponto de interferência de captação ou lançamento, calculou-se $Q_{\text {demanda }}$ como sendo igual à Qmáx_captação, sendo o ponto outorgado de captação, ou à Qmáx_indisponível, sendo o ponto outorgado de lançamento. Assim:

$$
\mathrm{Q}_{\text {demanda }}=\mathrm{Q}_{\text {máx_captação }}\left(\text { captação) ou } \mathrm{Q}_{\text {demanda }}=\mathrm{Q}_{\text {máx_indisponível }}(\text { lançamento) }\right.
$$

Cabe relembrar que, para análise de outorga, a vazão outorgada para um ponto de interferência normalmente é representada pela vazão média de captação ou lançamento, podendo ser a média diária ou a média mensal. No entanto, como o presente trabalho leva em conta a necessidade de medição e cálculo da vazão de demanda $Q_{\text {demanda, }}$ considerou-se a capacidade máxima instalada no ponto de interferência, ou seja, a vazão máxima instantânea de captação ou de lançamento.

Comprometimento individual: para cada ponto de interferência, tendo sido calculado a $\mathrm{Q}_{\text {demanda }}$ e sabendo qual o trecho em que o referido ponto está localizado, ou seja, sabendo a vazão de referência Qreferencia do trecho, tem-se:

$$
\mathrm{ICI}_{\text {máx }}=\mathrm{ICI}_{\text {demanda }}=\frac{Q_{\text {demanda }}}{Q_{\text {referência (i) }}}
$$

Comprometimento coletivo: esse índice adimensional é calculado para cada trecho de rio e, para determinação do mesmo, deve-se achar considerar as vazões de demanda a montante, bem como as vazões de demanda no trecho.

Considerou-se as vazões de demanda a montante $\sum \mathrm{Q}_{\text {montante }}$ retiradas do $\mathrm{SCBH}$, apresentadas nas tabelas 5.1, 5.2 e 5.3 anteriores. Já as vazões de demanda para cada trecho i foram 
somadas, de forma a obter $\sum Q_{\text {demanda }}(i)$. Tem-se para cada trecho i, Indicador de Comprometimento Coletivo máximo como:

$$
\mathrm{ICC}_{\text {máx }}=\frac{\sum \mathrm{Q}_{\text {montante }}+\sum \mathrm{Q}_{\text {demanda }}(\mathrm{i})}{\mathrm{Q}_{\text {referência }}(\mathrm{i})}
$$

Para cada um dos 27 trechos da bacia do São Francisco, os dados foram organizados em planilha, sendo que as vazões outorgadas foram ordenadas de montante para jusante. Para classificação de cada ponto de interferência num dos três estágios gradativos de exigência quanto ao monitoramento: 1 - simplificado, 2 - intermediário ou 3 - avançado, foram adotados valores iniciais para os índices absolutos (QAB1, QAB2 e QAB3) e os índices relativos (PCC, P1CI1, P1CI2, P2CI1 e P2CI2). A escolha dos valores iniciais para os índices absolutos e relativos será relatada a seguir.

A classificação de cada uma das vazões outorgadas nos três níveis se deu em duas etapas:

- $\quad 1^{\circ}$ Etapa: classificação quanto aos índices absolutos: passou-se a uma comparação da vazão de demanda $Q_{\text {demanda }}$ do ponto de interferência em relação aos índices absolutos de mínimo e máximo, classificando-o diretamente no estágio 1 (monitoramento simplificado), se $\mathrm{Q}_{\text {demanda }}$ < índice mínimo (QAB1), ou no estágio 3 (avançado) se $\mathrm{Q}_{\text {de- }}$ manda > índice máximo (QAB2).

- $\quad \underline{2^{a}}$ Etapa: classificação quanto aos índices relativos: estando dentro do intervalo entre os mínimos e máximos absolutos, passou-se a verificação em termos relativos. Primeiro, de forma total no trecho, se o Indicador de Comprometimento Coletivo (IC$\mathrm{C}_{\text {máx }}$ ) é superior ou inferior ao índice PCC. Em seguida, classificando cada ponto de interferência num dos três estágios, pela comparação do Indicador de Comprometimento Individual ( ICI $_{\text {máx }}$ ) com os índices P1CI1, P1CI2, P2CI1 ou P2CI2.

Dessa forma, para cada trecho, foram dispostos na planilha os dados e os cálculos conforme apresentado na Tabela 5.4 a seguir, que demonstra os cálculos para realizados para o trecho 1 - nascente do Rio São Francisco, da confluência com o rio Samburá até o Reservatório de 3 Marias, levando em conta os valores iniciais dos índices absolutos e relativos estipulados na Metodologia. 
Tabela 5.6 - Classificação dos pontos de interferência do trecho 1 - nascente do Rio São Francisco, da confluência com o rio Samburá até o Reservatório de 3 Marias

\begin{tabular}{|c|c|c|c|c|c|c|c|c|c|c|c|c|}
\hline \multirow[b]{2}{*}{$\begin{array}{c}\text { Ponto de interferência ou- } \\
\text { torgado }\end{array}$} & \multirow[b]{2}{*}{\begin{tabular}{|c|} 
Qmáx_capt \\
$\left(\mathrm{m}^{3} / \mathbf{h}\right)$
\end{tabular}} & \multirow[b]{2}{*}{$\begin{array}{l}\text { Qmáx_efl } \\
\left(\mathbf{m}^{3} / \mathbf{h}\right)\end{array}$} & \multirow[b]{2}{*}{$\begin{array}{l}\mathrm{DBO}_{\text {efl }} \\
(\mathrm{mg} / \mathrm{L})\end{array}$} & \multirow[b]{2}{*}{$\begin{array}{c}\text { Qdemanda } \\
(1 / s)\end{array}$} & \multirow[b]{2}{*}{$\begin{array}{c}\Sigma Q_{\text {demanda }} \\
(\mathbf{l} / \mathbf{s})\end{array}$} & \multirow[b]{2}{*}{ ICI $_{\text {máx }}$} & \multirow[b]{2}{*}{ ICC $_{\text {máx }}$} & \multicolumn{2}{|c|}{ Índices Absolutos } & \multicolumn{2}{|c|}{ Índices Relativos } & \multirow{2}{*}{$\begin{array}{c}2^{\text {a }} \text { Etapa } \\
\text { Classif. final }\end{array}$} \\
\hline & & & & & & & & $\begin{array}{c}\text { Compara } \\
Q_{\text {demanda }}\end{array}$ & $\begin{array}{l}\text { Classif. } \\
1^{\text {a Etapa }}\end{array}$ & $\begin{array}{l}\text { Compara } \\
\text { ICC }_{\text {máx }}\end{array}$ & $\begin{array}{l}\text { Compara } \\
\text { ICI Íx }\end{array}$ & \\
\hline Clementino E. da Silva & 70,00 & & & 19,44 & 19,44 & $0,09 \%$ & $30,74 \%$ & $<500 \mathrm{~L} / \mathrm{s}$ & Verificar & $\mathrm{ICC}_{\text {máx }} \geq 30 \%$ & $\mathrm{ICI}_{\text {máx }}<0,1 \%$ & Simplificado \\
\hline Total Agroind. Canav-PI & 250,00 & & & 69,44 & 88,89 & $0,32 \%$ & $30,74 \%$ & $<500 \mathrm{~L} / \mathrm{s}$ & Verificar & $\mathrm{ICC}_{\text {máx }} \geq 30 \%$ & $\mathrm{ICI}_{\text {máx }}<0,5 \%$ & Intermediário \\
\hline Total Agroind. Canav-PII & 155,00 & & & 43,06 & 131,94 & $0,20 \%$ & $30,74 \%$ & $<500 \mathrm{~L} / \mathrm{s}$ & Verificar & $\mathrm{ICC}_{\text {máx }} \geq 30 \%$ & $\mathrm{ICI}_{\text {máx }}<0,5 \%$ & Intermediário \\
\hline Total Agroind. Canav-PIII & 300,00 & & & 83,33 & 215,28 & $0,39 \%$ & $30,74 \%$ & $<500 \mathrm{~L} / \mathrm{s}$ & Verificar & $\mathrm{ICC}_{\text {máx }} \geq 30 \%$ & $\mathrm{ICI}_{\text {máx }}<0,5 \%$ & Intermediário \\
\hline Central Energ. Cazanga & 700,00 & & & 194,44 & 409,72 & $0,90 \%$ & $30,74 \%$ & $<500 \mathrm{~L} / \mathrm{s}$ & Verificar & $\mathrm{ICC}_{\text {máx }} \geq 30 \%$ & $\mathrm{ICI}_{\text {máx }} \geq 0,5 \%$ & Avançado \\
\hline Placido Ribeiro Vaz & 204,00 & & & 56,67 & 466,39 & $0,26 \%$ & $30,74 \%$ & $<500 \mathrm{~L} / \mathrm{s}$ & Verificar & $\mathrm{ICC}_{\text {máx }} \geq 30 \%$ & $\mathrm{ICI}_{\text {máx }}<0,5 \%$ & Intermediário \\
\hline Iguatemi_Empreend. PI & 1536,30 & & & 426,75 & 893,14 & $1,97 \%$ & $30,74 \%$ & $<500 \mathrm{~L} / \mathrm{s}$ & Verificar & $\mathrm{ICC}_{\text {máx }} \geq 30 \%$ & $\mathrm{ICI}_{\text {máx }} \geq 0,5 \%$ & Avançado \\
\hline Iguatemi_Empreend. PII & 1536,30 & & & 426,75 & 1319,89 & $1,97 \%$ & $30,74 \%$ & $<500 \mathrm{~L} / \mathrm{s}$ & Verificar & $\mathrm{ICC}_{\text {máx }} \geq 30 \%$ & $\mathrm{ICI}_{\text {máx }} \geq 0,5 \%$ & Avançado \\
\hline Daniel Luiz Vieira & 28,80 & & & 8,00 & 1327,89 & $0,04 \%$ & $30,74 \%$ & $<10 \mathrm{~L} / \mathrm{s}$ & Simplificado & Simplificado & Simplificado & Simplificado \\
\hline White Martins Ltda - Lanç & & 1,00 & 57 & 3,89 & 1331,78 & $0,02 \%$ & $30,74 \%$ & $<10 \mathrm{~L} / \mathrm{s}$ & Simplificado & Simplificado & Simplificado & Simplificado \\
\hline White Martins Ltda - Capt & 130,00 & & & 36,11 & 1367,89 & $0,17 \%$ & $30,74 \%$ & $<500 \mathrm{~L} / \mathrm{s}$ & Verificar & $\mathrm{ICC}_{\text {máx }} \geq 30 \%$ & $\mathrm{ICI}_{\text {máx }}<0,5 \%$ & Intermediário \\
\hline BIOSEV_S.A. & 1800,00 & & & 500,00 & 1867,89 & $2,31 \%$ & $30,74 \%$ & $\geq 500 \mathrm{~L} / \mathrm{s}$ & Avançado & Avançado & Avançado & Avançado \\
\hline LDC Bioenergia S.A_PI & 1500,00 & & & 416,67 & 2284,56 & $1,93 \%$ & $30,74 \%$ & $<500 \mathrm{~L} / \mathrm{s}$ & Verificar & $\mathrm{ICC}_{\text {máx }} \geq 30 \%$ & $\mathrm{ICI}_{\text {máx }} \geq 0,5 \%$ & Avançado \\
\hline LDC Bioenergia S.A_PII & 600,00 & & & 166,67 & 2451,22 & $0,77 \%$ & $30,74 \%$ & $<500 \mathrm{~L} / \mathrm{s}$ & Verificar & $\mathrm{ICC}_{\text {máx }} \geq 30 \%$ & $\mathrm{ICI}_{\text {máx }} \geq 0,5 \%$ & Avançado \\
\hline LDC Bioenergia S.A_PIII & 600,00 & & & 166,67 & 2617,89 & $0,77 \%$ & $30,74 \%$ & $<500 \mathrm{~L} / \mathrm{s}$ & Verificar & $\mathrm{ICC}_{\text {máx }} \geq 30 \%$ & $\mathrm{ICI}_{\text {máx }} \geq 0,5 \%$ & Avançado \\
\hline LDC Bioenergia S.A_PIV & 1800,00 & & & 500,00 & 3117,89 & $2,31 \%$ & $30,74 \%$ & $\geq 500 \mathrm{~L} / \mathrm{s}$ & Verificar & Avançado & Avançado & Avançado \\
\hline Posto_Verde_Luzense & 155,00 & & & 43,06 & 3160,94 & $0,20 \%$ & $30,74 \%$ & $<500 \mathrm{~L} / \mathrm{s}$ & Verificar & $\mathrm{ICC}_{\text {máx }} \geq 30 \%$ & $\mathrm{ICI}_{\text {máx }}<0,5 \%$ & Intermediário \\
\hline Vantuil Antônio de Souza & 17,90 & & & 4,98 & 3165,94 & $0,02 \%$ & $30,74 \%$ & $<5 \mathrm{~L} / \mathrm{s}$ & Verificar & Simplificado & Simplificado & Simplificado \\
\hline Ronaldo V. Gontijo & 432,00 & & & 120,00 & 3285,94 & $0,55 \%$ & $30,74 \%$ & $<500 \mathrm{~L} / \mathrm{s}$ & Verificar & $\mathrm{ICC}_{\text {máx }} \geq 30 \%$ & $\mathrm{ICI}_{\text {máx }} \geq 0,5 \%$ & Avançado \\
\hline Roberto Motta Pereira & 500,00 & & & 138,89 & 3424,83 & $0,64 \%$ & $30,74 \%$ & $<500 \mathrm{~L} / \mathrm{s}$ & Verificar & $\mathrm{ICC}_{\text {máx }} \geq 30 \%$ & $\mathrm{ICI}_{\text {máx }} \geq 0,5 \%$ & Avançado \\
\hline Sklar Agropecuária Ltda & 100,00 & & & 27,78 & 3452,61 & $0,13 \%$ & $30,74 \%$ & $<500 \mathrm{~L} / \mathrm{s}$ & Verificar & $\mathrm{ICC}_{\text {máx }} \geq 30 \%$ & $\mathrm{ICI}_{\text {máx }}<0,5 \%$ & Intermediário \\
\hline Geraldo E. dos Santos & 120,00 & & & 33,33 & 3485,94 & $0,15 \%$ & $30,74 \%$ & $<500 \mathrm{~L} / \mathrm{s}$ & Verificar & $\mathrm{ICC}_{\text {máx }} \geq 30 \%$ & $\mathrm{ICI}_{\text {máx }}<0,5 \%$ & Intermediário \\
\hline M $^{\mathrm{a}}$ Aparecida C. Santos & 120,00 & & & 33,33 & 3519,28 & $0,15 \%$ & $30,74 \%$ & $<500 \mathrm{~L} / \mathrm{s}$ & Verificar & $\mathrm{ICC}_{\text {máx }} \geq 30 \%$ & $\mathrm{ICI}_{\text {máx }}<0,5 \%$ & Intermediário \\
\hline Copasa Martinho Campos & & 62,00 & 90 & 383,19 & 3902,47 & $1,77 \%$ & $30,74 \%$ & $<500 \mathrm{~L} / \mathrm{s}$ & Verificar & $\mathrm{ICC}_{\text {máx }} \geq 30 \%$ & $\mathrm{ICI}_{\text {máx }} \geq 0,5 \%$ & Avançado \\
\hline Eugênio A. Costa Filho & 180,00 & & & 50,00 & 3952,47 & $0,23 \%$ & $30,74 \%$ & $<500 \mathrm{~L} / \mathrm{s}$ & Verificar & $\mathrm{ICC}_{\text {máx }} \geq 30 \%$ & $\mathrm{ICI}_{\text {máx }}<0,5 \%$ & Intermediário \\
\hline Francisco Lino - PI & 91,30 & & & 25,36 & 3977,83 & $0,12 \%$ & $30,74 \%$ & $<500 \mathrm{~L} / \mathrm{s}$ & Verificar & $\mathrm{ICC}_{\text {máx }} \geq 30 \%$ & $\mathrm{ICI}_{\text {máx }}<0,5 \%$ & Intermediário \\
\hline Francisco Lino - PII & 119,00 & & & 33,06 & 4010,89 & $0,15 \%$ & $30,74 \%$ & $<500 \mathrm{~L} / \mathrm{s}$ & Verificar & $\mathrm{ICC}_{\text {máx }} \geq 30 \%$ & $\mathrm{ICI}_{\text {máx }}<0,5 \%$ & Intermediário \\
\hline Geraldo M. Valadares & 144,00 & & & 40,00 & 4050,89 & $0,18 \%$ & $30,74 \%$ & $<500 \mathrm{~L} / \mathrm{s}$ & Verificar & $\mathrm{ICC}_{\text {máx }} \geq 30 \%$ & $\mathrm{ICI}_{\text {máx }}<0,5 \%$ & Intermediário \\
\hline Fernando Paulo T. Sousa & 324,00 & & & 90,00 & 4140,89 & $0,42 \%$ & $30,74 \%$ & $<500 \mathrm{~L} / \mathrm{s}$ & Verificar & $\mathrm{ICC}_{\text {máx }} \geq 30 \%$ & $\mathrm{ICI}_{\text {máx }}<0,5 \%$ & Intermediário \\
\hline
\end{tabular}




\subsubsection{Cálculo dos Índices Absolutos e Relativos}

Passando agora para a determinação dos índices absolutos (QAB1 e QAB2) e dos índices relativos (PCC, P1CI1, P1CI2, P2CI1 e P2CI2), verifica-se, para cada trecho i, se as vazões outorgadas atendem aos três indicadores gerais:

$\underline{1^{\mathrm{o}} \text { Indicador - Controle objetivo do monitoramento: }} \Sigma \mathrm{Q}_{\mathrm{dem}} 2(\mathrm{i})+\Sigma \mathrm{Q}_{\mathrm{dem}} 3(\mathrm{i}) \geq 0,8 \times \Sigma \mathrm{Q}_{\mathrm{dem}} \mathrm{T}(\mathrm{i})$ $\underline{2^{\circ} \text { Indicador - Verificação do real uso outorgado: }} \Sigma \mathrm{Q}_{\operatorname{dem}} 3$ (i) $\geq 0,4 \times \Sigma \mathrm{Q}_{\operatorname{dem}} \mathrm{T}$ (i)

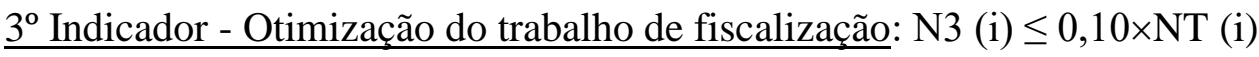

Sendo assim, levando em conta os dados dos 27 trechos da bacia do São Francisco, estabelecem-se a seguir diferentes cenários, com valores de índices absolutos e relativos distintos, a fim de verificar o atendimento aos três indicadores gerais.

\subsubsection{Cenário 1: Sem índices absolutos, índices relativos mais restritivos}

Como Cenário 1, idealizou-se a possibilidade de classificar os pontos de interferência outorgados num dos três estágios de exigência de monitoramento, somente utilizando os Índices de Comprometimento Individual (ICI máx) e Coletivo ( ICC $_{\text {máx }}$ ), ou seja, levando em conta somente valores relativos da vazão de demanda do ponto outorgado $Q_{\text {demanda }}$ com a vazão de

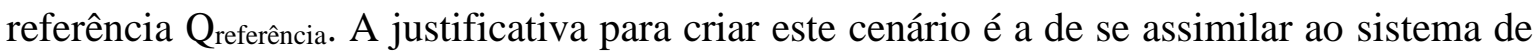
suporte à decisão do $\mathrm{SCBH}$, no sentido de verificar como um usuário influencia no trecho individualmente e coletivamente, e tomar uma decisão somente com os indicadores ICI e ICC, sem considerar valores de mínimo e máximo de vazão; em outras palavras, sem considerar os índices absolutos para classificação em termos de comparação com a $Q_{\text {demanda }}$ do ponto.

Para montar esse cenário, considerou-se então que os índices absolutos não influenciam na tomada de decisão. Assim, o índice de mínimo absoluto foi igualado a zero, ou seja, QAB1=0, e o índice de máximo absoluto foi igualado a um valor de 60.000 1/s, QAB2 = 60.001 1/s, valor este superior à maior vazão de demanda outorga em toda a bacia do rio São Francisco, que é o projeto Baixio de Irecê, pertencente à CODEVASF, no município de Xique-Xique/BA, com uma vazão de demanda $\mathrm{Q}_{\text {demanda }}=60.000,00$ 1/s. 
Para definição de valores para os índices relativos neste Cenário 1, serão considerados valores iniciais descritos no capítulo 4 (Metodologia), apresentados na Tabela 4.2, valores estes mais restritivos e conservadores para os índices PCC, P1CI1, P1CI2, P2CI1 e P2CI2. Com índices relativos mais restritivos, espera-se que as vazões outorgadas, comparadas com a vazão de referência no trecho, sejam mais significativas ao ponto de classificação em termos de monitoramento mais exigentes, no caso, de $2^{\circ}$ e $3^{\circ}$ nível de exigência (Intermediário e Avançado).

Apresenta-se a classificação dos pontos nos 27 trechos de acordo com as tabelas a seguir:

- $\quad 1^{\text {a }}$ Tabela - Trechos de menor disponibilidade hídrica (ou menor porte): 9 trechos, com vazões de referência $\mathrm{Q}_{\text {referencia }}<50.000$ 1/s, correspondentes à nascente do rio São Francisco (até o Reservatório de Três Marias), aos rios Bezerra, Preto (2 trechos), Urucuia, Carinhanha, Verde Grande e Verde Pequeno e o reservatório de UHE Queimado;

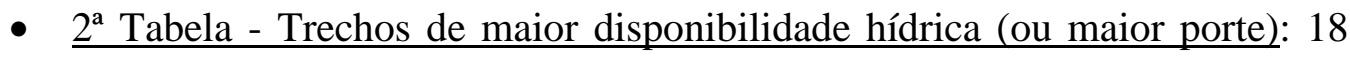
trechos, com vazões de referência $Q_{\text {referencia }}>150.000$ 1/s, sendo 13 destes constituintes da própria calha do rio São Francisco, excetuando a nascente, e de 5 reservatórios localizados na calha do rio: Três Marias, Sobradinho, Itaparica, Moxotó/Paulo Afonso e Xingó.

A separação dos trechos em duas tabelas, uma contendo os trechos de menor porte, e outra os de maior porte, serve para uma melhor visualização e interpretação dos resultados, uma vez que nos trechos de menor porte os pontos de interferência tendem a ter mais significância em termos individuais e coletivos, pois a vazão de referência nesses trechos é menor. 
Tabela 5.7 - Classificação dos pontos de interferência localizados nos 9 trechos de menor porte - Cenário 1

\begin{tabular}{|c|c|c|c|c|c|c|c|c|c|c|c|c|c|c|c|c|c|c|c|}
\hline $\begin{array}{c}\mathbf{N}^{\mathbf{o}} \text { Tre- } \\
\text { cho }\end{array}$ & $\begin{array}{l}\text { Localiza- } \\
\text { ção }\end{array}$ & $\begin{array}{l}\text { Ref. } \\
(\mathbf{l} / \mathbf{s})\end{array}$ & $\begin{array}{c}\text { NT to- } \\
\text { tal }\end{array}$ & $\begin{array}{l}\text { ICC } \\
(\%)\end{array}$ & $\begin{array}{c}\text { N1 } \\
\text { ptos }\end{array}$ & $\begin{array}{c}\% \\
\text { N1 }\end{array}$ & $\begin{array}{c}\text { N2 } \\
\text { ptos }\end{array}$ & $\begin{array}{c}\% \\
\mathrm{~N} 2\end{array}$ & \begin{tabular}{c|} 
N3 \\
ptos
\end{tabular} & $\begin{array}{c}\% \\
\text { N3 }\end{array}$ & QT (l/s) & Q1 (l/s) & $\% \mathbf{Q 1}$ & Q2 (l/s) & $\begin{array}{r}\% \\
\text { Q2 }\end{array}$ & Q3 (1/s) & $\begin{array}{r}\% \\
\text { Q3 }\end{array}$ & $\begin{array}{c}\text { Q2+Q3 } \\
(\mathrm{l} / \mathrm{s})\end{array}$ & $\begin{array}{c}\% \\
\mathrm{Q} 2+\mathrm{Q} 3\end{array}$ \\
\hline 1 & Nasc. R SF & 21.641 & 29 & $31 \%$ & 4 & $14 \%$ & 14 & $48 \%$ & 11 & $38 \%$ & 4.141 & 36 & $1 \%$ & 665 & $16 \%$ & 3.440 & $83 \%$ & 4.105 & $99 \%$ \\
\hline 5 & R. Bezerra & 4.000 & 23 & $88 \%$ & 0 & $0 \%$ & 2 & $9 \%$ & 21 & $91 \%$ & 3.312 & 0 & $0 \%$ & 11 & $0 \%$ & 3.301 & $100 \%$ & 3.312 & $100 \%$ \\
\hline 6 & Res.Queim. & 20.000 & 43 & $53 \%$ & 1 & $2 \%$ & 20 & $47 \%$ & 22 & $51 \%$ & 6.257 & 18 & $0 \%$ & 1.153 & $18 \%$ & 5.085 & $81 \%$ & 6.239 & $100 \%$ \\
\hline 7 & Rio Preto & 11.225 & 38 & $42 \%$ & 1 & $3 \%$ & 20 & $53 \%$ & 17 & $45 \%$ & 4.544 & 8 & $0 \%$ & 763 & $17 \%$ & 3.773 & $83 \%$ & 4.536 & $100 \%$ \\
\hline 8 & Rio Preto & 18.600 & 42 & $91 \%$ & 0 & $0 \%$ & 14 & $33 \%$ & 28 & $67 \%$ & 12.368 & 0 & $0 \%$ & 834 & $7 \%$ & 11.534 & $93 \%$ & 12.368 & $100 \%$ \\
\hline 10 & R. Urucuia & 26.400 & 54 & $62 \%$ & 8 & $15 \%$ & 19 & $35 \%$ & 27 & $50 \%$ & 16.360 & 109 & $1 \%$ & 1.635 & $10 \%$ & 14.616 & $89 \%$ & 16.251 & $99 \%$ \\
\hline 12 & R.Ver Gde & 3.300 & \begin{tabular}{l|l}
131 \\
\end{tabular} & $145 \%$ & 11 & $8 \%$ & 64 & $49 \%$ & 56 & $43 \%$ & 4.797 & 22 & $0 \%$ & 568 & $12 \%$ & 4.207 & $88 \%$ & 4.775 & $100 \%$ \\
\hline 13 & R Ver Peq & 800 & 45 & $140 \%$ & 5 & $11 \%$ & 22 & $49 \%$ & 18 & $40 \%$ & 1.122 & 3 & $0 \%$ & 41 & $4 \%$ & 1.078 & $96 \%$ & 1.119 & $100 \%$ \\
\hline 15 & R.Carinhanha & 31.800 & 27 & $55 \%$ & 9 & $33 \%$ & 10 & $37 \%$ & 8 & $30 \%$ & 16.760 & 151 & $1 \%$ & 503 & $3 \%$ & 16.106 & $96 \%$ & 16.608 & $99 \%$ \\
\hline $\begin{array}{c}\text { TOTAIS } \\
\text { SF }\end{array}$ & & 137.766 & 432 & & 39 & $9 \%$ & 85 & $43 \%$ & 208 & $48 \%$ & 69.661 & 348 & $0 \%$ & 6.171 & $9 \%$ & 63.142 & $91 \%$ & 69.313 & $100 \%$ \\
\hline
\end{tabular}

Tabela 5.8 - Classificação dos pontos de interferência localizados nos 18 trechos de maior porte - Cenário 1

\begin{tabular}{|c|c|c|c|c|c|c|c|c|c|c|c|c|c|c|c|c|c|c|c|}
\hline $\begin{array}{c}\mathbf{N}^{0} \text { Tre- } \\
\text { cho }\end{array}$ & $\begin{array}{l}\text { Localiza- } \\
\text { ção }\end{array}$ & $\begin{array}{l}\text { Qref } \\
(1 / s)\end{array}$ & $\begin{array}{c}\text { NT to- } \\
\text { tal }\end{array}$ & $\begin{array}{l}\text { ICC } \\
(\%)\end{array}$ & $\begin{array}{c}\text { N1 } \\
\text { ptos }\end{array}$ & $\% \mathrm{~N} 1$ & $\begin{array}{c}\text { N2 } \\
\text { ptos }\end{array}$ & $\begin{array}{c}\% \\
\mathrm{~N} 2 \\
\end{array}$ & $\begin{array}{c}\text { N3 } \\
\text { ptos }\end{array}$ & $\begin{array}{c}\% \\
\mathrm{N3}\end{array}$ & $\begin{array}{l}\text { QT } \\
(1 / s)\end{array}$ & Q1 (l/s) & $\begin{array}{r}\% \\
\text { Q1 } \\
\end{array}$ & $\begin{array}{c}\mathbf{Q 2} \\
(\mathbf{l} / \mathbf{s})\end{array}$ & $\begin{array}{r}\% \\
\text { Q2 } \\
\end{array}$ & $\begin{array}{c}\text { Q3 } \\
(1 / s)\end{array}$ & $\begin{array}{r}\% \\
\text { Q3 }\end{array}$ & \begin{tabular}{|c|}
$\mathbf{Q} 2+\mathbf{Q 3}$ \\
$(\mathbf{l} / \mathbf{s})$ \\
\end{tabular} & $\begin{array}{c}\% \\
\mathrm{Q} 2+\mathrm{Q} 3 \\
\end{array}$ \\
\hline 2 & 3 Marias & 155.000 & 57 & $10,0 \%$ & 53 & $93 \%$ & 4 & $7 \%$ & 0 & $0 \%$ & 7.006 & 5.158 & $74 \%$ & 1.849 & $26 \%$ & 0 & $0 \%$ & 1.849 & $26 \%$ \\
\hline 3 & Rio SF & 350.100 & 53 & $6,3 \%$ & 44 & $83 \%$ & 9 & $17 \%$ & 0 & $0 \%$ & 15.945 & 6.789 & $43 \%$ & 9.156 & $57 \%$ & 0 & $0 \%$ & 9.156 & $57 \%$ \\
\hline 4 & Rio SF & 396.100 & 11 & $9,7 \%$ & 10 & $91 \%$ & 1 & $9 \%$ & 0 & $0 \%$ & 2.831 & 1.961 & $69 \%$ & 870 & $31 \%$ & 0 & $0 \%$ & 870 & $31 \%$ \\
\hline 9 & Rio SF & 451.200 & 10 & $17,1 \%$ & 9 & $90 \%$ & 1 & $10 \%$ & 0 & $0 \%$ & 3.404 & 1.327 & $39 \%$ & 2.076 & $61 \%$ & 0 & $0 \%$ & 2.076 & $61 \%$ \\
\hline 11 & Rio SF & 478.900 & 60 & $37,2 \%$ & 49 & $82 \%$ & 8 & $13 \%$ & 3 & $5 \%$ & 86.777 & 3.505 & $4 \%$ & 8.016 & $9 \%$ & 75.257 & $87 \%$ & 83.273 & $96 \%$ \\
\hline 14 & Rio SF & 530.650 & 13 & $41,5 \%$ & 11 & $85 \%$ & 2 & $15 \%$ & 0 & $0 \%$ & 1.815 & 300 & $17 \%$ & 1.515 & $83 \%$ & 0 & $0 \%$ & 1.515 & $83 \%$ \\
\hline 16 & Rio SF & 550.100 & 22 & $43,2 \%$ & 22 & $100 \%$ & 0 & $0 \%$ & 0 & $0 \%$ & 2.449 & 2.449 & $100 \%$ & 0 & $0 \%$ & 0 & $0 \%$ & 0 & $0 \%$ \\
\hline 17 & Rio SF & 595.553 & 23 & $46,7 \%$ & 21 & $91 \%$ & 2 & $9 \%$ & 0 & $0 \%$ & 3.775 & 1.244 & $33 \%$ & 2.531 & $67 \%$ & 0 & $0 \%$ & 2.531 & $67 \%$ \\
\hline 18 & Rio SF & 622.629 & 12 & $46,8 \%$ & 11 & $92 \%$ & 1 & $8 \%$ & 0 & $0 \%$ & 2.152 & 1.409 & $65 \%$ & 743 & $35 \%$ & 0 & $0 \%$ & 743 & $35 \%$ \\
\hline 19 & Rio SF & 717.869 & 19 & $64,1 \%$ & 17 & $89 \%$ & 1 & $5 \%$ & 1 & $5 \%$ & 62.894 & 2.006 & $3 \%$ & 889 & $1 \%$ & 60.000 & $95 \%$ & 60.889 & $97 \%$ \\
\hline 20 & Sobradinho & 758.934 & 185 & $51,3 \%$ & 180 & $97 \%$ & 4 & $2 \%$ & 1 & $1 \%$ & 40.903 & 13.320 & $33 \%$ & 4.383 & $11 \%$ & 23.200 & $57 \%$ & 27.583 & $67 \%$ \\
\hline 21 & Rio SF & 800.000 & 282 & $19,8 \%$ & 273 & $97 \%$ & 6 & $2 \%$ & 3 & $1 \%$ & 158.123 & 19.583 & $12 \%$ & 33.796 & $21 \%$ & 104.744 & $66 \%$ & 138.541 & $88 \%$ \\
\hline 22 & Rio SF & 800.000 & 115 & $23,5 \%$ & 110 & $96 \%$ & 3 & $3 \%$ & 2 & $2 \%$ & 69.321 & 6.461 & $9 \%$ & 10.061 & $15 \%$ & 52.800 & $76 \%$ & 62.861 & $91 \%$ \\
\hline 23 & Itaparica & 800.000 & 345 & $21,4 \%$ & 342 & $99 \%$ & 3 & $1 \%$ & 0 & $0 \%$ & 20.493 & 12.423 & $61 \%$ & 8.070 & $39 \%$ & 0 & $0 \%$ & 8.070 & $39 \%$ \\
\hline 24 & Mox/ P. Af. & 800.000 & 36 & $10,0 \%$ & 29 & $81 \%$ & 5 & $14 \%$ & 2 & $6 \%$ & 79.067 & 2.865 & $4 \%$ & 22.358 & $28 \%$ & 53.843 & $68 \%$ & 76.202 & $96 \%$ \\
\hline 25 & Xingó & 800.000 & 15 & $1,9 \%$ & 13 & $87 \%$ & 1 & $7 \%$ & 1 & $7 \%$ & 13.373 & 521 & $4 \%$ & 3.042 & $23 \%$ & 9.810 & $73 \%$ & 12.853 & $96 \%$ \\
\hline 26 & Rio SF & 800.000 & 14 & $3,3 \%$ & 13 & $93 \%$ & 1 & $7 \%$ & 0 & $0 \%$ & 5.487 & 771 & $14 \%$ & 4.716 & $86 \%$ & 0 & $0 \%$ & 4.716 & $86 \%$ \\
\hline 27 & Rio SF & 800.000 & 56 & $10,1 \%$ & 49 & $88 \%$ & 6 & $11 \%$ & 1 & $2 \%$ & 55.143 & 16.348 & $30 \%$ & 22.295 & $40 \%$ & 16.500 & $30 \%$ & 38.795 & $70 \%$ \\
\hline $\begin{array}{c}\text { TOTAIS } \\
\text { SF } \\
\end{array}$ & & & 1.328 & & 1.256 & $95 \%$ & 58 & $4 \%$ & 14 & $1 \%$ & 630.960 & 98.439 & $16 \%$ & 136.366 & $22 \%$ & 396.155 & $63 \%$ & 532.521 & $84 \%$ \\
\hline
\end{tabular}


Conforme esperado, observa-se na Tabela 5.7 que, nos trechos de menor porte - rios de domínio da União afluentes do rio São Francisco - as vazões outorgadas foram classificadas, em sua maioria, no estágio 2 (monitoramento intermediário), com N2 $=43 \%$, e no estágio 3 (monitoramento avançado com instalação de equipamento), com N3 =48\%. Com índices relativos mais restritivos, em corpos d'água de menor porte, as vazões outorgadas terão maior significância, pois a vazão de referência é menor e a relação entre as vazões: $Q_{\text {de- }}$ manda $/ Q_{\text {referencia }}$ terá um valor mais significativo, isto é, obteremos valores maiores para $\mathrm{ICI}_{\text {máx }}$ e $\mathrm{ICC}_{\text {máx }}$, acarretando na classificação dos pontos nos dois estágios de maior exigência.

Neste Cenário 1, para os rios de menor porte, pelo número excessivo de pontos concentrados no $3^{\circ}$ estágio, tem-se $\mathrm{N} 3=0,48 \mathrm{NT}$, o que não atende ao previsto no $3^{\circ}$ indicador geral, de se ter um número de pontos no $3^{\circ}$ estágio em até em $10 \%$ do número total de pontos de interferência $(\mathrm{N} 3 \leq 0,1 \times \mathrm{NT})$. Tem-se ainda um controle de monitoramento entre os estágios 2 e 3 próximos de $100 \%$, ou seja, as vazões de demanda dos pontos classificados entre os estágios 2 e 3 são próximas da vazão total outorgada $(\mathrm{Q} 2+\mathrm{Q} 3 \cong \mathrm{QT})$. Além disso, Q3 = 0,91 QT. Ora, os indicadores gerais $1(\mathrm{Q} 2+\mathrm{Q} 3 \geq 0,8 \times \mathrm{QT})$ e $2(\mathrm{Q} 3 \geq 0,4 \times \mathrm{QT})$ estariam sendo atendidos, mas num número bem acima, indicando um excessivo controle das vazões outorgadas. Levando em conta esses 8 trechos de menor porte (Tabela 5.7), os índices relativos deveriam ser menos restritivos, de forma que se tenha mais pontos de interferência nos estágios 1 e 2, de menor exigência quanto ao monitoramento, e menos pontos no último estágio.

Por outro lado, nos trechos de maior porte - localizados na calha do rio São Francisco e nos reservatórios da calha do referido rio $-95 \%$ dos pontos de interferência são N1, ou seja, estão classificados no estágio 1 (simplificado), 4\% são N2, com monitoramento intermediário, e somente $1 \%$ são N3, com exigência de instalar equipamento de medição. Todos os indicadores gerais estariam sendo atendidos, uma vez que esses $1 \%$ dos pontos de interferência estão no $3^{\circ}$ nível de exigência, atendendo ao $3^{\circ}$ indicador $(\mathrm{N} 3 \leq 0,1 \mathrm{NT})$. Estes pontos são responsáveis por $63 \%$ da vazão outorgada $(\mathrm{Q} 3=0,63 \mathrm{QT})$, estando de acordo com o $2^{\circ}$ indicador geral $(\mathrm{Q} 3 \geq 0,4 \times \mathrm{QT})$ e, além disso, as vazões $\mathrm{Q} 2+\mathrm{Q} 3=0,84 \mathrm{QT}$, atendendo também ao $1^{\circ}$ indicador $(\mathrm{Q} 2+\mathrm{Q} 3 \geq 0,8 \times \mathrm{QT})$. Considerando somente os trechos de maior porte, os índices relativos menos restritivos já seriam satisfatórios para classificação dos pontos nos três estágios. 
Entretanto, no que diz respeito ao número de usuários do tipo N3, apesar de ser satisfatório (N3 $\leq 0,1 \mathrm{NT})$, não seria um número "otimizado". Isso porque, ao considerar somente valores relativos, que visam proporcionar a relação $\mathrm{Q}_{\text {demanda }} / \mathrm{Q}_{\text {referência, }}$ em rios de maior porte, deixase de dar importância às outorgas concedidas aos empreendimentos de maior envergadura como, por exemplo, vários perímetros de irrigação localizados na calha do rio São Francisco. É razoável se pensar que, em relação à fiscalização do uso de recursos hídricos, para um empreendimento de maior envergadura deva ser exigido um monitoramento objetivo com, no mínimo, a instalação de um horímetro (estágio 2) ou de um equipamento de medição (estágio 3), independente do trecho em que se encontra.

Exemplificando: a Companhia Hidro Elétrica do São Francisco - CHESF foi outorgada pela ANA mediante a Resolução nº 389, de 22 de agosto de 2012, para retirada de água no açude Moxotó, com finalidade de irrigação do Projeto Jusante, cuja $\mathrm{Q}_{\text {demanda }}=1.200$ 1/s (Brasil, 2012). Ora, entre os trechos 21 e 27, ou seja, a jusante da barragem de Sobradinho até a foz do rio São Francisco, a vazão de referência é regularizada em 800.000 1/s $(800$ m³/s) pelos reservatórios em cascata. Este ponto de captação da CHESF teria então uma contribuição individual de $\mathrm{CI}=1 \cdot 200 / 800.000=0,0015=0,15 \%$. No Trecho 24 , correspondente ao açude Moxotó, o $\mathrm{ICC}_{\text {máx }}$ é igual a $10 \%$ (vide Tabela 5.8 acima) e, portanto, o comprometimento coletivo neste trecho é baixo, inferior aos $30 \%$ estipulados para o índice coletivo PCC. Sendo assim, tomando somente os índices relativos, então este ponto de interferência seria classificado como "monitoramento simplificado". Um projeto de irrigação com essa $Q_{\text {demanda }}$ deve, por si só, independentemente da localização, ser classificado com uma exigência de monitoramento intermediário, no mínimo.

Cabe aqui dimensionar o que é um ponto de interferência como esse, que faça captação de 1.200 1/s. O cultivo de banana, em termos de irrigação, por exemplo, tem um consumo médio de 0,72 1/s/ha (Silva Neto, 2011). Ora, 1.200 1/s são suficientes para produção de aproximadamente 1.700 ha de banana. Levando em conta que um pivô cobre uma área média de 107 ha (Spagnolo et al., 2012), então 1.200 1/s é água suficiente para abastecer 16 pivôs centrais para irrigação de banana. Logo, um empreendimento deste porte, localizado no trecho 24 , seria classificado como Nível 1, ou seja, como "monitoramento simplificado".

Verifica-se, portanto, a necessidade de aperfeiçoamento da classificação, criando outros Cenários, por duas medidas: 
1) Revisão dos índices relativos para valores menos restritivos;

2) Inclusão de valores absolutos.

5.3.3.2 Cenário 2: Sem índices absolutos, índices relativos menos restritivos

Como Cenário 2, adotam-se índices relativos menos restritivos, de forma tal que os pontos de interferência nos trechos de menor porte da bacia do São Francisco não fiquem concentrados nas classificações de maior exigência: monitoramento intermediário e avançado. Neste novo Cenário, ainda não se levou em conta os índices absolutos, propositadamente, para ver como a mudança dos índices relativos afetam os trechos.

Índice relativo coletivo (PCC) - conforme visto no item 4.6.2, pelos critérios adotados para outorga, um valor de Indicador de Comprometimento Coletivo com maior relevância seria em torno de 0,5 (50\%). Numa situação menos restritiva, adota-se agora: $\mathrm{PCC}=0,7$, ou seja, $\mathrm{ICC}_{\text {máx }}<70 \%$ tem menor relevância, e $\mathrm{ICC}_{\max } \geq 70 \%$ é considerado mais relevante.

Índices relativos individuais (P1CI1, P1CI2, P2CI1 e P2CI2) - no que tange aos índices individuais, partindo para valores menos conservadores, adotam-se P1CI1 = 0,01 (1,0\%) e $\mathrm{P} 1 \mathrm{CI} 2=0,06(6 \%)$ para os trechos com ICCmáx < 70\%. Em relação aos trechos mais críticos, com $\mathrm{ICC}_{\text {máx }} \geq 70 \%$, tomam-se P2CI1 = 0,005 (0,5\%) e P2CI2 = 0,03 (3\%).

Os resultados dos cálculos para o Cenário 2 são apresentados nas tabelas 5.9 e 5.10 a seguir, juntando os trechos de menor porte na primeira e os de maior porte na segunda. 
Tabela 5.9 - Classificação dos pontos de interferência localizados nos 9 trechos de menor porte - Cenário 2

\begin{tabular}{|c|c|c|c|c|c|c|c|c|c|c|c|c|c|c|c|c|c|c|c|}
\hline $\begin{array}{c}N^{0} \text { Tre- } \\
\text { cho }\end{array}$ & $\begin{array}{l}\text { Localiza- } \\
\text { ção }\end{array}$ & $\begin{array}{c}\text { Qref } \\
(1 / s)\end{array}$ & $\begin{array}{c}\text { NT to- } \\
\text { tal }\end{array}$ & $\begin{array}{l}\text { ICC } \\
(\%)\end{array}$ & $\begin{array}{c}\text { N1 } \\
\text { ptos }\end{array}$ & $\begin{array}{c}\% \\
\text { N1 }\end{array}$ & $\begin{array}{l}\text { N2 } \\
\text { ptos }\end{array}$ & $\begin{array}{l}\% \\
\mathrm{~N} 2\end{array}$ & $\begin{array}{c}\text { N3 } \\
\text { ptos }\end{array}$ & $\begin{array}{l}\% \\
\text { N3 }\end{array}$ & QT (l/s) & Q1 (l/s) & $\begin{array}{l}\% \\
\text { Q1 }\end{array}$ & Q2 (1/s) & $\begin{array}{l}\% \\
\text { Q2 }\end{array}$ & Q3 $\quad(1 / s)$ & $\begin{array}{r}\% \\
\text { Q3 }\end{array}$ & $\begin{array}{c}\mathbf{Q} 2+\mathbf{Q 3} \\
(\mathbf{l} / \mathbf{s})\end{array}$ & $\begin{array}{c}\% \\
\mathrm{Q} 2+\mathrm{Q} 3\end{array}$ \\
\hline 1 & Nasc. R SF & 21.641 & 29 & $31 \%$ & 23 & $79 \%$ & 6 & $21 \%$ & 0 & $0 \%$ & 4.141 & 1.488 & $36 \%$ & 2.653 & $64 \%$ & 0 & $0 \%$ & 2.653 & $64 \%$ \\
\hline 5 & R. Bezerra & 4.000 & 23 & $88 \%$ & 2 & $9 \%$ & 11 & $48 \%$ & 10 & $43 \%$ & 3.312 & 11 & $0 \%$ & 780 & $24 \%$ & 2.521 & $76 \%$ & 3.301 & $100 \%$ \\
\hline 6 & Res.Queim. & 20.000 & 43 & $53 \%$ & 36 & $84 \%$ & 7 & $16 \%$ & 0 & $0 \%$ & 6.257 & 3.171 & $51 \%$ & 3.086 & $49 \%$ & 0 & $0 \%$ & 3.086 & $49 \%$ \\
\hline 7 & Rio Preto & 11.225 & 38 & $42 \%$ & 32 & $84 \%$ & 5 & $13 \%$ & 1 & $3 \%$ & 4.544 & 1.737 & $38 \%$ & 1.414 & $31 \%$ & 1.393 & $31 \%$ & 2.807 & $62 \%$ \\
\hline 8 & Rio Preto & 18.600 & 42 & $91 \%$ & 14 & $33 \%$ & 22 & $52 \%$ & 6 & $14 \%$ & 12.368 & 834 & $7 \%$ & 4.929 & $40 \%$ & 6.606 & $53 \%$ & 11.534 & $93 \%$ \\
\hline 10 & R. Urucuia & 26.400 & 54 & $62 \%$ & 36 & $67 \%$ & 17 & $31 \%$ & 1 & $2 \%$ & 16.360 & 3.475 & $21 \%$ & 10.912 & $67 \%$ & 1.973 & $12 \%$ & 12.885 & $79 \%$ \\
\hline 12 & R.Ver Gde & 3.300 & 131 & $145 \%$ & 75 & $57 \%$ & 41 & $31 \%$ & 15 & $11 \%$ & 4.797 & 590 & $12 \%$ & 1.950 & $41 \%$ & 2.257 & $47 \%$ & 4.207 & $88 \%$ \\
\hline 13 & R Ver Peq & 800 & 45 & $140 \%$ & 27 & $60 \%$ & 16 & $36 \%$ & 2 & $4 \%$ & 1.122 & 43 & $4 \%$ & 105 & $9 \%$ & 974 & $87 \%$ & 1.078 & $96 \%$ \\
\hline $15 \mathrm{I}$ & R.Carinhanha & 31.800 & 27 & $55 \%$ & 21 & $78 \%$ & 1 & $4 \%$ & 5 & $19 \%$ & 16.760 & 1.176 & $7 \%$ & 583 & $3 \%$ & 15.000 & $89 \%$ & 15.583 & $93 \%$ \\
\hline $\begin{array}{c}\text { TOTAIS } \\
\text { SF }\end{array}$ & & 137.766 & 432 & & 66 & $62 \%$ & 126 & $29 \%$ & 40 & $9 \%$ & .661 & 2.525 & $18 \%$ & 6.412 & $38 \%$ & 0.724 & $44 \%$ & 57.136 & $2 \%$ \\
\hline
\end{tabular}

Tabela 5.10 - Classificação dos pontos de interferência localizados nos 18 trechos de maior porte - Cenário 2

\begin{tabular}{|c|c|c|c|c|c|c|c|c|c|c|c|c|c|c|c|c|c|c|c|}
\hline $\begin{array}{l}N^{0} \text { Tre- } \\
\text { cho }\end{array}$ & $\begin{array}{l}\text { Localiza- } \\
\text { ção }\end{array}$ & $\begin{array}{l}\text { Qref } \\
(\mathbf{l} / \mathbf{s})\end{array}$ & $\begin{array}{c}\text { NT to- } \\
\text { tal }\end{array}$ & $\begin{array}{l}\text { ICC } \\
(\%)\end{array}$ & $\begin{array}{c}\text { N1 } \\
\text { ptos }\end{array}$ & $\% \mathrm{~N} 1$ & $\begin{array}{c}\text { N2 } \\
\text { ptos }\end{array}$ & $\begin{array}{c}\% \\
\text { N2 }\end{array}$ & $\begin{array}{c}\text { N3 } \\
\text { ptos }\end{array}$ & $\begin{array}{c}\% \\
\text { N3 }\end{array}$ & $\begin{array}{l}\text { QT } \\
(\mathbf{l} / \mathbf{s})\end{array}$ & Q1 (l/s) & $\begin{array}{r}\% \\
\text { Q1 }\end{array}$ & $\begin{array}{c}\text { Q2 } \\
(\mathbf{l} / \mathbf{s})\end{array}$ & $\begin{array}{r}\% \\
\text { Q2 }\end{array}$ & $\begin{array}{c}\text { Q3 } \\
(\mathbf{l} / \mathbf{s})\end{array}$ & $\begin{array}{r}\% \\
\text { Q3 }\end{array}$ & $\begin{array}{c}\mathbf{Q} 2+\mathbf{Q 3} \\
(\mathbf{l} / \mathbf{s})\end{array}$ & $\begin{array}{c}\% \\
\mathrm{Q} 2+\mathrm{Q} 3\end{array}$ \\
\hline 2 & 3 Marias & 155.000 & 57 & $10,0 \%$ & 57 & $100 \%$ & 0 & $0 \%$ & 0 & $0 \%$ & 7.006 & 7.006 & $100 \%$ & 0 & $0 \%$ & 0 & $0 \%$ & 0 & $0 \%$ \\
\hline 3 & Rio SF & 350.100 & 53 & $6,3 \%$ & 53 & $100 \%$ & 0 & $0 \%$ & 0 & $0 \%$ & 15.945 & 15.945 & $100 \%$ & 0 & $0 \%$ & 0 & $0 \%$ & 0 & $0 \%$ \\
\hline 4 & Rio SF & 396.100 & 11 & $9,7 \%$ & 11 & $100 \%$ & 0 & $0 \%$ & 0 & $0 \%$ & 2.831 & 2.831 & $100 \%$ & 0 & $0 \%$ & 0 & $0 \%$ & 0 & $0 \%$ \\
\hline 9 & Rio SF & 451.200 & 10 & $17,1 \%$ & 10 & $100 \%$ & 0 & $0 \%$ & 0 & $0 \%$ & 3.404 & 3.404 & $100 \%$ & 0 & $0 \%$ & 0 & $0 \%$ & 0 & $0 \%$ \\
\hline 11 & Rio SF & 478.900 & 60 & $37,2 \%$ & 58 & $97 \%$ & 1 & $2 \%$ & 1 & $2 \%$ & 86.777 & 15.570 & $18 \%$ & 13.333 & $15 \%$ & 57.874 & $67 \%$ & 71.207 & $82 \%$ \\
\hline 14 & Rio SF & 530.650 & 13 & $41,5 \%$ & 13 & $100 \%$ & 0 & $0 \%$ & 0 & $0 \%$ & 1.815 & 1.815 & $100 \%$ & 0 & $0 \%$ & 0 & $0 \%$ & 0 & $0 \%$ \\
\hline 16 & Rio SF & 550.100 & 22 & $43,2 \%$ & 22 & $100 \%$ & 0 & $0 \%$ & 0 & $0 \%$ & 2.449 & 2.449 & $100 \%$ & 0 & $0 \%$ & 0 & $0 \%$ & 0 & $0 \%$ \\
\hline 17 & Rio SF & 595.553 & 23 & $46,7 \%$ & 23 & $100 \%$ & 0 & $0 \%$ & 0 & $0 \%$ & 3.775 & 3.775 & $100 \%$ & 0 & $0 \%$ & 0 & $0 \%$ & 0 & 0\% \\
\hline 18 & Rio SF & 622.629 & 12 & $46,8 \%$ & 12 & $100 \%$ & 0 & $0 \%$ & 0 & $0 \%$ & 2.152 & 2.152 & $100 \%$ & 0 & $0 \%$ & 0 & $0 \%$ & 0 & $0 \%$ \\
\hline 19 & Rio SF & 717.869 & 19 & $64,1 \%$ & 18 & $95 \%$ & 0 & $0 \%$ & 1 & $5 \%$ & 62.894 & 2.894 & $5 \%$ & 0 & $0 \%$ & 60.000 & $95 \%$ & 60.000 & $95 \%$ \\
\hline 20 & Sobradinho & 758.934 & 185 & $51,3 \%$ & 184 & $99 \%$ & 1 & $1 \%$ & 0 & $0 \%$ & 40.903 & 17.703 & $43 \%$ & 23.200 & $57 \%$ & 0 & $0 \%$ & 23.200 & $57 \%$ \\
\hline 21 & Rio SF & 800.000 & 282 & $19,8 \%$ & 279 & $99 \%$ & 3 & $1 \%$ & 0 & $0 \%$ & 158.123 & 53.379 & $34 \%$ & 104.744 & $66 \%$ & 0 & 0\% & 104.744 & $66 \%$ \\
\hline 22 & Rio SF & 800.000 & 115 & $23,5 \%$ & 113 & $98 \%$ & 2 & $2 \%$ & 0 & $0 \%$ & 69.321 & 16.521 & $24 \%$ & 52.800 & $76 \%$ & 0 & $0 \%$ & 52.800 & $76 \%$ \\
\hline 23 & Itaparica & 800.000 & 345 & $21,4 \%$ & 345 & $100 \%$ & 0 & $0 \%$ & 0 & $0 \%$ & 20.493 & 20.493 & $100 \%$ & 0 & $0 \%$ & 0 & 0\% & 0 & $0 \%$ \\
\hline 24 & Mox/ P. Af. & 800.000 & 36 & $10,0 \%$ & 34 & $94 \%$ & 2 & $6 \%$ & 0 & $0 \%$ & 79.067 & 25.223 & $32 \%$ & 53.843 & $68 \%$ & 0 & $0 \%$ & 53.843 & $68 \%$ \\
\hline 25 & Xingó & 800.000 & 15 & $1,9 \%$ & 14 & $93 \%$ & 1 & $7 \%$ & 0 & $0 \%$ & 13.373 & 3.563 & $27 \%$ & 9.810 & $73 \%$ & 0 & $0 \%$ & 9.810 & $73 \%$ \\
\hline 26 & Rio SF & 800.000 & 14 & $3,3 \%$ & 14 & $100 \%$ & 0 & $0 \%$ & 0 & $0 \%$ & 5.487 & 5.487 & $100 \%$ & 0 & $0 \%$ & 0 & $0 \%$ & 0 & $0 \%$ \\
\hline 27 & Rio SF & 800.000 & 56 & $10,1 \%$ & 55 & $98 \%$ & 1 & $2 \%$ & 0 & $0 \%$ & 55.143 & 38.643 & $70 \%$ & 16.500 & $30 \%$ & 0 & $0 \%$ & 16.500 & $30 \%$ \\
\hline $\begin{array}{c}\text { TOTAIS } \\
\text { SF }\end{array}$ & & & 1.328 & & 1.315 & $99 \%$ & 11 & $1 \%$ & 2 & $0 \%$ & 630.960 & 238.855 & $38 \%$ & 274.232 & $43 \%$ & 117.874 & $19 \%$ & 392.105 & $62 \%$ \\
\hline
\end{tabular}


Pelos resultados apresentados no Cenário 2, constata-se uma melhor conformação nos rios de menor porte (vide Tabela 5.9) no que diz respeito à distribuição dos pontos de interferência classificados, estando em conformação com os três indicadores gerais. Tem-se um número reduzido de 40 dos 432 pontos nesses trechos $(\mathrm{N} 3=0,09 \mathrm{NT}$ ) no estágio 3 (com maior exigência) correspondendo à $44 \%$ da vazão outorgada $(\mathrm{Q} 3=0,44 \mathrm{QT})$ e, além disso, o total da vazão do controle objetivo correspondem à praticamente $100 \%$ da vazão outorgada $(\mathrm{Q} 2$ $+\mathrm{Q} 3 \cong \mathrm{QT})$.

Entretanto, para os trechos de maior porte, verifica-se que somente 2 pontos dentre os 1.328 encontram-se no maior nível de exigência (estágio 3), 11 estão no estágio 2, e 1315 (99\%) são classificados como monitoramento simplificado (estágio 1). Com isso, os indicadores gerais 1 e 2 não são atendidos: Q3 corresponde à 19\% de QT, sendo que o Indicador 1 prevê que Q3 $\geq 0,4$ QT; e Q2 + Q3 iguala à 62\% de QT, mas o Indicador 2 prevê Q2 + Q3 $\geq 0,8$ QT.

\subsubsection{Cenário 3: Sem índices absolutos, índices relativos intermediários}

Para o Cenário 3, adotam-se índices relativos intermediários, a fim de verificar uma melhor conformação de classificação das vazões outorgadas, tanto nos trechos de menor porte, quanto nos de maior porte. Neste Cenário, também não se levou em conta os índices absolutos, propositadamente, para ver como a mudança dos índices relativos afetam os trechos.

Índice relativo coletivo (PCC) - conforme visto no item 4.6.2, pelos critérios adotados para outorga, um valor de Indicador de Comprometimento Coletivo com maior relevância seria em torno de 0,5 (50\%), adotando este valor como índice intermediário em termos coletivos, ou seja, $\mathrm{PCC}=0,5$.

Índices relativos individuais (P1CI1, P1CI2, P2CI1 e P2CI2) - no que tange aos índices individuais, partindo para valores intermediários entre o Cenário 1 e o Cenário 2, adotam-se $\mathrm{P} 1 \mathrm{CI} 1=0,005(0,5 \%)$ e P1CI2 = 0,05 (5\%) para os trechos com ICCmáx < 50\%. Em relação aos trechos mais críticos, com $\mathrm{ICC}_{\text {máx }} \geq 70 \%$, tomam-se P2CI1 = 0,003 $(0,3 \%)$ e P2CI2 = 0,03 (3\%). Os resultados dos cálculos para o Cenário 3 são apresentados nas tabelas 5.11 e 5.12 a seguir: 
Tabela 5.11 - Classificação dos pontos de interferência localizados nos 9 trechos de menor porte - Cenário 3

\begin{tabular}{|c|c|c|c|c|c|c|c|c|c|c|c|c|c|c|c|c|c|c|c|}
\hline $\begin{array}{l}N^{\circ} \text { Tre- } \\
\text { cho }\end{array}$ & $\begin{array}{l}\text { Localiza- } \\
\text { ção }\end{array}$ & $\begin{array}{l}\text { Qref } \\
(1 / s)\end{array}$ & $\begin{array}{c}\text { NT to- } \\
\text { tal }\end{array}$ & $\begin{array}{l}\text { ICC } \\
(\%)\end{array}$ & $\begin{array}{c}\text { N1 } \\
\text { ptos }\end{array}$ & $\begin{array}{l}\% \\
\text { N1 }\end{array}$ & $\begin{array}{c}\text { N2 } \\
\text { ptos }\end{array}$ & $\begin{array}{c}\% \\
\mathrm{~N} 2\end{array}$ & $\begin{array}{l}\text { N3 } \\
\text { ptos }\end{array}$ & $\begin{array}{l}\% \\
\text { N3 }\end{array}$ & QT (l/s) & Q1 (1/s) & $\begin{array}{r}\% \\
\text { Q1 }\end{array}$ & Q2 (l/s) & $\begin{array}{r}\% \\
\text { Q2 }\end{array}$ & Q3 $\quad(1 / s)$ & $\begin{array}{r}\% \\
\text { Q3 }\end{array}$ & $\begin{array}{c}\mathbf{Q} 2+\mathbf{Q 3} \\
(\mathbf{l} / \mathbf{s})\end{array}$ & $\begin{array}{c}\% \\
\mathrm{Q} 2+\mathrm{Q} 3\end{array}$ \\
\hline 1 & Nasc. R SF & 21.641 & 29 & $31 \%$ & 18 & $62 \%$ & 11 & $38 \%$ & 0 & $0 \%$ & 4.141 & 701 & $17 \%$ & 3.440 & $83 \%$ & 0 & $0 \%$ & 3.440 & $83 \%$ \\
\hline 5 & R. Bezerra & 4.000 & 23 & $88 \%$ & 2 & $9 \%$ & 11 & $48 \%$ & 10 & $43 \%$ & 3.312 & 11 & $0 \%$ & 780 & $24 \%$ & 2.521 & $76 \%$ & 3.301 & $100 \%$ \\
\hline 6 & Res.Queim. & 20.000 & 43 & $53 \%$ & 12 & $28 \%$ & 30 & $70 \%$ & 1 & $2 \%$ & 6.257 & 457 & $7 \%$ & 5.100 & $82 \%$ & 700 & $11 \%$ & 5.800 & $93 \%$ \\
\hline 7 & Rio Preto & 11.225 & 38 & $42 \%$ & 21 & $55 \%$ & 16 & $42 \%$ & 1 & $3 \%$ & 4.544 & 771 & $17 \%$ & 2.380 & $52 \%$ & 1.393 & $31 \%$ & 3.773 & $83 \%$ \\
\hline 8 & Rio Preto & 18.600 & 42 & $91 \%$ & 6 & $14 \%$ & 30 & $71 \%$ & 6 & $14 \%$ & 12.368 & 252 & $2 \%$ & 5.511 & $45 \%$ & 6.606 & $53 \%$ & 12.117 & $98 \%$ \\
\hline 10 & R. Urucuia & 26.400 & 54 & $62 \%$ & 15 & $28 \%$ & 32 & $59 \%$ & 7 & $13 \%$ & 16.360 & 468 & $3 \%$ & 7.736 & $47 \%$ & 8.157 & $50 \%$ & 15.893 & $97 \%$ \\
\hline 12 & R.Ver Gde & 3.300 & 131 & $145 \%$ & 52 & $40 \%$ & 64 & $49 \%$ & 15 & $11 \%$ & 4.797 & 305 & $6 \%$ & 2.235 & $47 \%$ & 2.257 & $47 \%$ & 4.492 & $94 \%$ \\
\hline 13 & R Ver Peq & 800 & 45 & $140 \%$ & 20 & $44 \%$ & 23 & $51 \%$ & 2 & $4 \%$ & 1.122 & 23 & $2 \%$ & 125 & $11 \%$ & 974 & $87 \%$ & 1.099 & $98 \%$ \\
\hline 15 & R.Carinhanha & 31.800 & 27 & $55 \%$ & 19 & $70 \%$ & 3 & $11 \%$ & 5 & $19 \%$ & 16.760 & 654 & $4 \%$ & 1.106 & $7 \%$ & 15.000 & $89 \%$ & 16.106 & $96 \%$ \\
\hline $\begin{array}{c}\text { TOTAIS } \\
\text { SF }\end{array}$ & & 137.766 & 432 & & 65 & $38 \%$ & 20 & $51 \%$ & 47 & $11 \%$ & .661 & 641 & $5 \%$ & 8.413 & $41 \%$ & 7.607 & $54 \%$ & 66.020 & $5 \%$ \\
\hline
\end{tabular}

Tabela 5.12 - Classificação dos pontos de interferência localizados nos 18 trechos de maior porte - Cenário 3

\begin{tabular}{|c|c|c|c|c|c|c|c|c|c|c|c|c|c|c|c|c|c|c|c|}
\hline $\begin{array}{c}\mathrm{N}^{0} \text { Tre- } \\
\text { cho }\end{array}$ & $\begin{array}{l}\text { Localiza- } \\
\text { ção }\end{array}$ & $\begin{array}{l}\text { Qref } \\
(1 / s)\end{array}$ & $\begin{array}{c}\text { NT to- } \\
\text { tal }\end{array}$ & $\begin{array}{l}\text { ICC } \\
(\%) \\
\end{array}$ & $\begin{array}{c}\text { N1 } \\
\text { ptos }\end{array}$ & $\% \mathrm{~N} 1$ & $\begin{array}{c}\text { N2 } \\
\text { ptos }\end{array}$ & $\begin{array}{l}\% \\
\text { N2 }\end{array}$ & $\begin{array}{l}\text { N3 } \\
\text { ptos }\end{array}$ & $\begin{array}{l}\% \\
\text { N3 }\end{array}$ & $\begin{array}{c}\text { QT } \\
(\mathbf{l} / \mathbf{s})\end{array}$ & Q1 (l/s) & $\begin{array}{r}\% \\
\text { Q1 }\end{array}$ & $\begin{array}{l}\text { Q2 } \\
(1 / s)\end{array}$ & $\begin{array}{r}\% \\
\text { Q2 } \\
\end{array}$ & $\begin{array}{l}\text { Q3 } \\
(1 / s)\end{array}$ & $\begin{array}{r}\% \\
\text { Q3 }\end{array}$ & $\begin{array}{c}\mathbf{Q}+\mathbf{Q 3} \\
(\mathrm{l} / \mathrm{s})\end{array}$ & $\begin{array}{c}\% \\
\mathrm{Q} 2+\mathrm{Q} 3 \\
\end{array}$ \\
\hline 23 & 3 Marias & 155.000 & 57 & $10,0 \%$ & 57 & $100 \%$ & 0 & $0 \%$ & 0 & $0 \%$ & 7.006 & 7.006 & $100 \%$ & 0 & $0 \%$ & 0 & 0\% & 0 & $0 \%$ \\
\hline 3 & Rio SF & 350.100 & 53 & $6,3 \%$ & 52 & $98 \%$ & 1 & $2 \%$ & 0 & $0 \%$ & 15.945 & 13.884 & $87 \%$ & 2.061 & $13 \%$ & 0 & $0 \%$ & 2.061 & $13 \%$ \\
\hline 4 & Rio SF & 396.100 & 11 & $9,7 \%$ & 11 & $100 \%$ & 0 & $0 \%$ & 0 & $0 \%$ & 2.831 & 2.831 & $100 \%$ & 0 & $0 \%$ & 0 & $0 \%$ & 0 & $0 \%$ \\
\hline 9 & Rio SF & 451.200 & 10 & $17,1 \%$ & 10 & $100 \%$ & 0 & $0 \%$ & 0 & $0 \%$ & 3.404 & 3.404 & $100 \%$ & 0 & $0 \%$ & 0 & $0 \%$ & 0 & $0 \%$ \\
\hline 11 & Rio SF & 478.900 & 60 & $37,2 \%$ & 57 & $95 \%$ & 2 & $3 \%$ & 1 & $2 \%$ & 86.777 & 11.521 & $13 \%$ & 17.383 & $20 \%$ & 57.874 & $67 \%$ & 75.257 & $87 \%$ \\
\hline 14 & Rio SF & 530.650 & 13 & $41,5 \%$ & 13 & $100 \%$ & 0 & $0 \%$ & 0 & $0 \%$ & 1.815 & 1.815 & $100 \%$ & 0 & $0 \%$ & 0 & $0 \%$ & 0 & $0 \%$ \\
\hline 16 & Rio SF & 550.100 & 22 & $43,2 \%$ & 22 & $100 \%$ & 0 & $0 \%$ & 0 & $0 \%$ & 2.449 & 2.449 & $100 \%$ & 0 & $0 \%$ & 0 & $0 \%$ & 0 & $0 \%$ \\
\hline 17 & Rio SF & 595.553 & 23 & $46,7 \%$ & 23 & $100 \%$ & 0 & $0 \%$ & 0 & $0 \%$ & 3.775 & 3.775 & $100 \%$ & 0 & $0 \%$ & 0 & $0 \%$ & 0 & $0 \%$ \\
\hline 18 & Rio SF & 622.629 & 12 & $46,8 \%$ & 12 & $100 \%$ & 0 & $0 \%$ & 0 & $0 \%$ & 2.152 & 2.152 & $100 \%$ & 0 & $0 \%$ & 0 & $0 \%$ & 0 & $0 \%$ \\
\hline 19 & Rio SF & 717.869 & 19 & $64,1 \%$ & 18 & $95 \%$ & 0 & $0 \%$ & 1 & $5 \%$ & 62.894 & 2.894 & $5 \%$ & 0 & $0 \%$ & 60.000 & $95 \%$ & 60.000 & $95 \%$ \\
\hline 20 & Sobradinho & 758.934 & 185 & $51,3 \%$ & 184 & $99 \%$ & 0 & $0 \%$ & 1 & $1 \%$ & 40.903 & 17.703 & $43 \%$ & 0 & $0 \%$ & 23.200 & $57 \%$ & 23.200 & $57 \%$ \\
\hline 21 & Rio SF & 800.000 & 282 & $19,8 \%$ & 274 & $97 \%$ & 6 & $2 \%$ & 2 & $1 \%$ & 158.123 & 21.305 & $13 \%$ & 51.874 & $33 \%$ & 84.944 & $54 \%$ & 136.819 & $87 \%$ \\
\hline 22 & Rio SF & 800.000 & 115 & $23,5 \%$ & 112 & $97 \%$ & 3 & $3 \%$ & 0 & $0 \%$ & 69.321 & 11.100 & $16 \%$ & 58.222 & $84 \%$ & 0 & $0 \%$ & 58.222 & $84 \%$ \\
\hline 23 & Itaparica & 800.000 & 345 & $21,4 \%$ & 345 & $100 \%$ & 0 & $0 \%$ & 0 & $0 \%$ & 20.493 & 20.493 & $100 \%$ & 0 & $0 \%$ & 0 & $0 \%$ & 0 & $0 \%$ \\
\hline 24 & Mox/ P. Af. & 800.000 & 36 & $10,0 \%$ & 31 & $86 \%$ & 4 & $11 \%$ & 1 & $3 \%$ & 79.067 & 8.906 & $11 \%$ & 24.328 & $31 \%$ & 45.833 & $58 \%$ & 70.161 & $89 \%$ \\
\hline 25 & Xingó & 800.000 & 15 & $1,9 \%$ & 14 & $93 \%$ & 1 & $7 \%$ & 0 & $0 \%$ & 13.373 & 3.563 & $27 \%$ & 9.810 & $73 \%$ & 0 & $0 \%$ & 9.810 & $73 \%$ \\
\hline 26 & Rio SF & 800.000 & 14 & $3,3 \%$ & 13 & $93 \%$ & 1 & $7 \%$ & 0 & $\mathbf{0 \%}$ & 5.487 & 771 & $14 \%$ & 4.716 & $86 \%$ & 0 & $0 \%$ & 4.716 & $86 \%$ \\
\hline 27 & Rio SF & 800.000 & 56 & $10,1 \%$ & 52 & $93 \%$ & 4 & $7 \%$ & 0 & $0 \%$ & 55.143 & 23.250 & $42 \%$ & 31.893 & $58 \%$ & 0 & $0 \%$ & \begin{tabular}{|l|}
31.893 \\
\end{tabular} & $58 \%$ \\
\hline $\begin{array}{c}\text { TOTAIS } \\
\text { SF }\end{array}$ & & & 1.328 & & 1.300 & $98 \%$ & 22 & $2 \%$ & 6 & $0 \%$ & 630.960 & 158.822 & $25 \%$ & 200.287 & $32 \%$ & 271.852 & $43 \%$ & 472.138 & $75 \%$ \\
\hline
\end{tabular}


Utilizando valores relativos intermediários, verifica-se nos trechos de menor porte (Tabela 5.11) que o número de vazões outorgadas no estágio 3 (avançado) chega a 11\% (N3 = 0,11NT), com 47 dos 432 pontos classificados neste nível de maior exigência, valor este um pouco superior ao previsto no $3^{\circ}$ Indicador $(\mathrm{N} 3 \leq 0,10 \mathrm{NT})$. Em termos de vazões, tem-se $54 \%$ das vazões outorgadas no nível $3(\mathrm{Q} 3=0,54 \mathrm{QT})$, atendendo ao $2^{\circ}$ indicador (Q3 $\geq 0,4 Q T)$ e $95 \%$ das vazões nos níveis 2 e 3, atendendo ao $1^{\circ}$ indicador $(\mathrm{Q} 2+\mathrm{Q} 3 \geq 0,8 \mathrm{QT})$.

Já nos trechos de maior porte, o número de vazões outorgadas e classificadas no $3^{\circ}$ estágio (N3) continuam insignificantes em relação ao total, sendo 6 pontos em 1328. Mesmo assim, de forma geral, estas vazões representam $43 \%$ do volume total outorgado $(\mathrm{Q} 3=0,43 \mathrm{QT})$, atendendo ao $2^{\circ}$ indicador $(\mathrm{Q} 3 \geq 0,4 \mathrm{QT})$ e as vazões classificadas nos níveis 2 e 3 representam $75 \%$ do volume total $(\mathrm{Q} 2+\mathrm{Q} 3=0,75 \mathrm{QT})$, valor pouco inferior ao $1^{\circ}$ indicador $(\mathrm{Q} 2+\mathrm{Q} 3 \geq 0,8 \mathrm{QT})$.

\subsubsection{Cenário 4 - Final: índices relativos intermediários, com índices absolutos}

Neste Cenário 4 mantém-se os mesmos valores para os índices relativos do Cenário 3, acrescentando agora os índices absolutos de mínimo e máximo descritos no item 4.6.1. Dessa forma, independente do trecho, onde $\mathrm{Q}_{\text {demanda }}<10$ 1/s, classifica-se automaticamente a vazão outorgada no Estágio 1 - Simplificado (índice absoluto mínimo); por outro lado, sendo $\mathrm{Q}_{\mathrm{de}}$ manda $>5001 /$ s, a vazão outorgada é classificada automaticamente no Estágio 3 - Monitoramento Avançado, com instalação de equipamento de medição, independente das condições locais (índice absoluto máximo).

Os resultados dos cálculos para o Cenário 4 são apresentados nas tabelas 5.13 e 5.14 a seguir: 
Tabela 5.13 - Classificação dos pontos de interferência localizados nos 9 trechos de menor porte - Cenário 4

\begin{tabular}{|c|c|c|c|c|c|c|c|c|c|c|c|c|c|c|c|c|c|c|c|}
\hline $\begin{array}{l}N^{\circ} \text { Tre- } \\
\text { cho }\end{array}$ & $\begin{array}{l}\text { Localiza- } \\
\text { ção }\end{array}$ & $\begin{array}{l}\text { Qref } \\
(\mathbf{l} / \mathbf{s})\end{array}$ & $\begin{array}{c}\text { NT to- } \\
\text { tal }\end{array}$ & $\begin{array}{l}\text { ICC } \\
(\%)\end{array}$ & $\begin{array}{c}\text { N1 } \\
\text { ptos }\end{array}$ & $\begin{array}{l}\% \\
\text { N1 }\end{array}$ & $\begin{array}{c}\text { N2 } \\
\text { ptos }\end{array}$ & $\begin{array}{c}\% \\
\text { N2 }\end{array}$ & $\begin{array}{c}\text { N3 } \\
\text { ptos }\end{array}$ & $\begin{array}{c}\% \\
\text { N3 }\end{array}$ & QT (l/s) & Q1 (l/s) & $\begin{array}{r}\% \\
\text { Q1 }\end{array}$ & Q2 (l/s) & $\begin{array}{r}\% \\
\text { Q2 }\end{array}$ & Q3 $(1 / \mathbf{s})$ & $\begin{array}{r}\% \\
\text { Q3 }\end{array}$ & $\begin{array}{c}\text { Q2+Q3 } \\
(\mathbf{l} / \mathbf{s})\end{array}$ & $\begin{array}{c}\% \\
\mathrm{Q} 2+\mathrm{Q} 3\end{array}$ \\
\hline 1 & Nasc. R SF & 21.641 & 29 & $31 \%$ & 18 & $62 \%$ & 11 & $38 \%$ & 0 & $0 \%$ & 4.141 & 701 & $17 \%$ & 3.440 & $83 \%$ & 0 & $0 \%$ & 3.440 & $83 \%$ \\
\hline 5 & R. Bezerra & 4.000 & 23 & $88 \%$ & 2 & $9 \%$ & 11 & $48 \%$ & 10 & $43 \%$ & 3.312 & 11 & $0 \%$ & 780 & $24 \%$ & 2.521 & $76 \%$ & 3.301 & $100 \%$ \\
\hline 6 & Res.Queim. & 20.000 & 43 & $53 \%$ & 12 & $28 \%$ & 29 & $67 \%$ & 2 & $5 \%$ & 6.257 & 457 & $7 \%$ & 4.593 & $73 \%$ & 1.208 & $19 \%$ & 5.800 & $93 \%$ \\
\hline 7 & Rio Preto & 11.225 & 38 & $42 \%$ & 21 & $55 \%$ & 15 & $39 \%$ & 2 & $5 \%$ & 4.544 & 771 & $17 \%$ & 1.869 & $41 \%$ & 1.904 & $42 \%$ & 3.773 & $83 \%$ \\
\hline 8 & Rio Preto & 18.600 & 42 & $91 \%$ & 6 & $14 \%$ & 28 & $67 \%$ & 8 & $19 \%$ & 12.368 & 252 & $2 \%$ & 4.450 & $36 \%$ & 7.667 & $62 \%$ & 12.117 & $98 \%$ \\
\hline 10 & R. Urucuia & 26.400 & 54 & $62 \%$ & 15 & $28 \%$ & 29 & $54 \%$ & 10 & $19 \%$ & 16.360 & 468 & $3 \%$ & 5.956 & $36 \%$ & 9.937 & $61 \%$ & 15.893 & $97 \%$ \\
\hline 12 & R.Ver Gde & 3.300 & 131 & $145 \%$ & 52 & $40 \%$ & 64 & $49 \%$ & 15 & $11 \%$ & 4.797 & 305 & $6 \%$ & 2.235 & $47 \%$ & 2.257 & $47 \%$ & 4.492 & $94 \%$ \\
\hline 13 & R Ver Peq & 800 & 45 & $140 \%$ & 42 & $93 \%$ & 1 & $2 \%$ & 2 & $4 \%$ & 1.122 & 136 & $12 \%$ & 12 & $1 \%$ & 974 & $87 \%$ & 986 & $88 \%$ \\
\hline 15 & R.Carinhanha & 31.800 & 27 & $55 \%$ & 19 & $70 \%$ & 2 & $7 \%$ & 6 & $22 \%$ & 16.760 & 654 & $4 \%$ & 522 & $3 \%$ & 15.583 & $93 \%$ & 16.106 & $96 \%$ \\
\hline $\begin{array}{c}\text { TOTAIS } \\
\text { SF }\end{array}$ & & 137.766 & 432 & & 87 & $43 \%$ & 190 & $44 \%$ & 55 & $13 \%$ & 9.661 & 3.754 & $5 \%$ & 3.857 & $34 \%$ & 42.049 & $60 \%$ & 65.907 & $95 \%$ \\
\hline
\end{tabular}

Tabela 5.14 - Classificação dos pontos de interferência localizados nos 18 trechos de maior porte - Cenário 4

\begin{tabular}{|c|c|c|c|c|c|c|c|c|c|c|c|c|c|c|c|c|c|c|c|}
\hline $\begin{array}{c}\mathbf{N}^{0} \text { Tre- } \\
\text { cho }\end{array}$ & $\begin{array}{l}\text { Localiza- } \\
\text { ção }\end{array}$ & $\begin{array}{l}\text { Qref } \\
(1 / s)\end{array}$ & $\begin{array}{c}\text { NT to- } \\
\text { tal }\end{array}$ & $\begin{array}{l}\text { ICC } \\
(\%)\end{array}$ & $\begin{array}{c}\text { N1 } \\
\text { ptos }\end{array}$ & $\% \mathrm{~N} 1$ & $\begin{array}{c}\text { N2 } \\
\text { ptos }\end{array}$ & $\begin{array}{l}\% \\
\mathrm{~N} 2\end{array}$ & $\begin{array}{c}\text { N3 } \\
\text { ptos }\end{array}$ & $\begin{array}{c}\% \\
\text { N3 }\end{array}$ & $\begin{array}{l}\text { QT } \\
(1 / s)\end{array}$ & Q1 (l/s) & $\begin{array}{r}\% \\
\text { Q1 } \\
\end{array}$ & $\begin{array}{c}\mathbf{Q} 2 \\
(\mathbf{l} / \mathbf{s})\end{array}$ & $\begin{array}{r}\% \\
\text { Q2 } \\
\end{array}$ & $\begin{array}{c}\text { Q3 } \\
(1 / s)\end{array}$ & $\begin{array}{r}\% \\
\text { Q3 }\end{array}$ & \begin{tabular}{|c|}
$\mathbf{Q} 2+\mathbf{Q 3}$ \\
$(\mathbf{l} / \mathbf{s})$ \\
\end{tabular} & $\begin{array}{c}\% \\
\mathrm{Q} 2+\mathrm{Q} 3 \\
\end{array}$ \\
\hline 2 & 3 Marias & 155.000 & 57 & $10,0 \%$ & 56 & $98 \%$ & 0 & $0 \%$ & 1 & $2 \%$ & 7.006 & 6.421 & $92 \%$ & 0 & $0 \%$ & 586 & $8 \%$ & 586 & $8 \%$ \\
\hline 3 & Rio SF & 350.100 & 53 & $6,3 \%$ & 40 & $75 \%$ & 0 & $0 \%$ & 13 & $25 \%$ & 15.945 & 4.416 & $28 \%$ & 0 & $0 \%$ & 11.530 & $72 \%$ & 11.530 & $72 \%$ \\
\hline 4 & Rio SF & 396.100 & 11 & $9,7 \%$ & 9 & $82 \%$ & 0 & $0 \%$ & 2 & $18 \%$ & 2.831 & 1.304 & $46 \%$ & 0 & $0 \%$ & 1.527 & $54 \%$ & 1.527 & $54 \%$ \\
\hline 9 & Rio SF & 451.200 & 10 & $17,1 \%$ & 9 & $90 \%$ & 0 & $0 \%$ & 1 & $10 \%$ & 3.404 & 1.327 & $39 \%$ & 0 & $0 \%$ & 2.076 & $61 \%$ & 2.076 & $61 \%$ \\
\hline 11 & Rio SF & 478.900 & 60 & $37,2 \%$ & 50 & $83 \%$ & 0 & $0 \%$ & 10 & $17 \%$ & 86.777 & 3.996 & $5 \%$ & 0 & $0 \%$ & 82.781 & $95 \%$ & 82.781 & $95 \%$ \\
\hline 14 & Rio SF & 530.650 & 13 & $41,5 \%$ & 11 & $85 \%$ & 0 & $0 \%$ & 2 & $15 \%$ & 1.815 & 300 & $17 \%$ & 0 & $0 \%$ & 1.515 & $83 \%$ & 1.515 & $83 \%$ \\
\hline 16 & Rio SF & 550.100 & 22 & $43,2 \%$ & 22 & $100 \%$ & 0 & $0 \%$ & 0 & $0 \%$ & 2.449 & 2.449 & $100 \%$ & 0 & $0 \%$ & 0 & $0 \%$ & 0 & $0 \%$ \\
\hline 17 & Rio SF & 595.553 & 23 & $46,7 \%$ & 21 & $91 \%$ & 0 & $0 \%$ & 2 & $9 \%$ & 3.775 & 1.244 & $33 \%$ & 0 & $0 \%$ & 2.531 & $67 \%$ & 2.531 & $67 \%$ \\
\hline 18 & Rio SF & 622.629 & 12 & $46,8 \%$ & 11 & $92 \%$ & 0 & $0 \%$ & 1 & $8 \%$ & 2.152 & 1.409 & $65 \%$ & 0 & $0 \%$ & 743 & $35 \%$ & 743 & $35 \%$ \\
\hline 19 & Rio SF & 717.869 & 19 & $64,1 \%$ & 17 & $89 \%$ & 0 & $0 \%$ & 2 & $11 \%$ & 62.894 & 2.006 & $3 \%$ & 0 & $0 \%$ & 60.889 & $97 \%$ & 60.889 & $97 \%$ \\
\hline 20 & Sobradinho & 758.934 & 185 & $51,3 \%$ & 176 & $95 \%$ & 1 & $1 \%$ & 8 & $4 \%$ & 40.903 & 11.048 & $27 \%$ & 500 & $1 \%$ & 29.355 & $72 \%$ & 29.855 & $73 \%$ \\
\hline 21 & Rio SF & 800.000 & 282 & $19,8 \%$ & 267 & $95 \%$ & 0 & $0 \%$ & 15 & $5 \%$ & 158.123 & 15.535 & $10 \%$ & 0 & $0 \%$ & 142.588 & $90 \%$ & 142.588 & $90 \%$ \\
\hline 22 & Rio SF & 800.000 & 115 & $23,5 \%$ & 108 & $94 \%$ & 0 & $0 \%$ & 7 & $6 \%$ & 69.321 & 5.351 & $8 \%$ & 0 & $0 \%$ & 63.971 & $92 \%$ & 63.971 & $92 \%$ \\
\hline 23 & Itaparica & 800.000 & 345 & $21,4 \%$ & 341 & $99 \%$ & 0 & $0 \%$ & 4 & $1 \%$ & 20.493 & 11.543 & $56 \%$ & 0 & $0 \%$ & 8.950 & $44 \%$ & 8.950 & $44 \%$ \\
\hline 24 & Mox/ P. Af. & 800.000 & 36 & $10,0 \%$ & 27 & $75 \%$ & 0 & $0 \%$ & 9 & $25 \%$ & 79.067 & 852 & $1 \%$ & 0 & $0 \%$ & 78.215 & $99 \%$ & 78.215 & $99 \%$ \\
\hline 25 & Xingó & 800.000 & 15 & $1,9 \%$ & 13 & $87 \%$ & 0 & $0 \%$ & 2 & $13 \%$ & 13.373 & 521 & $4 \%$ & 0 & $0 \%$ & 12.853 & $96 \%$ & 12.853 & $96 \%$ \\
\hline 26 & Rio SF & 800.000 & 14 & $3,3 \%$ & 13 & $93 \%$ & 0 & $0 \%$ & 1 & $7 \%$ & 5.487 & 771 & $14 \%$ & 0 & $0 \%$ & 4.716 & $86 \%$ & 4.716 & $86 \%$ \\
\hline 27 & Rio SF & 800.000 & 56 & $10,1 \%$ & 38 & $68 \%$ & 0 & $0 \%$ & 18 & $32 \%$ & 55.143 & 3.949 & $7 \%$ & 0 & $0 \%$ & 51.193 & $93 \%$ & 51.193 & $93 \%$ \\
\hline $\begin{array}{c}\text { TOTAIS } \\
\text { SF } \\
\end{array}$ & & & 1.328 & & 1.229 & $93 \%$ & 1 & $0 \%$ & 98 & $7 \%$ & 630.960 & 74.443 & $12 \%$ & 500 & $0 \%$ & 556.018 & $88 \%$ & 556.518 & $88 \%$ \\
\hline
\end{tabular}


Em termos de números de pontos de vazões outorgadas classificadas em cada um dos três níveis, podem-se resumir os dados acima na seguinte tabela:

Tabela 5.15 - Distribuição do número de pontos de interferência nos três estágios de exigência quanto ao monitoramento - Cenário 4

\begin{tabular}{|c|c|c|c|c|c|c|c|}
\hline Porte & $\begin{array}{l}\mathrm{N}^{0} \text { ptos } \\
\text { outor- } \\
\text { gados }\end{array}$ & $\begin{array}{c}\mathbf{N 1}-\mathbf{N}^{\circ} \text { ptos } \\
\text { Estágio1 } \\
\text { (Simplificado) }\end{array}$ & $\% \mathrm{~N} 1$ & $\begin{array}{c}\text { N2 - No ptos Es- } \\
\text { tágio2 } \\
\text { (Intermediário) }\end{array}$ & $\begin{array}{c}\% \\
\mathrm{~N} 2\end{array}$ & $\begin{array}{l}\text { N3 - No ptos } \\
\text { Estágio3 } \\
\text { (Avançado) }\end{array}$ & $\begin{array}{c}\% \mathrm{N3} \\
\text { Ind. } \\
\text { Geral } 3\end{array}$ \\
\hline $\begin{array}{l}\text { Menor Porte } \\
\text { (Afluentes) }\end{array}$ & 432 & 187 & $43 \%$ & 190 & $44 \%$ & 55 & $13 \%$ \\
\hline $\begin{array}{l}\text { Maior Porte (rio } \\
\text { SF e reservatórios) }\end{array}$ & 1.328 & 1.229 & $93 \%$ & 1 & $0 \%$ & 98 & $7 \%$ \\
\hline $\begin{array}{c}\text { TOTAL } \\
\text { BACIA SF }\end{array}$ & 1.760 & 1.416 & $80 \%$ & 191 & $11 \%$ & 153 & $9 \%$ \\
\hline
\end{tabular}

Em termos da distribuição dos pontos em toda a bacia do SF, o Indicador Geral 3 é atendido, somando 153 (N3) o total de pontos classificados no estágio 3 (instalação de equipamento), correspondente a 9\% do total de 1.760 (NT) pontos outorgados nos trechos analisados, ou seja, N3 $\leq 0,1$ NT.

Entretanto, ao verificarmos os rios de distribuição com menor porte - afluentes do rio São Francisco, observa-se que o número de vazões outorgadas classificadas como Estágio 3 é bem superior, em termos percentuais, sendo que 55 dos 432 pontos (13\%) desses trechos foram classificados neste nível, sendo este índice superior ao Indicador 3.

Observa-se também que há somente uma vazão outorgada classificada como nível 2 - Intermediário entre todas as 1328 vazões localizadas nos trechos de maior porte. Isso porque foi criado índice absoluto máximo prevendo somente classificação direta para o estágio 3 Avançado, e deixou-se para classificação no nível 2 somente para os índices relativos. Como esses trechos de maior porte tem mais disponibilidade hídrica, então a maioria das vazões possuem Comprometimento Individual pouco significativo, e relação $\mathrm{Q}_{\text {demanda }} / \mathrm{Q}_{\text {referencia }}$ classificou a maioria das vazões (1229 em 1328, ou seja, 93\%) como nível 1 - Monitoramento Simplificado.

Em termos de vazão outorgada, podem-se resumir os dados das tabelas 5.13 e 5.14 do Cenário 4 na tabela 5.16 a seguir: 
Tabela 5.16 - Distribuição das vazões outorgadas nos três estágios de exigência quanto ao monitoramento - Cenário 4

\begin{tabular}{|c|c|c|c|c|c|c|c|c|c|}
\hline Porte & $\begin{array}{c}\text { QT - Vazão } \\
\text { Total Ou- } \\
\text { torgada }\end{array}$ & $\begin{array}{c}\text { Q1 - Vazão } \\
\text { Estágio1 } \\
\text { (Simplif) }\end{array}$ & $\%$ Q1 & $\begin{array}{c}\text { Q2 - Vazão } \\
\text { Estágio2 } \\
\text { (Interme- } \\
\text { diário) }\end{array}$ & $\% Q_{2}$ & \begin{tabular}{|c|} 
Q3 -Vazão \\
Estágio3 \\
(Avan- \\
çado)
\end{tabular} & $\mid \begin{array}{c}\% \text { Q3 - In- } \\
\text { dicador } \\
\text { Geral } 2\end{array}$ & $\mathbf{Q} 2+\mathbf{Q 3}$ & $\begin{array}{c}\text { \%Q2+Q3 - } \\
\text { Indicador } \\
\text { Geral } 1\end{array}$ \\
\hline Porte & 69.661 & 3.754 & $5 \%$ & 23.857 & $34 \%$ & 42.049 & $60 \%$ & 65.907 & $95 \%$ \\
\hline $\begin{array}{r}\text { Maior } \\
\text { Porte }\end{array}$ & 30.960 & .443 & $12 \%$ & 500 & $0 \%$ & 556.018 & $88 \%$ & 556.518 & $88 \%$ \\
\hline $\begin{array}{r}\text { TOTAL } \\
\text { ACIA SF }\end{array}$ & 0.621 & .197 & $11 \%$ & 24.357 & $3 \%$ & 8.067 & $85 \%$ & 622.424 & $89 \%$ \\
\hline
\end{tabular}

Pelas vazões outorgadas, tanto o $1^{\circ}$ Indicador - Controle objetivo do monitoramento $(\mathrm{Q} 2+$ Q3 $\geq 0,8 \times$ Qtotal), quanto o $2^{\circ}$ Indicador - Verificação do real uso outorgado (Q3 $\geq 0,4 \times$ Qtotal) são atendidos, pois Q3 = 0,80xQT e Q2 + Q3 = 0,89xQT. Esses resultados são atendidos em toda a bacia, e também em separado, nos trechos de menor porte e nos de maior porte.

Cabe aqui observar, no entanto, que em termos de vazão outorgada, a classificação final deste Cenário 4, em termos de número de pontos e de volume outorgado, que 153 pontos foram classificados no $3^{\circ}$ estágio (Monitoramento Avançado) e que esses números correspondem à $85 \%$ do volume total outorgado. Ou seja, em termos gerais, uma minoria de usuários (9\% do total) é responsável pela maioria do volume outorgado.

E essa proporção é diferenciada nos trechos de menor porte e de maior porte. Nos trechos de menor porte, $13 \%$ dos usuários tipo N3 são responsáveis por $60 \%$ da vazão outorgada a ser monitorada por equipamentos (Q3). Já nas regiões onde os portes são maiores, na calha do São Francisco e nos reservatórios ao longo do rio, contendo perímetros de irrigação da CODEVASF, da CHESF e a Transposição do rio São Francisco, 7\% do número de usuários classificados no $3^{\circ}$ estágio (N3) são responsáveis por $88 \%$ da vazão com monitoramento de maior controle, do tipo Q3.

A seguir, apresenta-se uma discussão dos resultados de forma mais detalhada, levando em conta a distribuição das vazões outorgadas num dos três níveis de monitoramento para os 27 trechos da bacia do São Francisco, com ênfase na referida classificação em alguns trechos da bacia. 


\subsubsection{Discussão dos resultados do estudo de caso}

Pelos resultados obtidos nos quatro cenários anteriores, podem-se tecer algumas observações gerais:

\subsubsection{Quanto aos índices relativos}

Os índices relativos (PCC, P1CI1, P1CI2, P2CI1 e P2CI2) mais restritivos promovem um peso maior ao Comportamento Individual e Coletivo de um ponto de interferência no trecho onde está localizado, de forma a classificá-los em níveis de monitoramento mais exigentes (2 - instalação de horímetro ou 3 - de equipamento), tal como apresentado no Cenário 1. Como são índices relativos, em locais com vazão de referência menor, ou seja, em rios de menor porte, classificam os pontos de forma excessiva nos estágios 2 e 3 , ou seja, torna importante quanto à exigência de monitoramento, de forma a classificar a maioria das vazões outorgadas nesses estágios. Já em trechos de maior porte, onde a vazão de referência é maior, classifica os pontos de interferência de forma mais adequada, de forma atender aos três indicadores gerais previamente estipulados: $1^{\circ}$ Indicador $(\mathrm{Q} 2+\mathrm{Q} 3 \geq 0,8 \times \mathrm{Q}$ total $), 2^{\circ}$ Indicador (Q3 $\geq 0,4 \times \mathrm{Qtotal}), 3^{\circ}$ Indicador $(\mathrm{N} 3 \leq 0,1 \times$ Ntotal). No entanto, nesses trechos de maior porte, apesar de as vazões classificadas no $3^{\circ}$ nível representarem um percentual significativo em termos de volume $(\mathrm{Q} 3=63 \%$ de $\mathrm{QT})$, somente 14 das 1328 vazões $(\mathrm{N} 3=1 \%$ de NT) foram distribuídas nesse $3^{\circ}$ nível;

Já os índices relativos (PCC, P1CI1, P1CI2, P2CI1 e P2CI2) menos restritivos fazem com que o ponto de interferência no trecho seja menos influente para classificação em estágios de exigência maiores, no que diz respeito ao Comportamento Individual e Coletivo do referido ponto. Pelo Cenário 2, verificou-se que, em trechos de menor porte, os índices relativos promoveram uma classificação dos pontos de interferência de forma mais adequada, de forma atender aos três indicadores gerais e a não criar um excessivo número de pontos no estágio 3 (instalação de equipamento). Já nos trechos de maior porte, com vazões de referência menores, quase todos os pontos foram classificados no estágio 1 (monitoramento simplificado), de formal tal que, quase não havendo pontos nos estágios 2 e 3 , o $1^{\circ}$ Indicador $(\mathrm{Q} 2+\mathrm{Q} 3 \geq 0,8 \times \mathrm{Qtotal})$ e $2^{\circ}$ Indicador (Q3 $\geq 0,4 \times$ Qtotal) não puderam ser atendidos; 
Quanto aos índices relativos (PCC, P1CI1, P1CI2, P2CI1 e P2CI2) com valores intermediários, melhoram a distribuição na classificação das vazões outorgadas de uma forma geral, tanto nos trechos de menor porte quanto no de maior porte, atendendo à maioria dos indicadores gerais. Entretanto, continuam a classificar as vazões outorgadas em níveis de exigência superiores ( 2 e 3) para os trechos de menor porte e no nível 1 (simplificado) para os trechos de maior porte.

\subsubsection{Quanto aos índices absolutos}

Pelo observado no Cenário 4, a inclusão de índice absoluto mínimo (Qdemanda $<10$ 1/s $\rightarrow$ Estágio 1 - Simplificado) promoveu alteração somente no trecho 13 - rio Verde Pequeno, que possui 45 vazões outorgadas, das quais 22 outorgas são menores que 10 1/s, passando do Estágio 2 (Intermediário) para o Estágio 1 (Simplificado). Em termos de controle do volume outorgado, não houve alteração significativa, uma vez que as 4 maiores vazões outorgadas para este trecho, que correspondem a $87 \%$ do volume outorgado, continuaram classificadas como nível 3 - Avançado. Ou seja, o índice absoluto mínimo serviu para simplificar as exigências de monitoramento de alguns usuários e somente num trecho.

Já a inclusão de índice absoluto máximo (Qdemanda $>500$ 1/s $\rightarrow$ Estágio 3 - Avançado) serviu para classificar diversas outorgas no nível 3, com exigência de instalação de equipamentos, e que antes estavam simplesmente no nível 1, principalmente nos trechos de maior porte. Exemplo disso é a captação da Companhia Pernambucana de Saneamento - Compesa, no município de Petrolina/PE, localizada no trecho 21 - rio São Francisco, a jusante da barragem de Sobradinho, com Qdemanda $=780$ 1/s. Em termos de comprometimento individual no trecho, tem-se que ICImáx $=0,1 \%$, classificando cem termos relativos como nível 1 . No entanto, trata-se de um empreendimento porte considerável, responsável pelo abastecimento de água de todo o munício de Petrolina/PE, e é razoável a exigência de um monitoramento avançado a um empreendimento outorgado deste porte, independentemente de sua localização.

Com o resultado da inclusão do índice absoluto máximo, 91 outorgas classificadas nos níveis 1 e 2, localizadas nos trechos de maior porte, foram automaticamente classificadas como nível 3. Porém, nesses 18 trechos de maior porte, somente 1 usuário dos 1328 ficou como 
classificação final no nível 2. Assim que a distribuição final deveria revista, com a possibilidade de, por exemplo, criar um índice absoluto máximo para classificação direta para o nível 2 (intermediário), senão não faz sentido criar 3 níveis de exigência.

\subsubsection{Quanto ao estabelecimento de valores únicos dos índices absolutos e relativos}

Em termos gerais, o melhor cenário que representa valores fixos para os índices absolutos e relativos é o Cenário 4. Entretanto, para este Cenário, se forem analisados cada trecho em específico, constatam-se diversas distorções, sendo exemplificadas duas, uma num trecho de menor porte, e outra num trecho de maior porte, a seguir:

- No rio Bezerra (trecho 5), das 23 vazões outorgadas, 10 (43\%) foram classificadas no nível 3, e todas estas vazões possuem Q Qemanda acima de 200 1/s, e correspondem a $73 \%$ do volume outorgado. Tomando somente 4 das maiores vazões outorgadas ( $18 \%$ do total), teria se alcançaria $40 \%$ do volume outorgado (Indicador 3 - verificação do real uso outorgado);

- No trecho 16, calha do rio São Francisco, da confluência com o rio Carinhanha até a confluência com o rio Corrente, todas as 22 vazões outorgadas foram classificadas como nível 1 - Monitoramento Simplificado, ou seja, não se distribuiu neste trecho nenhuma vazão para os níveis 2 e 3 . Neste trecho, existem 3 vazões com $Q_{\text {demanda }}$ próximos de 450 1/s que, somados, possuem 57\% do volume total outorgado no trecho. Como são vazões de demanda inferiores a 500 1/s, foram classificadas como nível 1.

Resumindo, verifica-se pelos trechos de domínio da União da bacia do São Francisco, objetos do presente estudo de caso, diversas disponibilidades hídricas, além da variabilidade das 1328 vazões outorgadas em termos de parâmetros outorgados. Dessa forma, por mais que se tente reajustar valores numéricos para os índices absolutos e relativos, não se chega a uma classificação satisfatória num dos três níveis de monitoramento criados (simplificado, intermediário e avançado) para todos os trechos ao mesmo tempo. 
Entretanto, para maioria das vazões outorgadas na bacia do São Francisco, os valores dos índices absolutos e relativos do Cenário 4 foram capazes, em linhas gerais, de apresentar uma classificação adequada no que tange aos três níveis de monitoramento. Adota-se, então, os valores dos índices relativos e absolutos do Cenário 4 para realização da classificação das vazões outorgadas no São Francisco num dos três níveis de monitoramento, valores estes apresentados a seguir:

- Índices relativos: PCC=0,5 (50\%); P1CI1 = 0,005 (0,5\%); P1CI2 = 0,05 (5\%); $\mathrm{P} 2 \mathrm{CI} 1=0,003(0,3 \%) ; \mathrm{P} 2 \mathrm{CI}=0,03(3 \%)$.

- Índices absolutos: $\mathrm{QAB} 1=10 \mathrm{l} / \mathrm{s} ; \mathrm{QAB} 2=500 \mathrm{l} / \mathrm{s}$

\subsection{FLUXOGRAMA PARA POSSIbILITAR CONSTRUÇÃO DE SSD PARA CONTROLE DAS VAZÕES OUTORGADAS}

Como trabalho consolidado da presente dissertação, apresenta-se a seguir um fluxograma detalhado, que servirá de base para criação de programa computacional de SSD para controle de vazões de domínio da União outorgadas na bacia do São Francisco.

Para chegar à montagem desse fluxograma, utilizaram-se os resultados dos índices absolutos (QAB1 e QAB2) e dos índices relativos (PCC, P1CI1, P1CI2, P2CI1 e P2CI2) encontrados no estudo de caso da bacia do São Francisco, além dos resultados sobre os equipamentos de medição de vazão, constantes dos Apêndices C e D.

O fluxograma representa um subsistema do Sistema de Controle de Balanço Hídrico (SCBH), elaborado por Collischonn (2014), específico para outorgas de domínio da União da bacia do São Francisco. A escolha de um "módulo auxiliar" ao SCBH se dá pelo fato de esse sistema ser elaborado por bacia, cada uma dividida em trechos, contendo Indicadores de Comprometimento Individual e Coletivo, tal qual foi desenvolvido neste trabalho.

Além disso, o SCBH é um sistema de apoio a decisão de outorga em rios federais utilizado para outras bacias, além da do São Francisco: Paraná, Piranhas-Açu, Paraíba do Sul, Tocantins, Doce e Uruguai. Além desses rios, o sistema abrange toda a bacia (rios federais e estaduais) do rio São Marcos (DF/GO/MG), do rio Preto (DF/GO/MG), e do Itapecuru (MA). 
Encontrando resultados numéricos dos índices absolutos e relativos para outras bacias, o fluxograma a seguir apresentado pode ser adaptado para as duas versões do SCBH: tanto para a versão local, desenvolvida em Matlab, que funciona em computadores individuais ou em grupos de computadores conectados a um mesmo servidor institucional, como para a versão Web, desenvolvida em linguagem PHP com banco de dados SQL Server. Isso porque a entrada de dados e a resposta de saída das duas versões são idênticas, e o que diferencia uma versão está na parte da inteligência geográfica e na forma de acumulação das demandas (Collischonn, 2014), mas que não afeta na utilização de cada uma das versões como base para o SSD proposto na presente dissertação.

Segue representação gráfica do fluxograma 1 - extensão do SCBH para as outorgas de domínio da União da bacia do São Francisco, seguido dos dados de entrada, dos cálculos a serem feitos e das respostas a serem fornecidas como subsídio para decisão de enquadramento do ponto de interferência num dos três estágios pré-determinados: simplificado, intermediário e avançado: 


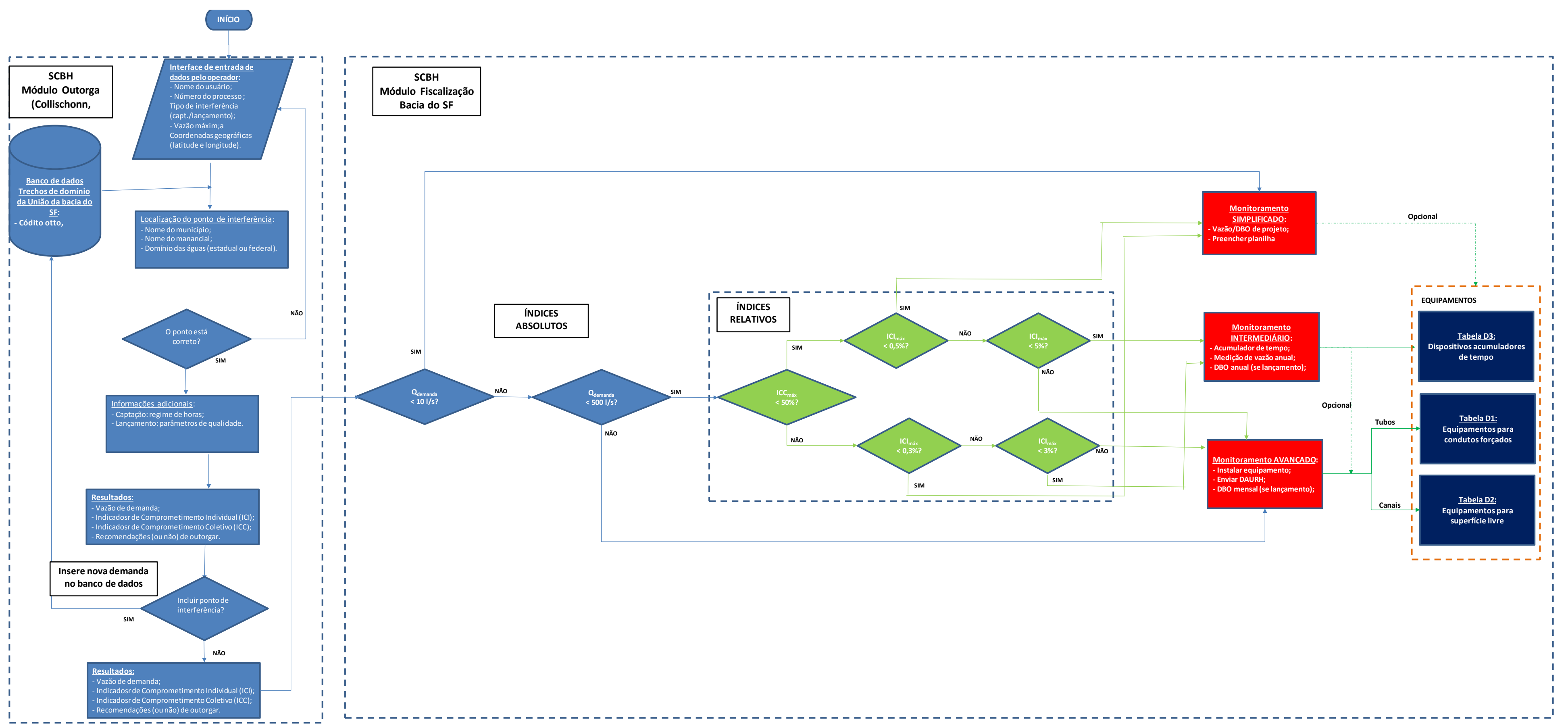

Figura 5.9 - Fluxograma do SSD para classificação das outorgas de domínio da União da bacia do rio São Francisco 
Em linhas gerais, o subsistema auxiliar ao SCBH pode ser entendido como um "módulo de fiscalização" complementar. Busca-se, com o novo "SCBH-fiscalização", a continuidade no que tange de suporte à decisão para análise de outorgas nas bacias onde está implementado, com o acréscimo de servir de apoio ao controle dos usuários outorgados, classificando os pontos de interferência nos três estágios gradativos criados: monitoramento simplificado, monitoramento intermediário ou monitoramento avançado, com instalação de equipamento.

A seguir, apresenta-se um passo-a-passo do funcionamento do programa, dividido em duas partes: a do SCBH normal, e a módulo adicional ou "SCBH fiscalização/".

\section{1) SCBH Normal}

Passo 1 - Dados de entrada do usuário: inicialmente, são inseridos os dados de entrada requeridos pelo SCBH.

- Nome do usuário;

- Número do processo (opcional);

- Tipo de interferência (captação ou lançamento);

- Vazão máxima e regime de operação ( $n^{\circ}$ de horas/dia e $n^{\circ}$ de dias/mês);

- Coordenadas geográficas da interferência (latitude e longitude).

Passo 2 - Divisão da bacia em trechos e dados de disponibilidade hídrica: a partir dos dados iniciais de localização do usuário, o SCBH acessa o banco de dados por bacia (no caso, da bacia do SF) e identifica, pelas coordenadas geográficas, o trecho onde está situado o ponto de interferência, sendo este ottocodificado, conforme explanado no item 3.4.2 do presente trabalho. Obtém-se, então, as seguintes informações do trecho, para confirmação:

- Município em que se localiza o ponto de interferência;

- Nome do manancial;

- Domínio das águas (se estadual ou federal).

Não sendo essas as informações, o sistema requer que sejam alteradas as coordenadas geográficas e volta-se ao início do passo 2.

Passo 3 - Informações adicionais do ponto de interferência: o SCBH requer informações complementares a respeito do ponto de interferência, dividindo em dois tipos:

Se o ponto for de captação: 
- Valores mensais de vazão máxima, $\mathrm{n}^{\circ}$ de horas por dia e $\mathrm{n}^{\circ}$ dias de mês;

- Regime de vazões: máx. instantânea, média diária, média mensal, média anual.

Se o ponto for de lançamento:

- Repete a vazão máxima e regime de operação ( $n^{\circ}$ de horas/dia e $n^{\circ}$ de dias/mês) do Passo 1 e o usuário pode alterar;

- Parâmetros de qualidade da água do efluente: Temperatura $\left({ }^{\circ} \mathrm{C}\right), \mathrm{DBO}(\mathrm{mg} / \mathrm{l})$, Nitrogênio Total (mg/l) e Fósforo Total (mg/l).

- Regime de vazões: máx. instantânea, média diária, média mensal, média anual.

Passo 4 - Cálculo dos Indicadores de Comprometimento Individual (ICI) e Coletivo (ICC): o sistema calcula os indicadores e informa se o pleito de outorga pode ou não ser atendido, de acordo com as recomendações previstas dentro da legislação do órgão gestor, e ainda sugere um prazo de outorga a ser concedido. Como informações adicionais no processo de tomada de decisão, o programa pode gerar dois relatórios, onde o operador do programa é capaz de visualizar:

- Balanço hídrico de jusante;

- Lista completa de usuários.

Passo 5 - Inclusão do ponto de interferência: na versão interna, em Matlab, essa opção de incluir o ponto de interferência no SCBH é aberta. Após inclusão do ponto, as informações serão adicionadas ao banco de dados, a fim de que possam ser computadas no cálculo dos futuros pontos de interferência. Já na versão $W e b$, a opção de inclusão só é habilitada para operador com login e senha de órgão gestor; entrando como usuário de recursos hídricos, as informações servirão somente como consulta para verificação da disponibilidade hídrica no trecho e possibilidade (ou não) de outorga do ponto.

\section{2) "SCBH fiscalização"}

Passo 6 - Tipologia da interferência: adicional ao porte do trecho, essa é a segunda informação complementar a ser inserida no SCBH-fiscalização, para definição das recomendações de tipo de equipamentos a serem instalados. Três opções são possíveis:

- Tubulação sob pressão;

- Superfície livre; ou 
- Ambos (existem captações que utilizam bombeamento por gravidade para lançarem água num canal, que distribui por superfície livre).

Passo 7 - Definição dos índices absolutos e relativos: para o módulo de fiscalização do SCBH, deve-se definir os índices absolutos, que levam em conta comparativos de mínimo e máximo em termos de vazão demandada pelo ponto de interferência, e os índices relativos, que estabelece a disponibilidade hídrica no trecho, relacionando as vazões de demanda $\mathrm{Q}_{\text {demanda }}$ - com as vazões de referência para cada trecho i - $\mathrm{Q}_{\text {referencia }}$ (i).

No caso da bacia do São Francisco, os índices foram calculados como estudo de caso e préestabelecidos no item 5.4.3. Assim:

- $\underline{\text { Índices absolutos: }}$ QAB1 = 10 1/s (absoluto mínimo: $1^{\circ}$ estágio); QAB2 = 500 1/s (absoluto máximo: $3^{\circ}$ estágio).

- Índices relativos: PCC= 0,5 (50\%) - coletivo; P1CI1 = 0,005 (0,5\%) - individual, divide $1^{\circ}$ e $2^{\circ}$ estágios, trecho com menor comprometimento; P1CI2 = 0,05 (5\%) individual, divide $2^{\circ}$ e $3^{\circ}$ estágios, trecho com menor comprometimento; $\mathrm{P} 2 \mathrm{CI} 1=$ $0,003(0,3 \%)$ - individual, divide $1^{\circ}$ e $2^{\circ}$ estágios, trecho com maior comprometimento; P2CI2 = 0,03 (3\%) - individual, divide $2^{\circ}$ e $3^{\circ}$ estágios, trecho com maior comprometimento.

$\underline{\text { Passo } 8 \text { - Cálculo da vazão de demanda }\left(Q_{\text {demanda }} \text { ) e dos Indicadores de Comprometimento }\right.}$ Individual Máximo ( $\mathrm{ICI}_{\max }$ ) e Coletivo Máximo ( $\mathrm{ICC}_{\text {máx }}$ ): esse passo é nada mais que um processo interno do $\mathrm{SCBH}$, contando com os dados de entrada já inseridos. Considera-se a vazão de demanda $\left(\mathrm{Q}_{\text {demanda }}\right)$ como a máxima instantânea inserida pelo operador tanto na captação, quanto no lançamento (vide Passo 3). Em outras palavras, adota-se como regime de vazões o de máxima instantânea, pois é este regime que deve ser considerado para possibilidade de medir a vazão, critério diferente adotado na outorga.

Passo 9 - Classificação do ponto quanto ao monitoramento: calculada a vazão $Q_{\text {demanda }}$ e os indicadores $\mathrm{ICI}_{\max }$ e $\mathrm{ICC}_{\max }$, classifica-se o ponto de interferência num dos três estágios prédefinidos: monitoramento simplificado; monitoramento intermediário; ou monitoramento avançado, com a instalação de equipamento de medição. Para tanto, compara-se a vazão de demanda com os índices absolutos mínimos e máximos, já classificando o ponto de interferência diretamente no estágio 1 (mínimo) ou estágio 3 (máximo), se $\mathrm{Q}_{\text {demanda }}$ for menor que 
o mínimo ou maior que o máximo. Entretanto, estando o mesmo nos valores intermediários entre os valores de mínimo e máximo absolutos, classifica-se o ponto de interferência num dos três estágios pelos índices relativos, comparando-os com os Indicadores de Comprometimento Individual (ICI $\left.\mathrm{I}_{\text {máx }}\right)$ e Coletivo ( $\mathrm{ICC}_{\text {máx }}$ ).

Passo 11 - Resposta do "SCBH fiscalização": o sistema informa ao operador em que estágio de monitoramento está enquadrado: simplificado, intermediário ou avançado. No último caso, além da obrigação para instalação de equipamento, deve ser enviada a Declaração Anual de Uso de Recursos Hídricos. Sendo assim, como relatório de saída para cada um desses estágios, apresenta-se uma Planilha de Controle deve ser utilizada (Apêndice B) e quais equipamentos ou dispositivos recomenda-se a instalação (Apêndice D):

\section{Monitoramento Simplificado:}

- Envio da Planilha de Controle B.1;

- Disponibilização das tabelas e dispositivos acumuladores de tempo como opcional, se o usuário tiver interesse em instalação de algum equipamento de medição.

\section{Monitoramento Intermediário:}

- Envio da Planilha de Controle B.2;

- Disponibilização da tabela D.3 com dispositivos acumuladores de tempo;

- Disponibilização da tabela D.1 (se tubulação sob pressão), D2 (se superfície livre) como opcional, se o usuário tiver interesse em instalação de algum equipamento de medição;

- Realizar medição de vazão com equipamento, frequência mínima anual, e manter comprovante no empreendimento, e enviar ao órgão gestor, se requerido;

- Realizar análise laboratorial de $\mathrm{DBO}_{5,20}$, frequência mínima anual, manter comprovante no empreendimento e enviar ao órgão gestor, se requerido.

\section{Monitoramento Avançado:}

- Envio da Planilha de Controle B.3;

- Preenchimento e envio ao órgão gestor, por parte do usuário, da Planilha de Controle B.3, como Declaração Anual de Uso de Recursos Hídricos - DAURH. A mesma pode ser preenchida eletronicamente ou online, conforme o órgão gestor estabeleça; 
- Disponibilização da tabela D.1 (se tubulação sob pressão), D2 (se superfície livre), como opção para escolha do tipo de equipamento a ser instalado;

- Prazo para instalação de equipamento de medição após emissão da outorga - 180 (cento e oitenta) dias, por exemplo;

- Realizar análise laboratorial de $\mathrm{DBO}_{5,20}$, frequência mínima mensal, manter comprovante no empreendimento e enviar ao órgão gestor, se requerido. 


\section{CONCLUSÕES E RECOMENDAÇÕES}

O presente trabalho teve como ponto central a elaboração de um fluxograma como base para um sistema de suporte à decisão para controle de vazões outorgadas, tendo sido escolhido como estudo de caso os corpos hídricos de domínio da União da bacia do rio São Francisco. Para efetivação do controle das vazões outorgadas, utilizou-se o conceito de obrigação de monitoramento, por parte do usuário, do uso outorgado, definindo três estágios gradativos de exigência:

- $\quad$ Monitoramento simplificado, onde o usuário pode adotar os valores de projeto para ter conhecimento do uso outorgado, preenche os valores numa planilha;

- Monitoramento intermediário, em que se define um controle objetivo do tempo de utilização do ponto de interferência outorgado, mediante instalação de um dispositivo acumulador de tempo, e com adoção de medição de vazão máxima e de análise de $\mathrm{DBO}_{5,20}$ (se o ponto for de lançamento) com frequência mínima anual;

- $\quad$ Monitoramento avançado, com instalação de equipamento de medição de vazão que possa acumular o volume de água apropriado pelo ponto de interferência outorgado, além de envio de Declaração Anual de Uso de Recursos Hídricos, com os volumes mensais utilizados, e de análise de $\mathrm{DBO}_{5,20}$ (se o ponto for de lançamento) com frequência mínima mensal.

Pelo argumentado na parte teórica, verificou-se que o instrumento da outorga, sem o devido controle, pode apresentar uma considerável distância da realidade do uso numa determinada bacia ou trecho, o que diminui a eficiência de seu desempenho como um instrumento de regulação do uso da água.

Dessa forma, desenvolveu-se uma metodologia para classificação de usuários outorgados num dos três níveis de monitoramento estipulados (simplificado, intermediário e final), com índices que levam em conta critérios absolutos (vazão) e relativos (relação com vazão de referencia), tendo sido verificados em 27 trechos na bacia do rio São Francisco. Para teste e 
avaliação desses índices, foram criados indicadores gerais que levaram em conta a distribuição das vazões outorgadas e o número de usuários num dos três níveis de monitoramento. Foram criados 4 cenários com diferentes valores para os índices, tendo sido encontrados valores intermediários para os índices relativos absolutos e valores fixos para os índices absolutos.

Para a maioria das vazões outorgadas na bacia do São Francisco, os valores dos índices absolutos e relativos foram capazes, em linhas gerais, de apresentar uma classificação adequada no que tange aos três níveis de monitoramento, podendo adotar valores numéricos para construção de fluxograma do "módulo auxiliar" do SCBH para os trechos de domínio de União da bacia do São Francisco.

Entretanto, para alguns trechos em específico, tanto de menor porte (afluentes do rio São Francisco, tanto de maior porte (calha do rio São Francisco e principais reservatórios), verificou-se que a distribuição das vazões outorgadas num dos três níveis de exigência quanto ao monitoramento, não foi adequada, havendo um excesso de vazões classificadas nos níveis de exigência 2 (intermediário) e 3 (avançado) nos trechos de menor porte e, por outro lado, uma concentração das vazões outorgadas no nível 1 (simplificado) nos trechos de maior porte.

Tal fato se deve à dimensão da bacia do rio São Francisco: tendo sido dividida em 27 trechos, comporta uma grande diversidade em termos de disponibilidade de recursos hídricos, principalmente no que tange à variabilidade das vazões de referência, desde $Q_{\text {referência }}=8001 / \mathrm{s}$ (trecho $13=$ rio Verde Pequeno) a Qreferencia $=8000.000$ 1/s (trechos 21 a 27 - calha do rio São Francisco e reservatórios, a jusante da barragem de Sobradinho até a foz).

Como alternativa para este problema identificado, pode-se adotar uma metodologia diferente, definindo índices relativos mais restritivos para os trechos de menor porte (afluentes do rio São Francisco) e índices relativos menos restritivos para os trechos de maior porte (calha do rio e reservatórios).

Outra recomendação, para fins de teste e verificação da classificação das vazões outorgadas quanto ao tipo de monitoramento, seria avaliar a metodologia apresentada em bacias menores, como, por exemplo, a bacia do Descoberto (DF/GO). 


\section{REFERÊNCIAS BIBLIOGRÁFICAS}

Acre. Lei no 1500 - 15 jul. (2003). Institui a Política Estadual de Recursos Hídricos, cria o Sistema Estadual de Gerenciamento de Recursos Hídricos do Estado do Acre, dispõe sobre infrações e penalidades aplicáveis e dá outras providências. Diário Oficial do Estado do Acre, 16 jul. 2003.

Alagoas. Decreto $\mathrm{n}^{\circ} 6$ - 23 jan. (2001). Regulamenta a outorga de direito de uso de recursos hídricos prevista na lei n. $^{\circ} 5.965$, de 10 de novembro de 1997 , que dispõe sobre a Política Estadual de Recursos Hídricos, institui o Sistema Estadual de Gerenciamento Integrado de Recursos Hídricos e dá outras providências. Diário Oficial do Estado de Alagoas, 24 jan. 2001.

Almeida, J. C. (2009). A indústria sucroalcooleira-energética e os recursos hídricos: rio Santo Antônio Grande, Alagoas. Dissertação de Mestrado, Universidade Federal de Alagoas, Maceió, AL, 90p.

Alter, S.L. (1980). "Decision Support System: current practices and continuing challenges". Addison Wesley Publishing Company.

Agência Nacional de Águas (2006). Topologia hídrica: método de construção e modelagem da base hidrográfica para suporte à gestão de recursos hídricos: versão 1.11. Superintendência de Gestão da Informação, Brasília, Brasil, 29 p.

Agência Nacional de Águas - ANA (2016). Vazão mínima defluente de Sobradinho e Xingó permanece em $800 \mathrm{~m}^{3} / \mathrm{s}$ até 31 de março. Disponível em: <http://www2.ana.gov.br/Paginas/imprensa/noticia.aspx?id_noticia=12924> acesso em 11 de fevereiro de 2016.

Amapá. Lei no 686 - 7 jun. (2002). Dispõe sobre a política de gerenciamento dos recursos hídricos do Estado do Amapá e dá outras providências. Diário Oficial do Estado do Amapá, 7 jun. 2002.

Amazonas. Decreto n ${ }^{\circ} 28.678$ - 16 jun. (2009). Regulamenta a Lei n. ${ }^{03.167}$, de 27 de agosto de 2007, que reformula as normas disciplinadoras da Política Estadual de Recursos Hídricos e do Sistema Estadual de Gerenciamento de Recursos Hídricos, e dá outras providências. Diário Oficial do Estado do Amazonas, 16 jun. 2009.

Azevedo Netto, J. M. et al. (2002). Manual de Hidráulica. Edgard Blücher Ltda., São Paulo, Brasil, 680p.

Bahia. Instituto de Gestão das Águas e Clima - Ingá. Instrução Normativa n 08-A - 30 dez. (2010). Dispõe sobre critérios técnicos para a medição do volume de água captado em corpos de água de domínio do Estado da Bahia e dá outras providências. Diário Oficial do Estado da Bahia, 6 jan. 2010.

Bahia. Decreto n ${ }^{\circ} 6.296$ - 21 mar (1997). Dispõe sobre a outorga de direito de uso de recursos hídricos, infração e penalidades e dá outras providências. Diário Oficial do Estado da Bahia, 21 mar. 1997.

Barcellos, F. C.; Acselrad, M. V.; Costa, V. G. (2011). "Efetividade na aplicação de recursos obtidos com a cobrança pelo uso da água bruta na porção fluminense da Bacia do Paraíba do Sul". Revibec: Revista Iberoamericana de Economía Ecológica, 16 (1), 1-15.

Benetti, A. D.; Lanna, E.; Cobalchini, M. S. (2003). "Metodologias para determinação de vazões ecológicas em rios" Revista Brasileira de Recursos Hídricos, 8(2), 149-160. 
Brasil. Constituição (1988). Constituição da República Federativa do Brasil: promulgada em 5 de outubro de 1988. Diário Oficial da União, Brasília, 5 out. Atualização disponível em: www.planalto.gov.br/ccivil_03/Constituicao/Constituicao.htm.

Brasil. Lei no 9.433 - 8 jan. (1997). Institui a Política Nacional de Recursos Hídricos, cria o Sistema Nacional de Gerenciamento de Recursos Hídricos, regulamenta o inciso XIX do art. 21 da Constituição Federal, e altera o art. $1^{\circ}$ da Lei $n^{\circ} 8.001$, de 13 de março de 1990, que modificou a Lei ${ }^{\circ} 7.990$, de 28 de dezembro de 1989. Diário Oficial da União, Brasília, Seção 1, 9 jan, 470-474.

Brasil. Lei ñ 9.984 - 17 jul. (2000a). Dispõe sobre a criação da Agência Nacional de Águas - ANA, entidade federal de implementação da Política Nacional de Recursos Hídricos e de coordenação do Sistema Nacional de Gerenciamento de Recursos Hídricos. Diário Oficial da União, Brasília, Seção 1, 18 jul, 1-4.

Brasil. Ministério do Meio Ambiente. Instrução Normativa no 4 - 21 jun. (2000b). Aprova os procedimentos administrativos para a emissão de outorga de direito de uso de recursos hídricos, em corpos d"água de domínio da União. Diário Oficial da União, Brasília, Seção 1, 3 jul, 25-30.

Brasil. Conselho Nacional de Recursos Hídricos - CNRH. Resolução no 16 - 8 mai. (2001). Estabelece critérios gerais para a outorga de direito de uso de recursos hídricos. Diário Oficial da União, Brasília, Seção 1, 14 mai, 269-270.

Brasil. Agência Nacional de Águas - ANA. Resolução no 123 - 1 jul. (2002). Direito de Outorga - Carlos Lucas Mendes. Diário Oficial da União, Brasília, Seção 1, 5 jul, 162.

Brasil. Agência Nacional de Águas - ANA. Resolução no 425 - 4 ago. (2004a). Estabelece critérios para medição de volume de água captada em corpos de água de domínio da União. Diário Oficial da União, Brasília, Seção 1, 30 ago, 116.

Brasil. Agência Nacional de Águas - ANA. Resolução no 707 - 4 ago. (2004b). Dispõe sobre procedimentos de natureza técnica e administrativa a serem observados no exame de pedidos de outorga, e dá outras providências. Boletim de Pessoal e Serviço $n^{\circ} 12$, Brasília, 3 jan. 2005.

Brasil. Conselho Nacional de Meio Ambiente - CONAMA. Resolução no 357 - 17 mar. (2005). Dispõe sobre a classificação dos corpos de água e diretrizes ambientais para o seu enquadramento, bem como estabelece as condições e padrões de lançamento de efluentes, e dá outras providências. Diário Oficial da União, Brasília, Seção 1, 18 mar, 58-63.

Brasil. Agência Nacional de Águas - ANA. Resolução no 340 - 10 ago. (2006a). Direito de Outorga - Usuários de recursos hídricos na bacia do Ribeirão Pipiripau. Diário Oficial da União, Brasília, Seção 1, 18 ago, 51-52.

Brasil. Agência Nacional de Águas - ANA. Resolução no 127 - 3 abr. (2006b). Estabelece o marco regulatório de procedimentos e critérios de outorga de direito de uso de recursos hídricos na Bacia do Ribeirão Pipiripau, considerando a regularização das intervenções e usos atuais. Diário Oficial da União, Brasília, Seção 1, 25 abr, 70-71.

Brasil. Agência Nacional de Águas - ANA. Resolução no 782 - 27 out. (2009). Estabelece critérios para o envio dos dados dos volumes medidos em pontos de interferência outorgados em corpos de água de domínio da União. Diário Oficial da União, Brasília, Seção 1, 5 nov, 84. 
Brasil. Conselho Nacional de Recursos Hídricos - CNRH. Resolução n ${ }^{\circ} 113$ - 10 jun. (2010a). Aprova os parâmetros para usos de pouca expressão para isenção da obrigatoriedade da outorga de uso de recursos hídricos na Bacia Hidrográfica do Rio São Francisco. Diário Oficial da União, Brasília, Seção 1, 28 jun, 116.

Brasil. Agência Nacional de Águas - ANA. Resolução no 77 - 22 mar. (2010b). Delega competência para emissão de outorga preventiva e de direito de uso de recursos hídricos de domínio da União no âmbito do Distrito Federal, e dá outras providências na implementação da Agenda Operativa. Diário Oficial da União, Brasília, Seção 1, 23 mar, 51.

Brasil. Agência Nacional de Águas - ANA. Resolução no 389 - 22 ago. (2012). Direito de Outorga - Companhia Hidro Elétrica do São Francisco - CHESF, Reservatório da UHE de Apolônio Salles/Moxotó (rio São Francisco), Município de Glória/Bahia, irrigação. Diário Oficial da União, Brasília, Seção 1, 24 ago, 94.

Brasil. Agência Nacional de Águas - ANA. Resolução no 1041 - 19 ago. (2013). Define os critérios para análise de balanço hídrico em pedidos de outorga preventiva e de direito de uso de recursos hídricos para captação de água e lançamento de efluentes com fins de diluição, bem como para prazos de validade das outorgas de direito de uso de recurso hídricos e dá outras providências. Diário Oficial da União, Brasília, Seção 1, 27 ago, 107.

Brasil. Agência Nacional de Águas - ANA. Resolução no 1492 - 18 dez. (2015). Dispõe sobre a redução temporária da descarga mínima defluente dos reservatórios de Sobradinho e Xingó, no rio São Francisco. Diário Oficial da União, Brasília, Seção 1, 22 dez, 175.

Brigagão, E. N. (2006). Integração de análise econômica e financeira a sistemas de apoio a decisão de enquadramento, outorga e cobrança de recursos hídricos: aplicação à bacia da barragem do Descoberto no Distrito Federal. Dissertação de Mestrado, Departamento de Engenharia Civil e Ambiental, Universidade de Brasília, Brasília, DF, 133p.

Bof, L. H. N.; Pruski, F. F. \& Souza, W. A. M. (2009). "Impacto do uso de diversos critérios para a concessão de outorga". XVIII Simpósio Brasileiro de Recursos Hídricos, 22 a 26 de novembro de 2009, Campo Grande, MS, Brasil.

Carolo, F. (2007). Outorga de direito de uso de recursos hídricos: Instrumento para o desenvolvimento sustentável? Estudos das bacias dos rios Piracicaba, Capivari e Jundiaí. Dissertação de mestrado, Universidade de Brasília, Centro de Desenvolvimento Sustentável, Brasília, DF, 203 p.

Ceará. Decreto no 30.629 - 19 ago. (2011). Dispõe sobre a cobrança pelo uso dos recursos hídricos superficiais e subterrâneos de domínio do estado do Ceará ou da União por delegação de competência, e dá outras providências. Diário Oficial do Estado do Ceará, 23 ago. 2011.

Ceará. Secretaria dos Recursos Hídricos - SRH. Instrução Normativa SRH n ${ }^{\circ} 01$ - 2 jun. (2004). Estabelece os procedimentos gerais de leitura, faturamento, operacionalização técnica de medição, recursos e direito dos usuários de água. Diário Oficial do Estado do Ceará, 14 jul. 2004.

Chaves, H. M. L. \& Piau, L. P. A. (2008) "Efeito da variabilidade da precipitação pluvial e do uso e manejo do solo sobre o escoamento superficial e o aporte de sedimento de uma bacia hidrográfica do Distrito Federal". Revista Brasileira de Ciência do Solo, 32(1), 333-343. 
Collischonn, B. (2014). "Sistema de apoio à decisão para outorga de direito de uso de recursos hídricos". Tese de Doutorado, Universidade Federal do Rio Grande do Sul, Porto Alegre, RS, 177p.

Collischonn, B. \& Lopes, A.V. (2009). "Sistema de apoio à decisão para análise de outorga na bacia do rio Paraná". XVIII Simpósio Brasileiro de Recursos Hídricos, 22 a 26 de novembro de 2009, Campo Grande, MS, Brasil.

Couceiro, S. R. M.; Hamada, N. (2011). "Os instrumentos da Política Nacional de Recursos Hídricos na região norte do Brasil”. Oecologia Australis, 15(4), 762-774.

Cruz, J. C. (2001). Disponibilidade hídrica para outorga: avaliação de aspectos técnicos e conceituais. Tese de Doutorado, Universidade Federal do Rio Grande do Sul, Porto Alegre, RS, 189p.

Cruz, M. A. S. (2004). Otimização do controle da drenagem em macrobacias urbanas. Tese de Doutorado, Universidade Federal do Rio Grande do Sul, Porto Alegre, RS, 190p.

Dalfior, J. S.; Sado, R. R. (2013). "Resultado das ações de fiscalização em rios federais na bacia do rio Doce". XX Simpósio Brasileiro de Recursos Hídricos, 17 a 22 de novembro de 2013, Bento Gonçalves, RS, Brasil.

Distrito Federal. Decreto ${ }^{\circ} 22.359$ - 31 ago. (2001). Dispõe sobre a outorga de direito de uso de recursos hídricos no território do Distrito Federal e dá outras providências. $\mathrm{Di}$ ário Oficial do Distrito Federal, 3 set. 2001.

Distrito Federal. Agência Reguladora de Águas e Saneamento do Distrito Federal - Adasa. Resolução no 350 - 23 jun. (2006). Estabelece os procedimentos gerais para requerimento e obtenção de outorga do direito de uso dos recursos hídricos em corpos de água de domínio do Distrito Federal e em corpos de água delegados pela União e Estados. Diário Oficial do Distrito Federal, 10 jul. 2006.

Distrito Federal. Agência Reguladora de Águas e Saneamento do Distrito Federal - Adasa. Nota Técnica $\mathrm{n}^{\circ} 27$ - 5 nov. (2012a). Estabelece os procedimentos e critérios a serem utilizados para determinar os valores de vazão a serem outorgados aos usuários localizados na bacia do ribeirão Pipiripau.

Distrito Federal. Agência Reguladora de Águas e Saneamento do Distrito Federal - Adasa. Resolução nº 6 - 23 nov. (2012b). Outorga à Associação dos Usuários do Canal Santos Dumont o direito de uso de água superficial captada no ribeirão Pipiripau, para atender a(s) finalidade(s) de abastecimento humano, criação de animais e irrigação. Diário Oficial do Distrito Federal, 26 nov., 64.

Distrito Federal. Agência Reguladora de Águas e Saneamento do Distrito Federal - Adasa. Resolução no 9 - 23 nov. (2012c). Outorga à Companhia de Saneamento Ambiental do Distrito Federal o direito de uso de água superficial captada no ribeirão Pipiripau, para atender a finalidade de abastecimento humano. Diário Oficial do Distrito Federal, 26 nov., 64 .

Espírito Santo. Instituto Estadual de Meio Ambiente e Recursos Hídricos - Iema. Instrução Normativa $n^{\circ} 019$ - 4 Out. (2005). Estabelece procedimentos administrativos e critérios técnicos referentes à outorga de direito de uso de recursos hídricos em corpos de água do domínio do Estado do Espírito Santo. Diário Oficial do Estado do Espírito Santo, 6 out. 2005. 
Ferraz, A. R. G.; Braga, B. (1998). "Modelo Decisório para a outorga de direito de uso da água no Estado de São Paulo”. Revista Brasileira de Recursos Hídricos, 3(2), 5-19.

Frangipani, M. (2007). Guias práticos: técnicas de operação em sistemas de abastecimento de água - Volume 1: Macromedição. Secretaria Nacional de Saneamento Ambiental, Brasília, Brasil, 79p.

Garcia, J. I. B. (2011). Sistema de suporte a decisão para o lançamento de efluentes. Tese de Doutorado, Escola Politécnica da Universidade de São Paulo, São Paulo, SP, 162p.

Giboshi, M. L.; Rodrigues, L. H. A.; Lombardi Neto, F. (2006). "Sistema de suporte à decisão para recomendação de uso e manejo da terra". Revista Brasileira de Engenharia Agrícola e Ambiental, 10(4), 861-866.

Goiás. Conselho Estadual de Recursos Hídricos - CERHI-GO. Resolução n ${ }^{\circ} 09$ - 4 mai. (2005). Estabelece o Regulamento do Sistema de outorga das águas de domínio do Estado de Goiás e dá outras providências. Diário Oficial do Estado de Goiás, 2 jun. 2005.

Goiás. Secretaria de Estado de Meio-Ambiente e dos Recursos Hídricos. Instrução Normativa $n^{\circ} 015$ - 1 out. (2012). Dispõe sobre os procedimentos de outorga para usos de recursos hídricos no Estado de Goiás e dá outras providências. Diário Oficial do Estado de Goiás, 1 out, p. 8.

Guimarães, A. B. (2007). Medidor de vazão proporcional para a quantificação do consumo de água na irrigação. Dissertação de Mestrado, Universidade Federal de Santa Maria, Santa Maria, RS, 113p.

Harris, N. M.; Gurnell, A. M.; Hannah, D. M.; Petts, G. E. (2000). "Classification of river regimes: a context for hydroecology”. Hydrological Processes, 14(1), 2831-2848.

Kelman, J. (1997). "Gerenciamento de recursos hídricos: parte I - outorga". Anais do XII Simpósio Brasileiro de Recursos Hídricos, Vol. 1, 123-128, Vitória, ES, Brasil.

Lamon, G. P. S. (2006). Pitometria e macromedição nas empresas de saneamento. Unigraf, Belo Horizonte, Brasil, 180p.

Lanna, A. E. L. (2002). “Cap. 1: Introdução”. In: Porto, R.L.L. (org.) Técnicas quantitativas para o gerenciamento de recursos hídricos. Associação Brasileira de Recursos Hídricos - ABRH, Editora da UFRGS, Porto Alegre, Brasil, 15-41.

Lynnworth, L.C.; Liu, Y. (2006). "Ultrasonic flowmeters: Half-century progress report, 1955-2005”. Ultrasonics, 44 (1), 1371-1378.

Loucks, D.P. (1995). "Developing and implementing decision support systems: A critique and a challenge". Water Resources Bulletin, 31(4), 571-582.

Maranhão. Lei no 8.149 - 15 jun. (2004). Dispõe sobre a Política Estadual de Recursos Hídricos, o Sistema de Gerenciamento Integrado de Recursos Hídricos, e dá outras providências. Diário Oficial do Estado do Maranhão, 23 jun. 2004.

Marques, F. A. (2006). Sistema multiusuário de gestão de recursos hídricos. Dissertação de Mestrado, Universidade Federal de Viçosa, Viçosa, MG, 112p.

Mato Grosso. Decreto no 336 - 6 jun. (2007). Regulamenta a outorga de direitos de uso dos recursos hídricos e adota outras providências. Diário Oficial do Estado do Mato Grosso, 6 jun. 2007. 
Mato Grosso do Sul. Lei no 2.406 - 29 Jan. (2002). Institui a Política Estadual dos Recursos Hídricos, cria o Sistema Estadual de Gerenciamento dos Recursos Hídricos e dá outras providências. Diário Oficial do Estado do Mato Grosso do Sul, 30 jan. 2012.

Matos, J. C. (2004). Suporte metodológico para avaliação de pleitos de outorga dos recursos hídricos - aplicação para o caso da bacia hidrográfica do rio Jacuípe no estado da Bahia. Dissertação de Mestrado, Departamento de Engenharia Civil e Ambiental, Universidade de Brasília, Brasília, DF, 153p.

Meneses Filho, A. S.; Tucci, C. E. M. (2003). "Impacto da urbanização na produção anual de cargas poluentes, com incerteza". Anais do $6^{\circ}$ Simpósio de hidráulica e recursos hídricos dos países de língua oficial portuguesa, Vol. I, 889-901, Cabo Verde.

Michalski, A. (2001). "A new approach to estimating the main error of a primary transducer for an electromagnetic flowmeter". IEEE transactions on instrumentation and measurement, 50(3), 764-767.

Minas Gerais. Instituto Mineiro de Gestão das Águas - IGAM. Portaria Administrativa n ${ }^{\circ} 10$ - 30 dez. (1998). Regulamenta o processo de outorga de direito de uso de águas de domínio do Estado de Minas Gerais. Diário Oficial do Estado de Minas Gerais, 23 jan. 1999.

Minas Gerais. Instituto Mineiro de Gestão das Águas - IGAM. Portaria Administrativa no 49 - 1 jul. (2010). Estabelece os procedimentos para a regularização do uso de recursos hídricos do domínio do Estado de Minas Gerais. Diário Oficial do Estado de Minas Gerais, 6 jul. 2010.

Neves, M. M. (2005). Potencial da metodologia TMDL como mecanismo de enquadramento de corpos de água. Dissertação de mestrado, Escola Politécnica da Universidade de São Paulo, São Paulo, SP, 256 p.

Pará. Conselho Estadual dos Recursos Hídricos - Cerh. Resolução no. 003 - 3 set. (2008). Dispõe sobre a outorga de direito de uso de recursos hídricos e dá outras providências. Diário Oficial do Estado do Pará, 3 set. 2008.

Pereira, P. R. G. (2000). Suporte Metodológico de Apoio a decisões no Processo de Outorga dos Direitos de Uso de Recursos Hídricos, aplicação para o caso da bacia do Lago Descoberto (Distrito Federal / Goiás). Dissertação de Mestrado, Departamento de Engenharia Civil e Ambiental, Universidade de Brasília, Brasília, 128p.

Pernambuco. Lei Estadual no 12.984 - 30 dez. (2005). Dispõe sobre a Política Estadual de Recursos Hídricos e o Sistema Integrado de Gerenciamento de Recursos Hídricos, e dá outras providências. Diário Oficial do Estado do Pernambuco, 31 dez. 2005.

Paraíba. Decreto no 19.260 - 31 out. (1997). Regulamenta a outorga do direito de uso dos recursos hídricos e dá outras providências. Diário Oficial do Estado da Paraíba, 1 nov. 1997.

Paraná. Decreto no 4646 - 31 ago. (2001). Dispõe sobre o regime de outorga de direitos de uso de recursos hídricos e adota outras providências. Diário Oficial do Estado do Paraná, 31 ago. 2001.

Pereira, C. C. G.; Thomas, P. T.; Alves, R. F. F. (2011). "Processo de regularização de usos e operacionalização da cobrança pelo uso de recursos hídricos na bacia hidrográfica Rio São Francisco" XIX Simpósio Brasileiro de Recursos Hídricos, 27 de novembro a 1 de dezembro de 2011, Maceió, Al, Brasil. 
Piauí. Decreto no 11.341 - 22 mar. (2004). Regulamenta a outorga preventiva de uso e a outorga de direito de uso de recursos hídricos do Estado do Piauí, nos termos da Lei nº 5.165, de 17 de agosto de 2000. Diário Oficial do Estado do Piauí, 25 mar. 2005.

Pinto, L. C. B. (2003). Procedimento alternativo para totalização volumétrica indireta de água bruta. Tese de Doutorado, Universidade Estadual de Campinas, Faculdade de Engenharia Civil, Campinas, SP, 104p.

Porto, R. M. (2006). Hidráulica Básica. Escola de Engenharia de São Carlos, Universidade de São Paulo, São Paulo, Brasil, 540p.

Porto, R. L.; Azevedo, L. G. T; Zahed Fo, K. (2002). “Cap.4: Modelos de simulação e de rede de fluxo". In: Porto, R. L. L. (org.). Técnicas quantitativas para o gerenciamento de recursos hídricos. Associação Brasileira de Recursos Hídricos - ABRH, Editora da UFRGS, Porto Alegre, Brasil, 165-238.

Porto, R. L.; Azevedo, L. G. T. (2002). "Cap.2: Sistemas de suporte a decisões aplicados a problemas de recursos hídricos". In: Porto, R. L. L. (org.). Técnicas quantitativas para o gerenciamento de recursos hídricos. Associação Brasileira de Recursos Hídricos ABRH, Editora da UFRGS, Porto Alegre, Brasil, 42-95.

Porto, R. L.; Roberto, A. N.; Mello Junior, A. V.; Palos, J. C. F. (2005). “AcquaNet: arquitetura, estratégias e ferramentas". XVI Simpósio Brasileiro de Recursos Hídricos, 20 a 24 de novembro de 2005, João Pessoa, PB, Brasil.

Pozzebon, E.; Cunha, P.; Cavalcante, A. C.; Carrari, E.; Silva, L. M. C. (2003). "Demanda hídrica para agricultura irrigada e sua influência nas análises de pedidos de outorga de direito de uso da água". XV Simpósio Brasileiro de Recursos Hídricos, 23 a 27 de novembro de 2003, Curitiba, PR, Brasil.

Ramos, V. S. (2006). Uso das técnicas de radiotraçadores e de contagem total em medidas de vazão de sistemas abertos. Dissertação de mestrado, Universidade Federal do Rio de Janeiro, Instituto Alberto Luiz Coimbra de Pós-Graduação e Pesquisa de Engenharia - COPPE, Rio de Janeiro, RJ, 79 p.

Ravanello, M. (2007). Análise técnica, legal e social para subsídios à outorga de direito de uso de recursos hídricos na bacia hidrográfica do rio Ibicuí-RS. Dissertação de mestrado, Universidade Federal de Santa Maria, Santa Maria, RS, 123p.

Rio de Janeiro. Instituto Estadual do Ambiente - Inea. Portaria Serla n ${ }^{\circ} 567$ - 7 mai. (2007). Estabelece critérios gerais e procedimentos técnicos e administrativos para cadastro, requerimento e emissão de outorga de direito de uso de recursos hídricos de domínio do Estado do Rio de Janeiro, e dá outras providências. Diário Oficial do Estado do Rio de Janeiro, 7 mai. 2007.

Rio Grande do Norte. Decreto n ${ }^{\circ} 13.283$ - 22 mar. (1997). Regulamenta os incisos III do art. $4^{\text {o }}$ da Lei ${ }^{\circ}$ 6.908, de 01 de julho de 1996, que dispõe sobre a Política Estadual de Recursos Hídricos, e dá outras providências. Diário Oficial do Estado do Rio Grande do Norte, 22 mar. 1997.

Rio Grande do Sul. Decreto no 37.033 - 21 nov. (1996). Regulamenta a outorga do direito de uso da água no estado do Rio Grande do Sul, prevista nos artigos 29, 30 E 31 DA Lei n. ${ }^{\circ} 10.350$, de 30 de dezembro de 1994. Diário Oficial do Estado do Rio Grande do Sul, 22 nov. 1996. 
Roberto, A. N. (2002) Modelos de rede de fluxo para alocação da água entre múltiplos usos em uma bacia hidrográfica. Dissertação de Mestrado, Escola Politécnica da Universidade de São Paulo, São Paulo, SP, 105p.

Rodrigues, R. B. (2000). Metodologia de apoio à concessão de outorga para lançamento de efluentes e cobrança pelo uso da água - O modelo RM1. Dissertação de Mestrado, Escola Politécnica da Universidade de São Paulo, São Paulo, SP, 140p.

Rodrigues, R. B. (2005). SSD RB - Sistema de suporte a decisão proposto para a gestão quali-quantitativa dos processos de outorga e cobrança pelo uso da água. Tese de Doutorado, Escola Politécnica da Universidade de São Paulo, São Paulo, SP, 155p.

Rondônia. Decreto no 10.114 - 20 set. (2002). Regulamenta a Lei Complementar no 255, de 25 de janeiro de 2002, que institui a política, cria o sistema de gerenciamento e o fundo de recursos hídricos do Estado de Rondônia, e dá outras providências. Diário Oficial do Estado de Rondônia, 20 set. 2002.

Roraima. Decreto n ${ }^{\circ}$ 8.123-E - 12 jul. (2007). Regulamenta a outorga de direito de uso de recursos hídricos no território do Estado de Roraima. Diário Oficial do Estado de Rondônia, 12 jul. 2007.

Rosa de Oliveira, J.; Pruski, F.; Araújo Nunes, A. (2013). "Otimização do aproveitamento da disponibilidade de águas superficiais do ribeirão Entre Ribeiros. Revista Brasileira de Recursos Hídricos, 18 (4), 157-172.

Salim, F. P. C.; Roques, T. V. P.; Souza, W. G. (2007). "Definição de critérios técnicos de análise de outorga para diluição de efluentes em cursos de água: o caso do Estado do Espírito Santo". Anais do XVII Simpósio Brasileiro de Recursos Hídricos Vol. 1, 523534, São Paulo, SP, Brasil.

Santa Catarina. Decreto $\mathrm{n}^{\circ} 4.778$ - 11 out. (2006). Regulamenta a outorga de direito de uso de recursos hídricos, de domínio do Estado, de que trata a Lei Estadual n ${ }^{\circ}$ 9.748, de 30 de novembro de 1994, e estabelece outras providências. Diário Oficial do Estado de Santa Catarina, 11 out. 2006.

Santana, A. G; Cardoso, E.; da Silva, F. F.; Pereira, J. S. (2002). "Metodologia para controle das outorgas de uso da água em bacias hidrográficas". VI Simpósio de Recursos Hídricos do Nordeste, 3 a 6 de dezembro de 2002, Maceió, AL, Brasil.

Santos, I. et al. (2003). Hidrometria aplicada. Instituto de Tecnologia para o Desenvolvimento, Curitiba, Brasil, 372p.

São Paulo. Decreto no 41.258 - 31 out. (1996). Aprova o regulamento da outorga de direitos de uso dos recursos hídricos, de que tratam os artigos $9^{\circ}$ a 13 da Lei $\mathrm{n}^{\circ} 7.663$, de 30 de dezembro de 1991. Diário Oficial do Estado de São Paulo, 1 nov. 1996.

Sergipe. Decreto ${ }^{\circ} 18.456$ - 3 dez. (1999). Regulamenta a outorga de direito de uso de recursos hídricos, de domínio do Estado, de que trata a Lei n ${ }^{\circ} 3.870$, de 25 de setembro de 1997, e dá providências correlatas. Diário Oficial de Sergipe, 3 dez. 1999.

Silva, L. M. C.; Monteiro, R. A. (2004). "Outorga de direito de uso de recursos hídricos: uma das possíveis abordagens”. In: Machado, C. J. S. (org.). Gestão de Águas Doces. Interciência, Rio de Janeiro, Brasil, 135-178.

Silva, A. M.; Oliveira, P. M., Mello, C. R., Pierangeli, C. (2006). "Vazões mínimas e de referência para outorga na região do Alto Rio Grande, Minas Gerais". Revista Brasileira de Engenharia Agrícola e Ambiental, 10(2), 374-380. 
Silva Neto, A. R. (2011). Cenários de abastecimento futuro de Palmas-TO com base na simulação da disponibilidade hídrica do Ribeirão Taquarussu Grande. Dissertação de mestrado, Universidade Federal do Rio Grande do Sul, Porto Alegre, RS, 78 p.

Silveira, G. L.; Robaina, A. D.; Giotto, E.; Dewes, R. (1998). “Outorga para uso dos recursos hídricos: aspectos práticos e conceituais para o estabelecimento de um sistema informatizado". Revista Brasileira de Recursos Hídricos, 3 (3), 5-16.

Souza, J. D.; Sluter, C. R.; Braga, M. C. B. (2009). "Modelo espaço-temporal em SIG para análise de qualidade da água em uma bacia hidrográfica". Boletim de Ciências Geodésicas, 15(2), 224-244.

Spagnolo, T. F. O.; Gomes, R. A. T.; Junior, O. A. C.; Guimarães, R. F.; de Sousa Martins, É.; \& Junior, A. F. C. (2012). Dinâmica da expansão agrícola do município de São Desidério-BA entre os anos de 1984 a 2008, importante produtor nacional de soja, algodão e milho. Geo UERJ, 2(23), 603-618.

Streeter, V. L. (1977). Mecânica dos Fluidos. McGraw-Hill do Brasil, São Paulo, Brasil, $585 \mathrm{p}$.

Tocantins. Decreto $\mathrm{n}^{\mathrm{o}} 2.432-6$ jun. (2005). Regulamenta a outorga do direito de uso de recursos hídricos de que dispõem os artigos $8^{\circ}, 9^{\circ}$ e 10 da Lei 1.307 , de 22 de março de 2002. Diário Oficial do Estado de Tocantins, 7 jun. 2005.

Vera, L. H. A. (2014). Atuação da cobrança pelo uso da água de domínio da união como instrumento de gestão de recursos hídricos na Bacia Hidrográfica do Rio São Francisco. Dissertação de mestrado, Universidade Federal de Pernambuco, Recife, PE, $165 \mathrm{p}$.

Waldman, M. (2003). "Mais água, menos lixo: reciclar ou repensar?”, Boletim Paulista de Geografia (BPG), 79, 91-106. 


\section{APÊNDICES}

\section{APÊNDICE A - EXIGÊNCIAS LEGAIS DOS ÓRGÃOS GESTORES ESTADU- AIS QUANTO AO MONITORAMENTO DA VAZÃO OUTORGADA}

\begin{tabular}{|c|c|c|c|}
\hline Estado & $\begin{array}{l}\text { Órgão Gestor de } \\
\text { Recursos Hídricos }\end{array}$ & $\begin{array}{c}\text { Referência } \\
\text { Legal }\end{array}$ & $\begin{array}{c}\text { Exigências quanto ao } \\
\text { monitoramento da vazão outorgada }\end{array}$ \\
\hline $\mathrm{AC}$ & $\begin{array}{l}\text { Imac - Instituto de } \\
\text { Meio Ambiente do } \\
\text { Acre }\end{array}$ & $\begin{array}{l}\text { Lei } n^{\circ} 1.500 \\
(\text { Acre, } 2003)\end{array}$ & $\begin{array}{l}\text { Não foi identificado decreto que regulamenta a Lei, nem ins- } \\
\text { trução normativa ou resolução do órgão gestor. }\end{array}$ \\
\hline $\mathrm{AL}$ & $\begin{array}{l}\text { Semarh - Secretaria } \\
\text { de Estado do Meio } \\
\text { Ambiente e dos Re- } \\
\text { cursos Hídricos }\end{array}$ & $\begin{array}{l}\text { Decreto } n^{\circ} 6 \\
\text { (Alagoas, } \\
2001)\end{array}$ & $\begin{array}{l}\text { Art. } 23 \text { - Deverá constar no ato de outorga:... } \\
\text { VII - condição de que o outorgado deverá implantar e manter } \\
\text { em funcionamento equipamentos de medição para monitora- } \\
\text { mento contínuo da vazão captada e lançada. }\end{array}$ \\
\hline AM & $\begin{array}{l}\text { Ipaam - Instituto de } \\
\text { Proteção Ambiental } \\
\text { do Amazonas }\end{array}$ & $\begin{array}{c}\text { Decreto } \\
\text { n. }{ }^{\circ} 28.678 \\
(\text { Amazonas, } \\
\text { 2009) }\end{array}$ & $\begin{array}{l}\text { Art. } 54 \text { - Deverá o outorgado: ... } \\
\text { VI. Instalar e operar estações e equipamentos hidrométricos, } \\
\text { encaminhando ao IPAAM os dados observados e medidos, na } \\
\text { forma preconizada no ato de outorga e nas normas de proce- } \\
\text { dimentos estabelecidas, mediante Instrução Normativa* da } \\
\text { Secretaria de Estado do Meio Ambiente e Desenvolvimento } \\
\text { Sustentável (SDS). } \\
\text { * OBS: Não foi identificada publicação de Instrução Norma- } \\
\text { tiva por parte da SDS }\end{array}$ \\
\hline AP & $\begin{array}{l}\text { Imap - Instituto do } \\
\text { Meio Ambiente e de } \\
\text { Ordenamento Terri- } \\
\text { torial do Estado do } \\
\text { Amapá }\end{array}$ & $\begin{array}{l}\text { Lei no } 686 \\
\text { (Amapá, } \\
\text { 2002) }\end{array}$ & $\begin{array}{l}\text { Não foi identificado decreto que regulamenta a Lei, nem ins- } \\
\text { trução normativa ou resolução do órgão gestor. }\end{array}$ \\
\hline BA & $\begin{array}{l}\text { Inema - Instituto do } \\
\text { Meio Ambiente e } \\
\text { Recursos Hídricos }\end{array}$ & $\begin{array}{l}\text { Decreto } \\
\mathrm{n}^{\circ} 6.296 \\
\text { (Bahia, } \\
\text { 1997). }\end{array}$ & $\begin{array}{l}\text { Art. } 9^{\circ} \text { - Quando considerado conveniente, os outorgados de- } \\
\text { verão instalar e operar estações e equipamentos hidrométri- } \\
\text { cos, ou arcar com os respectivos custos, ficando obrigados a } \\
\text { encaminhar os dados observados e medidos à SRH*, na } \\
\text { forma preconizada no ato de outorga e de conformidade com } \\
\text { as normas e procedimentos estabelecidos. } \\
\text { *OBS: SRH - Secretaria de Recursos Hídricos (atual Inema) }\end{array}$ \\
\hline $\mathrm{CE}$ & $\begin{array}{l}\text { Cogerh - Compa- } \\
\text { nhia de Gestão dos } \\
\text { Recursos Hídricos }\end{array}$ & $\begin{array}{c}\text { Instrução } \\
\text { Normativa } \\
\text { SRH n }{ }^{\circ} 01 \\
(\text { Ceará, 2004) }\end{array}$ & $\begin{array}{l}\text { Art. } 4^{o} . \text { Qualquer pessoa, física ou jurídica, poderá formular } \\
\text { consulta por escrito à COGERH, para verificar a possibili- } \\
\text { dade de disponibilização de água bruta. Parágrafo único. A } \\
\text { COGERH responderá ao interessado, informando-o sobre a: } \\
\text { I-obrigatoriedade de: } \\
\text { a) obter, junto à SRH, a outorga de direito de uso da água;... } \\
\text { e) custear o conjunto dos instrumentos de medição da água } \\
\text { bruta a serem instalados na unidade usuária, conforme espe- } \\
\text { cificações definidas pela COGERH; } \\
\text { f) instalação pelo interessado, na forma exigida pela CO- } \\
\text { GERH, em locais apropriados e de livre acesso, de caixas ou } \\
\text { cubículos destinados à instalação de hidrômetros elou outros } \\
\text { equipamentos responsáveis pela medição do volume utili- } \\
\text { zado. }\end{array}$ \\
\hline DF & $\begin{array}{l}\text { Adasa - Agência } \\
\text { Reguladora de Água, } \\
\text { Energia e Sanea- } \\
\text { mento Básico do } \\
\text { Distrito Federal }\end{array}$ & $\begin{array}{c}\text { Decreto } \\
\mathrm{n}^{\circ} 22.359 \\
(\text { Distrito Fe- } \\
\text { deral, 2001). }\end{array}$ & $\begin{array}{l}\text { Art. 27. Para permitir o controle do uso de recursos hídricos, } \\
\text { a Secretaria de Meio Ambiente e Recursos Hídricos poderá } \\
\text { exigir que o outorgado instale e opere equipamentos hidro- } \\
\text { métricos. }\end{array}$ \\
\hline
\end{tabular}




\begin{tabular}{|c|c|c|c|}
\hline Estado & $\begin{array}{l}\text { Órgão Gestor de Re- } \\
\text { cursos Hídricos }\end{array}$ & $\begin{array}{l}\text { Referência } \\
\text { Legal }\end{array}$ & $\begin{array}{l}\text { Exigências quanto ao } \\
\text { monitoramento da vazão outorgada }\end{array}$ \\
\hline ES & $\begin{array}{l}\text { Iema - Instituto Es- } \\
\text { tadual de Meio Am- } \\
\text { biente e Recursos } \\
\text { Hídricos }\end{array}$ & \begin{tabular}{|c|} 
Instrução \\
Normativa \\
$\mathrm{n}^{\circ} 019$ \\
(Espírito \\
Santo, 2005) \\
\end{tabular} & $\begin{array}{l}\text { Não foi identificada exigência alguma quanto à instalação de } \\
\text { equipamento ou monitoramento da vazão outorgada. }\end{array}$ \\
\hline GO & $\begin{array}{l}\text { Semarh - Secretaria } \\
\text { do Meio Ambiente e } \\
\text { dos Recursos Hídri- } \\
\text { cos }\end{array}$ & \begin{tabular}{|c|} 
Resolução \\
Cerhi n 09 \\
(Goiás, 2005)
\end{tabular} & $\begin{array}{l}\text { Art. 28. A Secretaria do Meio Ambiente e dos Recursos Hí- } \\
\text { dricos do Estado de Goiás poderá determinar que os outor- } \\
\text { gados instalem e operem estações e equipamentos hidromé- } \\
\text { tricos, promovam estudos de caráter hidrológico, ou a reem- } \\
\text { bolsem dos respectivos custos, ficando obrigados a encami- } \\
\text { nhar-lhe os dados observados e medidos, na forma preconi- } \\
\text { zada no ato de outorga e de conformidade com as normas e } \\
\text { procedimentos por ele estabelecidos. }\end{array}$ \\
\hline MA & $\begin{array}{l}\text { Sema - Secretaria de } \\
\text { Estado do Meio Am- } \\
\text { biente e Recursos } \\
\text { Naturais } \\
\end{array}$ & $\begin{array}{c}\text { Lei no } 8.149 \\
\text { (Maranhão, } \\
\text { 2004) }\end{array}$ & $\begin{array}{l}\text { Não foi identificado decreto que regulamenta a Lei, nem ins- } \\
\text { trução normativa ou resolução do órgão gestor. }\end{array}$ \\
\hline MG & $\begin{array}{l}\text { Igam - Instituto Mi- } \\
\text { neiro de Gestão das } \\
\text { Águas }\end{array}$ & 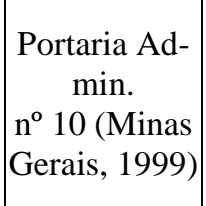 & $\begin{array}{l}\text { Art. } 12 \text { - Determinar que toda outorga sempre que tecnica- } \\
\text { mente indicada e a critério do IGAM, somente seja conce- } \\
\text { dida, em princípio, se o usuário implantar e operar, às suas } \\
\text { expensas, equipamentos de monitoração de acordo com reco- } \\
\text { mendaçốes da Diretoria Controle das Águas do IGAM. }\end{array}$ \\
\hline MS & $\begin{array}{l}\text { Imasul - Instituto de } \\
\text { Meio Ambiente do } \\
\text { Mato Grosso do Sul }\end{array}$ & \begin{tabular}{|l|} 
Lei no $^{\circ} .406$ \\
$($ Mato Grosso \\
do Sul, 2002)
\end{tabular} & $\begin{array}{l}\text { Não foi identificado decreto que regulamenta a Lei, nem ins- } \\
\text { truçãao normativa ou resolução do órgão gestor. }\end{array}$ \\
\hline MT & $\begin{array}{l}\text { Sema - Secretaria de } \\
\text { Estado do } \\
\text { Meio Ambiente }\end{array}$ & 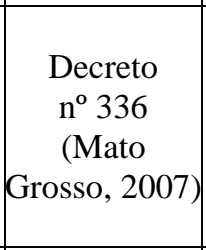 & $\begin{array}{l}\text { Art. 21. São obrigações do outorgado: .... } \\
\text { V- instalar e operar, quando preconizados no ato de ou- } \\
\text { torga, estaçóes e equipamentos de monitoramento hidromé- } \\
\text { trico e de qualidade da água, nas condiçôes especificadas } \\
\text { pela SEMA, encaminhando-lhe os dados medidos e os resul- } \\
\text { tados de análises laboratoriais. }\end{array}$ \\
\hline PA & $\begin{array}{l}\text { Sema - Secretaria de } \\
\text { Estado de Meio Am- } \\
\text { biente }\end{array}$ & \begin{tabular}{|c|} 
Resolução \\
Cerh n'.003 \\
$($ Pará, 2008)
\end{tabular} & $\begin{array}{l}\text { Art. } 23 \text { Os outorgados são obrigados a: ... } \\
\text { III - construir e manter, quando e onde determinado pela au- } \\
\text { toridade outorgante, as instalações necessárias às observa- } \\
\text { ções hidrométricas das águas extraídas e lançadas; }\end{array}$ \\
\hline PB & $\begin{array}{l}\text { Aesa - Agência Exe- } \\
\text { cutiva de Gestão das } \\
\text { Águas do Estado da } \\
\text { Paraíba }\end{array}$ & $\begin{array}{l}\text { Decreto } \\
\mathrm{n}^{\circ} 19.260 \\
\text { (Paraíba, } \\
\text { 1997) }\end{array}$ & $\begin{array}{l}\text { Não foi identificada exigência alguma quanto à instalação de } \\
\text { equipamento ou monitoramento da vazão outorgada. }\end{array}$ \\
\hline PE & $\begin{array}{l}\text { Apac - Agência Per- } \\
\text { nambucana de } \\
\text { Águas e Clima } \\
\end{array}$ & $\begin{array}{c}\text { Lei } \mathrm{n}^{\circ} 12.984 \\
\text { Pernambuco, } \\
\text { 2005) }\end{array}$ & $\begin{array}{l}\text { Não foi identificado decreto que regulamenta a Lei, nem ins- } \\
\text { truçãao normativa ou resolução do órgão gestor. }\end{array}$ \\
\hline PI & $\begin{array}{l}\text { Semar - Secretaria } \\
\text { de Meio Ambiente e } \\
\text { Recursos Naturais }\end{array}$ & $\begin{array}{c}\text { Decreto } \\
\mathrm{n}^{\circ} 11.341 \\
(\text { Piauí, 2004) }\end{array}$ & $\begin{array}{l}\text { Art. } 27 \text { - Quando a análise do pedido de outorga do direito } \\
\text { de uso de recursos hídricos apontar a necessidade de monito- } \\
\text { ramento no ponto de captação, a SEMAR/PI pode exigir do } \\
\text { outorgado, às suas expensas, instalação e operação de esta- } \\
\text { çôes e equipamentos hidrometeorologicos e de qualidade da } \\
\text { água, ou arcar com os respectivos custos quando essas exi- } \\
\text { gências forem implementadas por terceiros. } \\
\text { Parágrafo Único. Quando da instalação e operação das esta- } \\
\text { ções e equipamentos referidos no caput desde artigo, o ou- } \\
\text { torgado deverá fornecer periodicamente à SEMAR/PI todas } \\
\text { as informaçôes coletadas. }\end{array}$ \\
\hline
\end{tabular}




\begin{tabular}{|c|c|c|c|}
\hline Estado & $\begin{array}{l}\text { Órgão Gestor de Re- } \\
\text { cursos Hídricos }\end{array}$ & $\begin{array}{l}\text { Referência } \\
\text { Legal }\end{array}$ & $\begin{array}{l}\text { Exigências quanto ao } \\
\text { monitoramento da vazão outorgada }\end{array}$ \\
\hline PR & $\begin{array}{l}\text { ÁguasParaná - Ins- } \\
\text { tituto das Águas do } \\
\text { Paraná }\end{array}$ & $\begin{array}{c}\text { Decreto } \\
\mathrm{n}^{\mathrm{o}} 4.646, \mathrm{de} \\
31 / 08 / 2001\end{array}$ & $\begin{array}{l}\text { Art. 31. Obriga-se o outorgado a: ... } \\
V \text { - instalar e operar, quando preconizados no ato de outorga } \\
\text { e em outros atos administrativos, estações e equipamentos de } \\
\text { monitoramento hidrométrico e de qualidade da água, nas } \\
\text { condiçôes especificadas pelo Poder Público Outorgante, de } \\
\text { acordo com diretrizes determinadas pelo Manual Técnico de } \\
\text { Outorgas, encaminhando-lhe os dados medidos e os resulta- } \\
\text { dos de análises laboratoriais. }\end{array}$ \\
\hline RJ & $\begin{array}{l}\text { Inea - Instituto Es- } \\
\text { tadual do Ambiente }\end{array}$ & $\begin{array}{c}\text { Portaria Serla } \\
\mathrm{n}^{\circ} 567 \\
(\text { Rio de Ja- } \\
\text { neiro, 2007) }\end{array}$ & $\begin{array}{l}\text { Art. } 24^{\circ} \text { - Do ato administrativo de outorga deverão constar, } \\
\text { no mínimo, as seguintes informações: ... } \\
\text { VII - Obrigação de instalar e manter em funcionamento equi- } \\
\text { pamentos de medição para monitoramento contínuo das va- } \\
\text { zões captadas e lançadas a ser disponibilizadas sempre que } \\
\text { for solicitado pela SERLA; }\end{array}$ \\
\hline $\mathrm{RN}$ & $\begin{array}{l}\text { Semarh - Secretaria } \\
\text { de Estado de Meio } \\
\text { Ambiente e Recur- } \\
\text { sos Hídricos }\end{array}$ & $\begin{array}{c}\text { Decreto } \\
\mathrm{n}^{\circ} 13.283 \\
\text { (Rio Grande } \\
\text { do Norte, } \\
\text { 1997) }\end{array}$ & $\begin{array}{l}\text { Art. } 11 . \S 1^{\circ} \text { - O instrumento de outorga especificará a vazão } \\
\text { máxima outorgada, a obrigatoriedade de o outorgado im- } \\
\text { plantar e manter infraestrutura de medição de água, prazo } \\
\text { de vigência e demais elementos técnico-econômicos relevan- } \\
\text { tes, para caracterizar claramente os direitos e obrigaçôes do } \\
\text { beneficiário. }\end{array}$ \\
\hline RO & $\begin{array}{l}\text { Sedam - Secretaria } \\
\text { de Estado do Desen- } \\
\text { volvimento Ambien- } \\
\text { tal }\end{array}$ & $\begin{array}{c}\text { Decreto } \\
\mathrm{n}^{\circ} 10.114 \\
\text { (Rondônia, } \\
\text { 2002) }\end{array}$ & $\begin{array}{l}\text { Art. 47. A SEDAM poderá determinar que os outorgados ins- } \\
\text { talem e operem estaçóes e equipamentos hidrométricos, pro- } \\
\text { movam estudos de caráter hidrológicos, ou efetuem o reem- } \\
\text { bolso dos respectivos custos, ficando obrigados a encami- } \\
\text { nhar-lhe os dados observados e medidos, na forma preconi- } \\
\text { zada no ato de outorga e em conformidade com as normas e } \\
\text { procedimentos estabelecidos. }\end{array}$ \\
\hline $\mathrm{RR}$ & \begin{tabular}{|l|} 
Femarh - Fundação \\
Estadual do Meio \\
Ambiente e Recur- \\
sos Hídricos de Ro- \\
raima \\
\end{tabular} & $\begin{array}{l}\text { Decreto } \\
\mathrm{n}^{\circ} 8.123-\mathrm{E} \\
(\text { Roraima, } \\
\text { 2003) }\end{array}$ & $\begin{array}{l}\text { Art. 51. Para permitir o controle do uso de recursos hídricos, } \\
\text { a Fundação Estadual do Meio Ambiente, Ciência e Tecnolo- } \\
\text { gia deverá exigir que o outorgado instale e opere equipamen- } \\
\text { tos hidrométricos. }\end{array}$ \\
\hline RS & $\begin{array}{l}\text { DRH - Departa- } \\
\text { mento de Recursos } \\
\text { Hídricos da Secreta- } \\
\text { ria das Obras Públi- } \\
\text { cas, Saneamento e } \\
\text { Habitação }\end{array}$ & \begin{tabular}{|c|} 
Decreto \\
$\mathrm{n}^{\circ} 37.033$ \\
$($ Rio Grande \\
do Sul, 1996)
\end{tabular} & $\begin{array}{l}\text { Art. 20. Serão consideradas Bacias Especiais aquelas em que } \\
\text { a disponibilidade e a demanda estiverem muito próximas, de } \\
\text { acordo com critérios definidos pelo DRH e pela FEPAM. } \\
\text { \$ } 1^{\circ} \text { - A Bacia que for considerada Especial será objeto de } \\
\text { gerenciamento diferenciado que levará em conta, pelo me- } \\
\text { nos: } \\
\text { I- o monitoramento da qualidade e da quantidade dos recur- } \\
\text { sos hídricos, de forma a permitir previsões que orientem o } \\
\text { racionamento ou medidas especiais de controle de deriva- } \\
\text { çôes de águas e de lançamento de efluentes. }\end{array}$ \\
\hline $\mathrm{SC}$ & $\begin{array}{l}\text { SDS - Secretaria de } \\
\text { Estado do Desenvol- } \\
\text { vimento Sustentável }\end{array}$ & $\begin{array}{c}\text { Decreto } \\
\text { n. }{ }^{\circ} 4.778 \\
(\text { Santa Cata- } \\
\text { rina, 2006) }\end{array}$ & $\begin{array}{l}\text { Art. 36. Obriga-se o outorgado a: ... } \\
V-\text { instalar, manter e operar, quando preconizados no ato de } \\
\text { outorga e em outros atos administrativos, estações e equipa- } \\
\text { mentos de monitoramento hidrométrico e de qualidade da } \\
\text { água, nas condições especificadas pelo Órgão Outorgante. }\end{array}$ \\
\hline
\end{tabular}




\begin{tabular}{|c|c|c|c|}
\hline Estado & $\begin{array}{l}\text { Órgão Gestor de } \\
\text { Recursos Hídricos }\end{array}$ & $\begin{array}{l}\text { Referência } \\
\text { Legal }\end{array}$ & $\begin{array}{c}\text { Exigências quanto ao } \\
\text { monitoramento da vazão outorgada }\end{array}$ \\
\hline SE & $\begin{array}{l}\text { Semarh - Secretaria } \\
\text { de Meio Ambiente e } \\
\text { dos Recursos Hídri- } \\
\cos \end{array}$ & $\begin{array}{c}\text { Decreto } \\
\mathrm{n}^{\circ} 18.456 \\
\text { (Sergipe, } \\
\text { 1999). }\end{array}$ & $\begin{array}{l}\text { Art. } 12 . \S 2^{\circ} \text { - O outorgado deve implantar e manter em fun- } \\
\text { cionamento equipamento de medição para monitoramento } \\
\text { contínuo da vazão captada ou lançada. } \\
\text { Art. } 32 \text {. Quando a análise do pedido de outorga do direito de } \\
\text { uso de recursos hídricos apontarem a necessidade de monito- } \\
\text { ramento no ponto de captação, a Seplantec pode exigir do } \\
\text { outorgado, às suas expensas, instalação e operação de esta- } \\
\text { çães e equipamentos hidrometeorológicos e de qualidade da } \\
\text { água, ou arcar com os respectivos custos quando essas exi- } \\
\text { gências forem implementadas por terceiros. } \\
\text { Parágrafo único. Quando da instalação e operação das esta- } \\
\text { çôes e equipamentos referidos no "caput" deste artigo, o ou- } \\
\text { torgado deve se obrigar a fornecer periodicamente, ao poder } \\
\text { público outorgante, todas as informaçôes coletadas. }\end{array}$ \\
\hline SP & $\begin{array}{l}\text { Daee - Departa- } \\
\text { mento de Águas e } \\
\text { Energia Elétrica }\end{array}$ & $\begin{array}{c}\text { Decreto } \\
\mathrm{n}^{\circ} 41.258 \\
\text { (São Paulo, } \\
\text { 1996). }\end{array}$ & $\begin{array}{l}\text { Art. } 6^{\circ} \text { - Obriga-se o outorgado a: ... } \\
\text { VI - instalar e operar estações e equipamentos hidrométricos, } \\
\text { encaminhando ao Departamento de Águas e Energia Elétrica } \\
\text { - DAEE os dados observados e medidos, na forma preconi- } \\
\text { zada no ato de outorga e nas normas de procedimento esta- } \\
\text { belecidas pelo DAEE, mediante portaria do Superintendente } \\
\text { da Autarquia. }\end{array}$ \\
\hline TO & $\begin{array}{l}\text { Naturatins - Insti- } \\
\text { tuto Natureza do To- } \\
\text { cantins }\end{array}$ & $\begin{array}{c}\text { Decreto } \\
\mathrm{n}^{\circ} 2.432 \\
\text { (Tocantins, } \\
2005)\end{array}$ & $\begin{array}{l}\text { Art. 21. A outorga do direito de uso de recursos hídricos } \\
\text { obriga o outorgado: ... } \\
\text { IV - instalar, manter e operar: ... } \\
\text { b) estaçóes e equipamentos de monitoramento hidrométrico e } \\
\text { de qualidade da água, encaminhando ao NATURATINS os } \\
\text { dados medidos e os resultados de análises laboratoriais; }\end{array}$ \\
\hline
\end{tabular}




\section{APÊNDICE B - PLANILHAS DE CONTROLE DE VOLUME}

Planilha de Controle Nível 1 - MONITORAMENTO SIMPLIFICADO

\section{Ano de referência:}

\begin{tabular}{|l|r|r|l|l|}
\hline Nome/Razão Social: & \multicolumn{3}{l|}{ CPF/CNPJ: } \\
\hline$N^{\circ}$ Cadastro: & $N^{\circ}$ Outorga: & & Órgão: & \\
\hline Ponto de interferência: & \multicolumn{5}{|l|}{ Tipo: $\square$ Captação $\square$ Lançamento } \\
\hline Vazão máxima de projeto: & $\mathrm{m}^{3} / \mathrm{h}$ & DBO máxima de projeto: & $\mathrm{mg} / \mathrm{l}$ \\
\hline
\end{tabular}

\begin{tabular}{|c|c|}
\hline Data: & Horas de uso \\
\hline $1 /$ & \\
\hline 11 & \\
\hline / I & \\
\hline $1 /$ & \\
\hline $1 \quad 1$ & \\
\hline $1 \quad 1$ & \\
\hline 11 & \\
\hline 11 & \\
\hline $1 \quad 1$ & \\
\hline 11 & \\
\hline 11 & \\
\hline / I & \\
\hline 11 & \\
\hline 11 & \\
\hline 11 & \\
\hline
\end{tabular}

\begin{tabular}{|c|c|}
\hline Data: & Horas de uso \\
\hline 11 & \\
\hline 11 & \\
\hline 11 & \\
\hline $1 /$ & \\
\hline 11 & \\
\hline 11 & \\
\hline $1 /$ & \\
\hline 11 & \\
\hline 11 & 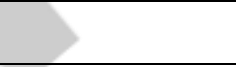 \\
\hline 11 & \\
\hline 11 & \\
\hline 11 & \\
\hline $1 /$ & \\
\hline 11 & \\
\hline $1 \quad 1$ & \\
\hline
\end{tabular}

\begin{tabular}{|c|c|}
\hline Data: & Horas de uso \\
\hline 11 & \\
\hline 11 & $W$ \\
\hline 11 & \\
\hline 11 & \\
\hline 11 & \\
\hline 11 & \\
\hline $1 /$ & \\
\hline 11 & \\
\hline $1 /$ & \\
\hline $1 /$ & \\
\hline 11 & \\
\hline $1 \quad 1$ & \\
\hline $1 /$ & \\
\hline 11 & \\
\hline $1 /$ & \\
\hline
\end{tabular}

TOTAL MENSAL: Preenchimento obrigatório

\begin{tabular}{|l|c|c|}
\hline \multicolumn{1}{|c|}{ Mês } & $\begin{array}{c}\text { Total de } \\
\text { Uso (horas) }\end{array}$ & $\begin{array}{c}\text { Volume } \\
\text { Mensal }\left(\mathbf{m}^{3}\right)\end{array}$ \\
\hline Janeiro & & \\
\hline Fevereiro & & \\
\hline Março & & \\
\hline Abril & & \\
\hline Maio & & \\
\hline Junho & & \\
\hline
\end{tabular}

\begin{tabular}{|l|l|l|}
\hline \multicolumn{1}{|c|}{ Mês } & $\begin{array}{c}\text { Total de } \\
\text { Uso (horas) }\end{array}$ & $\begin{array}{c}\text { Volume } \\
\text { Mensal }\left(\mathbf{m}^{3}\right)\end{array}$ \\
\hline Julho & & \\
\hline Agosto & & \\
\hline Setembro & & \\
\hline Outubro & & \\
\hline Novembro & & \\
\hline Dezembro & & \\
\hline \multicolumn{2}{|l|}{ TOTAL ANUAL $\left(\mathbf{m}^{3}\right)$} & \\
\hline
\end{tabular}




\section{Ano de referência:}

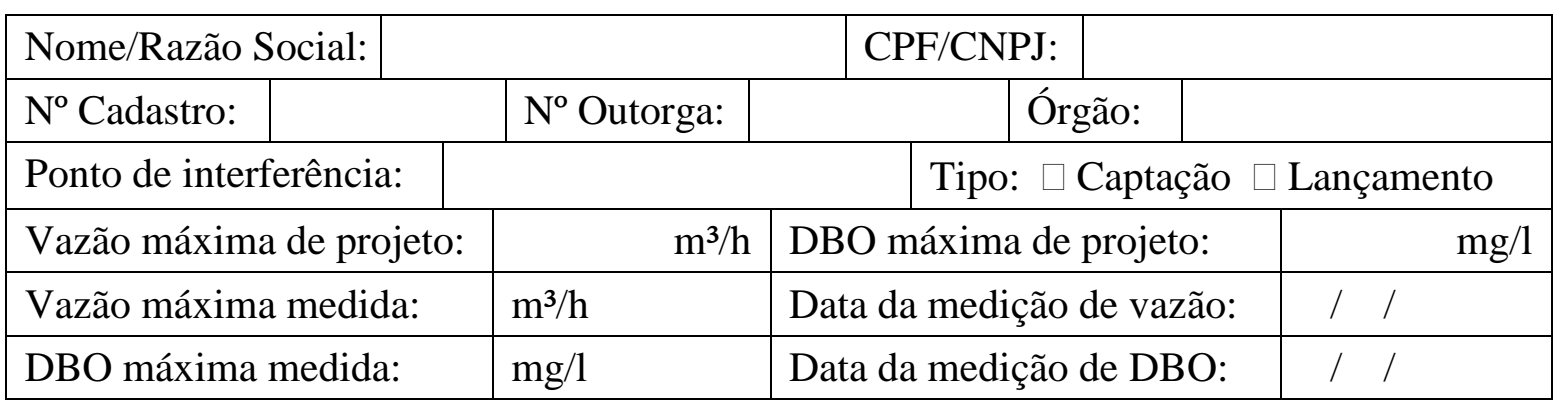

\begin{tabular}{|c|c|}
\hline Data: & Reg. horímetro \\
\hline I I & \\
\hline I I & \\
\hline I I & \\
\hline I I & \\
\hline 11 & \\
\hline I I & \\
\hline 11 & \\
\hline 11 & \\
\hline 11 & \\
\hline 11 & \\
\hline 11 & \\
\hline 11 & \\
\hline 11 & \\
\hline
\end{tabular}

\begin{tabular}{|c|c|}
\hline Data: & Reg. horímetro \\
\hline I I & \\
\hline $1 \quad 1$ & \\
\hline I I & \\
\hline 11 & \\
\hline $1 \quad 1$ & \\
\hline I I & \\
\hline $1 \quad 1$ & \\
\hline $1 \quad 1$ & \\
\hline I I & \\
\hline I I & \\
\hline $1 \quad 1$ & \\
\hline I I & \\
\hline $1 \quad 1$ & \\
\hline
\end{tabular}

\begin{tabular}{|c|c|}
\hline Data: & Reg. horímetro \\
\hline 11 & \\
\hline 11 & \\
\hline 11 & \\
\hline 11 & \\
\hline 11 & \\
\hline 11 & \\
\hline 11 & \\
\hline 11 & \\
\hline I I & \\
\hline 11 & \\
\hline 11 & \\
\hline 11 & \\
\hline 11 & \\
\hline
\end{tabular}

TOTAL MENSAL: Preenchimento obrigatório

\begin{tabular}{|l|l|l|}
\hline \multicolumn{1}{|c|}{ Mês } & $\begin{array}{c}\text { Total de } \\
\text { Uso (horas) }\end{array}$ & $\begin{array}{c}\text { Volume } \\
\text { Mensal }\left(\mathbf{m}^{\mathbf{3}}\right)\end{array}$ \\
\hline Janeiro & & \\
\hline Fevereiro & & \\
\hline Março & & \\
\hline Abril & & \\
\hline Maio & & \\
\hline Junho & & \\
\hline
\end{tabular}

\begin{tabular}{|l|l|l|}
\hline \multicolumn{1}{|c|}{ Mês } & $\begin{array}{c}\text { Total de } \\
\text { Uso (horas) }\end{array}$ & $\begin{array}{c}\text { Volume } \\
\text { Mensal }\left(\mathbf{m}^{3}\right)\end{array}$ \\
\hline Julho & & \\
\hline Agosto & & \\
\hline Setembro & & \\
\hline Outubro & & \\
\hline Novembro & & \\
\hline Dezembro & & \\
\hline \multicolumn{2}{|l|}{ TOTAL ANUAL $\left(\mathbf{m}^{3}\right)$} & \\
\hline
\end{tabular}


Planilha de Controle Nível 3 - MONITORAMENTO AVANÇADO

Ano de referência:

\section{DAURH}

Declaração Anual de Uso de Recursos Hídricos

\begin{tabular}{|l|r|l|l|l|}
\hline Nome/Razão Social: & \multicolumn{2}{l|}{ CPF/CNPJ: } \\
\hline No Cadastro: & $N^{\circ}$ Outorga: & \multicolumn{1}{l|}{ Órgão: } & \\
\hline Ponto de interferência: & \multicolumn{5}{|l|}{ Tipo: $\square$ Captação $\square$ Lançamento } \\
\hline Vazão máxima de projeto: & $\mathrm{m}^{3} / \mathrm{h}$ & DBO máxima de projeto: & $\mathrm{mg} / \mathrm{l}$ \\
\hline Vazão máxima medida: & $\mathrm{m}^{3} / \mathrm{h}$ & Data da medição de vazão: & $/ /$ \\
\hline DBO máxima medida: & $\mathrm{mg} / \mathrm{l}$ & Data da medição de DBO: & $/ /$ \\
\hline
\end{tabular}

\begin{tabular}{|c|c|}
\hline Data: & $\begin{array}{l}\text { Registro do volume } \\
\text { medido }\left(\mathrm{m}^{3}\right)\end{array}$ \\
\hline 11 & \\
\hline 11 & \\
\hline 11 & \\
\hline 11 & \\
\hline 11 & \\
\hline 11 & \\
\hline 11 & \\
\hline 11 & \\
\hline 11 & \\
\hline 11 & \\
\hline 11 & \\
\hline 11 & \\
\hline 11 & \\
\hline
\end{tabular}

\begin{tabular}{|c|c|}
\hline Data: & $\begin{array}{l}\text { Registro do volume } \\
\text { medido }\left(\mathrm{m}^{3}\right)\end{array}$ \\
\hline 11 & \\
\hline 11 & \\
\hline 11 & \\
\hline 11 & \\
\hline 11 & \\
\hline 11 & \\
\hline 11 & \\
\hline 11 & \\
\hline 11 & \\
\hline 11 & \\
\hline 11 & \\
\hline 11 & \\
\hline 11 & \\
\hline
\end{tabular}

\begin{tabular}{|c|c|}
\hline Data: & $\begin{array}{l}\text { Registro do volume } \\
\text { medido }\left(\mathrm{m}^{3}\right)\end{array}$ \\
\hline 11 & \\
\hline 11 & \\
\hline 11 & \\
\hline 11 & \\
\hline 11 & \\
\hline 11 & \\
\hline 11 & \\
\hline 11 & \\
\hline 11 & \\
\hline 11 & \\
\hline 11 & \\
\hline 11 & \\
\hline 11 & \\
\hline
\end{tabular}

TOTAL MENSAL: Preenchimento obrigatório

\begin{tabular}{|l|c|}
\hline \multicolumn{1}{|c|}{ Mês } & $\begin{array}{c}\text { Volume Mensal } \\
\left(\text { medição em m } \text { m }^{3}\right.\end{array}$ \\
\hline Janeiro & \\
\hline Fevereiro & \\
\hline Março & \\
\hline Abril & \\
\hline Maio & \\
\hline Junho & \\
\hline
\end{tabular}

\begin{tabular}{|l|l|}
\hline \multicolumn{1}{|c|}{ Mês } & \multicolumn{1}{c|}{$\begin{array}{c}\text { Volume Mensal } \\
\text { (medição em m } \text { m }^{\mathbf{3}} \text { ) }\end{array}$} \\
\hline Julho & \\
\hline Agosto & \\
\hline Setembro & \\
\hline Outubro & \\
\hline Novembro & \\
\hline Dezembro & \\
\hline TOTAL $\left(\mathbf{m}^{3}\right)$ & \\
\hline
\end{tabular}




\section{APÊNDICE C - PROJETO-PILOTO NA BACIA DO RIBEIRÃO PIPIRIPAU}

Como parte complementar para recomendações quanto à instalação dos equipamentos de medição de vazão, para composição do SSD, faz-se necessário o entendimento dos processos de medição de vazões em superfícies livres e condutos forçados, mediante a verificação de funcionamento de equipamentos de medição de vazão instalados na bacia hidrográfica do ribeirão Pipiripau (DF/GO).

O projeto-piloto na bacia hidrográfica do ribeirão Pipiripau (DF/GO) envolve a contratação de empresa privada, pela Agência Nacional de Águas, para prestação de serviços técnicos especializados de engenharia num período de três anos. Os serviços de engenharia se constituem de instalação de estações hidrométricas (de medição de vazão) de uso de recursos hídricos, contemplando a instalação, automação, operação, manutenção, análise comparativa e a verificação da eficiência de diversos sistemas de medição de vazão e volume de água bruta e sua integração com a base de dados da ANA.

Foram instalados diversos equipamentos de medição de vazão em 5 (cinco) estações hidrométricas na bacia do Pipiripau. Os resultados desse estudo experimental são apresentados no Apêndice C da presente dissertação.

Aliado aos estudos experimentais, para composição dos dados de equipamentos de medição para o SSD, considerou-se os estudos teóricos e o referencial bibliográfico constante do item 3.3 - "Sobre os equipamentos de medição". Foram utilizados livros, artigos e catálogos de fabricantes, bem como consulta aos preços de mercados e normas existentes para instalação, para composição final dos processos de medições de vazões.

O projeto-piloto na bacia hidrográfica do ribeirão Pipiripau (DF/GO) envolve a contratação de empresa privada, pela Agência Nacional de Águas, para prestação de serviços técnicos especializados de engenharia num período de três anos. Os serviços de engenharia se constituem de instalação de estações hidrométricas de uso de recursos hídricos, contemplando a instalação, automação, operação, manutenção, análise comparativa e a verificação da eficiência de diversos sistemas de medição de vazão e volume de água bruta e sua integração com a base de dados da ANA.

O contrato da ANA com a empresa especializada denominada Vector Engenharia e Sistemas de Automação foi firmado em novembro de 2011, em virtude de licitação, do tipo concorrência, modalidade menor preço através de empreitada integral. 
O ribeirão Pipiripau, corpo hídrico de domínio da União, tem sua nascente localizada nos limites do Município de Formosa - GO, estendendo-se pela porção nordeste do Distrito Federal, vindo a formar o rio São Bartolomeu, bacia hidrográfica do Paraná. A bacia do ribeirão Pipiripau compreende uma área de drenagem de aproximadamente $235 \mathrm{~km}^{2}$. A maior parte da área da bacia está inserida no Distrito Federal (90,3\%), sendo que em Goiás encontram-se as nascentes mais a montante da bacia (Chaves\&Piau, 2008).

A bacia do Pipiripau possui pouca disponibilidade hídrica para os usos instalados. Em busca de solução dos conflitos pelo uso da água instalados na região, a ANA publicou a Resolução n ${ }^{\circ} 127$, de 3 de abril de 2006, estabelecendo o marco regulatório de procedimentos e critérios de outorga de direito de uso de recursos hídricos na bacia do ribeirão Pipiripau (Brasil, 2006a). Destaca-se, na Resolução 127/2006, a criação de 5 (cinco) Pontos de Controle onde são monitoradas condições de vazões mínimas remanescentes que verificam a disponibilidade hídrica na bacia, em termos quantitativos.

Os usuários de domínio da União da bacia do ribeirão Pipiripau, localizados no Distrito Federal, são outorgados pela Agência Reguladora de Águas, Energia e Saneamento Básico do Distrito Federal ADASA, uma vez que a ANA delegou a competência das outorgas dos rios federais àquela agência pela Resolução ${ }^{\circ}$ 77, de 22 de março de 2010 (Brasil, 2010b).

Além dos usuários de domínio da União, a ADASA também outorga o uso de recursos hídricos aos usuários que utilizam corpos hídricos de domínio do Distrito Federal na bacia do ribeirão Pipiripau, como o rio Taquara, por exemplo, bem como os poços instalados (água subterrânea). As outorgas da ADASA são individuais, emitidas nos meses de novembro e dezembro de 2012 por intermédio de portarias e resoluções, com vigência de 5 anos, ou seja, válidas até o final de 2017 (Distrito Federal, 2012a).

A parte goiana da bacia representa menos de $10 \%$ da área. Nesta região, a própria ANA analisa e emite as outorgas dos usuários de domínio da União, uma vez que não há delegação de outorga da Agência à Secretaria do Meio Ambiente e dos Recursos Hídricos do Estado de Goiás - SEMARH, órgão gestor de recursos hídricos daquele estado. Em relação aos usuários de domínio do Estado de Goiás, não foram constatadas outorgas pelo referido órgão gestor.

Dessa forma, entre usuários de domínio da União e do Distrito Federal, 116 usuários estão outorgados na bacia, totalizando 173 pontos de interferência. O volume total outorgado - e em vigência até 2017 - é de 1195 l/s. 
Segundo informações da fiscalização da ANA, nos anos de 2007, 2008, 2009, 2011 e 2014, durante o período de seca em Brasília - julho a outubro - foram observados valores inferiores às vazões remanescentes. Tal fato provocou a realização de reuniões da Comissão de Acompanhamento instituída pela Resolução ANA n 127/2006, responsável pelo acompanhamento da gestão dos recursos hídricos da bacia, resultando no estabelecimento de medidas de racionamento, como revezamento de horário de captação dos usuários (Brasil, 2006a).

Para melhoria na gestão dos recursos hídricos da bacia, além de se realizar o monitoramento da disponibilidade hídrica pelos Pontos de Controle, é muito importante se conhecer a real demanda na bacia. Daí a importância, para a ANA, da instalação de equipamentos de medição nos usuários da bacia e o conhecimento das informações dos volumes captados.

Além disso, e não menos importante, a escolha da bacia do Pipiripau se dá pela proximidade da mesma à sede da ANA, em Brasília, onde está lotada a Superintendência de Fiscalização - SFI, responsável pelo acompanhamento técnico e pela gestão do contrato com a empresa Vector. Dessa forma, a SFI pode acompanhar o trabalho de perto e com maior frequência, desde a montagem dos equipamentos até o funcionamento dos sistemas, economizando custos com deslocamentos, passagens e diárias.

Por razões de racionalidade, foram escolhidos para o projeto-piloto 5 (cinco) usuários da bacia para monitoramento, a saber: Antônio Mazurek (estação 1), Campos Agrícola Ltda. - Areal (estação 2), Geraldo Magela (estação 3), CAESB (estação 4) e Canal de Irrigação Santos Dumont (estação 5). Em termo de significância, a soma dos volumes outorgados para esses usuários é significativa, pois representa $64 \%$ do total outorgado na bacia.

O projeto-piloto prevê ainda um ponto de apoio na EMATER, onde uma estação central (Estação 06) foi instalada para a recepção e retransmissão para a ANA dos dados obtidos nas cinco estações de medição.

A seguir, apresentam-se duas figuras: a Figura 4.1 representa um plano altimétrico da bacia do ribeirão Pipiripau, com a localização das 6 Estações; e a Figura 4.2 mostra um esquema geral da arquitetura do sistema de medição instalado na referida bacia. 


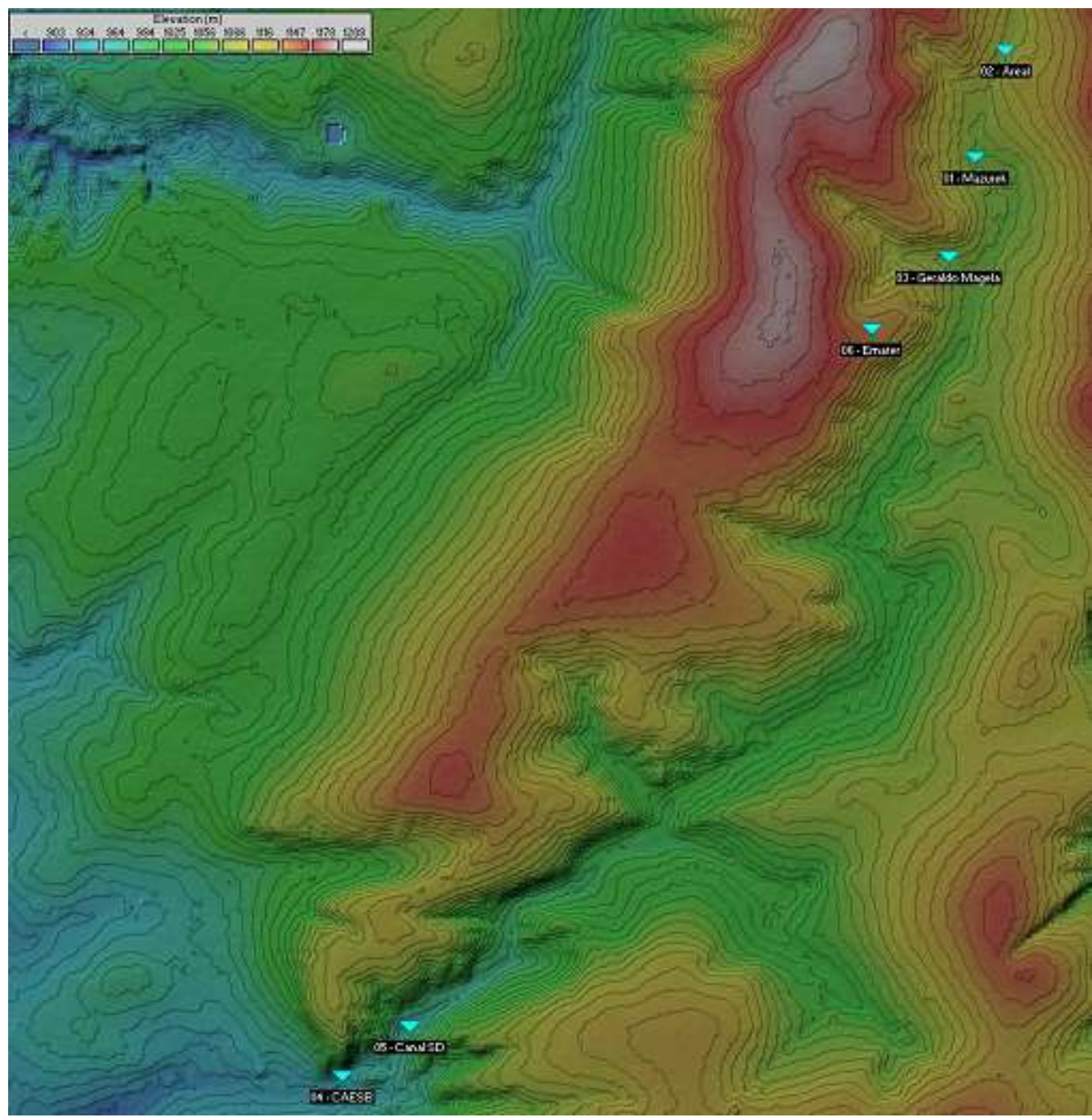

Figura C.1 - Localização das estações hidrométricas - Cortesia: Vector

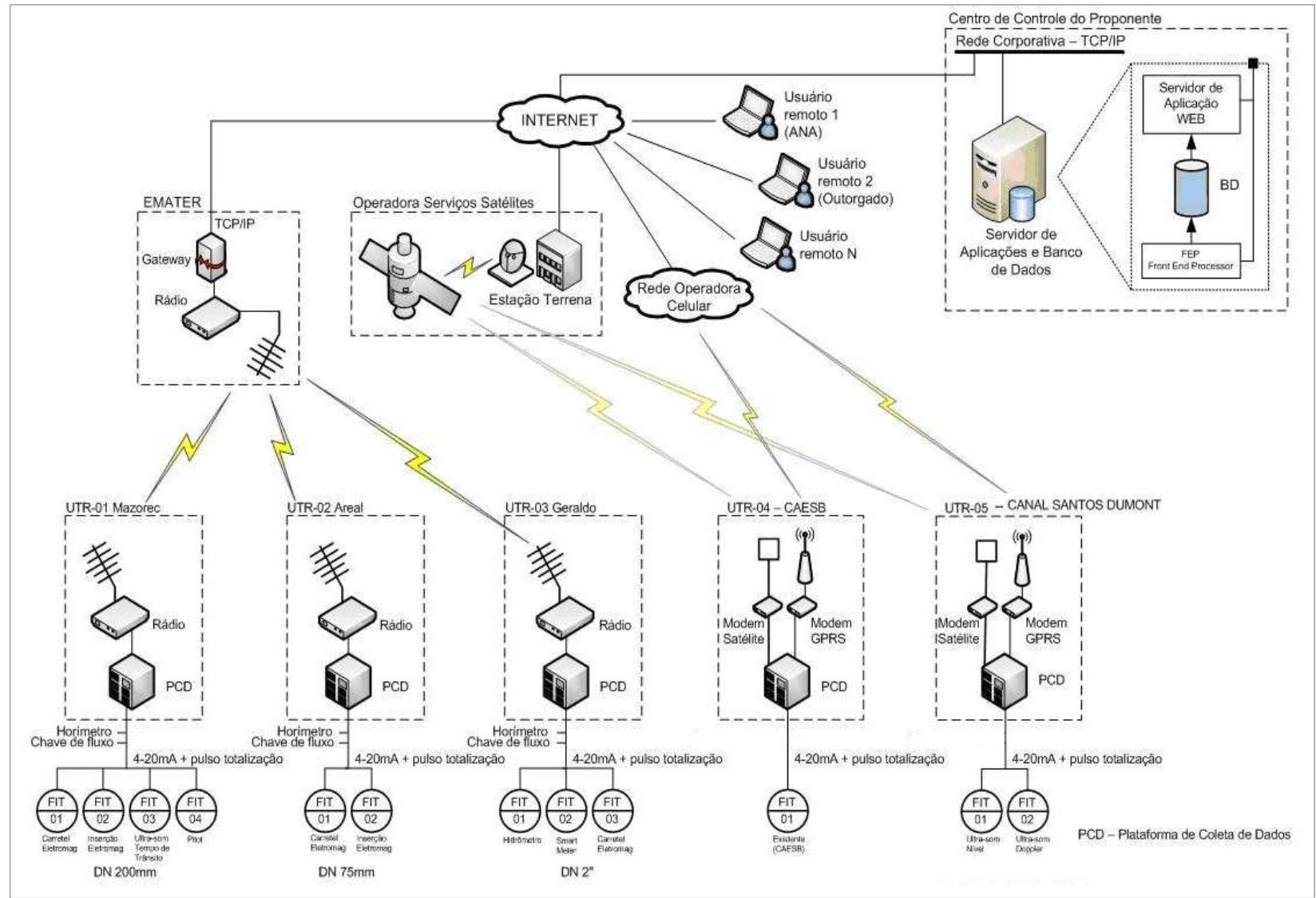

Figura C.2 - Arquitetura geral do sistema com as 5 Estações de medição - Cortesia: Vector 


\section{C.1 ESTAÇÕES DE MEDIÇÃO}

Apresentam-se, a seguir, as estações hidrométricas e os equipamentos instalados:

\section{C.1.1 Estação 1: Antônio Mazurek}

A propriedade do Sr. Antônio Mazurek é a única em toda a bacia que utiliza pivô central para irrigação de café. Dessa forma, é o principal usuário individual irrigação na bacia, com 36,5 1/s de vazão outorgada, representando 3\% do volume total outorgado na bacia. Possui o único pivô central instalado na bacia.

Para realização da captação de água para abastecer o pivô, o usuário utiliza um conjunto motor-bomba que leva água pressurizada por meio de tubulação em chapa de zinco com $200 \mathrm{~mm}$ de diâmetro, tendo sido instalados os seguintes equipamentos:

- Eletromagnético de carretel;

- 2 Eletromagnéticos de inserção (o $1^{\circ}$ foi instalado no período inicial, em novembro de 2013, e o $2^{\circ}$ foi instalado 1 ano depois, em novembro de 2014);

- Medidor de vazão Annubar (espécie de tubo Pitot);

- Horímetro por detector de corrente (instalado dentro da casa de bombas);

- Chave de fluxo (instalada dentro da casa de bombas).

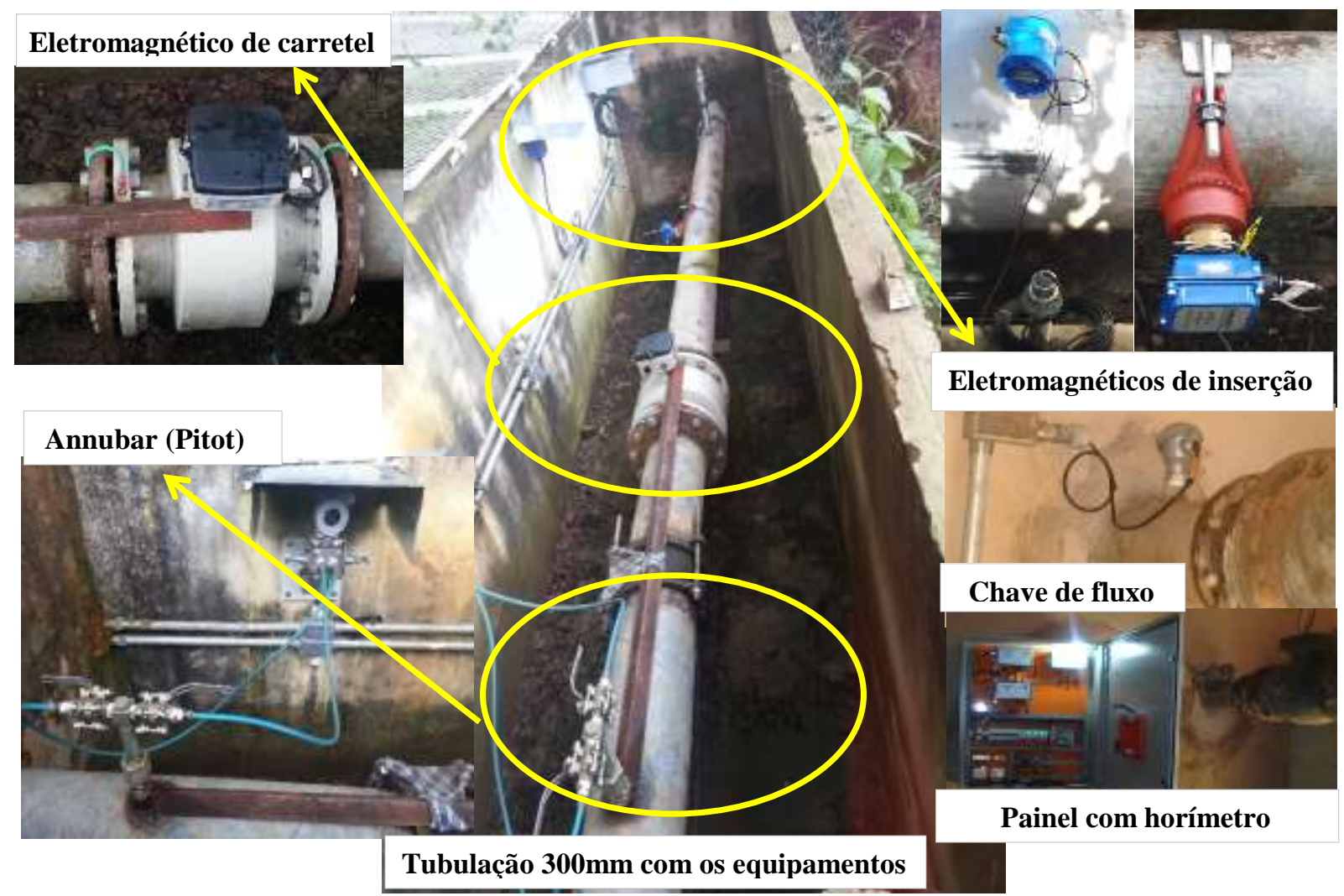

Figura C.3 - Estação 1 Mazurek: tubulação de 300mm para pivô, com equip. instalados. 


\section{C.1.2}

\section{Estação 2: Areal Campos Agrícola LTDA}

Usuário de mineração, retira água do Pipiripau para lavagem e beneficiamento da areia. É o único outorgado de recursos hídricos outorgado diretamente pela ANA, pois se localiza na cabeceira da bacia, no município de Formosa/GO. Cabe aqui informar que não há delegação de outorga da ANA para o órgão gestor de recursos hídricos do Estado de Goiás.

A propriedade é do Sr. Zanquetti e possui outorga de 15,3 1/s, o que representa 1,3\% do volume outorgado. O ponto de captação é formado por um conjunto motor-bomba que leva água pressurizada por meio de tubulação em ferro galvanizado, com $75 \mathrm{~mm}$ de diâmetro. Neste ponto, foram instalados os seguintes equipamentos:

- Bocal de vazão;

- Eletromagnético do tipo carretel;

- Eletromagnético de inserção;

- Horímetro por detector de corrente (instalado dentro da casa de bombas);

- Chave de Fluxo (instalada dentro da casa de bombas).

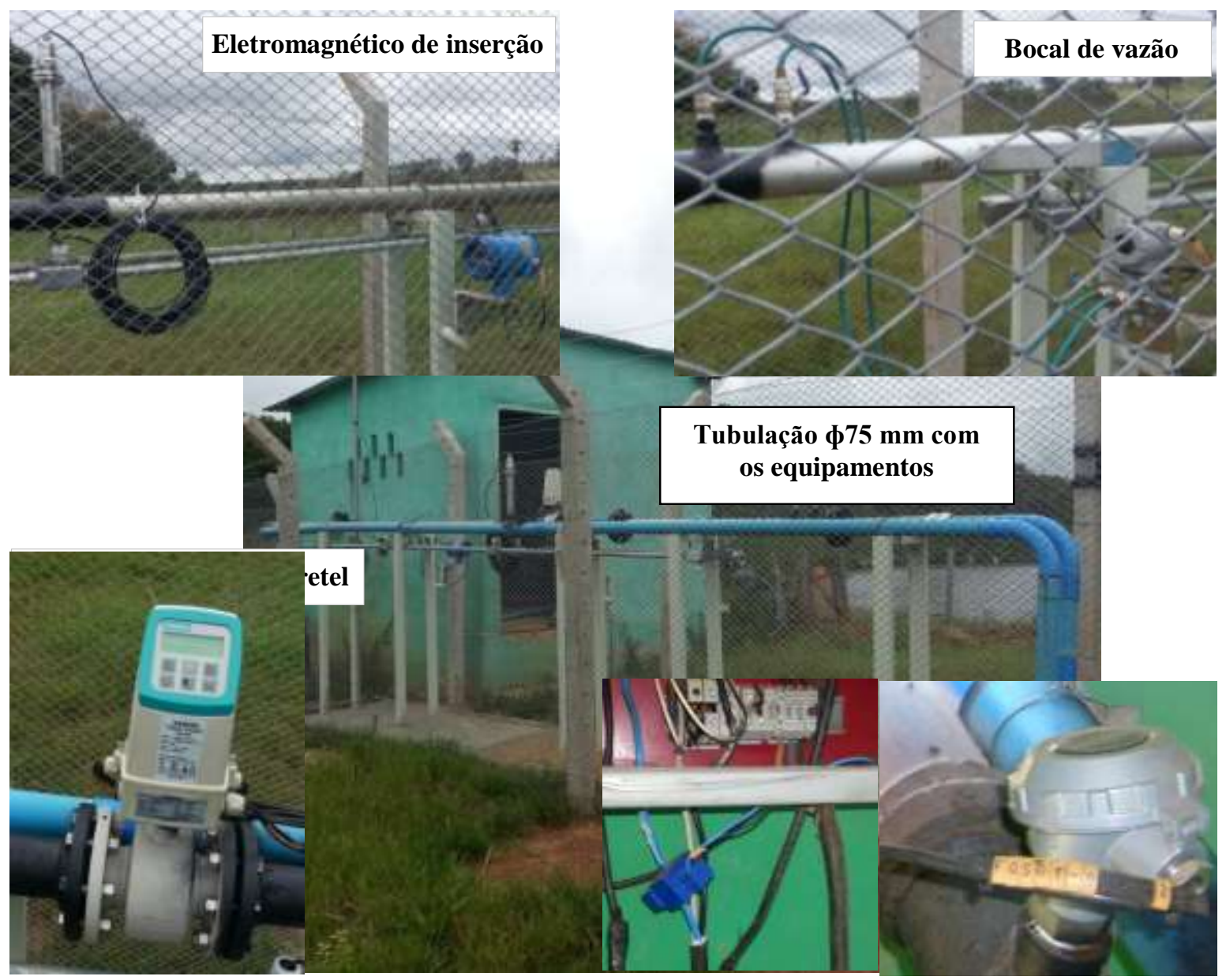

Figura C.4 - Estação 2 - Areal: ponto de captação com tubulação de diâmetro de 75mm e equipamentos instalados. 


\section{C.1.3}

Estação 3: Geraldo Magela

O Sr. Magela utiliza água para plantio de hortaliças irrigando por gotejamento, com captação em tubulação de PVC com diâmetro nominal de 50mm. Possui vazão outorgada de 3,5 1/s, que corresponde a $0,3 \%$ do total autorizado.

A escolha dessa propriedade para estação de medição se deu por dois fatores:

1) Representa a maioria dos usuários da bacia, ou seja, pode ser considerado como um "usuário tipo", uma vez que 80 dos 116 usuários (69\%) possui esse sistema de captação e método de irrigação;

2) O Sr. Magela é funcionário da EMATER do Núcleo Rural Pipiripau, sendo uma pessoa de referência aos demais usuários da região, por trabalhar na área de consultoria técnica.

Para esta estação de medição, foram instalados os seguintes equipamentos:

- Hidrômetro de velocidade tipo Woltmann;

- Eletromagnético de carretel;

- Ultrassônico por tempo de trânsito;

- Horímetro por detector de corrente (instalado dentro da casa de bombas);

- Chave de Fluxo

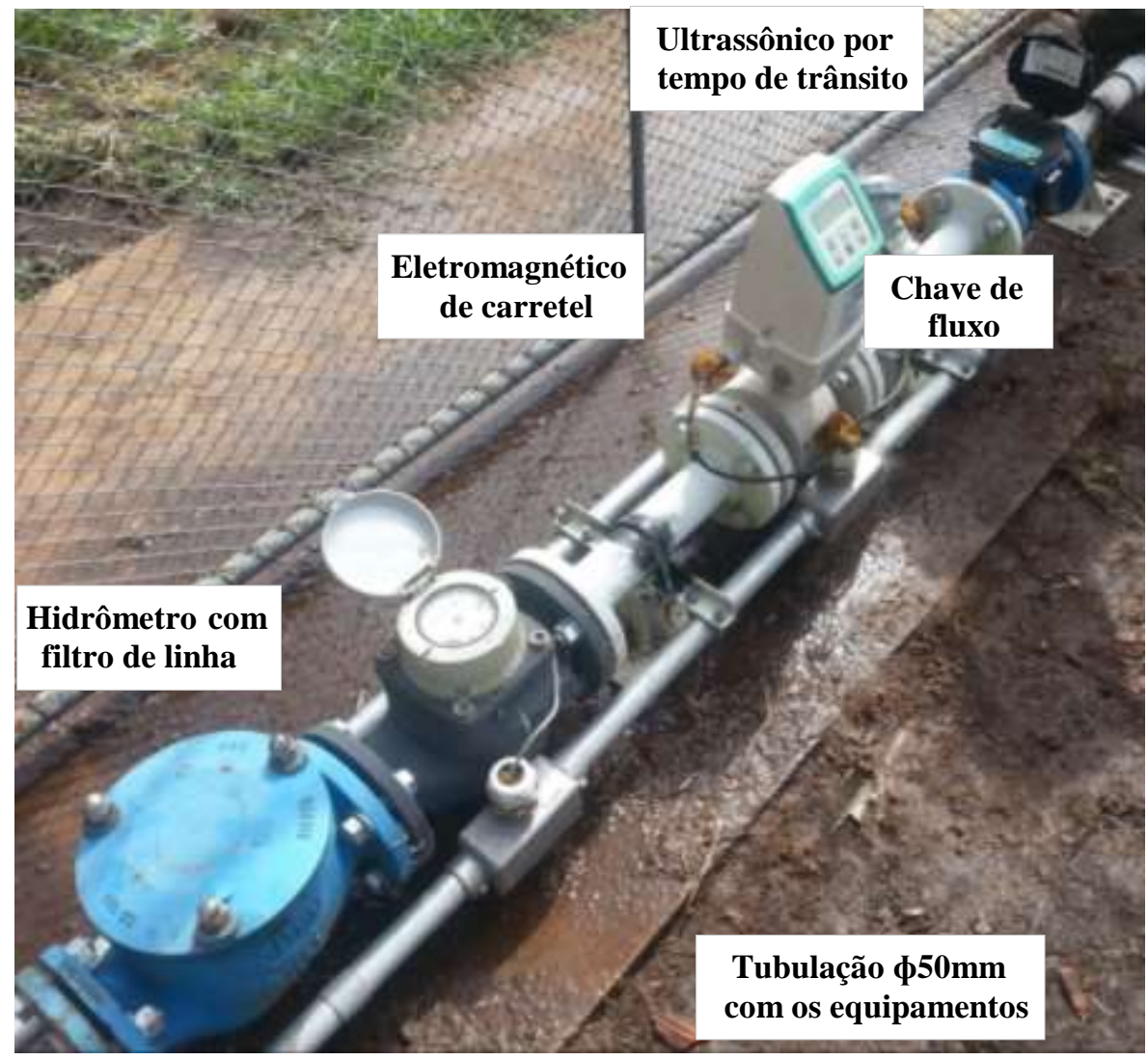

Figura C.5 - Estação 3-Geraldo Magela: tubulação de saída com diâm. 50mm e equip. instalados. 


\section{C.1.4}

\section{Estação 4: CAESB}

A Companhia de Saneamento Ambiental do DF - CAESB possui outorga de 400 1/s, segundo Resolução ADASA n n 9, de 23 de novembro de 2012 (Distrito Federal, 2012b). Esse valor corresponde a $33 \%$ do total outorgado, o maior volume outorgado na bacia. A água captada no ribeirão Pipiripau é aduzida até a estação de tratamento de água denominada ETA Pipiripau, tratada e depois distribuída para abastecimento das Regiões Administrativas de Planaltina e Sobradinho (DF).

O ponto de captação é formado por dois conjuntos motor-bomba que levam água pressurizada por meio de tubulação em ferro fundido, com $700 \mathrm{~mm}$ de diâmetro, existindo ainda um terceiro conjunto motor-bomba de reserva. Há três tipos de funcionamento desse sistema de captação: desligado, com uma bomba ligada ou com as duas bombas ligadas.

A Caesb já possui sistema de medição do tipo eletromagnético de carretel na entrada da ETA Planaltina. Portanto, como já existe um equipamento instalado e, por questões de economicidade do Projeto Piloto, foi realizada a instalação de somente dois novos equipamentos, $100 \mathrm{~m}$ a montante do eletromagnético de carretel já instalado, a saber:

- Eletromagnético de inserção;

- Ultrassônico por tempo de trânsito.

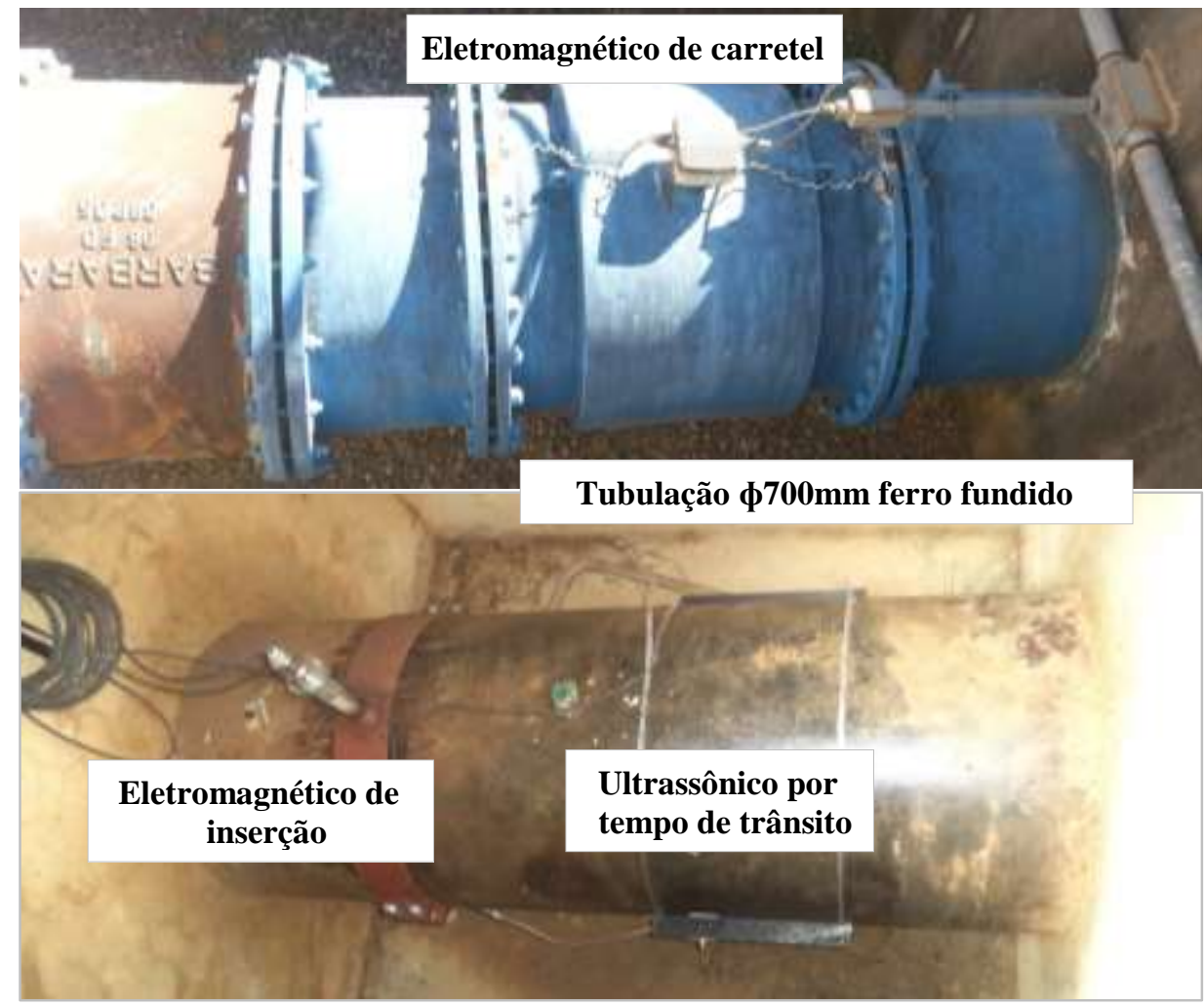

Figura C.6 - Estação 4 CAESB: tubulação de 700mm de diâmetro: acima, equipamento da CAESB já instalado; abaixo, dois equipamentos instalados pelo projeto piloto 


\section{C.1.5}

Estação 5: Canal Santos Dumont

A Associação de Usuários do Canal de Abastecimento de Água do Núcleo Rural Santos Dumont possui outorga sazonal, com vazão máxima instantânea de 327 1/s, segundo Resolução ADASA nº 06, de 23 de novembro de 2012 (Distrito Federal, 2012c). O volume outorgado corresponde a 27\% do total disponível na bacia para outorga - o segundo maior em volume.

A associação possui ponto de captação por meio de derivação da água do ribeirão Pipiripau, para entrada num canal com o $1^{\circ}$ trecho em concreto de formato retangular, com 1,5 metro de largura e altura máxima de $95 \mathrm{~cm}$. O $2^{\circ}$ trecho é escavado em terra, sem revestimento, com forma trapezoidal, e leva água por gravidade (conduto de superfície livre, sem pressão) até o Núcleo Rural Santos Dumont. Os seguintes equipamentos foram instalados no trecho retangular:

- Calha Parshall pré-fabricada com garganta de 3" (largura da garganta =0,914m) + ultrassônico de nível posicionado em suporte acima da calha;

- Ultrassônico por efeito Doppler no fundo do canal;

- Vertedouro retangular de soleira delgada (1,5m de largura), com chapa de material tipo PRFV (Polietileno reforçado com fibra de vidro) + medidor de nível tipo diferencial de pressão hidrostática (no fundo do canal).
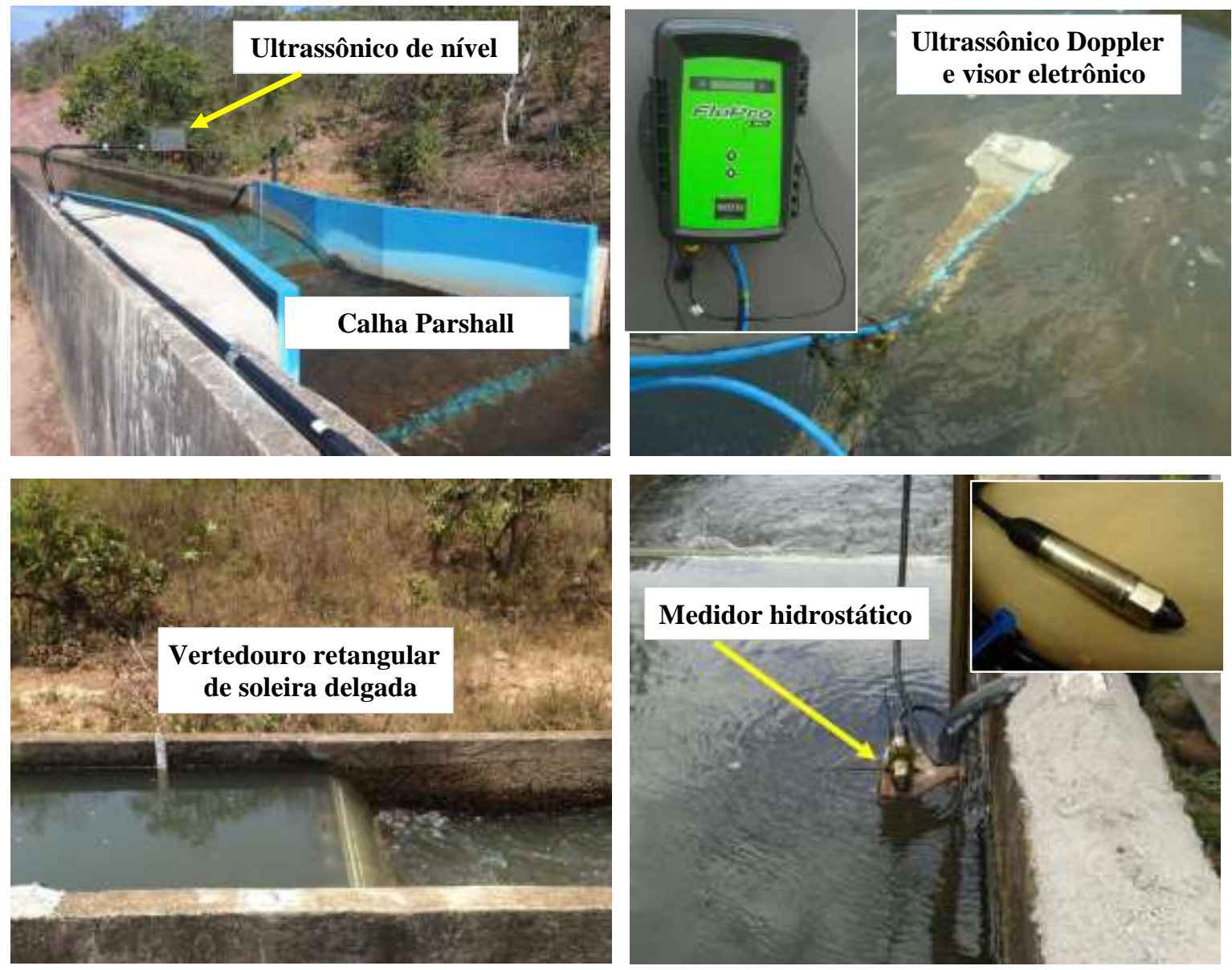

Figura C.7 - Estação 5: Canal de Irrigação Santos Dumont: equipamentos instalados 


\section{C.2 AQUISIÇÃO E ANÁLISE DOS DADOS DO PROJETO-PILOTO}

Os dados de medição de vazão dos equipamentos instalados no Pipiripau, constantes do Projeto Piloto, estão sendo produzidos desde o dia $1^{\circ}$ de novembro de 2013. A obtenção dos mesmos pode ser feita via Webservice, no site http://ana.vector.com.br. O acesso à informação deve ser feito com USUÁRIO:“sfi_ana” e SENHA:"pipiripau”.

Ao acessar o site, aparece um mapa da bacia do Pipiripau, com a localização geográfica das 5 (cinco) Estações Hidrométricas (de medição de vazão), conforme figura a seguir. Ao clicar no número correspondente a cada Estação, abre-se uma janela com os dados de medição de todos os equipamentos referentes à Estação selecionada.

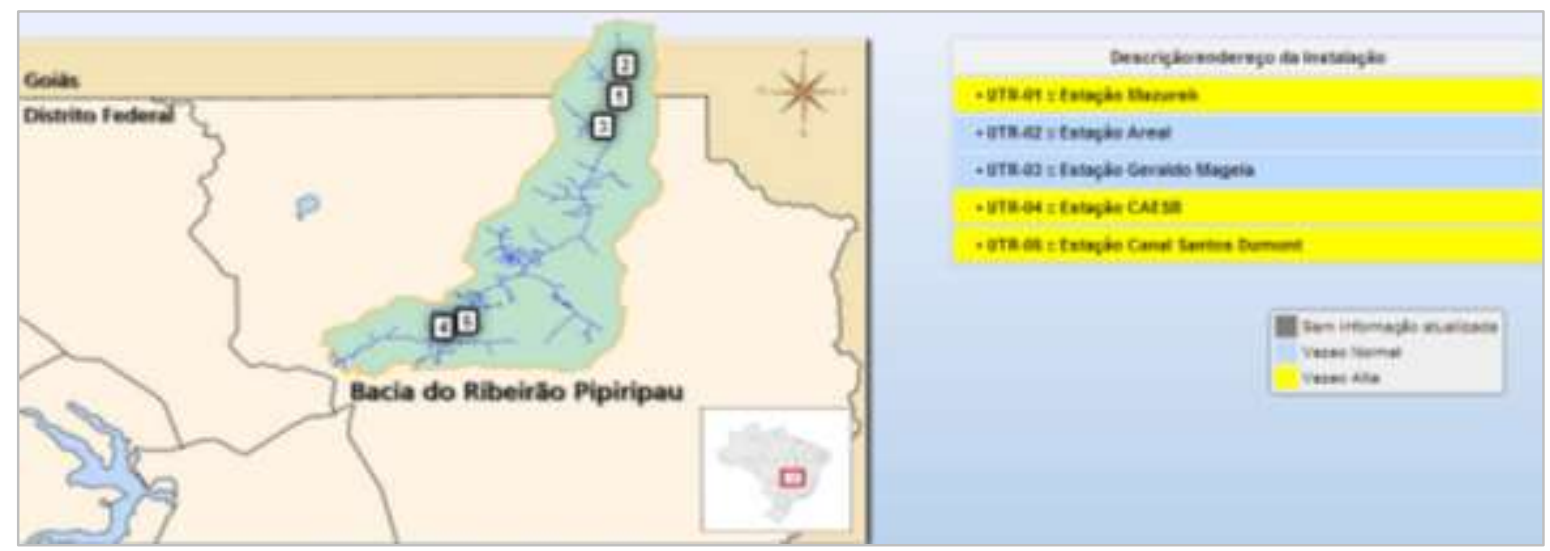

Figura C.8 - Mapa com as 5 Estações Hidrométricas (Fonte: http://ana.vector.com.br)

Clicando-se em uma das 5 (cinco) Estações, visualiza-se uma tela principal, com o esquema de montagem dos equipamentos da Estação selecionada. Na Figura a seguir, apresenta-se a tela principal da Estação 1 - Mazurek, como exemplo.

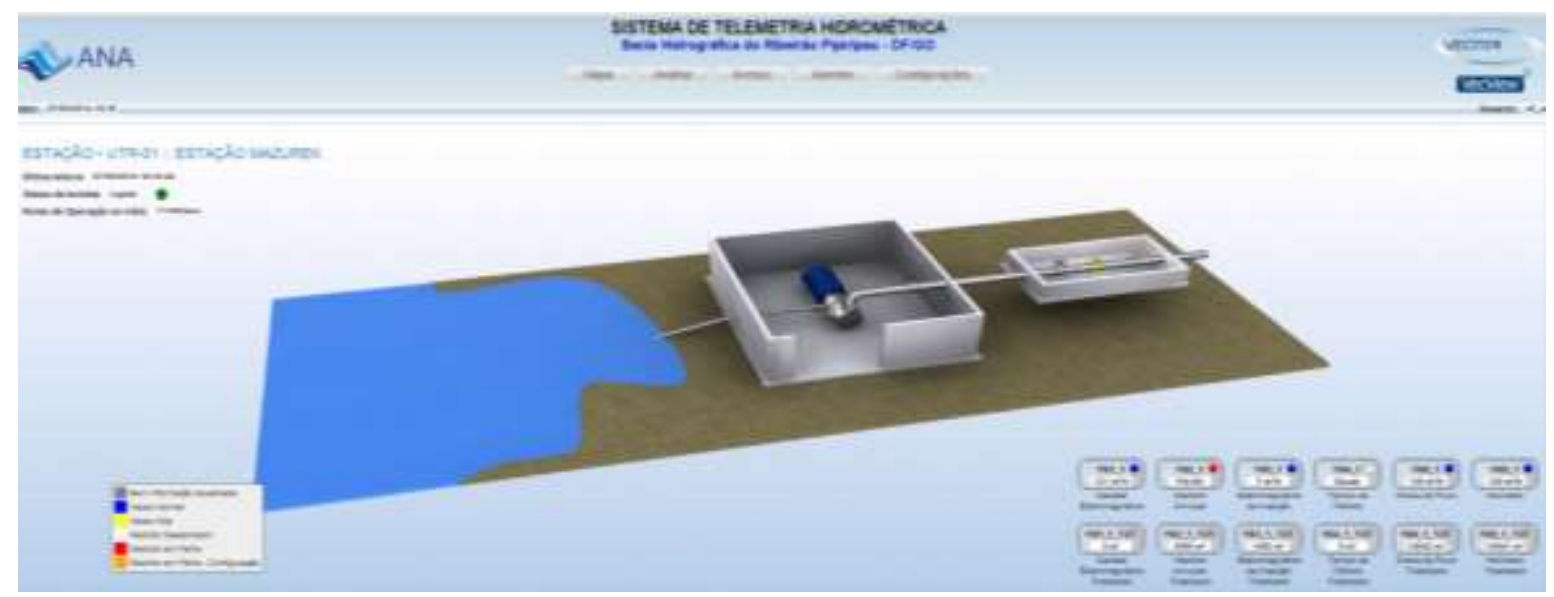

Figura C.9 - Tela principal da Estação Hidrométrica 1 - Mazurek 
Essa tela inicial contém as seguintes informações:

- Nome da Estação;

- Data e hora da última leitura dos medidores de vazão;

- "Status" da bomba: se está ligada ou desligada;

- Vazão instantânea de cada um dos equipamentos de medição de vazão instalados;

- "Status" dos equipamentos de medição: vazão normal (até $80 \%$ do valor outorgado), vazão alta (acima de $80 \%$ do valor outorgado), ou medidor em falha;

- Vazão totalizada de cada um dos equipamentos de medição de vazão instalados.

Dessa tela principal, podem-se visualizar os valores de vazão transmitidos de forma instantânea e totalizados clicando na aba "Análise". Tanto os valores instantâneos quanto os totalizados são dados fornecidos pelos equipamentos, transmitidos via Webservice e disponibilizados no site. Isso quer dizer que o sistema não faz cálculo de totalização dos volumes, são os equipamentos que fazem esses cálculos. O sistema apenas reproduz os valores disponibilizados pelos equipamentos.

As informações de vazão dos equipamentos disponibilizadas em termos instantâneos são registradas com o intervalo de 5 minutos. Os dados são visualizados de duas formas: como tabela, e como gráfico. Segue figura com os dados gráficos e em forma de tabela da vazão instantânea em 14/09/2014, relativos à Estação 3 - Mazurek, como exemplo.

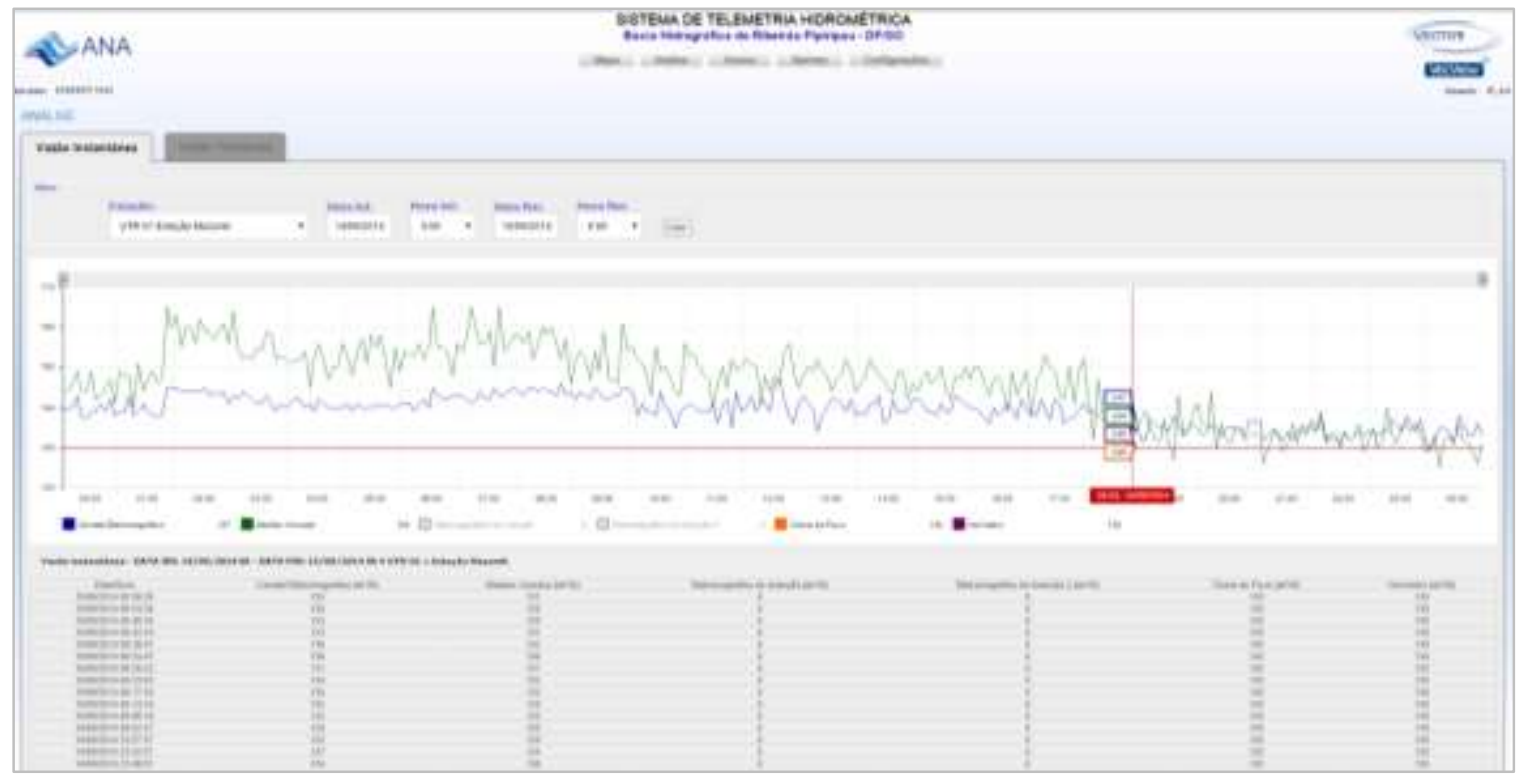

Figura C.10 - Gráfico e tabela dos dados de vazão instantânea - intervalo de 5 minutos - Estação Hidrométrica 1 - Mazurek, em 14/09/2014 (Fonte: http://ana.vector.com.br)

Já o volume totalizado é apresentado. A seguir, apresenta-se figura com os dados gráficos e em forma de tabela do volume totalizado no dia 14 de setembro de 2014, relativos à Estação 1 - Mazurek, como exemplo. 


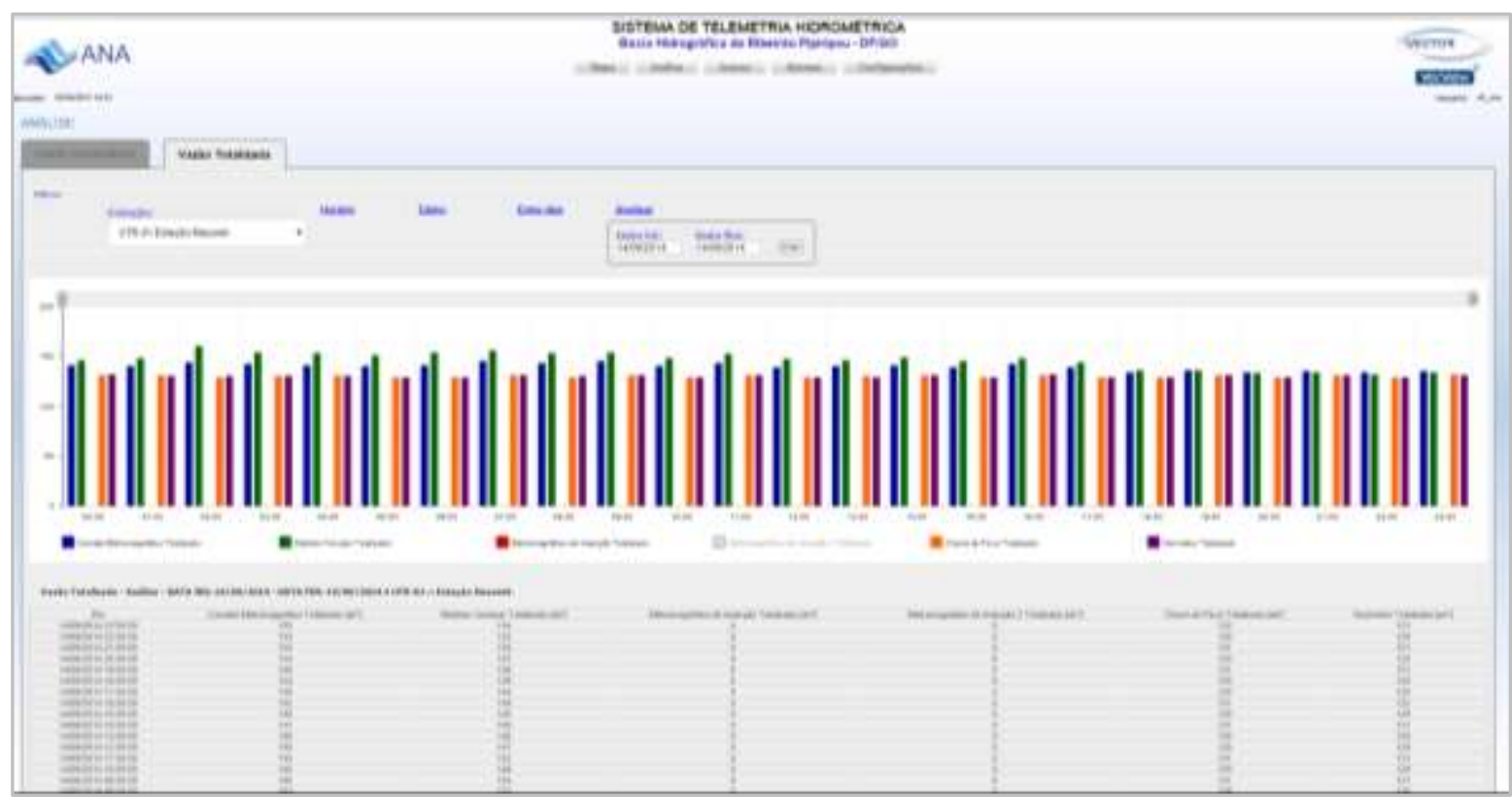

Figura C.11 - Gráfico e tabela dos dados de volume totalizado - intervalo de 60 minutos - Estação Hidrométrica 1 - Mazurek, em 14/09/2014 (Fonte: http://ana.vector.com.br)

As medições de vazão foram realizadas num período de 2 anos, entre os dias $1^{\circ}$ de novembro de 2013 a 31 de outubro de 2015, onde se verificou a resposta para cada equipamento nas 5 estações de medição, fazendo uma análise de desempenho de cada um.

Para efeito de comparação com outros medidores, foram estipulados valores fixos de vazão aos horímetros e às chaves de fluxo instalados nas Estações 1-Mazurek, 2-Areal e 3-Magela. Vale dizer que estes dispositivos são acumuladores de tempo, ou seja, não medem a vazão propriamente dita. Sendo assim, ao ligar a bomba - no caso do horímetro - e ao passar água na tubulação - para a chave de fluxo - os gráficos de vazão do site estipularam um valor fixo para cada um desses dispositivos.

Para estipular o valor fixo de vazão quando do acionamento dos horímetros e chaves de fluxo, foram realizadas medições de vazão que passa pela tubulação de cada uma dessas estações, utilizando uma técnica denominada pitometria, para se encontrar um valor de referência da vazão. Lamon (2006) define pitometria como a obtenção de velocidades de escoamento da água na tubulação, através da diferença de pressões, com a utilização do tubo de Pitot. No projeto do Pipiripau, o tubo de Pitot utilizado foi do tipo Cole (vide figuras a seguir). 


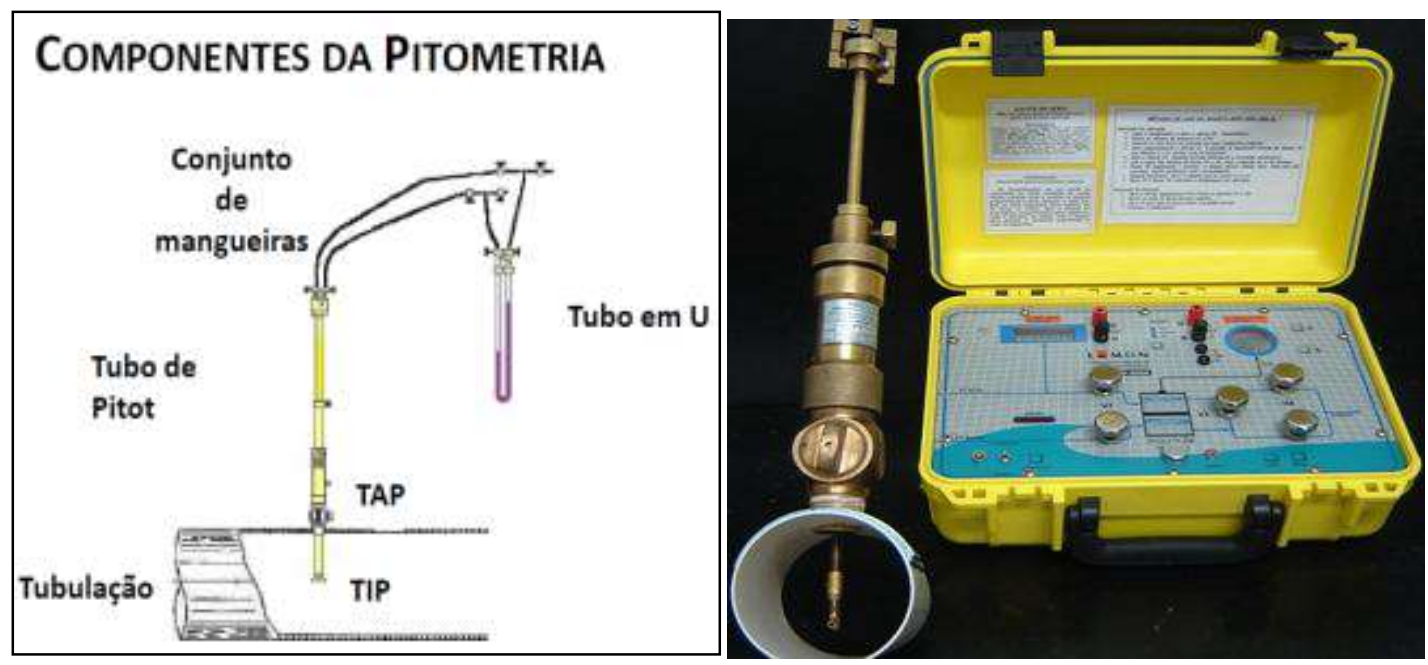

Figura C.12 - Figura demonstrativa da medição de vazão numa tubulação utilizando a pitometria (esq.) e tubo de Pitot tipo Cole (dir.). Cortesia: Vector

Lamon (2006) fez um estudo comparativo da técnica da pitometria com os métodos gravimétricos e volumétricos, ditos laboratoriais e de referência, e constatou ser este um dos métodos mais precisos para determinação da vazão instantânea em tubulações sob pressão. A técnica consiste, basicamente, em medição da velocidade em diversos pontos da seção transversal da tubulação, sendo possível traçar um perfil de velocidades e encontrar a velocidade média da tubulação (vide figura a seguir). A partir daí, tendo o diâmetro da tubulação, calcula-se a vazão no ponto.

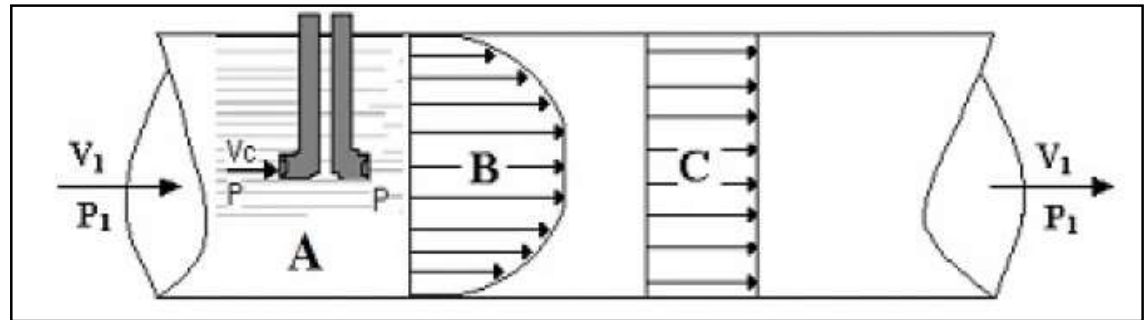

Figura C.13 - Figura demonstrativa do perfil de velocidades traçado com a pitometria (B), adotando-se uma velocidade média (C) para cálculo da vazão. Cortesia: Gustavo Carneiro

Dessa forma, foram determinados, em outubro de 2013, os valores de referência vazão pela pitometria, tendo sido estipulados aos horímetros e chaves de fluxo as seguintes vazões:

- Estação 1 - Mazurek: 130 m³/h;

- Estação 2 - Areal: $41 \mathrm{~m} 3 / \mathrm{h}$; e

- Estação 3 - Magela: 10 m³/h.

O funcionamento das estações de medição, no que tange à aquisição e transmissão dos dados de vazão, se deu num período de 2 anos, entre os dias $1^{\circ}$ de novembro de 2013 a 31 de outubro de 2015. Durante este período, foi possível verificar a resposta para cada equipamento nas 5 estações de medição, fazendo uma análise de desempenho de cada um, a ser apresentada a seguir. 
Além dos dados de vazão disponíveis, foram realizados 8 (oito) Relatórios Trimestrais nesse período de 2 (dois) anos, contendo os serviços de operação e manutenção dos equipamentos, bem como de eventuais paralisações de medição por mau funcionamento ou defeito, com as justificativas de ocorrência dos fatos. Esses dados também foram considerados para análise de desempenho dos equipamentos em campo, instalados sob efeito de intempéries, para recomendações do que se deve fazer ou evitar no que tange à instalação e manutenção.

\section{C.3} RESULTADOS E DISCUSSÕES DOS EQUIPAMENTOS INSTALADOS

Apresentam-se os resultados de desempenho quanto aos valores medidos, bem como a parte de instalação e manutenção dos equipamentos. Para facilidade de visualização, os resultados são apresentados por estação de medição e, em cada uma dessas, por equipamento instalado.

\section{C.3.1 Estação 1: Antônio Mazurek}

Em épocas de estiagem, a Fazenda Paraná - de propriedade do sr. Antônio Mazurek - capta água proveniente do Ribeirão Pipiripau, destinada à irrigação no plantio de café.

Nos dias de maior precipitação pluvial, não há necessidade de acionamento do conjunto moto-bomba (captação) para irrigação. Dessa forma, o conjunto moto-bomba permaneceu desligado entre os meses de nov/2013 a abr/2014, e de nov/2014 a mai/2015, por se tratar de período chuvoso. Entretanto, entre os dias 30/jan e 13/fev de 2014, bem como de 12 a 22/jan de 2015, houve captação de água por parte do usuário, tendo em vista a ocorrência de curtos períodos de estiagem na época de chuvas, comumente denominados de "veranico".

Dessa forma, a análise dos dados e a verificação do comportamento dos equipamentos compreendeu os períodos entre: 29/abr a 24/out de 2014 (6 meses) e 25/mai a 28/out de 2015 (5 meses), período seco onde houve regularidade de captação.

Relativo ao período seco de 2014, apresenta-se gráfico comparativo das vazões instantâneas registradas pelos equipamentos, em $\mathrm{m}^{3} / \mathrm{h}$, ao longo do tempo, tomando como exemplo o período entre os dias 21 e 27 de maio de 2014: 


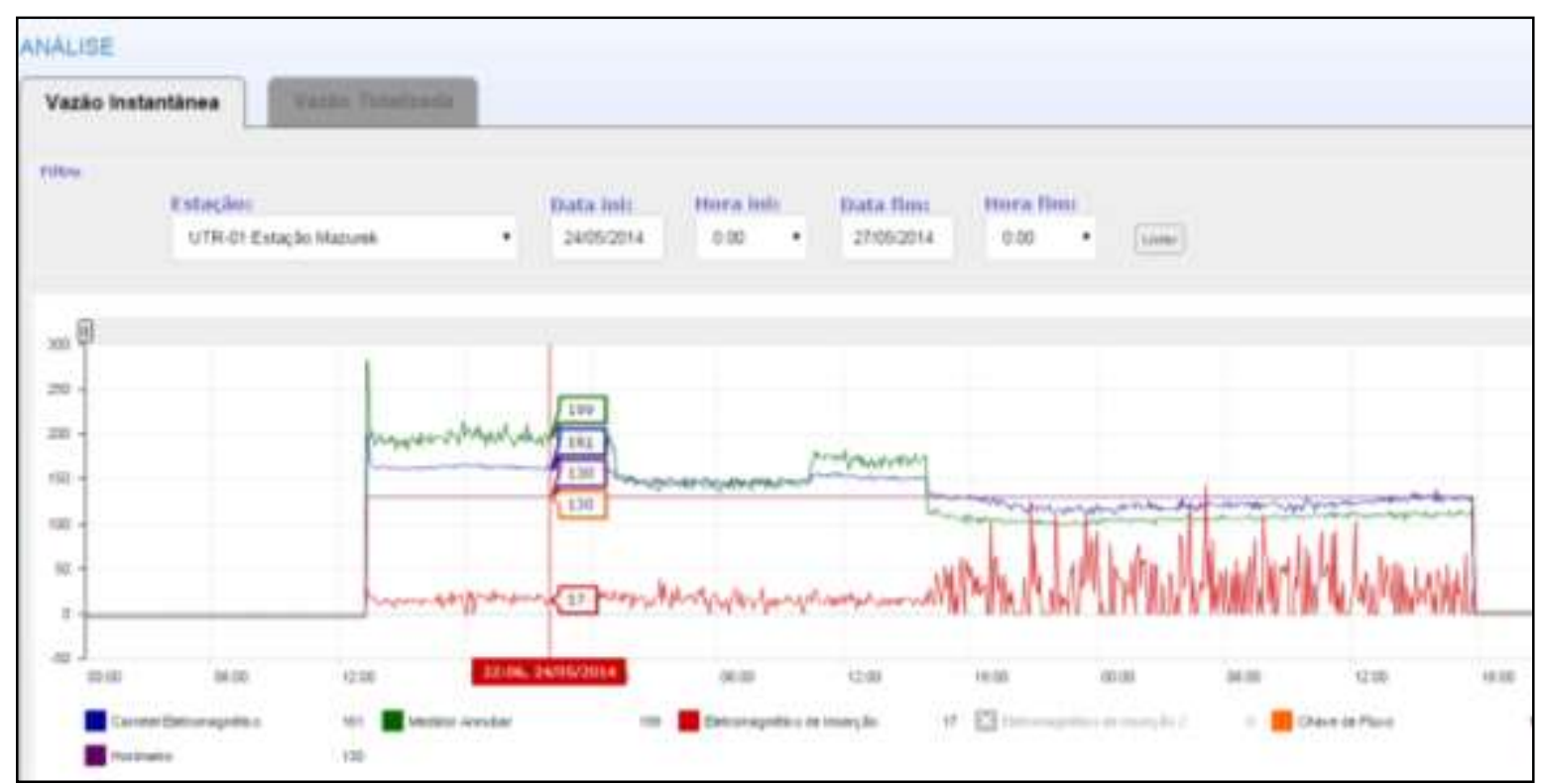

Figura C.14 - Gráfico dos dados de vazão instantânea - Estação Hidrométrica 1 - Mazurek, entre os dias 21 e 27/05/2014 (Fonte: http://ana.vector.com.br)

Como informado anteriormente, o horímetro (destaque em roxo) e a chave de fluxo (destaque em laranja) são acumuladores de tempo, isto é, não medem a vazão propriamente dita. Dessa forma, quando não estão em funcionamento, as medições aparecem no gráfico comparativo como 0 e, quando estão registrando corrente (horímetro) e passagem de água pela tubulação (chave de fluxo), aparecem no gráfico como $130 \mathrm{~m} 3 / \mathrm{h}$, valor de referência medido pela pitometria.

No período seco de 2014, foram registradas 17.583 medições. O eletromagnético de carretel (linha azul) foi o equipamento que apresentou vazão média mais próximo do valor de referência, com 130,8 $\mathrm{m}^{3} / \mathrm{h}$, e menor desvio padrão, com 17,5 m³/h. Já o tubo de Pitot (ou Annubar), representado pela linha verde, mediu valores amplitude maior, tal qual representado no gráfico, com média também próxima do valor de referência, de $133,1 \mathrm{~m}^{3} / \mathrm{h}$ e desvio de $28,6 \mathrm{~m}^{3} / \mathrm{h}$. Por fim, o eletromagnético de inserção 1 (linha vermelha) mediu valores bem inferiores ao valor de referência, com 22,0 de média e desvio de $22,4 \mathrm{~m}^{3} / \mathrm{h}$. Tendo em vista os registros inconsistentes do medidor de inserção $1 \mathrm{em} 2014$, foi adquirido um medidor de inserção 2, que funcionou somente no período seco de 2015.

Em 2015, o sistema de captação do empreendimento foi ligado bem menos que em 2014: foram 6.842 registros de medições, ou seja, o conjunto motor-bomba funcionou em $40 \%$ do tempo, se comparado a 2014. O principal fator para essa diminuição foi a contratação de profissional na área de irrigação que instalou tensiômetros para verificação da quantidade ótima de água para o plantio de café, tendo diminuído o número de horas diárias captação. Outro motivo foi o período seco de 2015, que foi de 5 meses, sendo o de 2014 com 6 meses sem chuvas. 
Como último aspecto, mais importante para o objeto do presente trabalho, a fazenda Mazurek realizou reparos no sistema de captação para o ano de 2015, com substituição de tubulações com vazamentos, retificação do conjunto motor-bomba e alteração da locação da base do pivô. Todas essas alternativas geraram uma alteração no valor médio das vazões. Segue gráfico representativo do $2^{\circ}$ período seco, no ano de 2015, tomando como exemplo o intervalo entre os dias 21 a 23 de outubro de 2015:

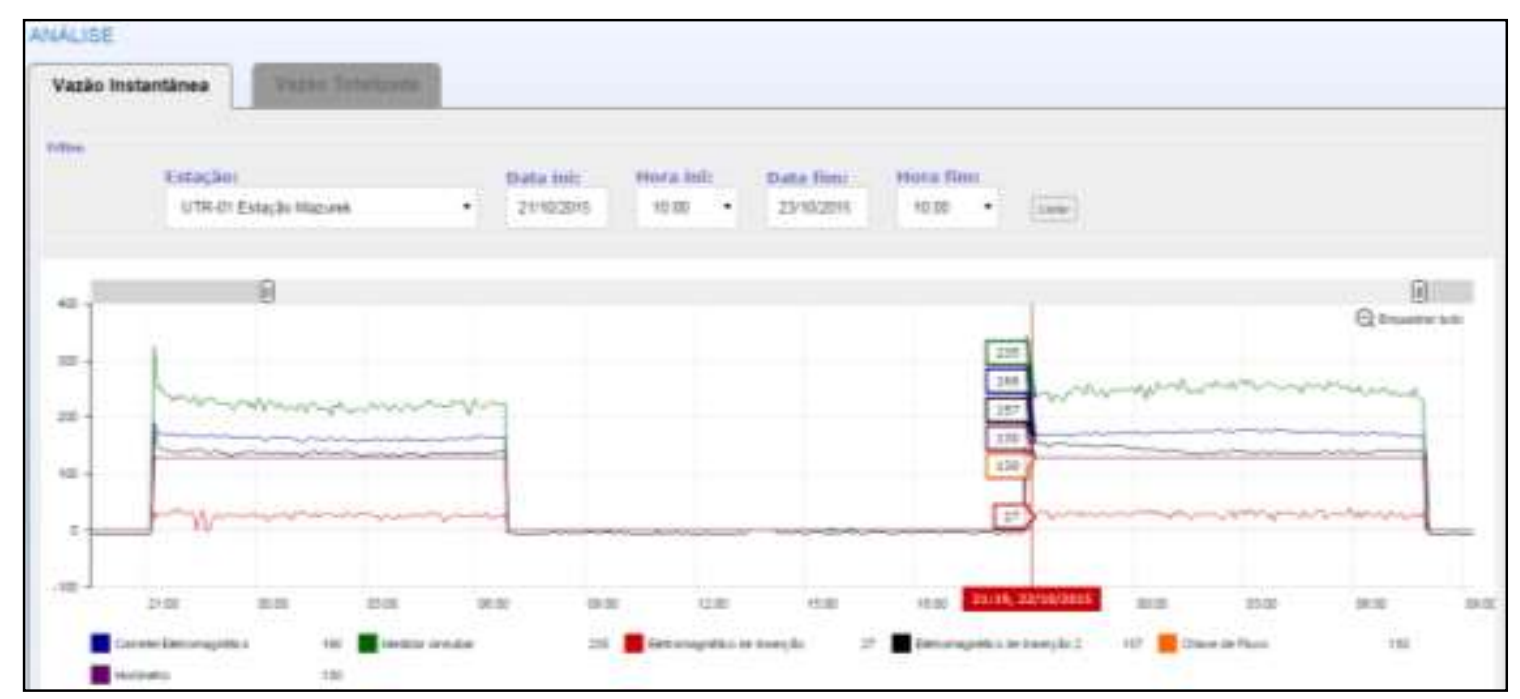

Figura C.15 - Gráfico dos dados de vazão instantânea - Estação Hidrométrica 1 - Mazurek, entre os dias 21 e 23/10/2015 (Fonte: http://ana.vector.com.br)

O eletromagnético de carretel (linha azul) apresentou vazão média de $159,2 \mathrm{~m}^{3} / \mathrm{h}$, e desvio de 7,9 $\mathrm{m}^{3} / \mathrm{h}$. O eletromagnético de inserção 2 (linha preta) foi o equipamento que mediu mais próximo do carretel, com 160,9 m³/h de média e 9,3 m³/h de desvio. Já o Annubar, para vazões maiores, apresentou valores médios de 202,9 m³/h e desvio de 21,0 $\mathrm{m}^{3} / \mathrm{h}$. Ou seja, o Annubar (linha verde) registrou, em média, vazões $27 \%$ superiores às medições do carretel. Por fim, o eletromagnético de inserção 1 (linha vermelha) mediu valores bem inferiores ao valor de referência, com 27,6 de média e desvio de $4,7 \mathrm{~m}^{3} / \mathrm{h}$.

Uma vez identificada a alteração nas vazões do empreendimento, e não havendo previsão contratual de realização de nova pitometria para determinar um valor de referência para 2015, optou-se por realizar medição de vazão com outro equipamento de medição: ultrassônico de vazão por tempo de trânsito, portátil, medição esta realizada em 2 de julho de 2015. Este equipamento é utilizado pela fiscalização da ANA em campanhas de fiscalização para averiguação do uso, e tem como erro de medição teórico, em manuais, de 5\%. Foram registradas 200 medições, em 1 hora de funcionamento, com média de $157,1 \mathrm{~m}^{3} / \mathrm{h}$ (vide figura abaixo). 


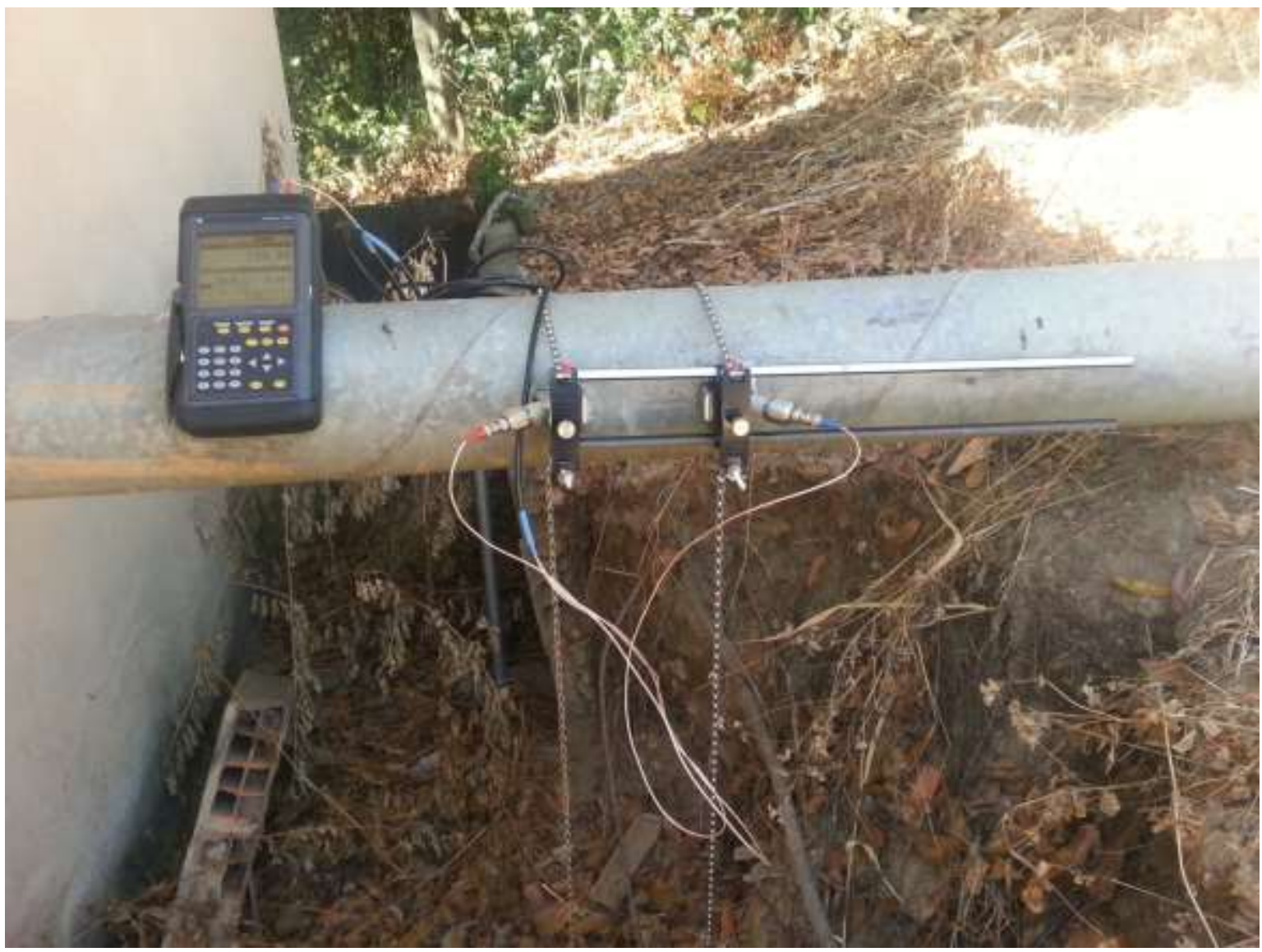

Figura C.16 - Estação 1 - Mazurek: Medição de vazão utilizando ultrassônico por tempo de trânsito, em 2 de julho de 2015 - vazão média: $157,1 \mathrm{~m}^{3} / \mathrm{h}$

Em termos de desempenho, operação e manutenção, temos a seguinte análise para cada equipamento:

Eletromagnético de carretel: pelos registros em 2014, comparados com o valor de referência medido, confirmou-se o que foi visto na revisão teórica do presente trabalho: este medidor possui boa precisão, ou seja, seus registros de vazão são próximos do real. Os valores de 2015 não podem ser comparados à medição feita pela pitometria de 2014. Em compensação, para se ter uma ideia de grandeza de valores, pela medição realizada com o ultrassônico em 2 de julho de 2015, com vazão média de 157,1 $\mathrm{m}^{3} / \mathrm{h}$, verifica-se que os valores médios do carretel em 2015 , de $159,2 \mathrm{~m} 3 / \mathrm{h}$, estão bem próximos, o que corrobora o aumento dos valores médios de vazão registrados pelo eletromagnético em 2015.

No que tange à parte de operação e manutenção, houve um vazamento da tubulação em agosto/2014, próximo ao local onde o medidor de carretel estava instalado, que provocou falhas no display do equipamento. Após conserto, a mesma foi reinstalada no painel elétrico, e não houve mais necessidade de manutenção (vide figura abaixo). 

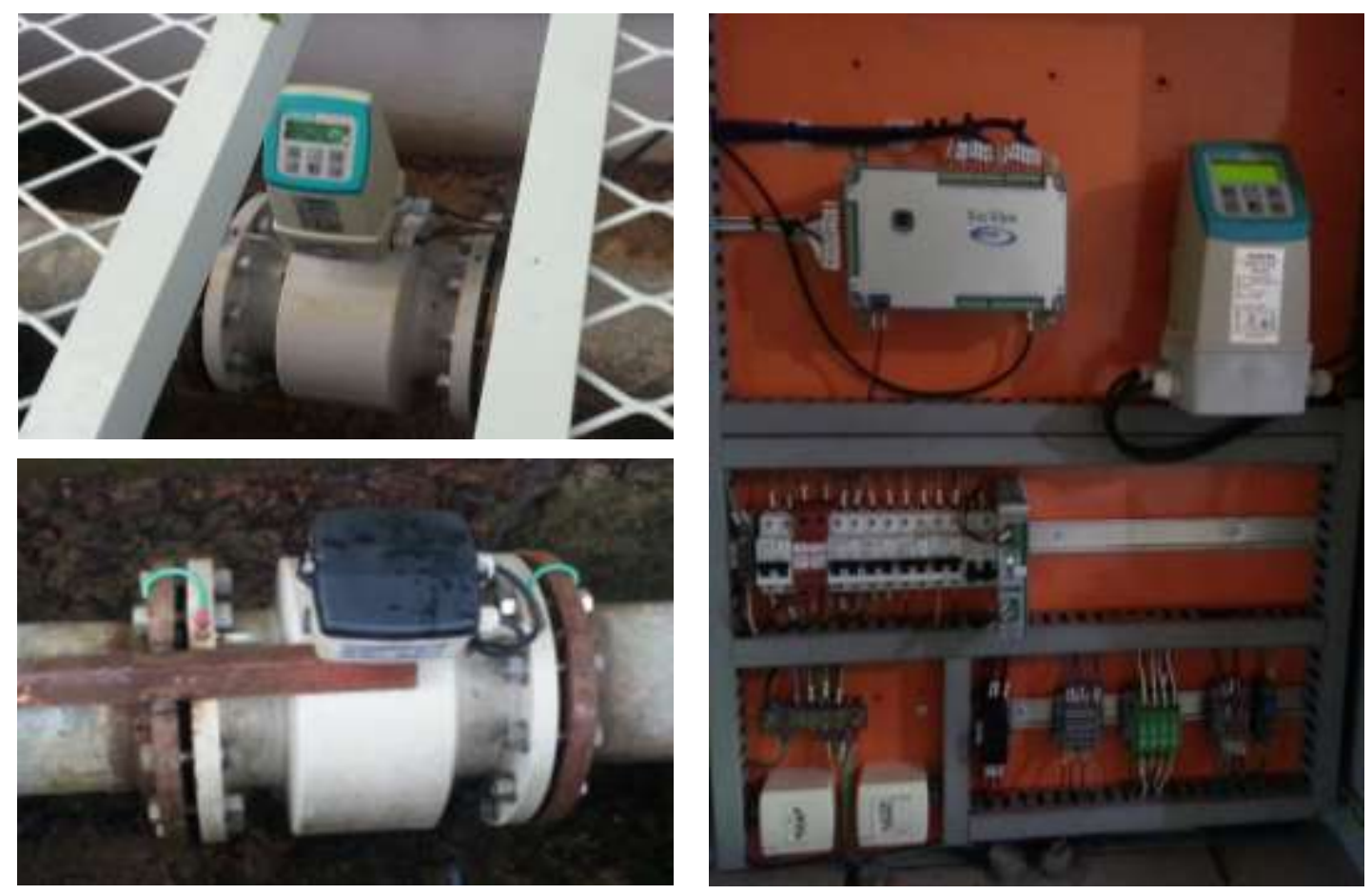

Figura C.17 - Estação 1 - Mazurek: Display do eletromagnético de carretel instalado na tubulação (acima, à esq.), retirado em ago/2014 para conserto (abaixo, à esq.) e reinstalado no painel (à direita)

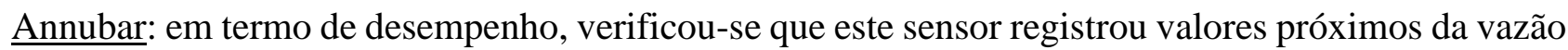
de referência em 2014; porém, em 2015, os valores medidos foram, em média superiores em 27\%, se comparados com o eletromagnético de carretel, com o eletromagnético de inserção 2 e com as medições realizadas com o ultrassônico no dia 2 de julho de 2015. A razão para esta diferença a mais provavelmente está ligada às configurações do aparelho. Isso porque o equipamento solicita, como dados de entrada, vazões de mínima, média e máxima. O equipamento foi calibrado em 2014 e não foi alterado em 2015. Uma vez que os valores reais foram majorados em 2015 pelas mudanças no empreendimento anteriormente relacionadas, pode ter causado distorções nos valores medidos pelo equipamento em 2015.

Outro fato foi constatado no desempenho do Annubar: com a bomba desligada, mediu valores diferentes de zero, conforme pode ser observado na figura a seguir, com destaque circulado de preto: 




Figura C.18 - Gráfico dos dados de vazão instantânea - Estação Hidrométrica 1 - Mazurek, entre os dias $1^{\circ}$ e 10/06/2014 (Fonte: http://ana.vector.com.br)

O sensor Annubar mede a vazão em função da pressão diferencial, sendo sensível às mínimas variações de pressão no interior da tubulação de recalque. A válvula de retenção existente na linha de recalque do Mazurek estava danificada, e não retinha água após o desligamento da bomba. Sendo assim, ao se desligar a bomba, toda a tubulação se esvazia, visto que a captação se encontra em nível inferior ao do pivô de irrigação. Com a tubulação vazia, sem água, a diferença topográfica e térmica entre o ponto onde o sensor Annubar está instalado e o pivô de irrigação provoca um fluxo de ar ascendente (convecção térmica) no interior da tubulação, e este fluxo é 'captado' pelas câmaras do sensor Annubar, fazendo com que o equipamento faça medidas de pressão diferencial, sem ter água passando pelo tubo.

No que tange à operação, constatou-se vazamento na conexão do sensor Annubar à tubulação de recalque, quando a moto-bomba estava em funcionamento, tendo sido verificado que desgaste na conexão por ressecamento. Em relação à manutenção, verificou-se, na manutenção preventiva realizada pela equipe técnica, necessidade de retira do sensor primário de vazão (haste), para limpeza dos furos, num período de dois em dois meses. Conclusão: para funcionamento deste equipamento, verificou-se necessidade de manutenção periódica.

Eletromagnético de inserção 1: apresentou inconsistências nas medições, tanto em 2014, quanto em 2015. Segundo parecer técnico do fabricante, as medições incorretas foram causadas por acúmulo de sólidos no sensor do equipamento, por excesso de vibração na tubulação e/ou pela presença de ar. Aliado a isto, constatou-se que a tensão trifásica fornecida nesta estação estava em 347Vac, sendo que esta tensão baixa provoque uma tensão de alimentação do medidor de 201Vac. No manual do equipamento, consta que a faixa de alimentação tolerada pelo medidor seja de $220 \mathrm{Vac}+/-5 \%$ 
(209Vac a 231Vac), ou seja, o valor da tensão real estava abaixo do limiar mínimo requerido pelo fabricante. Além disso, em termos de operação e manutenção, dois fatos merecem destaque: em primeiro, houve queima do display do equipamento pela exposição às intempéries, tendo sido trocado e protegido o novo com chapa de alumínio; em segundo, verificou-se a necessidade de limpeza periódica do equipamento, mensal, devido ao acúmulo de sedimentos no sensor.
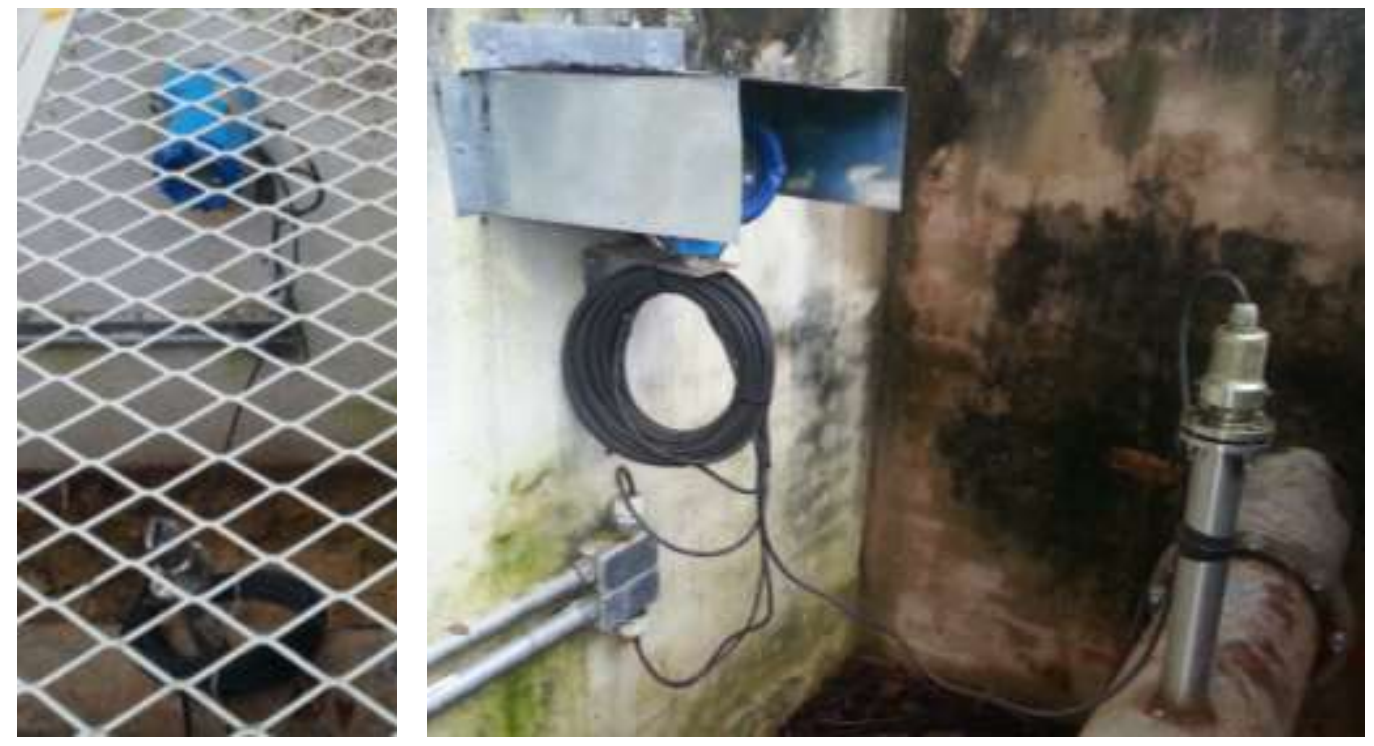

Figura C.19 - Estação 1 - Mazurek: Display do eletromagnético sem proteção (esq.) e com chapa de aluminío protegendo contra intempéries (dir.)

Eletromagnético de inserção 2: pelas inconsistências do eletromagnético de inserção 1, e por haver espaço na tubulação e no sistema de recepção e transmissão de dados da Estação 1 para instalação de mais um medidor, foi possível colocar um eletromagnético de inserção de outro fabricante, no final de 2014, sendo possível a análise dos dados no período de 2015. No que diz respeito ao desempenho, apresentou valores similares ao eletromagnético de carretel e ao ultrassônico por tempo de trânsito, diferente da resposta do outro medidor de inserção. Em termos de operação, funcionou em todo o período de 2015, sem apresentar problemas, na parte de manutenção, verificou-se também a necessidade de limpeza periódica do equipamento, mensal, devido ao acúmulo de sedimentos no sensor.

Horímetro: em termos de desempenho, não há o que ser analisado, uma vez que o dispositivo não mede valores, somente registra se o conjunto motor-bomba está ligado ou desligado. Cabe somente frisar que, havendo alterações na vazão do sistema, conforme houve na Estação 1 - Mazurek do ano 2014 para o ano 2015, este equipamento não irá verificar a mudança. Na parte da operação, funcionou normalmente: quando houve acionamento da bomba, fez a contagem do tempo; quando estava desligada, a contagem não foi computada. Não foi necessária manutenção para o horímetro. 
Chave de fluxo: tal qual o horímetro, em termos de desempenho, não há o que ser analisado, uma vez que o dispositivo não mede valores, somente registra se o conjunto motor-bomba está ligado ou desligado. Na parte da operação, funcionou normalmente: quando houve acionamento da bomba, fez a contagem do tempo; quando estava desligada, a contagem não foi computada. Não foi necessária manutenção para a chave de fluxo.

\section{C.3.2 Estação 2: Areal Campos Agrícola LTDA}

A empresa Areal Campos Agrícola capta água do ribeirão Pipiripau para lavagem e beneficiamento de areia e para consumo humano dos funcionários locais. O sistema de captação é composto por um conjunto moto-bomba que funciona durante todo o período comercial, ou seja, de segunda a sextafeira das $8 \mathrm{~h}$ às $18 \mathrm{~h}$. Aos sábados, o acionamento do conjunto moto-bomba é esporádico.

Dessa forma, a análise dos dados e a verificação do comportamento dos equipamentos foi compreendeu os dois anos de funcionamento, isto é, entre nov/13 e out/2015.

Apresenta-se gráfico comparativo das vazões instantâneas registradas pelos equipamentos, $\mathrm{em} \mathrm{m}^{3} / \mathrm{h}$, ao longo do tempo, tomando como exemplo o período entre os dias 21 e 27 de maio de 2014:

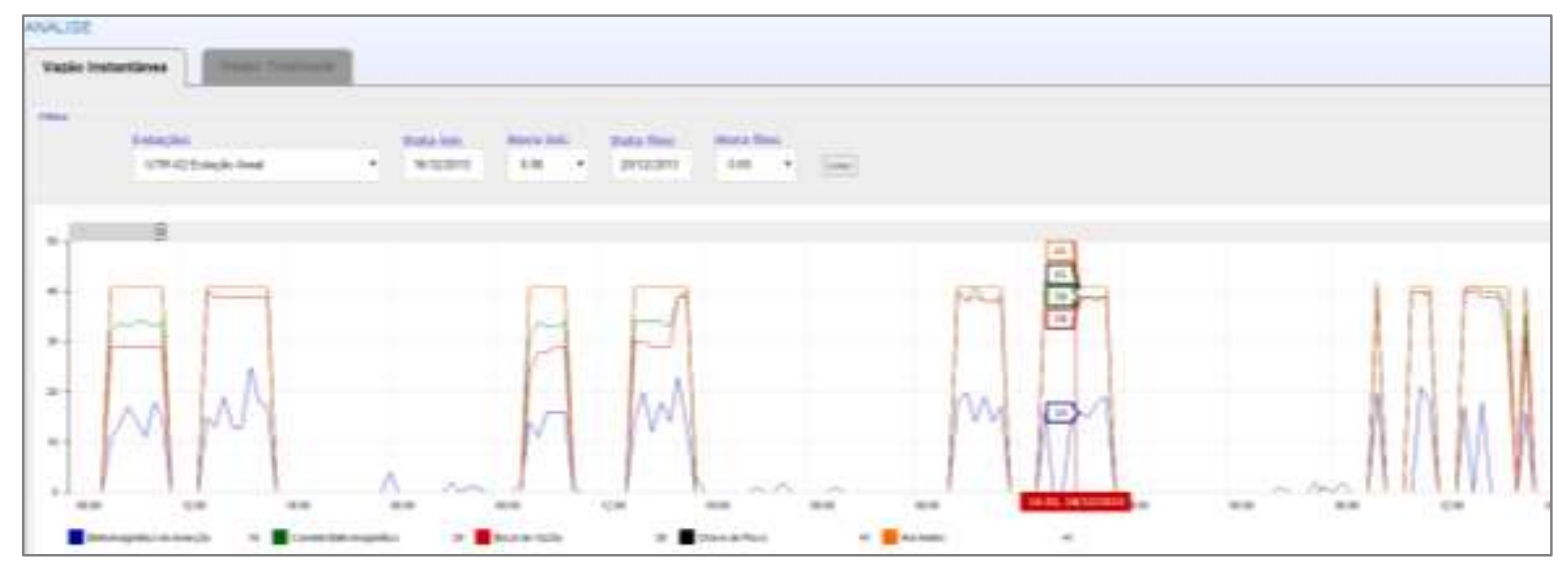

Figura C.20 - Gráfico dos dados de vazão instantânea - Estação Hidrométrica 2 - Areal, entre os dias 16 e 20/12/2013 (Fonte: http://ana.vector.com.br)

Como informado anteriormente, o horímetro (destaque em laranja) e a chave de fluxo (destaque em preto) são acumuladores de tempo, isto é, não medem a vazão propriamente dita. Dessa forma, quando não estão em funcionamento, as medições aparecem no gráfico comparativo como 0 e, quando estão registrando corrente (horímetro) e passagem de água pela tubulação (chave de fluxo), aparecem no gráfico como $41 \mathrm{~m}^{3} / \mathrm{h}$, valor de referência medido pela pitometria.

Em todo o período de funcionamento foram registradas 19.908 medições. O eletromagnético de carretel (linha azul) foi o equipamento que apresentou vazão média mais próximo do valor de referência, 
com $42,1 \mathrm{~m}^{3} / \mathrm{h}$, e menor desvio padrão, com 3,7 m³/h. Já o bocal de vazão, representado pela linha vermelha, registrou valores com média um pouco inferior ao valor de referência, de $36,5 \mathrm{~m}^{3} / \mathrm{h}$ e desvio de $6,3 \mathrm{~m}^{3} / \mathrm{h}$, ou seja, apresentou valores com amplitude maior. Por fim, percebe-se nitidamente pelo gráfico que o eletromagnético de inserção (linha azul) mediu valores bem inferiores ao valor de referência, com 16,2 de média e desvio de $5,6 \mathrm{~m}^{3} / \mathrm{h}$.

Tratando de desempenho, operação e manutenção dos equipamentos, tem-se:

Eletromagnético de carretel: além do medidor carretel instalado na Estação 1, confirmou-se também nesta Estação o previsto na revisão bibliográfica: o referido equipamento possui boa precisão, ou seja, seus registros de vazão são próximos do real. No que tange à parte de operação e manutenção, houve um problema de queima do display exposição às intempéries, tendo sido trocado e protegido o novo com chapa de alumínio, procedimento também adotado para os displays do bocal e do eletromagnético de inserção (vide figura a seguir). Vale comentar que o problema do display não acarretou problemas na medição, pois o equipamento continuou registrando e enviando as vazões medidas por celular; o único comprometimento foi com a leitura da vazão in loco.

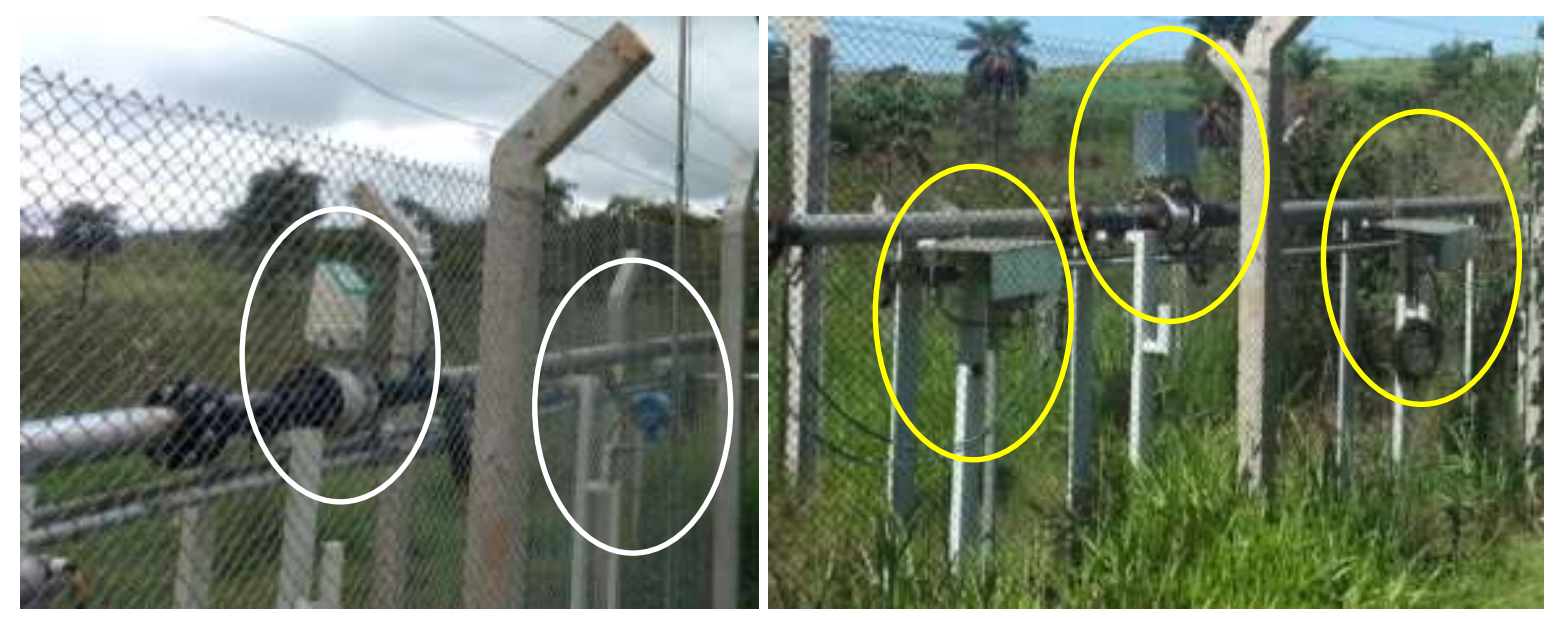

Figura C.21 - Estação 2 - Areal: equipamentos sem proteção (esq. - contorno em branco) e com proteção de chapa de alumínio (dir. - contorno em amarelo)

Bocal de vazão: em termo de desempenho, verificou-se que este sensor registrou valores próximos da vazão de referência. Entretanto, no que tange à operação, o medidor apresentou problemas ao longo dos dois anos, e o equipamento foi retirado da linha para reparos/consertos por três vezes, e ficou sem registros por quase a metade do tempo de funcionamento. Verificaram-se problemas de desconfiguração (sem o técnico conseguir configurar novamente) e de desligamento do equipamento sem constatação de anomalias externas (curto, saída analógica danificada, fusível rompido, proteção de surto, ou umidade) que pudesse causar o não funcionamento do equipamento. No que tange à operação, vale aqui comentar que, aparentemente, a água bruta captada pelo areal apresentava maior 
quantidade de sedimentos, havendo necessidade de retirada das mangueiras do diferencial de pressão para limpeza.

Eletromagnético de inserção 1: apresentou inconsistências nas medições. Tal qual o Mazurek, também na Estação Areal a tensão real estava abaixo do limiar mínimo requerido pelo fabricante: verificou-se tensão $193 \mathrm{Vac}$, sendo que a tensão deveria estar no intervalo entre 209Vac a 231Vac. Além disso, no que concerne à manutenção, verificou-se um excesso de acúmulo de impurezas no sensor, com necessidade de limpeza periódica do equipamento, conforme figura a seguir.
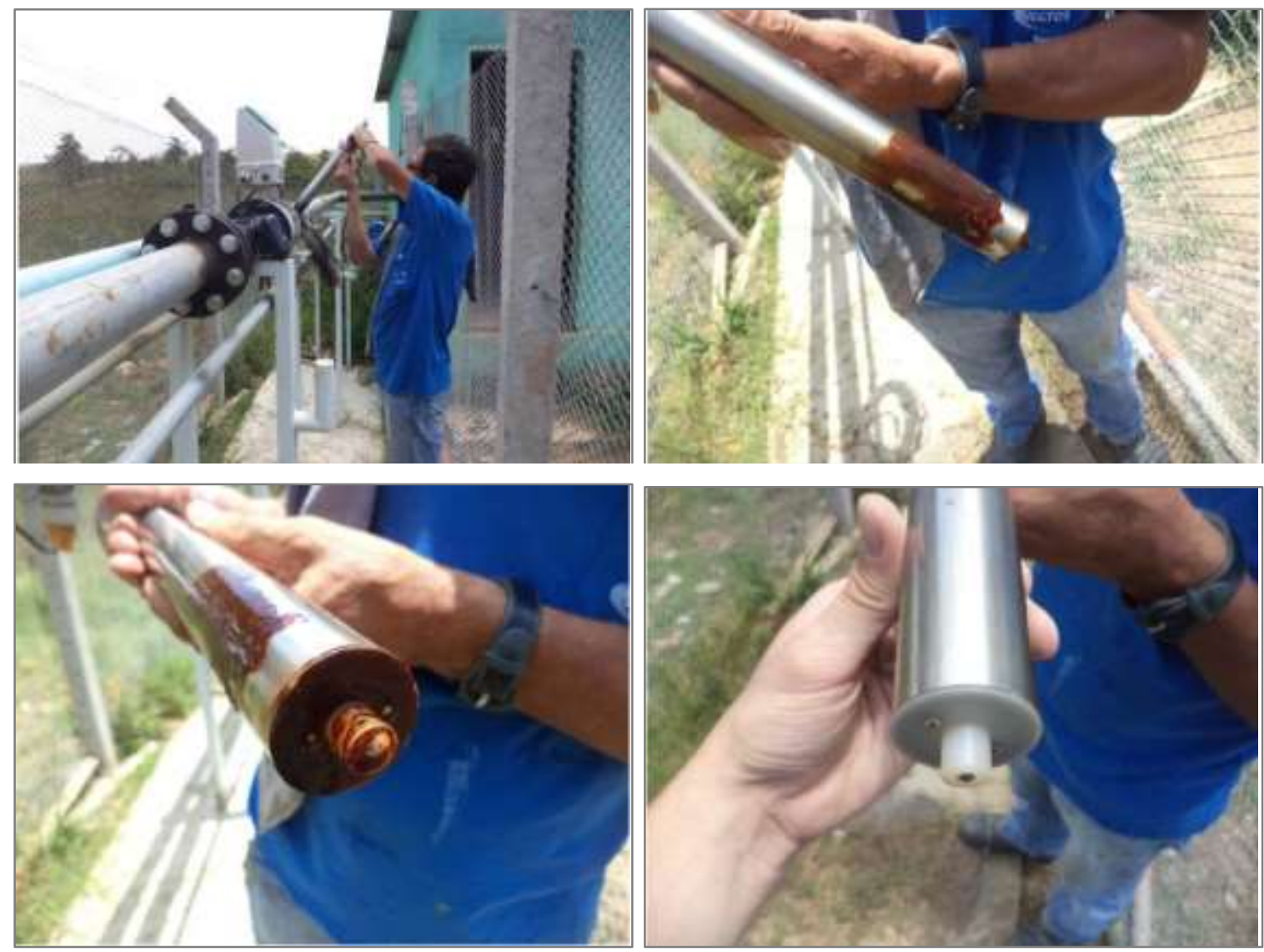

Figura C.22 - Estação 2 - Areal: retirada e limpeza do medidor de inserção

Horímetro: em termos de desempenho, não há o que ser analisado, uma vez que o dispositivo não mede valores, somente registra se o conjunto motor-bomba está ligado ou desligado. Na parte da operação, funcionou normalmente: quando houve acionamento da bomba, fez a contagem do tempo; quando estava desligada, a contagem não foi computada. Não foi necessária manutenção para o horímetro.

Chave de fluxo: tal qual o horímetro, em termos de desempenho, não há o que ser analisado, uma vez que o dispositivo não mede valores, somente registra se o conjunto motor-bomba está ligado ou desligado. Entretanto, na parte da operação, a chave de fluxo travou por 5 vezes, tendo em vista acúmulo 
de sedimentos na palheta, provocando que a mesma ficasse levantada, mesmo não havendo passagem de água. Todas as vezes que ocorreu a medição contínua da chave de fluxo, conforme demonstra o gráfico a seguir, o técnico de manutenção retirou o dispositivo da tubulação, efetuou a limpeza e reinstalou, voltando a funcionar novamente. Tendo em vista o ocorrido, realizou-se limpeza periódica na chave.

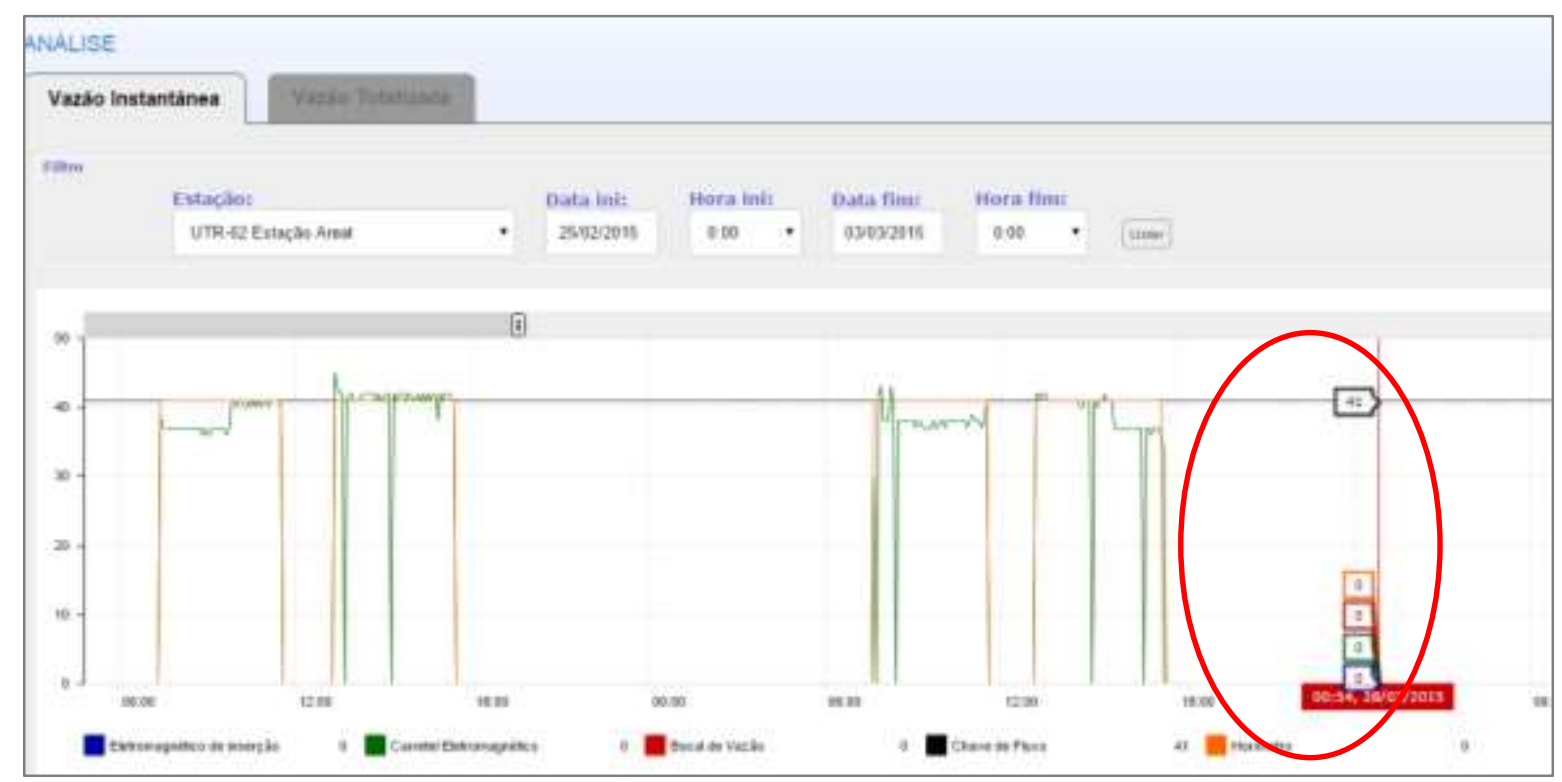

Figura C.23 - Estação 2 - Areal: Gráfico da vazão instantânea x tempo, entre os dias 25/02 a 03/03/2015, com detalhe da chave de fluxo estar ligada de forma contínua (linha em preto). Fonte: http://ana.vector.com.br

\section{C.3.3 Estação 3: Geraldo Magela}

Na propriedade do Sr. Geraldo Magela, realiza-se captação de água de um afluente do ribeirão Pipiripau para irrigação de hortaliças em cultivo protegido. O sistema de captação é composto por um conjunto moto-bomba além de uma bomba injetora de fertilizante e um filtro de discos.

Em tempos de chuva, diferentemente da Estação 1 - Mazurek, que quase não acionou o bombeamento, na Estação 3 houve somente uma diminuição do tempo de uso, mas não houve uma paralisação. Nos períodos chuvosos de nov/2013 a abr/2014, e de nov/2014 a mai/2015, a bomba foi acionada em $40 \%$ dos dias, e 3 horas/dia, em média. Já no período seco, compreendido entre os meses de mai/2014 a out/2014, e de jun/2015 a out/2015, houve captação em 70\% dos dias com, aproximadamente, 4,5 horas/dia de uso.

Apresenta-se gráfico comparativo das vazões instantâneas registradas pelos equipamentos, em $\mathrm{m}^{3} / \mathrm{h}$, ao longo do tempo, tomando como exemplo o período entre os dias 13 e 18 de outubro de 2015 : 


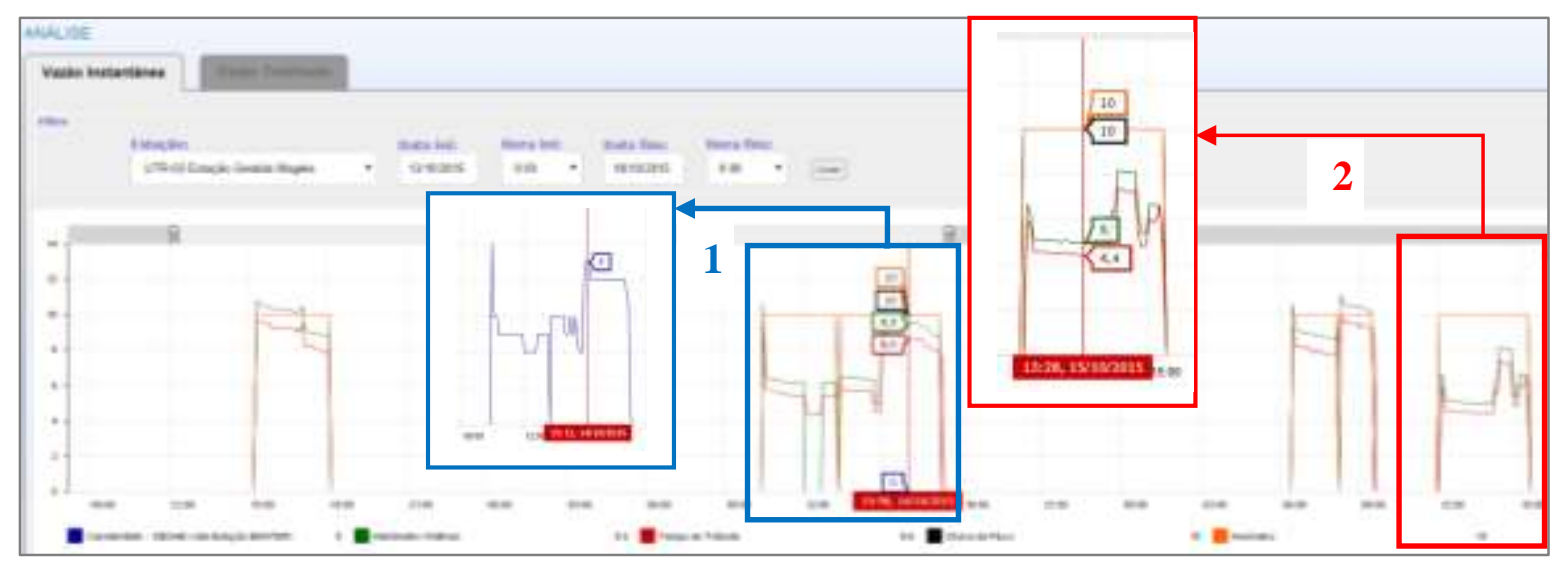

Figura C.24 - Gráfico dos dados de vazão instantânea - Estação Hidrométrica 3 - Magela, entre os dias 13 e 18/10/2015 (Fonte: http://ana.vector.com.br)

Como informado anteriormente, o horímetro (destaque em laranja) e a chave de fluxo (destaque em preto) são acumuladores de tempo, isto é, não medem a vazão propriamente dita. Dessa forma, quando não estão em funcionamento, as medições aparecem no gráfico comparativo como 0 e, quando estão registrando corrente (horímetro) e passagem de água pela tubulação (chave de fluxo), aparecem no gráfico como $10 \mathrm{~m}^{3} / \mathrm{h}$, valor de referência medido pela pitometria.

Em todo o período de funcionamento foram registradas 6.405 medições. O hidrômetro tipo Woltmann (linha verde) apresentou média de $9,84 \mathrm{~m}^{3} / \mathrm{h}$ e desvio de $1,45 \mathrm{~m}^{3} / \mathrm{h}$. Já o ultrassônico por tempo de trânsito (linha vermelha) registrou valores médios de $9,29 \mathrm{~m}^{3} / \mathrm{h}$ e desvio de $1,50 \mathrm{~m}^{3} / \mathrm{h}$, valores bem próximos do eletromagnético de carretel, este com $9,24 \mathrm{~m}^{3} / \mathrm{h}$ de média e $1,42 \mathrm{~m}^{3} / \mathrm{h}$ de desvio.

A título de explicação, em relação ao contorno $\mathrm{n}^{\circ} 1$ (em azul) e ao gráfico azul representado acima, corresponde as medições de vazão instantânea do eletromagnético de carretel, que na verdade aparecem na Estação 6 - Emater, e foram resgatadas dessa outra estação para comparação de dados. Isso porque o projeto do Pipiripau previu testes de comparação de tipos de transmissão, e os dados de vazão do carretel instalado no Magela foram transmitidos via rádio para a Estação 6 - Emater, sendo possível acessá-los somente nesta outra estação. Mas em nada prejudicaram no trabalho de comparação entre os valores medidos.

Já o contorno em 2, em vermelho, representa uma peculiaridade observada na medição de vazão instantânea: apesar da vazão de referência ser de $10 \mathrm{~m} 3 / \mathrm{h}$, foram medidos valores instantâneos bem inferiores aos de referência, da ordem de 4 a $5 \mathrm{~m}^{3} / \mathrm{h}$.

Verificou-se que o sistema de irrigação instalado pelo Sr. Geraldo Magela possui uma válvula de pressão na saída da tubulação. Esta válvula controla a quantidade de água a ser enviada para as hor- 
taliças, de forma que, quando parcialmente fechada, diminui a vazão na tubulação (vide figura a seguir). Isso se deve ao fato do operador da bomba fechar parcialmente a válvula quando precisava molhar somente as estufas próximas ao ponto de captação, diminuindo a vazão do sistema.

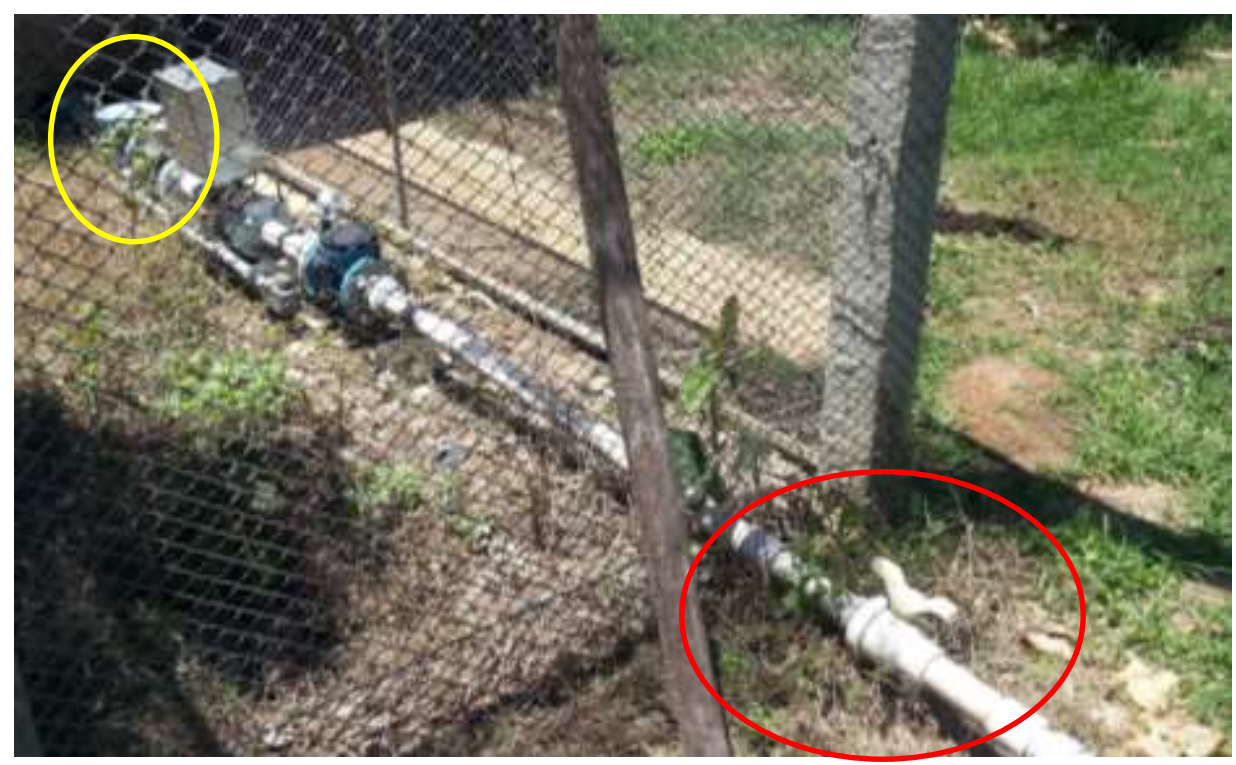

Figura C.25 - Estação 3 - Magela: detalhe da válvula de pressão instalada no final, para diminuição da vazão, para envio de água às estufas mais próximas

Tratando de desempenho, operação e manutenção dos equipamentos, tem-se:

Eletromagnético de carretel: na Estação 3 - Magela, verificou-se mais uma vez que o medidor carretel possui confiabilidade nas medições e, tal qual os equipamentos instalados nas Estações 1 e 2 , a resposta deste eletromagnético da Estação 3 foi positiva, com seus registros de vazão são próximos do real. No que tange à parte de operação e manutenção, apesar de não ter havido problema de queima do display, como houve na Estação 2, optou-se também por protegê-lo com chapa de alumínio, procedimento este recomendado pelo fabricante no manual (vide detalhe em amarelo na figura anterior).

Ultrassônico por tempo de trânsito: este ultrassônico instalado foi do tipo intrusivo, ou seja, já vem preparado de fábrica com as distâncias entre dois os transdutores: o emissor e o receptor do sinal ultrassônico. Apesar de ter sido instalado próximo aos outros dispositivos, foi respeitada a distância mínima de trecho reto requerida pelo fabricante. Constatou-se desempenho similar ao carretel, em termos de medição. Quanto à operação e manutenção: não houve necessidade alguma de intervenção do técnico ao longo dos dois anos.

Hidrômetro Woltmann: no que tange à medição, os valores de vazão ficaram 6,5\% superiores ao do carretel e ao do ultrassônico, quase que sistematicamente em todas as medições. Pelos resultados, apesar da diferença não ter sido muito representativa, verifica-se uma necessidade de correção dos 
valores. Em relação à operação, funcionou normalmente, sem necessidade de conserto. Já quanto à manutenção, pelas inspeções periódicas na estação, verificou-se a necessidade de limpeza do filtro de disco, instalado antes do hidrômetro.

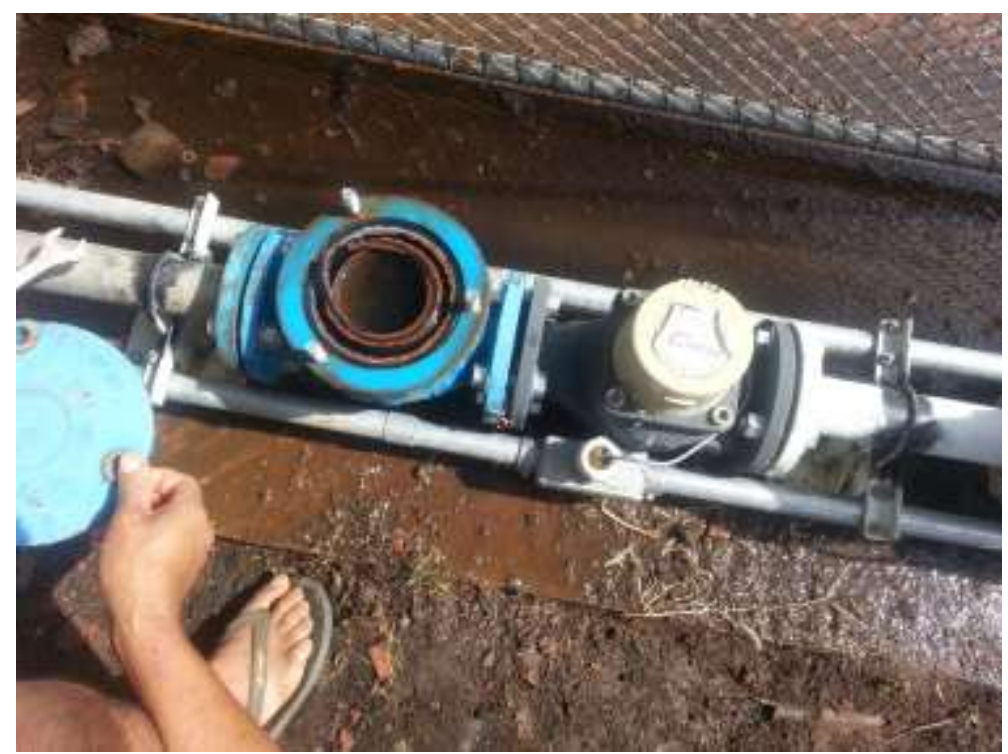

Figura C.26 - Estação 3 - Magela: limpeza de filtro de disco (esq.) instalado antes do hidrômetro (dir.)

Horímetro: em termos de desempenho, não há o que ser analisado, uma vez que o dispositivo não mede valores, somente registra se o conjunto motor-bomba está ligado ou desligado. Entretanto, uma vez que o horímetro ficou programado com o valor de referência, de $10 \mathrm{~m}^{3} / \mathrm{h}$, que é um valor constante e inserido no sistema, a vazão instantânea e o volume totalizado desse dispositivo foi superior aos medidores de velocidade: hidrômetro, ultrassônico por tempo de trânsito e eletromagnético de carretel. Isso porque há uma válvula de retenção instalada a jusante dos equipamentos, utilizada pelo usuário para diminuir a pressão do sistema quando é necessário enviar água às regiões mais próximas, conforme mencionado anteriormente. Na parte da operação, funcionou normalmente: quando houve acionamento da bomba, fez a contagem do tempo; quando estava desligada, a contagem não foi computada. Não foi necessária manutenção para o horímetro.

Chave de fluxo: tal qual o horímetro, em termos de desempenho, registrou valores superiores aos medidores de velocidade, conforme mencionado anteriormente. No que diz respeito à parte da operação, a chave de fluxo funcionou normalmente, e não teve problemas de travar pelo acúmulo de sedimentos na palheta, como houve na Estação 2 - Areal. Também não houve necessidade de manutenção. 
A CAESB realiza captação de água do ribeirão Pipiripau com a finalidade de abastecimento público das regiões de Sobradinho/DF e Planaltina/DF. O sistema de captação, composto por dois conjuntos moto-bomba, é operado quase continuamente, em torno de 20 horas por dia, possibilitando a coleta de dados por um longo período.

Apresenta-se gráfico comparativo das vazões instantâneas registradas pelos equipamentos (em $\left.\mathrm{m}^{3} / \mathrm{h}\right)$ vs. tempo, tomando de exemplo o intervalo entre $1^{\circ}$ e 5 de novembro de 2013:

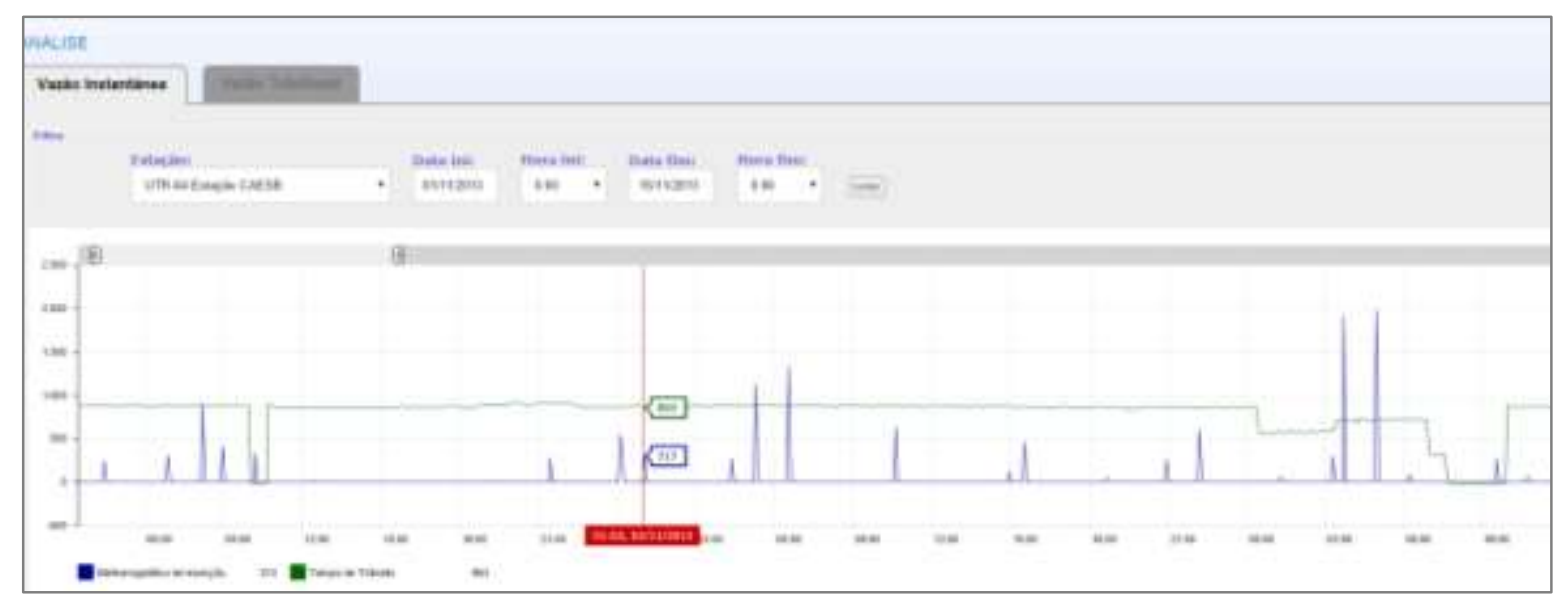

Figura C.27 - Gráfico dos dados de vazão instantânea - Estação Hidrométrica 4 - CAESB, entre os dias $1^{\circ}$ e 5/11/2013 (Fonte: http://ana.vector.com.br)

Na Estação 4 - CAESB foram instalados somente dois equipamentos: ultrassônico por tempo de trânsito, externo, tipo clamp-on (linha verde) e eletromagnético de inserção (linha azul). Em todo o período de funcionamento foram registradas 70.340 medições. Nesta estação, de uma maneira geral, verificou-se um funcionamento quase que integral do bombeamento pelas medições realizadas pelo equipamento ultrassônico, assinalado no gráfico acima pela linha verde. Já o eletromagnético de inserção registrou valores iguais a zero na maioria do tempo, com picos de medição com valores inferiores, iguais ou superiores ao ultrassônico, conforme pode ser observada na Figura anterior. Detalhase o desempenho, operação e manutenção de cada um desses dois equipamentos:

Ultrassônico por tempo de trânsito externo: no que diz aos registros de vazão, o equipamento fez basicamente três tipos de leitura (vide figura a seguir):

$\mathrm{V} 1$ = 0, quando o bombeamento estava desligado, em média de 3 a 4 horas/dia;

V2 = valores entre 400 e $600 \mathrm{~m} / \mathrm{h}$, quando havia o acionamento de apenas uma bomba de captação; $\mathrm{V} 3=800 \mathrm{~m}^{3} / \mathrm{h}$, aproximadamente, quando o sistema funcionada de forma plena, com o acionamento das duas bombas. 


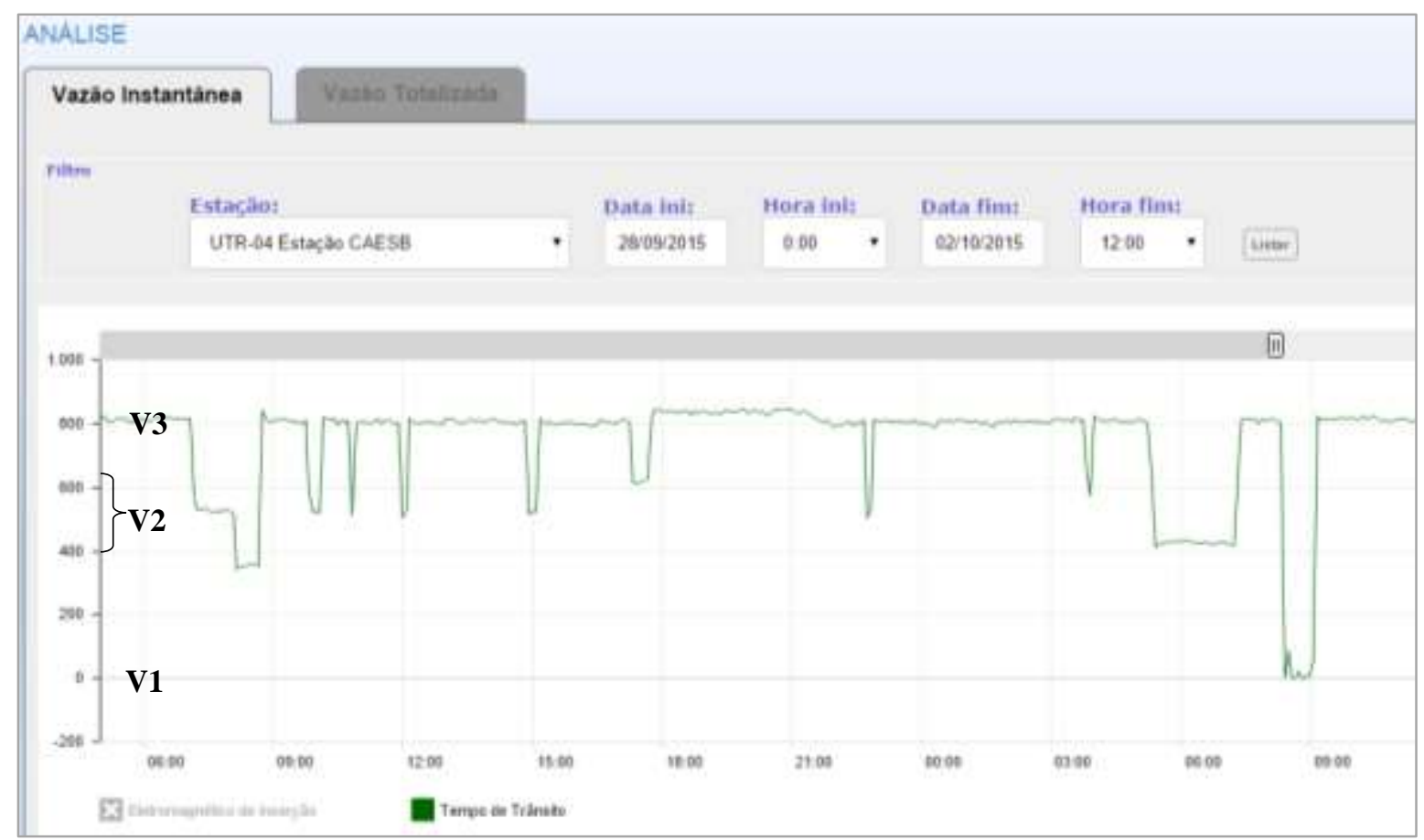

Figura C.28 - Gráfico dos dados de vazão instantânea do ultrassônico por tempo de trânsito - Estação 4 - CAESB, entre os dias 28/09 e 02/10/2015 (Fonte: http://ana.vector.com.br)

Em termos de desempenho, os valores registrados pelo ultrassônico são próximos aos do eletromagnético de carretel instalado da CAESB. Explicitando melhor, a referida Companhia forneceu informações de vazão instantânea medidas pelo carretel instalado na tubulação, leituras diárias efetuadas no horário de 24:00 horas, conforme demonstrado na planilha a seguir. O valor médio das leituras da CAESB foi de 228,2 1/s, ou seja, 821,5 m³/h. Já as leituras registradas pelo ultrassônico nestes horários, tiveram média de $800,9 \mathrm{~m} 3 / \mathrm{h}$, ou seja, uma diferença de $2,6 \%$ entre os medidores. 


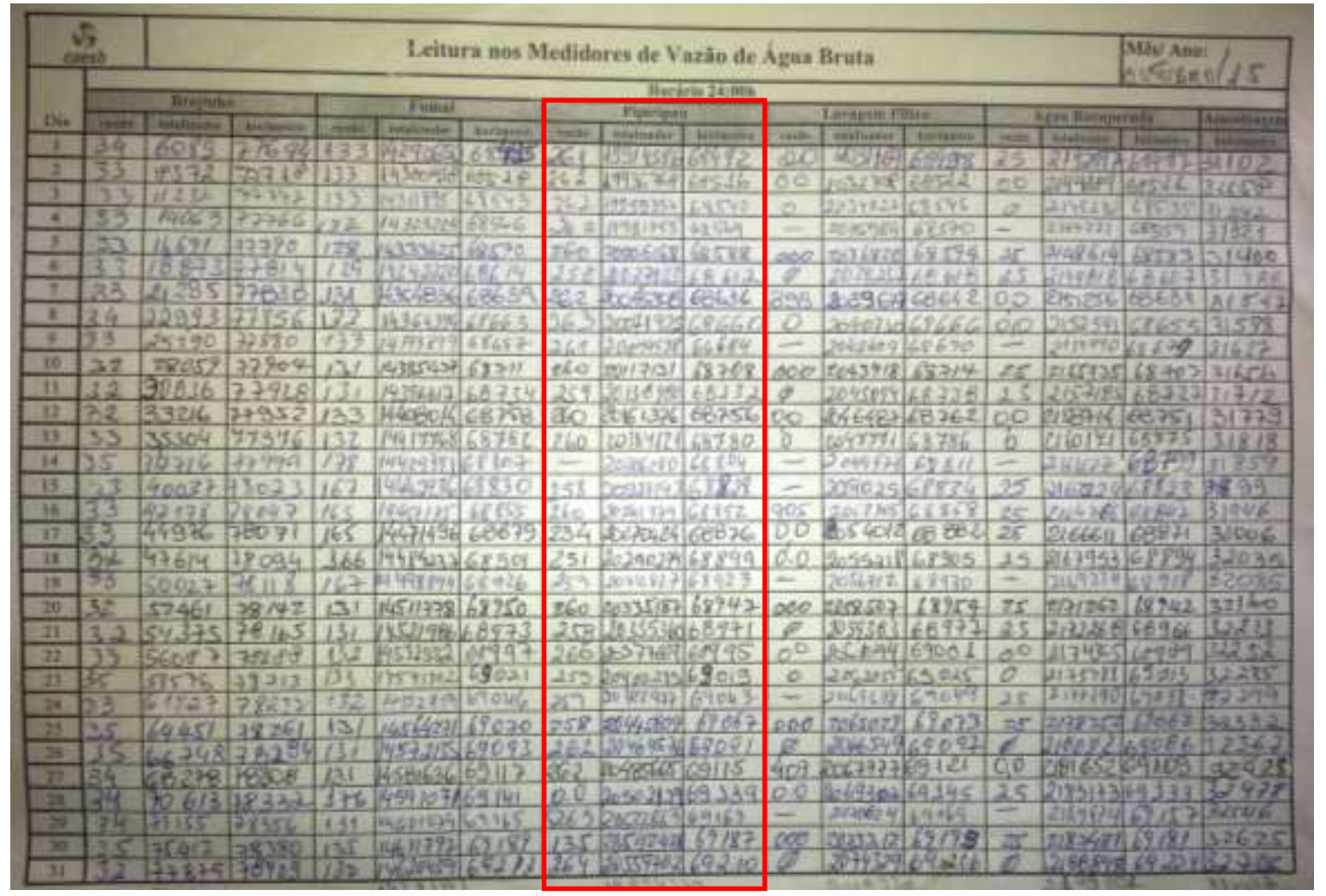

Figura C.29 - Planilha com leituras de vazão instantânea do medidor eletromagnético carretel instalado na ETA Pipiripau - mês outubro de 2015 (Fonte: CAESB)

No que diz respeito à operação, foram constatadas quedas de desempenho deste equipamento nas medições, a partir do dia 10 mês de novembro de 2013 (vide gráfico abaixo), apresentando valores iguais a zero em horas de funcionamento da bomba. Constatou-se o ressecamento do gel aplicado entre os sensores que emitem o sinal ultrassônico e o tubo. $\mathrm{O}$ gel acoplador acústico tem a função de excluir o ar da região de contato entre os transdutores e o tubo, eliminando assim ruídos e perda gradativa do sinal. Sendo o gel reaplicado em 26/11/2013, o instrumento voltou a funcionar normalmente.

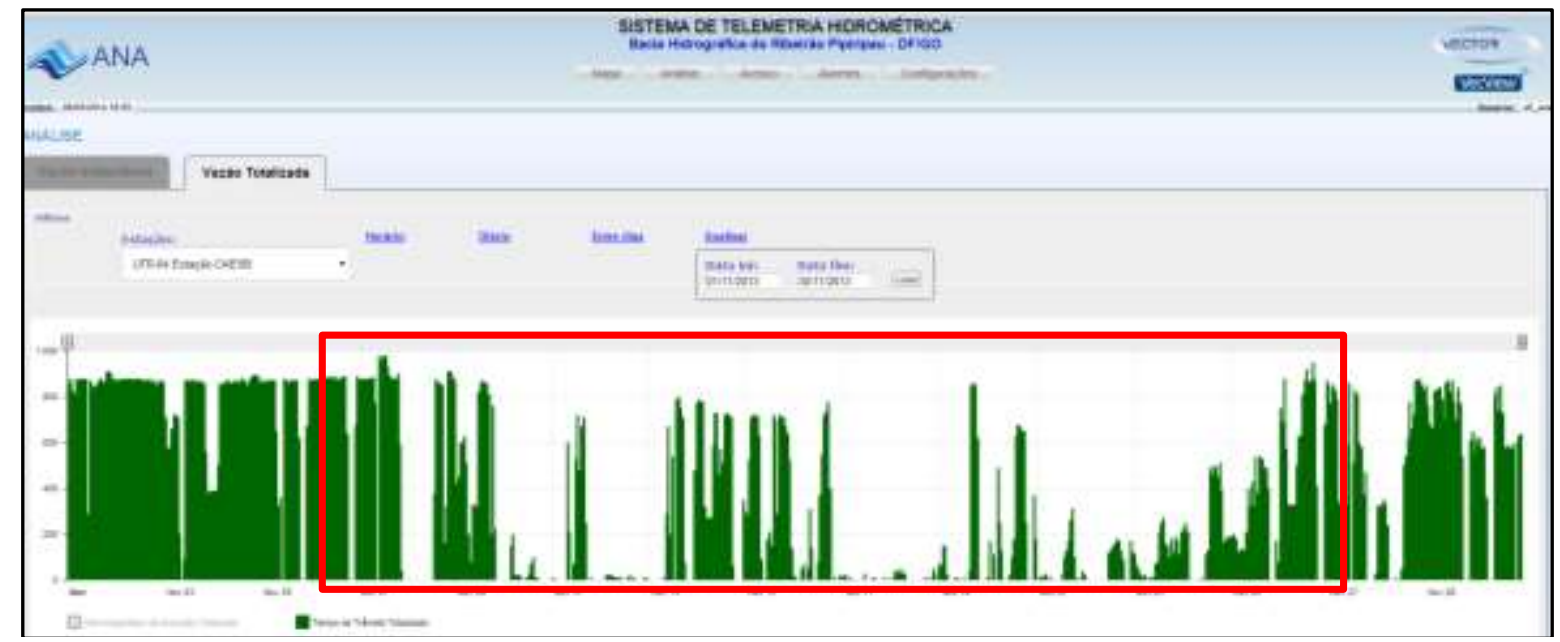

Figura C.30 - Gráfico dos dados de volume totalizado - Estação Hidrométrica 4 - CAESB, entre os dias $1^{\mathrm{o}}$ e 30/11/2013 (Fonte: http://ana.vector.com.br) 
Além do problema com o gel, em dezembro de 2014 houve um vazamento da tubulação da CAESB no local de instalação dos sensores do ultrassônico, tendo sido constatada instabilidade na leitura de vazão do medidor. Verificou-se a presença de água no interior dos sensores ultrassônicos, tendo sido retirados para manutenção em fábrica. Não havendo possibilidade de conserto, os mesmos foram substituídos.

Em relação à manutenção, após constatação de problemas de ressecamento do gel acoplador, o mesmo foi trocado mensalmente, não havendo mais problemas dessa natureza.

Eletromagnético de inserção: apresentou mais inconsistências nas medições nesta Estação do que nas Estações 1 - Mazurek e 2 - Areal, tendo registrado valores iguais a zero quando a bomba estava em funcionamento, provavelmente pela maior trepidação da tubulação e sensibilidade do sensor, conforme afirmou laudo técnico do fabricante. Em termos de manutenção, foi feita a limpeza periódica do equipamento, mensal, para evitar o acúmulo de sedimentos no sensor.

\section{C.3.5 Estação 5: Canal Santos Dumont}

A Associação dos Usuários do Canal Santos Dumont utiliza água do Ribeirão Pipiripau com a finalidade de irrigação. A água captada é conduzida por um canal até as propriedades dos associados, sendo, portanto, a única estação na qual serão testados equipamentos de medição para canal aberto. A comporta que controla a entrada de água no canal Santos Dummont é mantida aberta pela associação durante o ano todo, sendo possível a obtenção de dados de forma contínua. Durante os dois anos de funcionamento, de nov/13 a dez/15, observou-se que as vazões eram maiores no período chuvoso (novembro a março), uma vez que a vazão natural do ribeirão Pipiripau era maior, exercendo mais pressão na comporta de entrada para o canal, aumentando a velocidade e o nível da água no canal e, por consequência, a vazão no mesmo.

Apresenta-se gráfico comparativo das vazões instantâneas registradas pelos equipamentos, em $\mathrm{m}^{3} / \mathrm{h}$, ao longo do tempo, tomando como exemplo o período entre os dias 13 e 18 de outubro de 2015: 


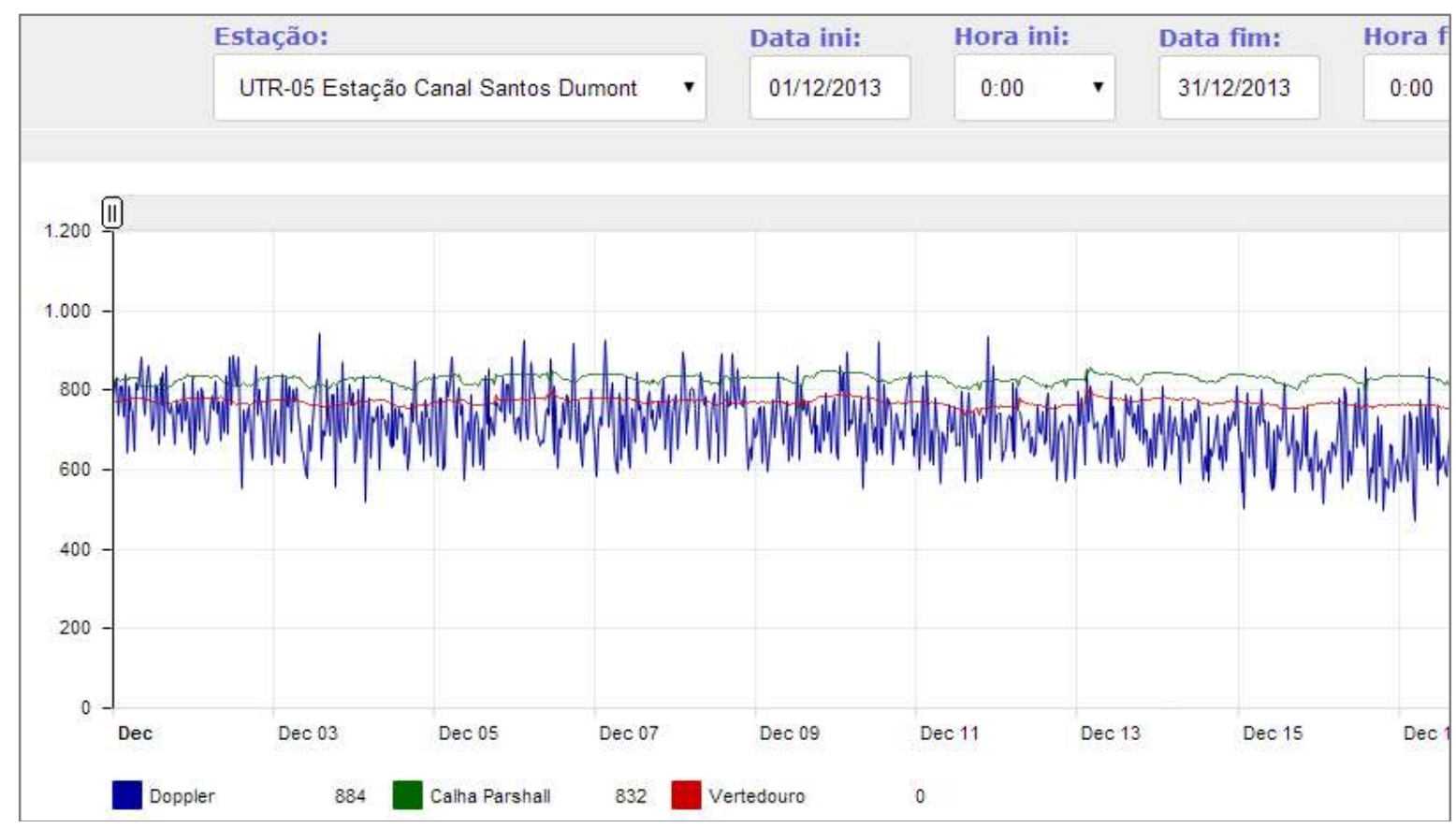

Figura C.31 - Gráfico dos dados de vazão instantânea - Estação Hidrométrica 5 - Santos Dumont, entre os dias $1^{\circ}$ e 17/12/2013 (Fonte: http://ana.vector.com.br)

Em todo o período de funcionamento foram totalizadas 210.240 medições. Dessas, foram descartadas as medições que tiveram falhas de algum equipamento, ou na transmissão dos dados. Dessa forma, foram contabilizados 140.579 registros. A calha Parshall (linha verde) apresentou média de 994,4 $\mathrm{m}^{3} / \mathrm{h}$ e desvio de $128,2 \mathrm{~m}^{3} / \mathrm{h}$. Já o ultrassônico por efeito doppler (linha azul) registrou valores médios mais próximos da calha Parshall, com $981,8 \mathrm{~m}^{3} / \mathrm{h}$ de média, mas com o maior desvio, de 223,9 $\mathrm{m}^{3} / \mathrm{h}$. Já o vertedouro apresentou valores com menor média, de $912,4 \mathrm{~m} 3 / \mathrm{h}$, e desvio de $158,5 \mathrm{~m}^{3} / \mathrm{h}$.

Não há, no canal, uma medição que seja tida como referência. Entretanto, para efeito comparativo, foram realizadas três medições utilizando medidor acústico de vazão, também por efeito doppler, denominado Flowtracker, nos dias 21/02/2014, 24/06/2014 e 03/07/2015, próximo à instalação da calha Parshall (vide figura a seguir). 

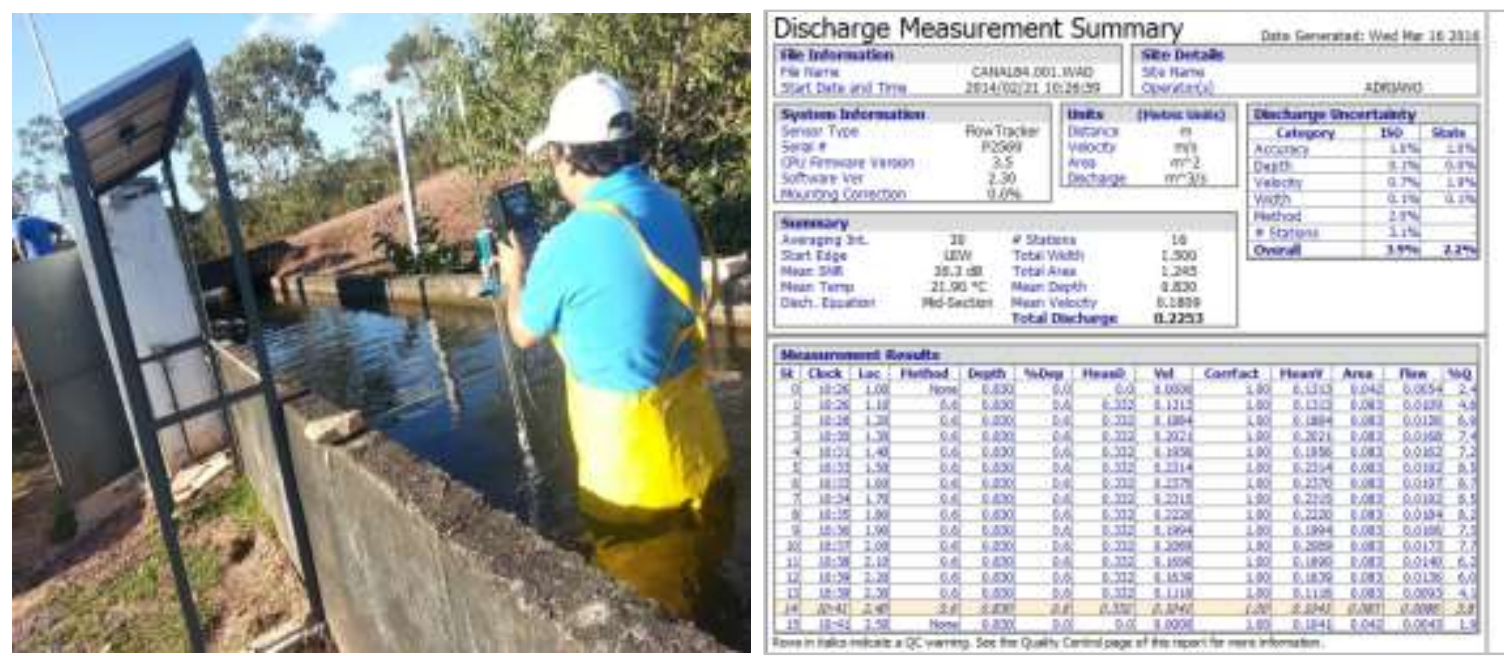

Figura C.32 - Medição de vazão no canal Santos Dumont utilizando medidor ultrassônico doppler denominado Flowtracker, em 21/02/2014 (relatório de medição à direita)

Segue tabela comparativa com os resultados dessas medições com os registros dos equipamentos:

Tabela C.1 - Comparação entre medições de vazão no canal Santos Dumont

\begin{tabular}{|c|c|c|c|c|c|c|c|}
\hline \multirow{2}{*}{$\begin{array}{c}\text { Data da } \\
\text { Medição }\end{array}$} & \multirow{2}{*}{$\begin{array}{c}\text { Flowtracker } \\
\text { Vazão 1 } \\
\left(\mathbf{m}^{3} / \mathbf{h}\right)\end{array}$} & \multicolumn{2}{|c|}{ Calha Parshall } & \multicolumn{2}{|c|}{ Vertedouro } & \multicolumn{2}{|c|}{ Ultrassônico } \\
\hline & & $\begin{array}{c}\text { Vazão } 2 \\
\left(\mathbf{m}^{3} / \mathbf{h}\right)\end{array}$ & $\begin{array}{c}\text { Dif. 1/2 } \\
(\%)\end{array}$ & $\begin{array}{c}\text { Vazão } 3 \\
\left(\mathbf{m}^{3} / \mathbf{h}\right)\end{array}$ & $\begin{array}{c}\text { Dif. 1/3 } \\
(\%)\end{array}$ & $\begin{array}{c}\text { Vazão } 4 \\
\left(\mathbf{m}^{3} / \mathbf{h}\right)\end{array}$ & $\begin{array}{c}\text { Dif. 1/4 } \\
(\%)\end{array}$ \\
\hline $\begin{array}{c}21 / 02 / 2014 \\
10: 27\end{array}$ & 811 & 860 & $6,0 \%$ & 760 & $-6,3 \%$ & 802 & $-1,1 \%$ \\
\hline $\begin{array}{c}24 / 06 / 2014 \\
16: 05\end{array}$ & 932 & 974 & $4,5 \%$ & 888 & $-4,7 \%$ & 903 & $-3,1 \%$ \\
\hline $\begin{array}{c}03 / 07 / 2015 \\
11: 44 h\end{array}$ & 1085 & 1050 & $-3,2 \%$ & 1028 & $-5,2 \%$ & 1079 & $-0,5 \%$ \\
\hline
\end{tabular}

Observa-se que os resultados dos equipamentos instalados apresentam valores próximos às medições in loco feitas com o medidor acústico, com diferença máxima de 6,3\%. O vertedouro apresentou os menores valores, tal qual comparativo geral, e será explanado a seguir. Já o ultrassônico doppler apresentou valores quase que idênticos, tendo em vista que o método de medição desse com o medidor acústico é o mesmo. Detalha-se o desempenho, operação e manutenção de cada um dos equipamentos instalados no canal Santos Dumont:

Ultrassônico por efeito doppler: no que diz respeito à resposta quanto aos valores medidos, apesar de este equipamento ter apresentado as maiores variações em termos de desvio, a média das vazões medidas corresponde a um valor próximo dos outros dois equipamentos., Tendo sido questionado ao fabricante do equipamento o porquê desses resultados, o mesmo elaborou laudo técnico informando que estas variações de velocidades são inerentes ao princípio de medição (efeito doppler) utilizado no elemento sensor, que possui maior sensibilidade para medição das velocidades, tendo em vista que 
responde a um sinal das partículas sólidas que acompanham o meio líquido. Em novembro de 2013, na tentativa de "amortizar" a variação de velocidades, alterou-se o tempo de medição de vazão instantânea (denominado “dumping”), que estava parametrizado em 30 segundos, passando a leitura a cada 5 minutos. Entretanto, não foi observada qualquer alteração nas variações.

No que diz respeito à operação, verificou-se logo no início da operação, em dezembro de 2013, uma diminuição dos valores de vazão medidos, tendo sido identificada interferência na medição pelo acúmulo gradual de limbo no elemento sensor do equipamento, proveniente de resíduos da vegetação que passa pelo canal. Dessa forma, definiu-se como manutenção preventiva a limpeza periódica do equipamento, mensal, não tendo sido identificado novos problemas.

Calha Parshall: em termos de resultado, todos os equipamentos apresentaram valores médio próximos, mas a calha foi a que teve menor desvio padrão nos valores de vazão instantânea medidos. No que tange à operação, a calha foi projetada para trabalhar em superfície livre, com parametrização da fórmula de cálculo sem considerar afogamento. Em fevereiro de 2015 houve uma cheia no ribeirão Pipiripau e a água derivada para o canal atingiu o maior nível nos dois anos de operação, passando pela garganta da calha Parshall com altura de $88 \mathrm{~cm}$ (vide figura abaixo), sendo que o canal atinge altura de 92cm. Em 19/02/2015, foi registrada a maior vazão pela calha, com $1582 \mathrm{~m} 3 / \mathrm{h}$. Concluindo, não houve problemas que necessitassem de manutenção na calha.
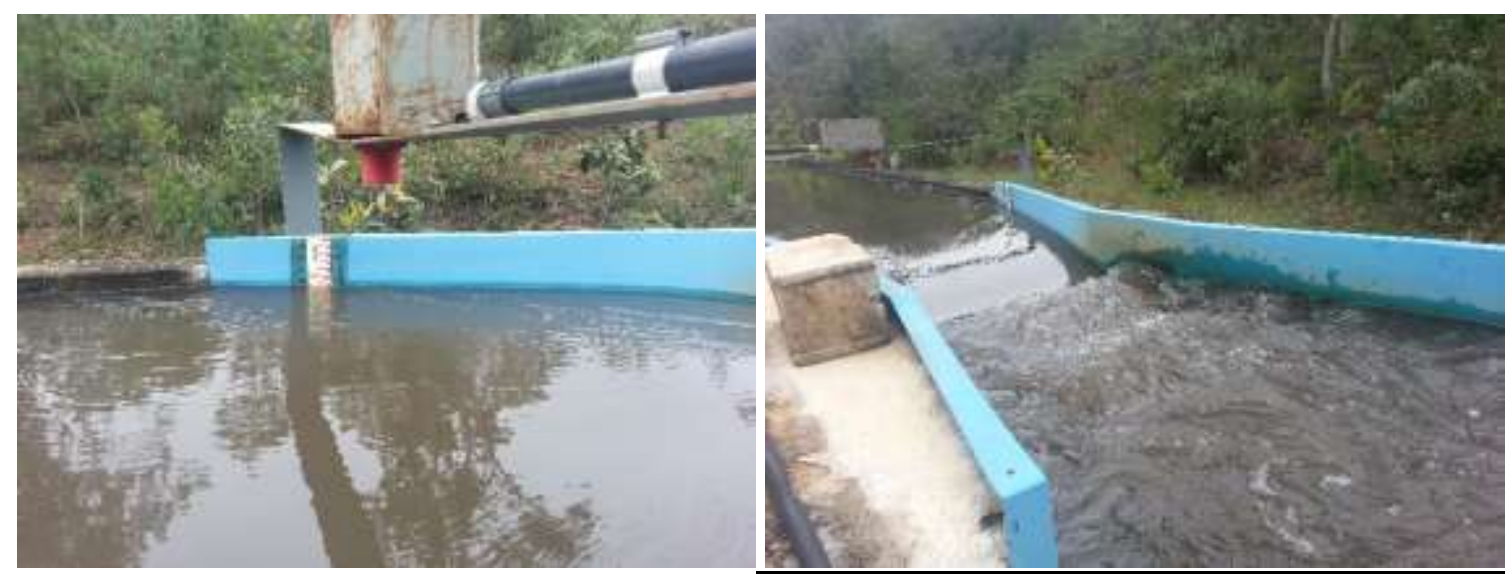

Figura C.33 - Calha Parshall com maior nível d'água nos dois anos de operação, em 19 de fevereiro de 2015, sem afogamento

Ultrassônico de nível: equipamento instalado em conjunto com a calha para registro dos valores medidos, conforme pode ser observado na figura anterior, instalado na parte superior da calha, sem contato com o meio líquido. O ultrassônico registrou os valores programados, não havendo quaisquer problemas de operação e manutenção. 
Vertedouro retangular de soleira delgada: assim como a calha Parshall, o vertedouro também foi projetado para funcionamento como superfície livre, ou seja, sem afogamento. Pelo projeto de hidráulica, em consequência da baixa declividade do canal, para evitar afogamento pelo efeito de remanso, instalou-se o vertedouro 542,5 metros a jusante da calha Parshall, distância esta percorrendo a linha do canal.

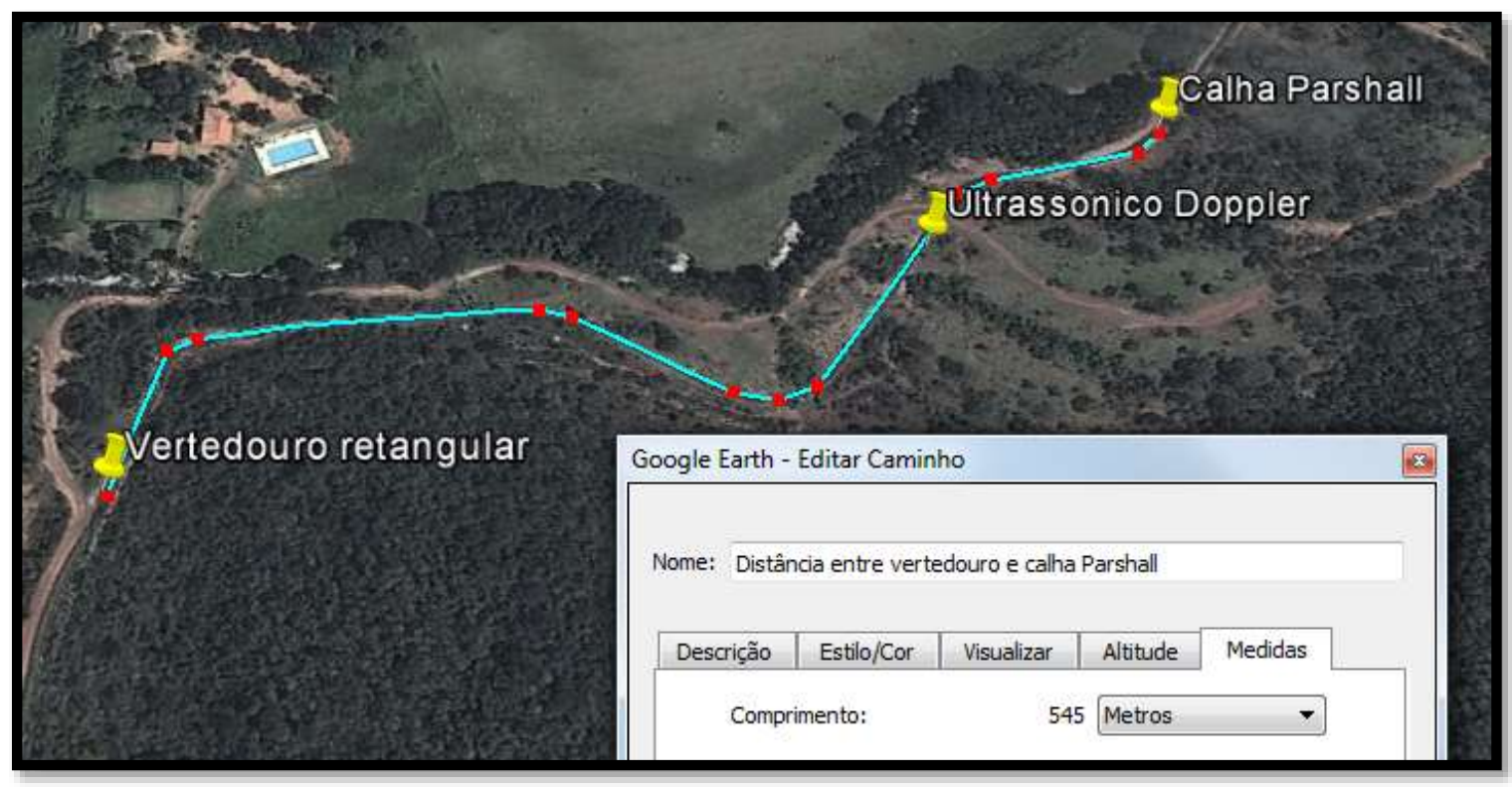

Figura C.34 - Localização de instalação dos equipamentos no canal Santos Dumont

Com a instalação dos medidores, houve uma elevação de nível d'água do canal nesse trecho entre a calha e o vertedouro, pelo barramento que os próprios dispositivos fazem para funcionarem como medidores de vazão. Dessa forma, a partir do mês de maio de 2014, percebeu-se vazamentos em algumas juntas de dilatação no trecho entre a calha e o vertedouro (vide figura a seguir), causadas pelo aumento de nível d'água no canal e pelo ressecamento dessas juntas, uma vez que o canal foi construído em 1963 e não teve substituição dessas juntas desde sua construção. Dessa forma, com a perda de água nessas juntas, um comparativo de valores de vazão medidos pelo vertedouro com a calha Parshall e o ultrassônico doppler, instalados a montante, fica comprometido. Pelo menos, há uma coerência no que tange aos valores médios registrados pelo vertedouro apresentarem um resultado final 8,5\% inferiores ao da calha Parshall e 7\% inferiores ao do ultrassônico doppler. 


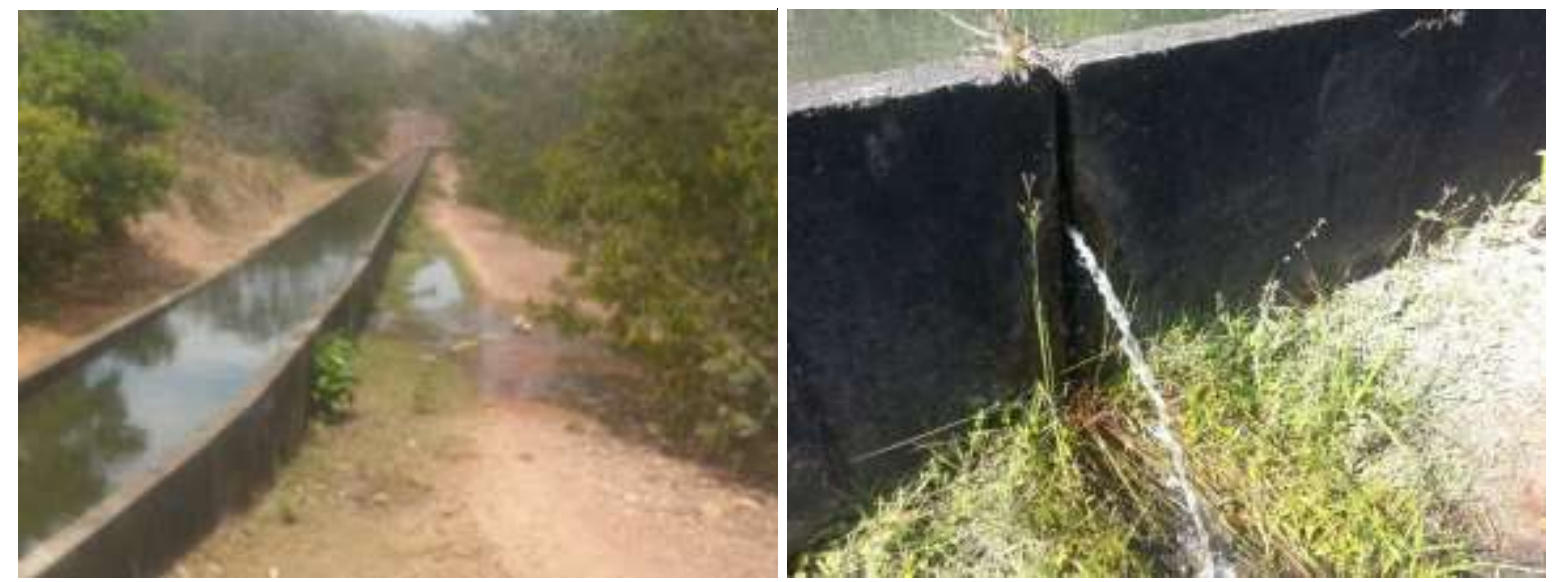

Figura C.35 - Vazamentos em juntas de dilatação entre a calha Parshall e o vertedouro

No que concerne à operação, com a cheia do Pipiripau em fevereiro de 2015, onde vertedouro ficou em regime afogado por 20 dias (vide foto a seguir) registrando valores na ordem de $1550 \mathrm{~m} / \mathrm{h}$, superiores ao demais que registraram vazões em torno de $1200 \mathrm{~m} 3 / \mathrm{h}$.
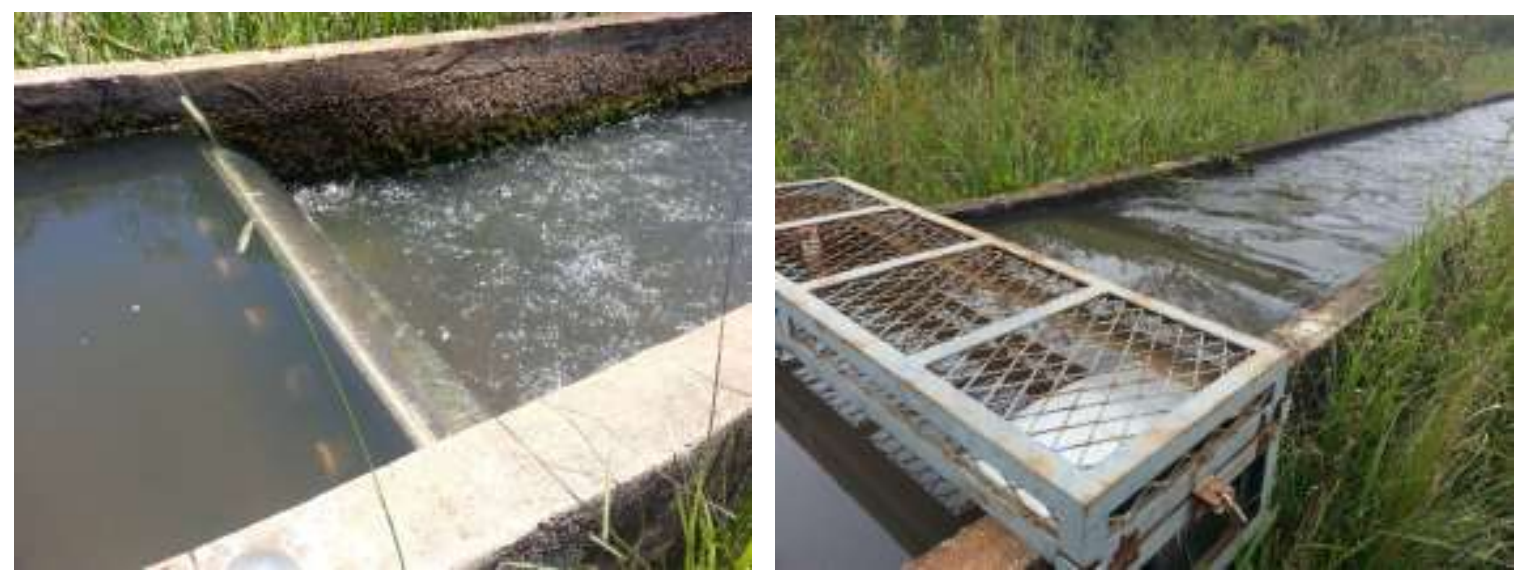

Figura C.36 - Vertedouro em regime de operação normal (esq.), em 23/10/2015, e vertedouro afogado na $2^{a}$ quinzena de fevereiro de 2015 (dir.), foto tirada em 19/02/2015

No dia 3 de julho de 2015, percebeu-se uma diminuição brusca nas medições registradas pelo vertedouro, tendo sido constatado que a crista do mesmo, formada por uma chapa de alumínio, havia sido retirada, provavelmente por vandalismo (vide figura a seguir).

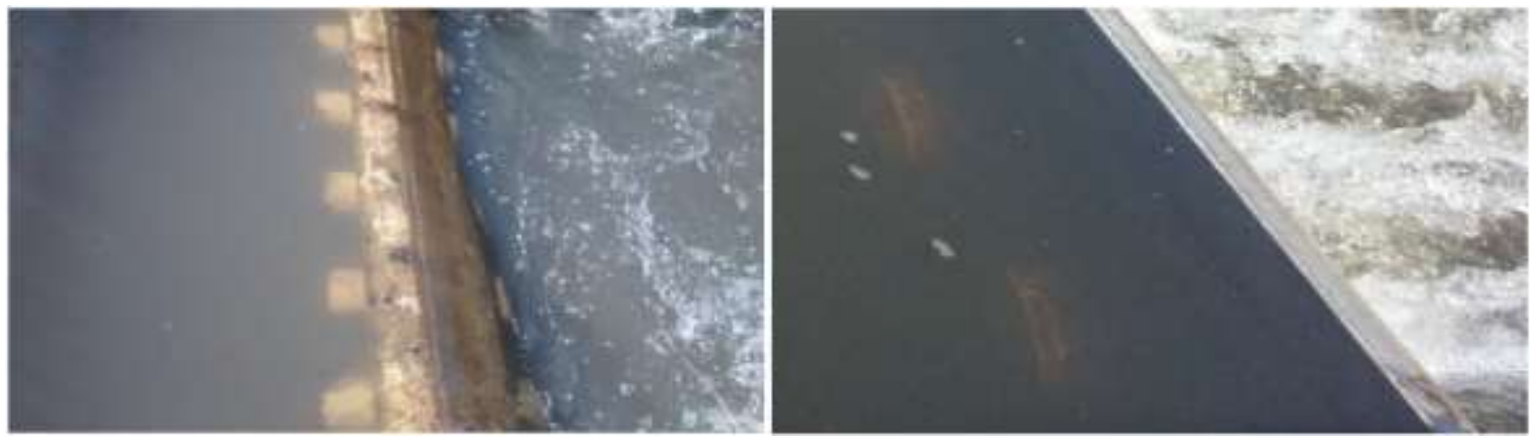

Figura C.37 - Vertedouro sem a crista de alumínio (esq.), e com a crista reinstalada (dir.) 
Após reinstalação da crista do vertedouro, o mesmo passou a medir valores coerentes com a Calha Parshall, conforme destaque em laranja no gráfico da figura a seguir, que compara os valores instantâneos da Calha Parshall (em verde) e do vertedouro (em vermelho). Em relação à manutenção, fora o problema de reinstalação da crista, não houve necessidade de interferência no dispositivo após sua instalação.

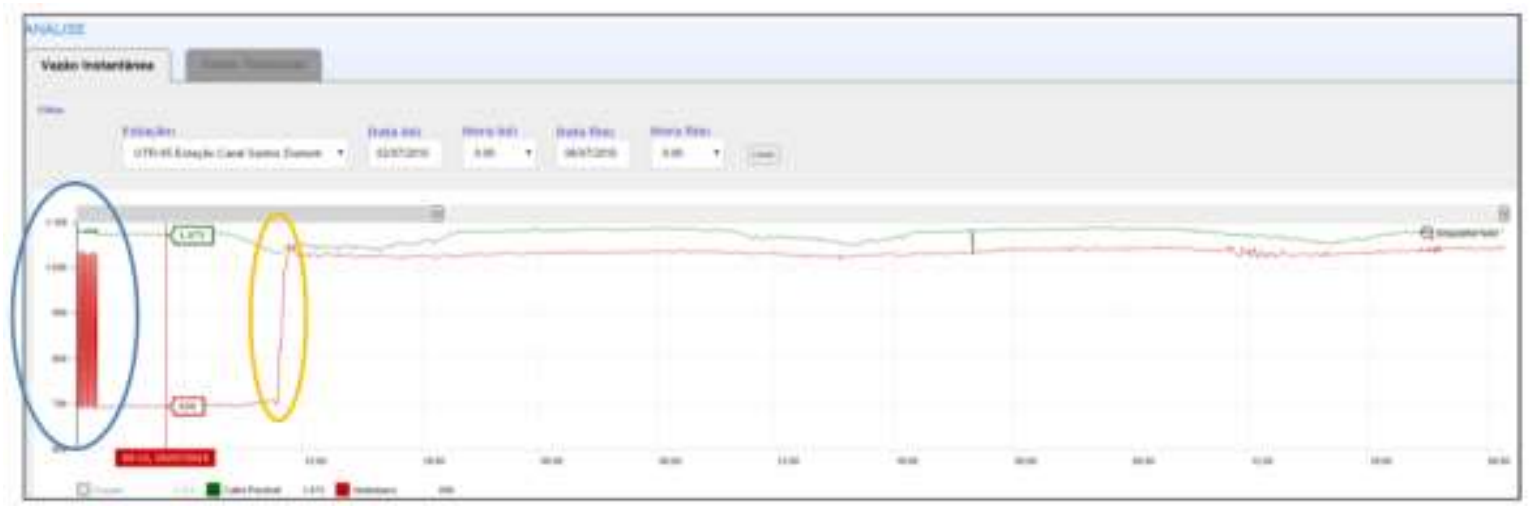

Figura C.38 - Gráfico comparativo de medições do vertedouro com a calha Parshall, em julho de 2015. Círculo azul: retirada da chapa; círculo laranja: reinstalação da chapa. (Fonte: http://ana.vector.com.br)

Ultrassônico de nível: equipamento instalado em conjunto com a calha para registro dos valores medidos, conforme pode ser observado na figura anterior, instalado na parte superior da calha, sem contato com o meio líquido. O ultrassônico registrou os valores programados, não havendo quaisquer problemas de operação e manutenção.

Sensor hidrostático: equipamento instalado em conjunto com o vertedouro para registro de nível da água por pressão hidrostática, instalado no fundo do canal, ou seja, em regime de submersão. O sensor teve problemas de funcionamento no início, entre os meses de novembro de 2013 a julho de 2014, parando o funcionamento por três vezes, até a queima do sensor. Todos os problemas foram de origem elétrica, por surto de descarga atmosférica. Após instalação de um suporte do tipo gaiola de Faraday, não houve mais problemas de funcionamento do equipamento. No que tange à manutenção, por estar submerso, foi realizada retirada para limpeza mensal, para evitar interferências nas medições por acúmulo de lodo.

RESUMO: no apêndice D, apresentam-se três tabelas, com informações gerais de funcionamento, preço, desempenho, operação, manutenção, vantagens desvantagens e recomendações gerais de cada um dos equipamentos de medição de vazão estudados na revisão teórica e bibliográfica e pesquisados na parte experimental do projeto. Esse apêndice constará como adicional ao SSD. 


\section{APÊNDICE D - TABELAS RESUMO DOS EQUIPAMENTOS DE MEDIÇÃO DE VAZÃO}

Tabela D.1 - Tabela resumo dos equipamentos de medição de vazão para condutos forçados (tubulação sob pressão)

\begin{tabular}{|c|c|c|c|c|c|c|}
\hline \multirow{3}{*}{\begin{tabular}{|l|}
\multicolumn{1}{|c|}{ Equipamento } \\
$\begin{array}{l}\text { 1. Eletromagnético de } \\
\text { carretel }\end{array}$ \\
\end{tabular}} & \multirow{9}{*}{\begin{tabular}{|l}
\multicolumn{1}{|c|}{ Funcionamento } \\
- Baseado na lei da indução eletro- \\
magnética de Faraday; \\
- A passagem de um fluido (condutor \\
elétrico) num campo magnético gera \\
uma corrente elétrica proporcional à \\
velocidade desse fluido; \\
- Os eletrodos se localizam de um ex- \\
tremo a outro da tubulação, sem con- \\
tato com o fluido, calculando veloci- \\
dade média de toda a seção.
\end{tabular}} & \multicolumn{2}{|c|}{ Preço } & \multirow{3}{*}{\begin{tabular}{l}
\multicolumn{1}{c|}{ Vantagens } \\
- Maior precisão: erro \\
varia $\pm 0,5 \%$;
\end{tabular}} & \multirow{4}{*}{\begin{tabular}{l}
\multicolumn{1}{c|}{ Desvantagens } \\
- Exige trechos retilí- \\
neos à montante e à \\
jusante para instala- \\
ção;
\end{tabular}} & \multirow{8}{*}{\begin{tabular}{l}
\multicolumn{1}{|c|}{ Recomendações gerais } \\
- Instalação dos displays no painel \\
elétrico ou a devida proteção dos \\
mesmos, quando não for possível; \\
- Escolha de local para instalação é \\
fundamental para garantia de resul- \\
tados confiáveis. Exige trechos re- \\
tilíneos à montante (5X o diâmetro) \\
e à jusante (2X o diâmetro) para \\
instalacão.
\end{tabular}} \\
\hline & & $\phi(\mathbf{m m})$ & $\mathbf{R} \$$ & & & \\
\hline & & 50 & 14.700 & & & \\
\hline & & 80 & 15.500 & \multirow{14}{*}{$\begin{array}{l}\text { - Mede velocidade mé- } \\
\text { dia de toda a seção } \\
\text { transversal, podendo ser } \\
\text { adotado como referên- } \\
\text { cia; } \\
\text { - Não há custo de manu- } \\
\text { tenção; } \\
\text { - Dois tipos: a bateria } \\
\text { (sem necessidade de } \\
\text { energia) e elétrico. }\end{array}$} & & \\
\hline & & 100 & 15.800 & & \multirow{13}{*}{$\begin{array}{l}\text { - Deve-se seccionar a } \\
\text { tubulação para insta- } \\
\text { lar o carretel entre } \\
\text { flanges ou juntas; } \\
\text { - Preço elevado, se } \\
\text { comparado com ou- } \\
\text { tros equipamentos. }\end{array}$} & \\
\hline & & 150 & 17.400 & & & \\
\hline & & 200 & 20.200 & & & \\
\hline & & 250 & 25.800 & & & \\
\hline & & 300 & 28.500 & & & \\
\hline & & 350 & 31.100 & & & \\
\hline & & 400 & 33.400 & & & \\
\hline & & 500 & 44.400 & & & \\
\hline & & 600 & 50.300 & & & \\
\hline & & 700 & 60.400 & & & \\
\hline & & 800 & 70.100 & & & \\
\hline & & 900 & 84.400 & & & \\
\hline & & 1000 & 101.400 & & & \\
\hline $\begin{array}{l}\text { 2. Eletromagnético de } \\
\text { inserção }\end{array}$ & $\begin{array}{l}\text { - Baseado na lei da indução eletro- } \\
\text { magnética de Faraday; } \\
\text { - A passagem de um fluido (condutor } \\
\text { elétrico) num campo magnético gera } \\
\text { uma corrente elétrica proporcional à } \\
\text { velocidade desse fluido; } \\
\text { - Os eletrodos se situam próximos, } \\
\text { calculando a velocidade de forma } \\
\text { pontual; } \\
\text { - Define um fator "K": relação entre a } \\
\text { velocidade pontual e a média da tubu- } \\
\text { lação. }\end{array}$ & \multicolumn{2}{|c|}{$\mathrm{R} \$ 30.000-35.000$} & $\begin{array}{l}\text { - Para tubulações com } \\
\text { diâmetros maiores que } \\
400 \mathrm{~mm} \text {, é mais barato } \\
\text { que o carretel. }\end{array}$ & $\begin{array}{l}\text { - Problemas com ar, } \\
\text { sujeira e trepidação: } \\
\text { medidas incoerentes; } \\
\text { - Fabricantes não re- } \\
\text { comendam para água } \\
\text { bruta; } \\
\text { - Deve-se furar tubu- } \\
\text { lação para instalação; } \\
\text { - Manutenção cons- } \\
\text { tante. }\end{array}$ & $\begin{array}{l}\text { - Recomendada a instalação so- } \\
\text { mente com aval de técnico especia- } \\
\text { lizado, que deve fazer traçar perfil } \\
\text { de velocidade e definir fator "k"; } \\
\text { - Deve-se fazer testes de operação } \\
\text { antes de instalação definitiva; } \\
\text { - Deve-se realizar manutenção pe- } \\
\text { riódica para limpeza dos eletrodos. }\end{array}$ \\
\hline
\end{tabular}




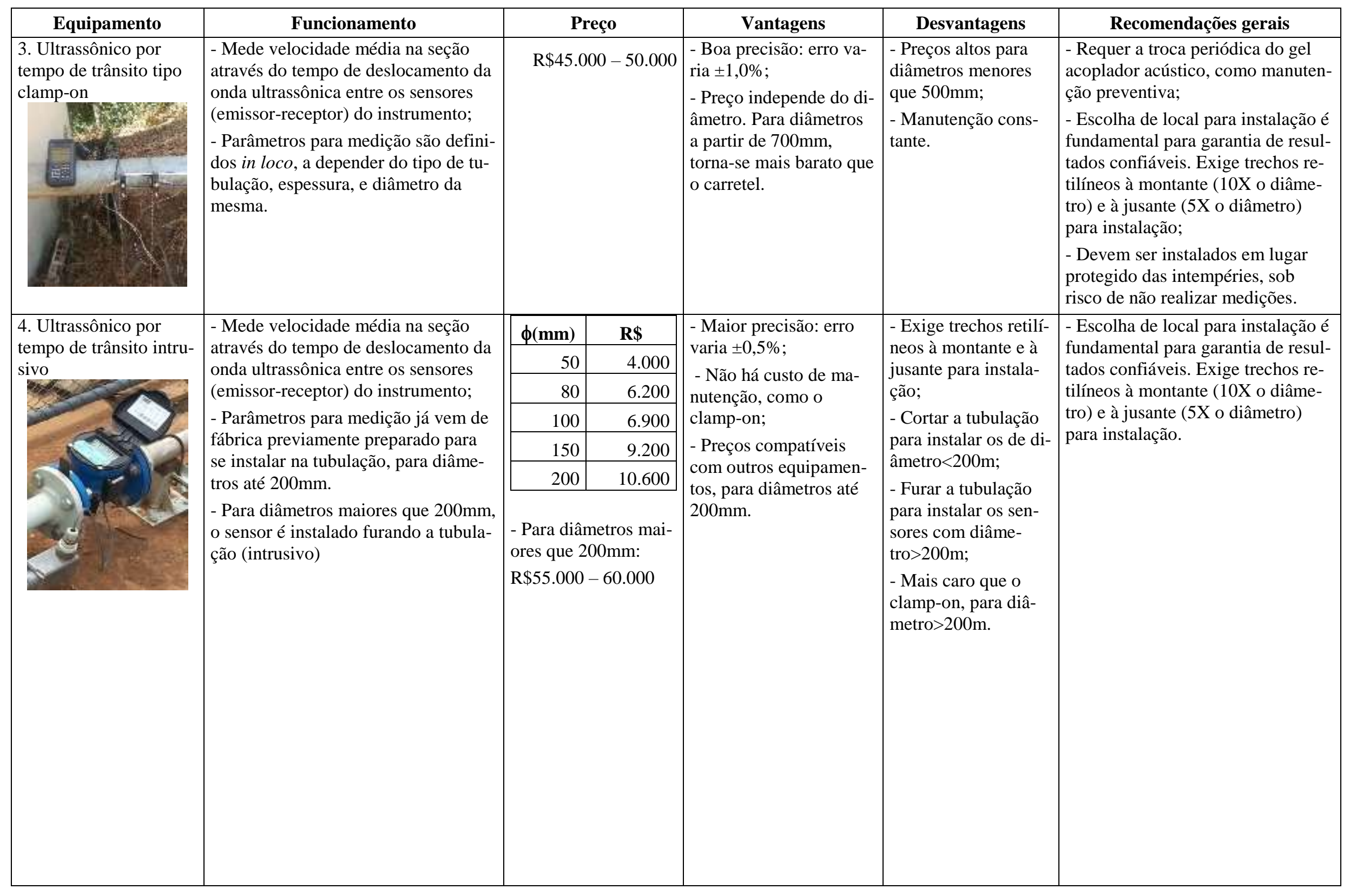




\begin{tabular}{|c|c|c|c|c|c|}
\hline Equipamento & Funcionamento & Preço & Vantagens & Desvantagens & Recomendações gerais \\
\hline 61 & $\begin{array}{l}\text { - o Annubar é uma variação do Tubo } \\
\text { de Pitot, e possui } 5 \text { furos para entrada } \\
\text { de água, perfazendo a velocidade mé- } \\
\text { dia em toda a tubulação; } \\
\text { - o Pitot possui } 1 \text { furo e calcula define } \\
\text { um fator "K": relação entre a veloci- } \\
\text { dade pontual e a média da tubulação. }\end{array}$ & & $\begin{array}{l}\text { o diâmetro da tubulação } \\
\text { e possui preços compatí- } \\
\text { veis para diâmetros mai- } \\
\text { ores que } 500 \mathrm{~mm} \text {. }\end{array}$ & $\begin{array}{l}\text { ção; } \\
\text { - Deve-se furar tubu- } \\
\text { lação para instalação; } \\
\text { - Manutenção cons- } \\
\text { tante. }\end{array}$ & $\begin{array}{l}\text { mento de ar na tubulação; } \\
\text { - Requer manutenção periódica } \\
\text { para limpeza dos furos; } \\
\text { - Instalação deve ser feita por téc- } \\
\text { nico especializado, p/traçar perfil } \\
\text { de velocidade e definir fator "k" } \\
\text { (Pitot); } \\
\text { - Recomenda-se instalar em locais } \\
\text { que se tenha equipe técnica de ma- } \\
\text { nutenção, tais como indústrias e } \\
\text { comp. de saneamento. }\end{array}$ \\
\hline $\begin{array}{l}\text { 6. Transmissores de } \\
\text { pressão diferencial tipo } \\
\text { orifício, bocal de vazão } \\
\text { ou Venturi }\end{array}$ & $\begin{array}{l}\text { Vazão calculada pela diferença de } \\
\text { pressão entre os pontos de montante e } \\
\text { jusante; } \\
\text { A medição da velocidade no escoa- } \\
\text { mento se dá através da diminuição da } \\
\text { pressão proporcional ao aumento da } \\
\text { velocidade, através da redução do di- } \\
\text { âmetro, numa determinada seção. }\end{array}$ & $\begin{array}{c}\mathrm{R} \$ 10.000-15.000 \\
\text { (para diâmetros até } \\
300 \mathrm{mmm} \text { ) }\end{array}$ & $\begin{array}{l}\text { - Precisão razoável: com } \\
\text { erro de } \pm 2,5 \% \text {; } \\
\text { - Preços compatíveis } \\
\text { com outros equip. de di- } \\
\text { âmetro até } 300 \mathrm{mmm} ;\end{array}$ & $\begin{array}{l}\text { - Exige trechos retilí- } \\
\text { neos à montante e à } \\
\text { jusante para instala- } \\
\text { ção; } \\
\text { - Deve-se furar tubu- } \\
\text { lação para instalação; } \\
\text { - Manutenção cons- } \\
\text { tante; } \\
\text { - Pouco robusto, } \\
\text { pode acarretar pro- } \\
\text { blemas de operação } \\
\text { como desconfigura- } \\
\text { ção }\end{array}$ & $\begin{array}{l}\text { - A tubulação deve estar sempre } \\
\text { cheia, senão pode medir diferenças } \\
\text { de pressão causadas por enchi- } \\
\text { mento de ar na tubulação; } \\
\text { - Requer manutenção periódica } \\
\text { para limpeza dos furos e eventuais } \\
\text { problemas de funcionamento; } \\
\text { - Recomenda-se instalar em locais } \\
\text { que se tenha equipe técnica de ma- } \\
\text { nutenção, tais como indústrias e } \\
\text { comp. de saneamento. }\end{array}$ \\
\hline
\end{tabular}




\begin{tabular}{|c|c|c|c|c|c|c|}
\hline \multirow{10}{*}{$\begin{array}{l}\text { 7. Hidrômetro tipo } \\
\text { Woltmann ou tangen- } \\
\text { cial }\end{array}$} & Funcionamento & \multicolumn{2}{|c|}{ Preço } & Vantagens & Desvantagens & Recomendações gerais \\
\hline & \multirow{9}{*}{$\begin{array}{l}\text { - Vazão calculada no próprio instru- } \\
\text { mento (relojoaria) por processo me- } \\
\text { cânico com peças móveis (turbina) e } \\
\text { registro de pulso elétrico a cada volta } \\
\text { completa da peça. }\end{array}$} & $\phi(\mathbf{m m})$ & $\mathbf{R} \$$ & \multirow{9}{*}{$\begin{array}{l}\text { - Menor preço, se com- } \\
\text { parado com outros } \\
\text { equip. de diâmetro até } \\
\text { 300mmm. }\end{array}$} & \multirow{9}{*}{$\begin{array}{l}\text { - Precisão não pode } \\
\text { ser definida; } \\
\text { - Foi idealizado para } \\
\text { água tratada e adap- } \\
\text { tado para a água } \\
\text { bruta; não possui ga- } \\
\text { rantia de bom funcio- } \\
\text { namento; } \\
\text { - Possui partes mó- } \\
\text { veis, em contato com } \\
\text { o fluido, a medição } \\
\text { pode ser prejudicada } \\
\text { pelos sólidos na água } \\
\text { bruta; } \\
\text { - Não há dados sobre } \\
\text { duração e longevi- } \\
\text { dade; } \\
\text { - Manutenção cons- } \\
\text { tante. }\end{array}$} & \multirow{9}{*}{$\begin{array}{l}\text { - Para água bruta, deve-se instalar } \\
\text { filtro de linha, a montante do medi- } \\
\text { dor, para diminuir problemas de } \\
\text { sólidos afetarem o medidor; } \\
\text { - Requer manutenção periódica } \\
\text { para limpeza do filtro de linha, sob } \\
\text { risco de não fazer leituras ou de } \\
\text { medir a menos, por acúmulo de se- } \\
\text { dimentos; } \\
\text { - Para irrigantes, por exemplo, é re- } \\
\text { comendável para aqueles que já fa- } \\
\text { zem a filtragem da água bruta para } \\
\text { não prejudicar o sistema de irriga- } \\
\text { ção, como os processos de goteja- } \\
\text { mento e micro aspersão; } \\
\text { - Em regiões de conflito, onde se } \\
\text { requer precisão de medida para re- } \\
\text { gulação do uso, não é recomendá- } \\
\text { vel a instalação desse dispositivo. }\end{array}$} \\
\hline & & 50 & 1.800 & & & \\
\hline & & 80 & 3.500 & & & \\
\hline & & 100 & 4.100 & & & \\
\hline & & 150 & 4.700 & & & \\
\hline & & 200 & 5.400 & & & \\
\hline & & 250 & 6.300 & & & \\
\hline & & 300 & 11.300 & & & \\
\hline & & & & & & \\
\hline
\end{tabular}


Tabela D.2 - Tabela resumo dos equipamentos de medição de vazão para superfície livre (canais abertos)

\begin{tabular}{|c|c|c|c|c|c|}
\hline Equipamento & Funcionamento & Preço & Vantagens & Desvantagens & Recomendações gerais \\
\hline 8. Vertedouros & $\begin{array}{l}\text { - Medidores de regime crítico, que } \\
\text { provocam um escoamento onde } \\
\text { existe somente uma relação entre a } \\
\text { altura (H) e a vazão }(\mathrm{Q}) \text {; } \\
\text { - Cálculo pela equação do vertedouro, } \\
\text { onde a vazão Q tem uma relação ex- } \\
\text { ponencial com o nível d'água }(\mathrm{H}) \text {. }\end{array}$ & $\begin{array}{l}\quad \mathrm{R} \$ 7.900 \\
\text { Referência: verte- } \\
\text { douro retangular de } \\
\text { soleira delgada (1m } \\
\text { de largura) }\end{array}$ & $\begin{array}{l}\text { - Baixo custo em rela- } \\
\text { ção a outros medidores } \\
\text { de superfície livre; } \\
\text { - Solução simples e ade- } \\
\text { quada para medição de } \\
\text { vazão em dutos circula- } \\
\text { res e pequenos canais }\end{array}$ & $\begin{array}{l}\text { - Instalação: feita por } \\
\text { profissional especia- } \\
\text { lizado; } \\
\text { - Obra civil: fluxo in- } \\
\text { terrompido ou desvi- } \\
\text { ado por } 7 \text { dias (mí- } \\
\text { nimo); } \\
\text { - Riscos de afoga- } \\
\text { mento em canais } \\
\text { com largura superior } \\
\text { a } 1 \text { metro; } \\
\text { - Medição contínua: } \\
\text { deve ser instalado } \\
\text { um sensor de nível } \\
\text { auxiliar. }\end{array}$ & $\begin{array}{l}\text { Instalação deve ser criteriosa, feita } \\
\text { por profissional: o escoamento } \\
\text { deve estar livre, com as bordas bem } \\
\text { talhadas, na posição horizontal, } \\
\text { sendo que toda a água deve escoar } \\
\text { unicamente pelo vertedouro. } \\
\text { - Solução simples e adequada para } \\
\text { medição de dutos circulares e pe- } \\
\text { quenos canais. Ex: lançamentos de } \\
\text { efluentes domésticos e industriais; } \\
\text { ETAs (abastecimento público). }\end{array}$ \\
\hline $\begin{array}{l}\text { 9. Calhas Parshall e } \\
\text { Palmer -Bowlus }\end{array}$ & $\begin{array}{l}\text { - Medidores de regime crítico, que } \\
\text { provocam um escoamento onde } \\
\text { existe somente uma relação entre a } \\
\text { altura (H) e a vazão (Q); } \\
\text { - Calha Parshall: canais retangulares; } \\
\text { Calha Palmer-Bowlus: apresenta se- } \\
\text { ção semicircular, para instalação di- } \\
\text { reta em tubulações } \\
\text { - Cálculo pela equação própria das } \\
\text { calhas Parshall e Palmer, onde a va- } \\
\text { zão Q tem uma relação exponencial } \\
\text { com o nível d'água (H). }\end{array}$ & \begin{tabular}{l}
\multicolumn{1}{|c|}{$\mathrm{R} \$ 11.900$} \\
Referência: Calha \\
Parshall apropriada \\
para 1m de largura
\end{tabular} & $\begin{array}{l}\text { - Confiabilidade dos re- } \\
\text { sultados, com erro da } \\
\text { ordem de } \pm 1,0 \% \text {; } \\
\text { - Robustez, durabilidade } \\
\text { e sem custo de manuten- } \\
\text { ção. }\end{array}$ & $\begin{array}{l}\text { - Custo maior para } \\
\text { canais com base me- } \\
\text { nor que 1m de lar- } \\
\text { gura; } \\
\text { Instalação: feita por } \\
\text { profissional especia- } \\
\text { lizado; } \\
\text { - Obra civil: fluxo in- } \\
\text { terrompido ou desvi- } \\
\text { ado por } 7 \text { dias (mí- } \\
\text { nimo); } \\
\text { - Medição contínua: } \\
\text { deve ser instalado } \\
\text { um sensor de nível } \\
\text { auxiliar. }\end{array}$ & $\begin{array}{l}\text { - Instalação deve ser criteriosa, } \\
\text { feita por profissional, principal- } \\
\text { mente no que tange à horizontali- } \\
\text { dade. Qualquer diferença de nível } \\
\text { pode provocar erros na medição; } \\
\text { - Levar em conta o previsto na } \\
\text { norma ABNT NBR ISO 9826:2008 } \\
\text { para correto dimensionamento; } \\
\text { - se estiver em regime de afoga- } \\
\text { mento, devem ser feitas duas leitu- } \\
\text { ras de nível e correção da fórmula } \\
\text { de cálculo. }\end{array}$ \\
\hline
\end{tabular}




\begin{tabular}{|c|c|c|c|c|c|}
\hline Equipamento & Funcionamento & Preço & Vantagens & Desvantagens & Recomendações gerais \\
\hline $\begin{array}{l}\text { 10. Ultrassônico de va- } \\
\text { zão por efeito Doppler }\end{array}$ & $\begin{array}{l}\text { - Vazão calculada pela medição da } \\
\text { velocidade média na seção através } \\
\text { dos ecos dos pulsos de ultrassom que } \\
\text { o sensor emite para o receptor do pró- } \\
\text { prio instrumento; } \\
\text { Os pulsos são refletidos em pequenas } \\
\text { bolhas de ar e/ou sólidos presente na } \\
\text { água bruta. }\end{array}$ & $\mathrm{R} \$ 30.000-33.000$ & $\begin{array}{l}\text { - Instalação rápida: } \\
\text { fluxo interrompido ou } \\
\text { desviado somente para } \\
\text { fixação do elemento; } \\
\text { - Calcula a vazão de } \\
\text { forma integralizada, sem } \\
\text { necessidade de disposi- } \\
\text { tivo auxiliar para medi- } \\
\text { ção de nível, como é o } \\
\text { caso do vertedouro e da } \\
\text { Calha Parshall. }\end{array}$ & $\begin{array}{l}\text { - Maior custo inicial } \\
\text { para aquisição; } \\
\text { - Instalação: feita por } \\
\text { profissional especia- } \\
\text { lizado para calibra- } \\
\text { ção e testes; } \\
\text { - Maior oscilação das } \\
\text { vazões instantâneas: } \\
\text { presença de partícu- } \\
\text { las sólidas e bolhas } \\
\text { de ar, apresentando } \\
\text { maior desvio padrão } \\
\text { nas medições; } \\
\text { - Necessita manuten- } \\
\text { ção periódica: con- } \\
\text { tato direto com a } \\
\text { água }\end{array}$ & $\begin{array}{l}\text { - Deve-se atentar para manutenção } \\
\text { periódica, a depender a qualidade } \\
\text { da água e da presença de vegetais } \\
\text { que passam pelo canal, que pode } \\
\text { acarretar problemas quanto à lei- } \\
\text { tura, pelo acúmulo gradual de } \\
\text { limbo no elemento sensor do equi- } \\
\text { pamento, por estar instalado em } \\
\text { contato direto com a água. }\end{array}$ \\
\hline $\begin{array}{l}\text { 11. Transmissor de ní- } \\
\text { vel por pressão hidros- } \\
\text { tática }\end{array}$ & $\begin{array}{l}\text { Os sensores hidrostáticos medem o } \\
\text { nível d'água pela pressão da coluna } \\
\text { de água, podendo o sensor estar dire- } \\
\text { tamente submerso ou acoplado exter- } \\
\text { namente. }\end{array}$ & $\mathrm{R} \$ 3.000-3.500$ & $\begin{array}{l}\text { - Preço menor, se com- } \\
\text { parado com ultrassônico } \\
\text { de nível; }\end{array}$ & $\begin{array}{l}\text { - Requer manutenção } \\
\text { periódica, por estar } \\
\text { em contato direto } \\
\text { com o meio líquido; } \\
\text { - Mais sensível a } \\
\text { problemas elétricos, } \\
\text { e de surtos por des- } \\
\text { carga atmosférica, } \\
\text { por estar no meio lí- } \\
\text { quido. }\end{array}$ & $\begin{array}{l}\text { - Deve-se atentar para manutenção } \\
\text { periódica, a depender a qualidade } \\
\text { da água e da presença de vegetais } \\
\text { que passam pelo canal, que pode } \\
\text { acarretar problemas quanto à lei- } \\
\text { tura, pelo acúmulo gradual de } \\
\text { limbo no sensor hidrostático, por } \\
\text { estar instalado em contato direto } \\
\text { com a água. }\end{array}$ \\
\hline $\begin{array}{l}\text { 12. Transmissor de ní- } \\
\text { vel ultrassônico }\end{array}$ & $\begin{array}{l}\text { Envia e recebe ondas ultrassônicas } \\
\text { que são refletidas quando tocam a su- } \\
\text { perfície da água }\end{array}$ & $R \$ 4.000-4.500$ & $\begin{array}{l}\text { - Maior precisão: erro } \\
\text { varia } \pm 0,5 \% \\
\text { - Não requer manuten- } \\
\text { ção, por não ter contato } \\
\text { com o meio líquido }\end{array}$ & $\begin{array}{l}\text { - Preço menor, se } \\
\text { comparado com sen- } \\
\text { sor hidrostático. }\end{array}$ & $\begin{array}{l}\text { - Instalação deve ser feita por pro- } \\
\text { fissional para calibração da altura } \\
\text { de medida. }\end{array}$ \\
\hline
\end{tabular}


Tabela D.3 - Tabela resumo dos dispositivos acumuladores de tempo

\begin{tabular}{|c|c|c|c|c|c|}
\hline Dispositivo & Funcionamento & Preço & Vantagens & Desvantagens & Recomendações gerais \\
\hline $57745^{\text {SEE }}$ & $\begin{array}{l}\text { - Contato seco instalado junto à chave } \\
\text { de partida do conjunto motobomba; } \\
\text { - A contagem de tempo está associ- } \\
\text { ada à energia, ao funcionamento do } \\
\text { motor. }\end{array}$ & $\mathrm{R} \$ 350-1.000$ & $\begin{array}{l}\text { - Preço acessível para } \\
\text { aquisição; } \\
\text { - Não há necessidade de } \\
\text { técnico especializado } \\
\text { para instalação; } \\
\text { - Não há custo de manu- } \\
\text { tenção. }\end{array}$ & $\begin{array}{l}\text { - Não mede vazão: } \\
\text { somente acumula o } \\
\text { tempo de funciona- } \\
\text { mento; } \\
\text { Instalações em para- } \\
\text { lelo: um horímetro } \\
\text { para cada conjunto } \\
\text { motor-bomba; } \\
\text { - Não funciona para } \\
\text { captação com motor } \\
\text { a diesel. }\end{array}$ & $\begin{array}{l}\text { - Em empreendimentos onde é ne- } \\
\text { cessária a medição de vazão e a to- } \\
\text { talização do volume, pode ser utili- } \\
\text { zado como auxiliar a um equipa- } \\
\text { mento principal, como acumulador } \\
\text { do tempo. Entretanto, por não me- } \\
\text { dir vazão, não deve ser utilizado } \\
\text { como dispositivo único. }\end{array}$ \\
\hline 2. Chave de fluxo & $\begin{array}{l}\text { - A chave de fluxo mais comum no } \\
\text { mercado é a do tipo palheta. } \\
\text { - Sistema mecânico de acionamento, } \\
\text { com haste e palheta de metal. Detecta } \\
\text { a presença de fluxo no interior do } \\
\text { tubo ao se opor ao seu movimento. } \\
\text { - A contagem de tempo está associ- } \\
\text { ada ao fluxo de água que passa pela } \\
\text { tubulação, não à energia. }\end{array}$ & $\mathrm{R} \$ 550-2.500$ & $\begin{array}{l}\text { - Está ligado ao fluxo, } \\
\text { instalada diretamente na } \\
\text { tubulação, não depende } \\
\text { de energia; } \\
\text {-Preço acessível para } \\
\text { instalação. }\end{array}$ & $\begin{array}{l}\text { - Mais caro que o ho- } \\
\text { rímetro; } \\
\text { - Necessidade de } \\
\text { furo no tubo para } \\
\text { instalação; } \\
\text { - Instalada por pro- } \\
\text { fissional especiali- } \\
\text { zado; } \\
\text { - Água bruta com só- } \\
\text { lidos em suspensão: } \\
\text { mau funcionamento. }\end{array}$ & $\begin{array}{l}\text { - Manutenção periódica para água } \\
\text { bruta, a fim de evitar que a palheta } \\
\text { fique emperrada pela presença de } \\
\text { sólidos. }\end{array}$ \\
\hline
\end{tabular}

